Prepared in cooperation with the National Park Service

\title{
Streambank Erosion and Related Geomorphic Change in Tuolumne Meadows, Yosemite National Park, California
}

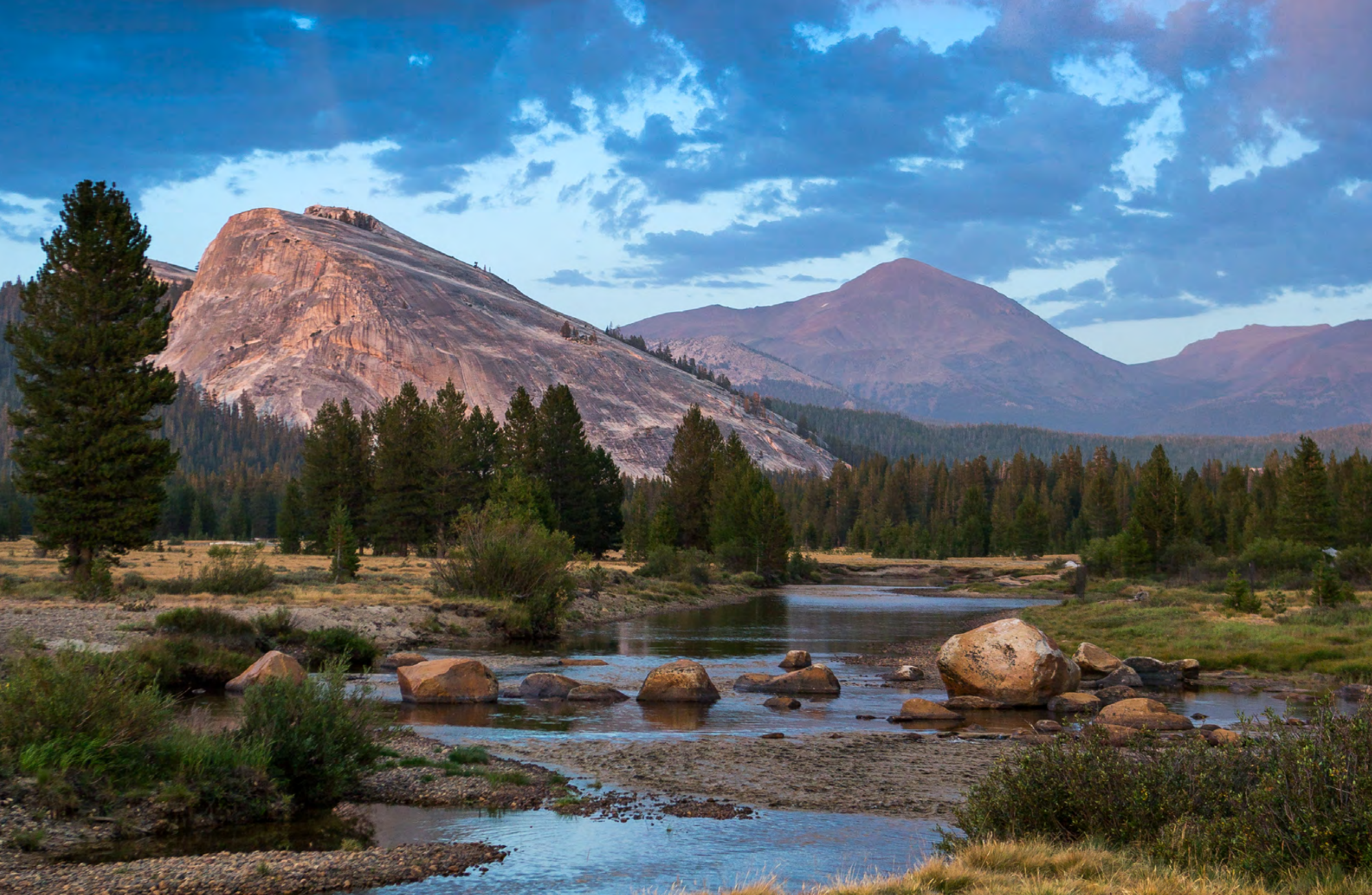

Scientific Investigations Report 2021-5025

U.S. Department of the Interior U.S. Geological Survey 
Front Cover. Photograph of Tuolumne River in Tuolumne Meadows, California, looking east from erosion zone 5 as defined in this report with Lembert Dome and Mount Gibbs visible in the background . Photograph by Ryan Alonzo, titled Tuolumne Virga, used with permission.

Back cover. (1) U.S. Geological Survey photograph of the Tuolumne River in Tuolumne Meadows, California, looking southeast from just west of erosion zone 5 as defined in this report with Mammoth Peak visible in the background. (2) U.S. Geological Survey photograph of the Tuolumne River in Tuolumne Meadows, California, looking west from erosion zone 7 as defined in this report with Pothole Dome and Fairview Dome visible in the background. 


\section{Streambank Erosion and Related Geomorphic Change in Tuolumne Meadows, Yosemite National Park, California}

By Stephen B. DeLong, Alexandra J. Pickering, and Timothy Kuhn

Prepared in cooperation with the National Park Service

Scientific Investigations Report 2021-5025 


\section{U.S. Geological Survey, Reston, Virginia: 2021}

For more information on the USGS — the Federal source for science about the Earth, its natural and living resources, natural hazards, and the environment—visit https://www.usgs.gov or call 1-888-ASK-USGS (1-888-275-8747).

For an overview of USGS information products, including maps, imagery, and publications, visit https://store.usgs.gov.

Any use of trade, firm, or product names is for descriptive purposes only and does not imply endorsement by the U.S. Government.

Although this information product, for the most part, is in the public domain, it also may contain copyrighted materials as noted in the text. Permission to reproduce copyrighted items must be secured from the copyright owner.

Suggested citation:

DeLong, S.B., Pickering, A.J., and Kuhn, T., 2021, Streambank erosion and related geomorphic change in Tuolumne Meadows, Yosemite National Park, California: U.S. Geological Survey Scientific Investigations Report 2021-5025, 87 p., https://doi.org/10.3133/sir20215025.

ISSN 2328-0328 (online) 


\section{Preface}

Tuolumne Meadows, in the high country of Yosemite National Park, California, is a renowned natural and recreational resource noted for its scenic beauty, wildlife, and as a place of peace and tranquility. It attracts large numbers of visitors from around the world, and its importance is recognized by its designation as part of the Tuolumne Wild and Scenic River Final Comprehensive Management Plan. In keeping with this designation, management decisions are made with respect to biologic, geologic, cultural, scenic and recreational values with the purpose of preserving the Tuolumne River in free-flowing conditions, and to protect water quality. Part of the management plan is to monitor streambank dynamics in Tuolumne Meadows and to make science-based decisions regarding management and restoration efforts. This report provides scientific information towards these objectives.

\section{Acknowledgments}

The National Park Service (NPS) funded, collaborated on, and provided logistical support for this project. The National Center for Airborne Laser Mapping and Greg Stock, NPS, were responsible for the 2006 airborne laser swath mapping data, and OpenTopography which hosts and serves the data to users. Kyle Juracek and Matthew Cashman provided very helpful and detailed reviews of this report. Joseph Mason, William Otto, Nikita Avdievitch, Zachary Engle, and Sally Keating provided field assistance. Jan van Wagtendonk and Peggy Moore facilitated use of the U.S. Geological Survey research cabin in Yosemite National Park. Harrison Forrester provided logistical support in Yosemite National Park. Zachary Engle assisted with figures. Rachel Hallnan provided updated streamflow data. 


\section{Contents}

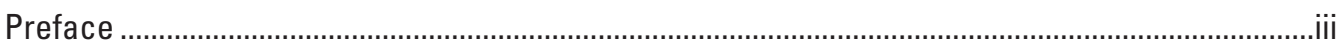

Acknowledgments ...........................................................................................................ii

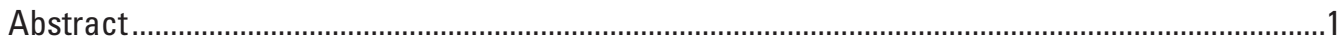

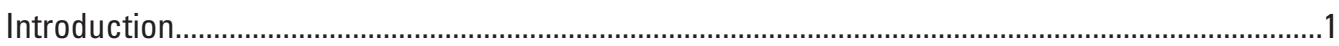

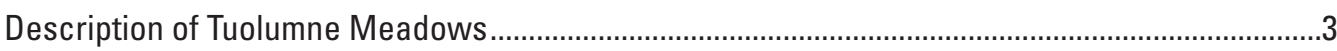

Methods

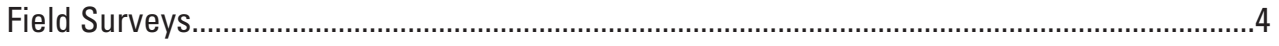

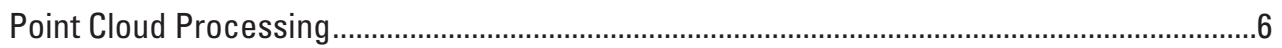

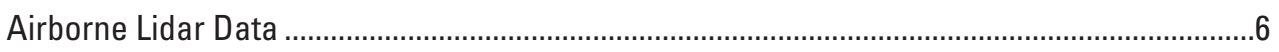

Generation of Derivative Products from Lidar Point Clouds.......................................................6

Landscape Change Mapping ..............................................................................................

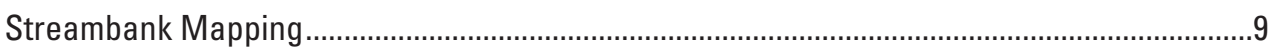

Empirical Error Estimate Refinement Using Stable Landscape Areas ...................................10

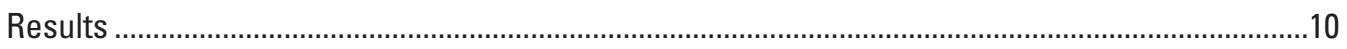

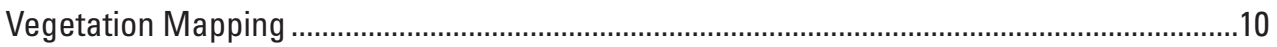

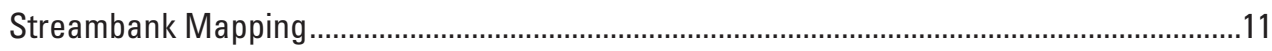

Zones of Active Streambank Migration and Landscape Change .........................................11

Details of Landscape Change at Erosion Zones ...................................................................13

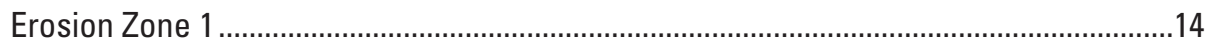

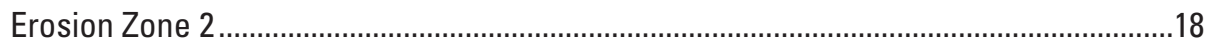

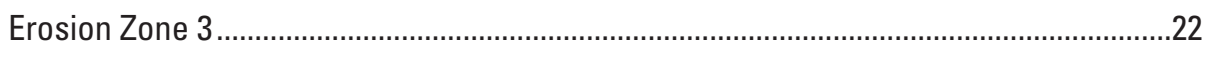

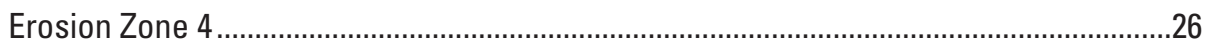

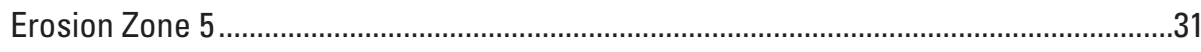

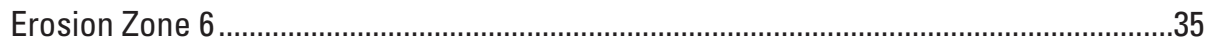

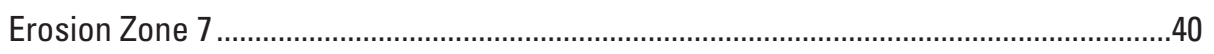

Erosion Zone 8

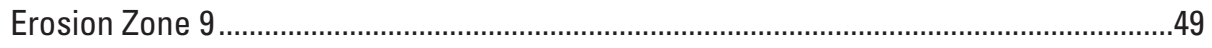

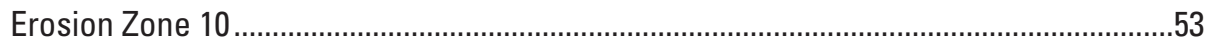

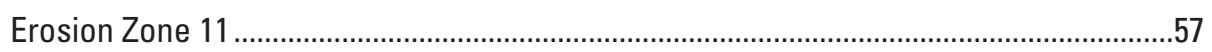

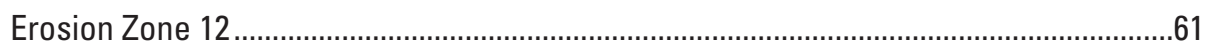

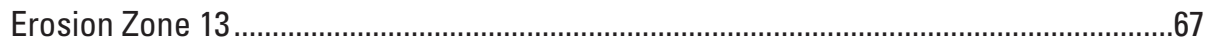

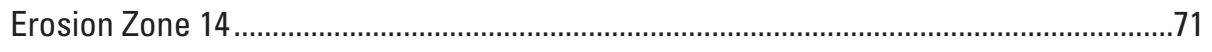

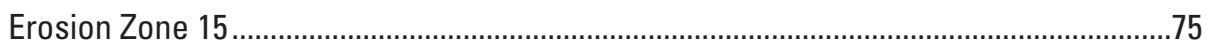

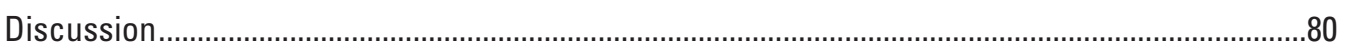

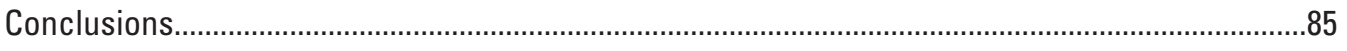

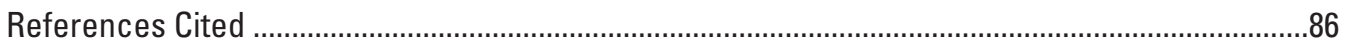




\section{Figures}

1. Map of Tuolumne Meadows in Yosemite National Park, California, USA ...........................2

2. Maps of Tuolumne Meadows study area ...........................................................................

3. Slopeshade maps made from terrestrial laser scanner data of the study area from 2016-2018.

4. Maps of vegetation canopy height in Tuolumne Meadows derived from 2006 airborne laser swath mapping and 2018 terrestrial laser scanning..................................7

5. Map of streambank willows and short vegetation along Tuolumne River derived from 2018 terrestrial laser scanning point clouds ...............................................................

6. Map of indistinct/stable and steep/active areas along the Tuolumne River .....................9

7. Maps depicting elevation changes from 2006 to 2018 in Tuolumne Meadows................12

8. Map of polygons used to extract erosion and deposition volumes along the Tuolumne River.

9. Lidar-derived maps showing location and classification of stream banks at

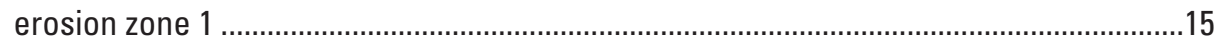

10. Lidar-derived maps of vegetation at erosion zone 1....................................................17

11. Photographs of erosion zone 1 in 2016

12. Lidar-derived maps showing location and classification of stream banks at

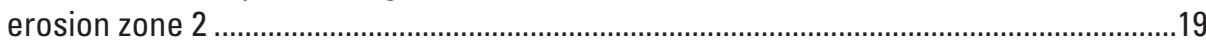

13. Lidar-derived maps of vegetation at erosion zone 2..................................................21

14. Lidar-derived maps showing location and classification of stream banks at

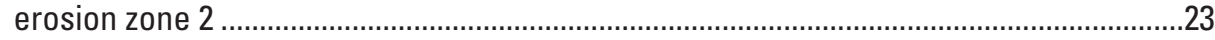

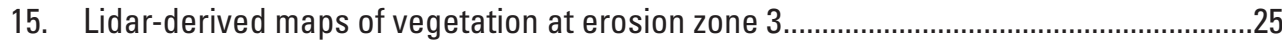

16. Photographs of erosion zone 3 in 2016

17. Lidar-derived maps showing location and classification of stream banks at

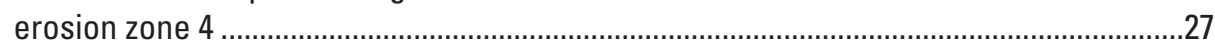

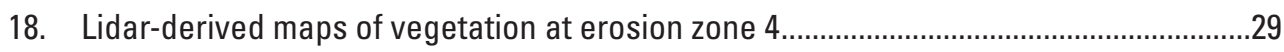

19. Photographs of erosion zone 4, 2016-2018 ............................................................30

20. Lidar-derived maps showing location and classification of stream banks at

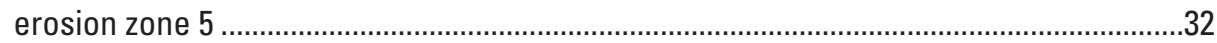

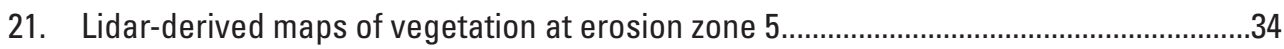

22. Photographs of erosion zone 5 in 2016 and 2017 ......................................................35

23. Lidar-derived maps showing location and classification of stream banks at erosion zone 6 ............................................................................................................

24. Lidar-derived maps of vegetation at erosion zone 6 .......................................................38

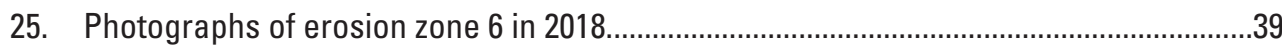

26. Lidar-derived maps showing location and classification of stream banks at

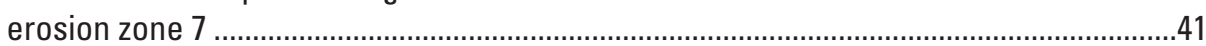

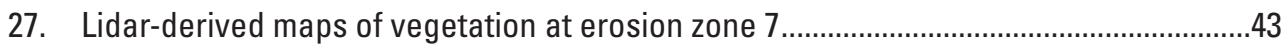

28. Photographs of erosion zone 7 in 2016 and 2018 ......................................................

29. Lidar-derived maps showing location and classification of stream banks at

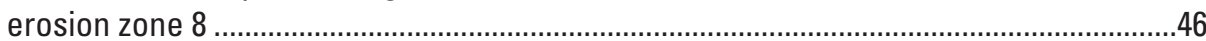

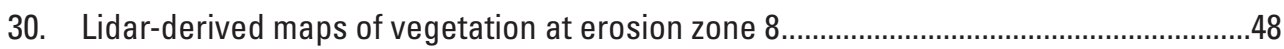

31. Photographs of erosion zone 8 in 2016 .................................................................

32. Lidar-derived maps showing location and classification of stream banks at erosion zone 9 


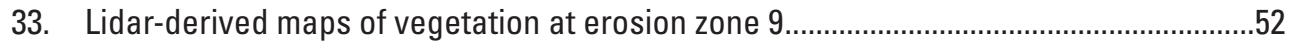

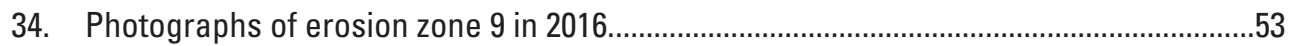

35. Lidar-derived maps showing location and classification of stream banks at

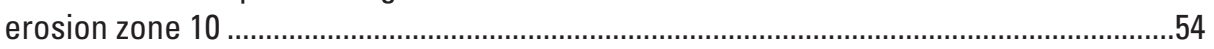

36. Lidar-derived maps of vegetation at erosion zone 10...............................................56

37. Photographs of erosion zone 10 in 2016 ...................................................................

38. Lidar-derived maps showing location and classification of stream banks at

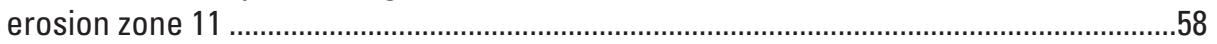

39. Lidar-derived maps of vegetation at erosion zone 11...............................................60

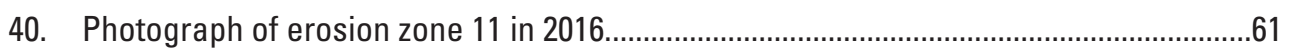

41. Lidar-derived maps showing location and classification of stream banks at erosion zone 12

42. Lidar-derived maps of vegetation at erosion zone 12 .................................................64

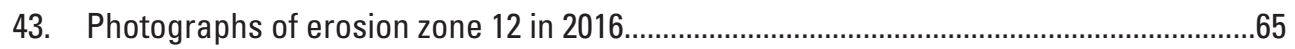

44. Lidar-derived maps showing location and classification of stream banks in

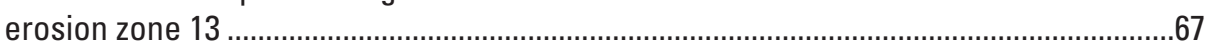

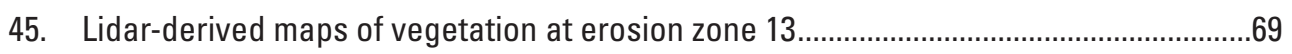

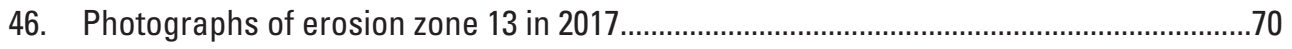

47. Lidar-derived maps showing location and classification of stream banks at erosion zone 14

48. Lidar-derived maps of vegetation at erosion zone 14.....................................................

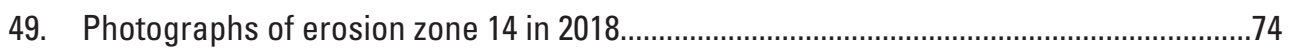

50. Lidar-derived maps showing location and classification of stream banks at

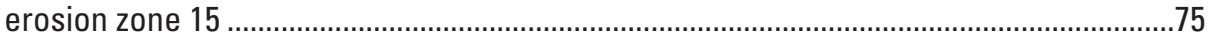

51. Lidar-derived maps of vegetation at erosion zone 15....................................................77

52. Photographs of erosion zone 15 in 2018 ……………............................................

53. Graph of streambank volumetric change rate versus sinuosity along the Tuolumne River channel measured at eroding streambanks ..........................................................82

54. Graph of streambank retreat rate versus sinuosity along the Tuolumne River

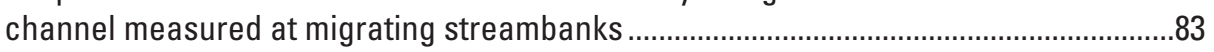

55. Graph of streambank volumetric change rate (from mapping) versus sinuosity along the Tuolumne River channel .....

56. Graph of stream discharge along the Tuolumne River upstream of Tuolumne Meadows at gage "TUM" from 2006 to 2018 


\section{Tables}

1. Lidar point cloud data used in this study.....

2. Indication of vertical accuracy of DEMs of difference (DoDs) using apparently stable areas including highway, gravel roads, gravel hiking trails, and natural bedrock outcrops.

3. Estimates of erosion and deposition at erosion zone 1 along Tuolumne River ................14

4. Estimates of erosion and deposition at erosion zone 2 along Tuolumne River ................22

5. Estimates of erosion and deposition at erosion zone 3 along Tuolumne River ................22

6. Estimates of erosion and deposition at erosion zone 4 along Tuolumne River .................26

7. Estimates of erosion and deposition at erosion zone 5 along Tuolumne River .................31

8. Estimates of erosion and deposition at erosion zone 6 along Tuolumne River ................39

9. Estimates of erosion and deposition at erosion zone 7 along Tuolumne River .................40

10. Estimates of erosion and deposition at erosion zone 8 along Tuolumne River ................45

11. Estimates of erosion and deposition at erosion zone 9 along Tuolumne River ................49

12. Estimates of erosion and deposition at erosion zone 10 along Tuolumne River ..............53

13. Estimates of erosion and deposition at erosion zone 11 along Tuolumne River ..............61

14. Estimates of erosion and deposition at erosion zone 12 along Tuolumne River ..............66

15. Estimates of erosion and deposition at erosion zone 13 along Tuolumne River ...............70

16. Estimates of erosion and deposition at erosion zone 14 along Tuolumne River ..............74

17. Estimates of erosion and deposition at erosion zone 15 along Tuolumne River ..............78

18. Rates of erosion at streambanks along Tuolumne River....................................................79

19. Rates of sediment deposition on point and channel bars opposite eroding streambanks along Tuolumne River ................................................................................8

20. Net volumetric change along entire surveyed reach of the Tuolumne River...................81

21. Sinuosity at zones of streambank erosion along Tuolumne River...................................82

\section{Conversion Factors}

International System of Units to U.S. customary units

\begin{tabular}{lll}
\hline \multicolumn{1}{c}{ Multiply } & By & \multicolumn{1}{c}{ To obtain } \\
\hline centimeter $(\mathrm{cm})$ & Length & \\
meter $(\mathrm{m})$ & 0.3937 & inch (in.) \\
kilometer $(\mathrm{km})$ & 3.281 & mile $(\mathrm{mi})$ \\
meter $(\mathrm{m})$ & 0.6214 & yard $(\mathrm{yd})$ \\
\hline & 1.094 & \\
\hline hectare $(\mathrm{ha})$ & Area & acre \\
hectare $(\mathrm{ha})$ & 2.471 & square mile $\left(\mathrm{mi}^{2}\right)$ \\
\hline & 0.003861 & \\
\hline cubic meter per year $\left(\mathrm{m}^{3} / \mathrm{yr}\right)$ & Flow rate & acre-foot per year $(\mathrm{acre}-\mathrm{ft} / \mathrm{yr})$ \\
\hline
\end{tabular}




\section{Datum}

Vertical coordinate information is referenced to the WGS84 Ellipsoid.

Horizontal coordinate information is referenced to the North American Datum of 1983 (NAD 83).

\section{Abbreviations}

$3 \mathrm{D}$

ALSM

DEM

DoD

GPS

LoD

NCALM

TLS three dimensional

Airborne laser swath mapping

Digital elevation model

DEMs of difference

Global Positioning System

level of detection

National Center for Airborne Laser Mapping

Terrestrial laser scanning 


\title{
Streambank Erosion and Related Geomorphic Change in Tuolumne Meadows, Yosemite National Park, California
}

\author{
By Stephen B. DeLong ${ }^{1}$, Alexandra J. Pickering ${ }^{1}$, and Timothy Kuhn ${ }^{2}$
}

\section{Abstract}

Landscape change in Tuolumne Meadows, Yosemite National Park, California, was characterized using data derived from four lidar surveys: one airborne survey in 2006 and three terrestrial surveys in 2016, 2017, and 2018. These surveys were used to generate a better quantitative understanding of changes associated with fluvial processes along the reach of the Tuolumne River within Tuolumne Meadows. This research was performed to provide a scientific basis for restoration and management decisions made by the National Park Service in accordance with the Tuolumne Wild and Scenic River Final Comprehensive Management Plan. A total of 15 reaches of the streambanks along the Tuolumne River in Tuolumne Meadows were subject to measurable streambank erosion between 2006 and 2018. In these areas, streambank retreat rates ranged between 0 and 2.7 meters per year $(\mathrm{m} / \mathrm{yr})$, recorded as an average retreat distance along the length of changing streambank position, with most retreat rates being less than $0.50 \mathrm{~m} / \mathrm{yr}$. The highest streambank retreat rates are associated with a year of high spring streamflow in 2017. Based on the data available, it was concluded that deposition on channel and point bars balances streambank erosion over a period of 12 years along the Tuolumne River in Tuolumne Meadows. As such, the river could be considered to be in a state of dynamic equilibrium during this period; erosion and sedimentation occur in distinct pulses in response to hydrological forcing but it is not clear that there is a trend towards sediment accumulation or removal in Tuolumne Meadows nor is there an obvious trend toward channel widening or narrowing. The existence of visible paleochannels in the meadow are an indication that more dramatic channel planform geometry changes have occurred in Tuolumne Meadows over an undetermined period and may occur again in the future. Geomorphic change rates relate to hydrology; during the study period, the high water in 2017 led to the highest rates of geomorphic change. Land managers should anticipate that floods with discharge rates greater than the peak flow in 2017 may cause more substantial landscape change than what was observed in this study, but erosion resulting from these events may be balanced by channel and point-bar deposition over a period of years.

${ }^{1}$ U.S. Geological Survey.

${ }^{2}$ National Park Service.

\section{Introduction}

Tuolumne Meadows is a large subalpine meadow in the high-elevation part of Yosemite National Park, California (fig. 1). It is situated at about 2,600 meters (m) above sea level, surrounded by iconic granodiorite domes, ridges, and peaks. The meadow is a delicate ecological attraction made up of subalpine vegetation and erodible soils that have developed since glaciers receded between 17,000 and 14,000 years ago. It is a focal area for visitation to Yosemite National Park. Visitor use, historical land use, and natural processes may affect current conditions of Tuolumne Meadows. It is thought that the ecological integrity (the ability of the ecosystem to support ecological function, species diversity, and other characteristics similar to nearby ecosystems) of the meadows may be declining (Cooper and others, 2006; Buhler and others, 2010). The Tuolumne Meadows reach is within a designated "scenic" reach and is managed according to the Tuolumne Wild and Scenic River Final Comprehensive Management Plan and Environmental Impact Statement (National Park Service, 2014). This plan - herein referred to as the Tuolumne River plan — guides management of the Tuolumne River by emphasizing preservation of its free-flowing conditions, protection of water quality, and protection of its "outstanding remarkable values."

Within the framework of the Tuolumne River plan, the stability of streambanks in Tuolumne Meadows is a monitoring indicator for conditions of the subalpine meadow and riparian complex. The Tuolumne River plan recognizes that eroding streambanks are both part of a natural process but also may be a result of land-use changes to accommodate visitors and the history of vegetation change that likely occurred coincident with intense grazing from 1860 to the early 20th century (Dull, 1999). Therefore, streambank stability is considered a biological value to be monitored. Some of the relevant background language from the National Park Service (2014) follows:

Based on a preliminary condition assessment (developed by [Pritchard and others, 1998]) of the Tuolumne River in Tuolumne Meadows, a team of hydrologists and river managers determined that several reaches of the Tuolumne River appear to be "functioning at risk" with an undetermined trend. Cooper and others (2006) found that the banks of the Tuolumne River were eroding on outside meanders 


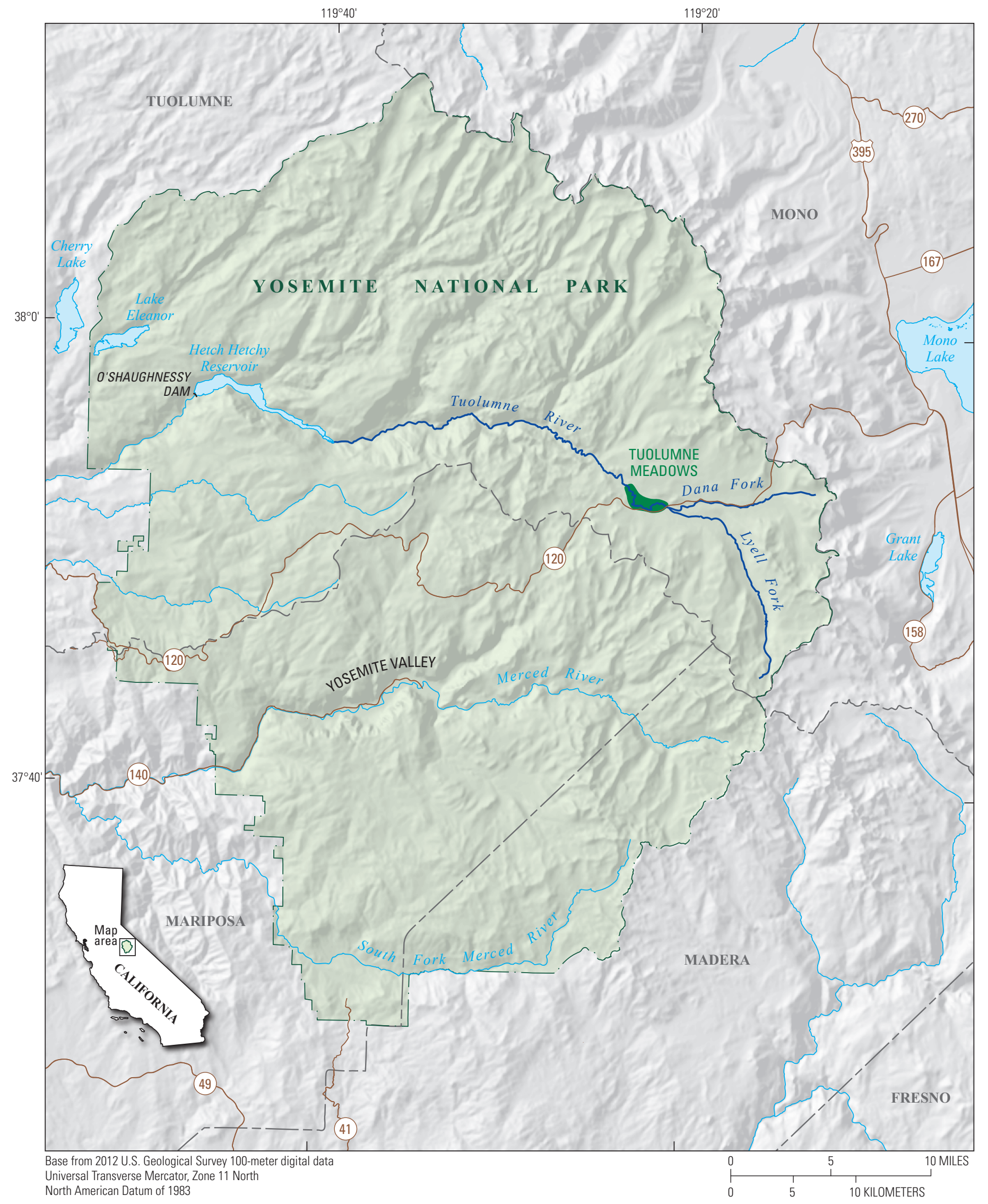

Figure 1. Map of Tuolumne Meadows in Yosemite National Park, California, USA. Darker green shape over Tuolumne Meadows is approximate study area extent. Main channels of the Tuolumne River above Hetch Hetchy Reservoir are highlighted in dark blue. 
without accompanying riparian vegetation (primarily willow) recruitment on the complementary point bar, likely resulting in channel widening. Riverside willows, abundant along the river in Tuolumne Meadows in 1867 [Cooper and others, 2006], appear to have diminished greatly. As part of the assessment of historical and contemporary influences on vegetation, Cooper and others [2006] found that the decrease in willows might be associated with extensive sheep grazing during the late 1800 s, exacerbated by deer heavily browsing the few remaining willows.

The riverbanks on the Tuolumne River (particularly on the west end of Tuolumne Meadows) have little to no vegetation, particularly willows, and are characterized by extensive erosion and riverbank loss [Buhler and others, 2010]. Vegetation loss and the subsequent riverbank erosion could be exacerbated by human trampling [Buhler and others, 2010]. Certain reaches of the Tuolumne River that experience high levels of visitor use are devoid of riverbank vegetation.

Willows along the riverbank serve an important role in preventing river widening. The lack of willows on sandbars and riverbanks allows water to flow unimpeded, thus increasing the river flow velocity and altering scour and deposition relationships [Buhler and others, 2010]. Channel widening produces a shallower channel with a lower river stage for any given flow volume and a concurrent drop of the water table associated with the river [Cooper and others, 2006; Loheide and Booth, 2011]. Because wet meadows form where a shallow water table during the summer fulfills the water requirements of this groundwaterdependent ecosystem [Loheide and others, 2009], a drop in the water table could adversely affect wet meadow vegetation. A wider, shallower channel also influences the magnitude and frequency of overbank flow and associated sheetflow processes [Buhler and others, 2010].

Though the Tuolumne River plan implies that channel bank erosion is a largely undesirable phenomenon, recent research also highlights the ecological benefits that can be derived from channel migration (for example, Williams and others, 2020). The objectives of this study are to document landscape conditions, estimate changes in streambank position, quantify erosion and deposition, and to generate ancillary data such as the location and type of riparian vegetation that may be useful as future management decisions are implemented. Data used in this study include three years of ground-based lidar surveys - herein referred to as TLS for terrestrial laser scanning - of Tuolumne Meadows completed in 2016-2018, and airborne lidar data collected in 2006-herein referred to as ALSM for airborne laser swath mapping. An analysis of streambank migration and other topographic change evident in the lidar data are presented, as is vegetation mapping derived from the three-dimensional point clouds. Several locations of streambank migration and bar deposition along the Tuolumne River in Tuolumne Meadows were identified. The collected data are available to serve as baseline data for future work (DeLong and Pickering, 2020).

Also provided are observations and interpretations that are relevant to the recent published determinations regarding conditions in Tuolumne Meadows from a geomorphic perspective. These include rates of streambank erosion and bar deposition, the relationship between streamflow and channel change, and the relationship between river planform geometry, vegetation and stream channel change.

The study potentially benefits decision-makers tasked with implementing the Tuolumne River plan, provides information that is useful for public communications relevant to river process in Tuolumne Meadows, and may motivate more direct investigation of the soils, geology, and Earthsurface processes in the study area. Tuolumne Meadows and Yosemite National Park as a whole are among the crown jewels of the United States National Park Service and the scientific data in this report are intended to support management decisions aimed at achievement of the objectives outlined in the Tuolumne River plan.

\section{Description of Tuolumne Meadows}

Tuolumne Meadows is about 2,600 $\mathrm{m}$ above sea level, just downstream of the confluence of the Dana Fork and Lyell Fork of the Tuolumne River (fig. 1). It sits between two prominent bedrock landforms: Pothole Dome on the west, and Lembert Dome on the east (fig. 2). The roughly 160-hectare meadow may owe its existence to enhanced local glacial erosion resulting from the presence of dense bedrock fractures caused by emplacement of the Johnson Granite Porphyry into the Cathedral Peak Granodiorite during the Mesozoic (Becker and others, 2014). Tuolumne Meadow is strikingly flat with only sporadic bedrock outcrops within the meadow and along the stream channel. The meadow is surrounded by classic high alpine Sierra Nevada landscape ranging from glacially scoured bare bedrock outcrops to lodgepole pine forest. The meadow elevation is controlled by an apparently resistant bedrock river channel reach at the northwest outlet of the meadow (fig. 2).

The Tuolumne River is characterized by a meandering planform geometry, a channel bed and depositional bars dominated by sand and gravel, and streambank height up to $1.4 \mathrm{~m}$. Sediments which are exposed on streambank exposures are most commonly organic-rich black fine-grained soil developed over bedded sands and gravels. Clasts up to 20 centimeters $(\mathrm{cm})$ in diameter are common in the coarsest deposits along the active Tuolumne River system. Recently deposited point bars are vegetation-free within several 


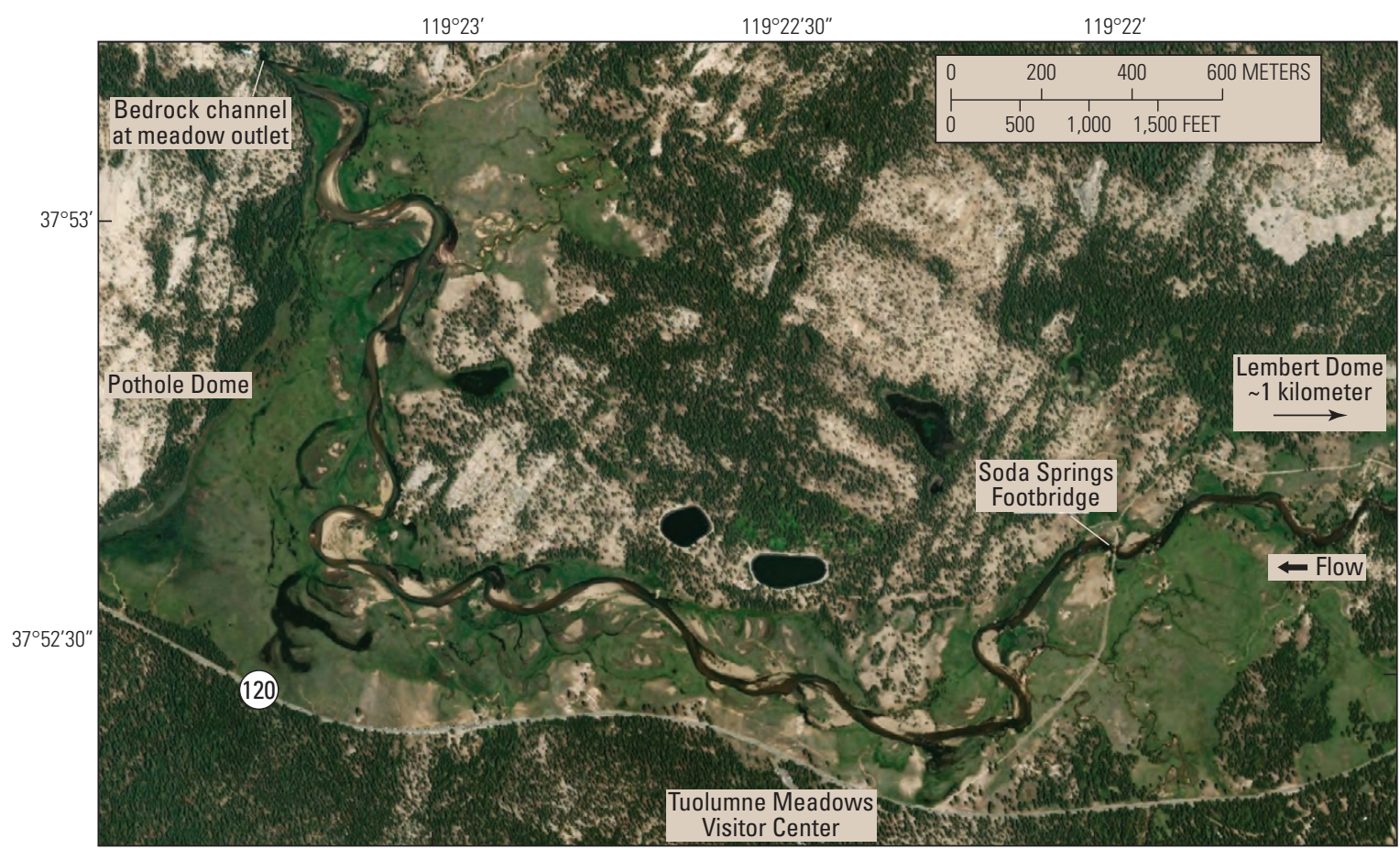

Figure 2. Maps of Tuolumne Meadows study area. Upper panel is satellite imagery of the study area. Lower panel is topography rendered from airborne laser swath mapping data of the study area. Darker colors indicate steeper slopes

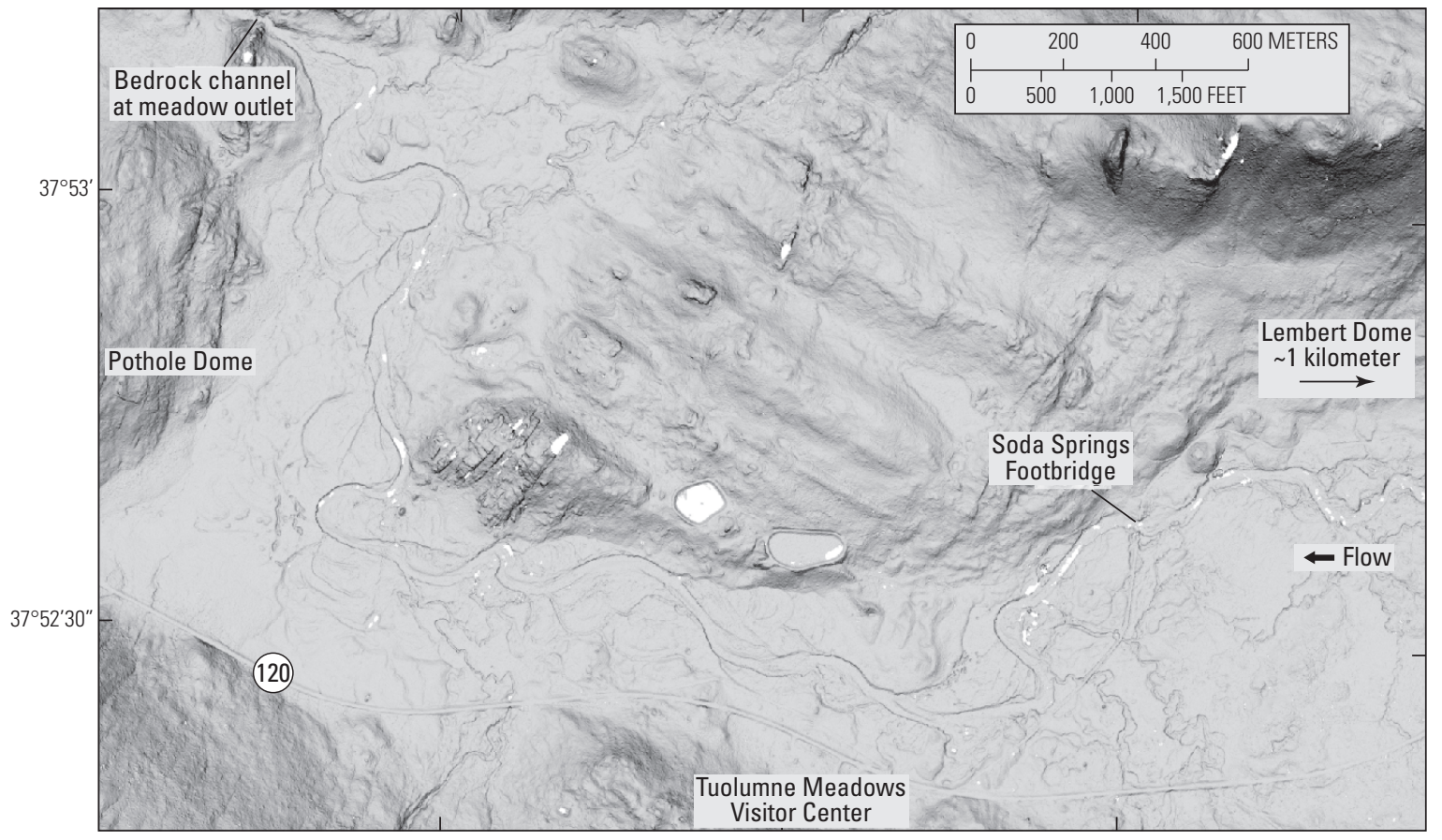

Base imagery in upper panel from ESRI/Digital Globe. Imagery in lower panel is a slopeshade/hillshade blend made from bare-earth elevation data derived from the 2006 airborne laser swath mapping (ALSM).

tens of centimeters vertically from the low-water surface elevation but are vegetated higher. The large flat expanse of Tuolumne Meadows is a mosaic of older stream channel forms, positioned 1-1.4 $\mathrm{m}$ above the low-water elevation. Runoff is mostly generated annually during snowmelt, though rainstorms do generate runoff that can lead to sudden river level changes. Winter flooding is rare owing to cold temperatures and snow accumulation, and summer flood events are very rare, though spring runoff can be delayed until June during cold years.

\section{Methods}

\section{Field Surveys}

The channel, streambanks, and meadow in Tuolumne Meadows were characterized using three-dimensional terrestrial laser scanning (TLS), this is also known as lidar (light detection and ranging). Three TLS surveys were completed in September of each year 2016-2018 (table 1). The 2016 survey covered the 
Tuolumne River from the edge of dense trees just upstream from the Soda Springs footbridge (fig. 2) downstream to the prominent bend to the north in the southwestern part of the meadow. The 2017 and 2018 surveys covered the Tuolumne River from the edge of dense trees just upstream from the Soda Springs footbridge downstream to just above the bedrock channel knickpoint (a distinct step in the river channel that forms a waterfall, caused by resistant rock) that defines the downstream end of the meadow (Bedrock channel at meadow outlet in fig. 2). Figure 3 provides the location of the scan positions for each year displayed over a blend of slopeshade (slope map in which steeper slopes are portrayed with darker colors) and hillshade (terrain shaded by artificial illumination) maps made from the bare-earth digital elevation model (DEM) for each year.

Table 1. Lidar point cloud data used in this study.

[Initial error estimates are observed errors in the accuracy of the point cloud georeferencing. ALSM, airborne laser swath mapping; TLS, terrestrial laser scanning; $\mathrm{m}$, meter; $\mathrm{km}^{2}$, square kilometers]

\begin{tabular}{|c|c|c|c|c|c|}
\hline Survey dates & Instrument & Area $\left(\mathbf{k m}^{2}\right)$ & Number of points & $\begin{array}{c}\text { Number of } \\
\text { ground points }\end{array}$ & $\begin{array}{l}\text { Initial error } \\
\text { estimate (m) }\end{array}$ \\
\hline September $18-22,2006^{1}$ & Optech 1233 ALTM (ALSM) & $\sim 7.9$ & $24,339,975$ & $6,537,774$ & 0.15 \\
\hline September $20-25,2016^{2}$ & Riegl VZ400 (TLS) & $\sim 1.4$ & $479,877,894$ & $147,223,346$ & 0.02 \\
\hline September 11-14, $2018^{2}$ & Riegl VZ400i (TLS) & $\sim 2.1$ & $754,557,695$ & $233,124,284$ & 0.05 \\
\hline
\end{tabular}

${ }^{1}$ Data collected by the National Center for Airborne Laser Mapping (NCALM) on behalf of the National Park Service (Stock, 2010).

${ }^{2}$ Data collected for this study.
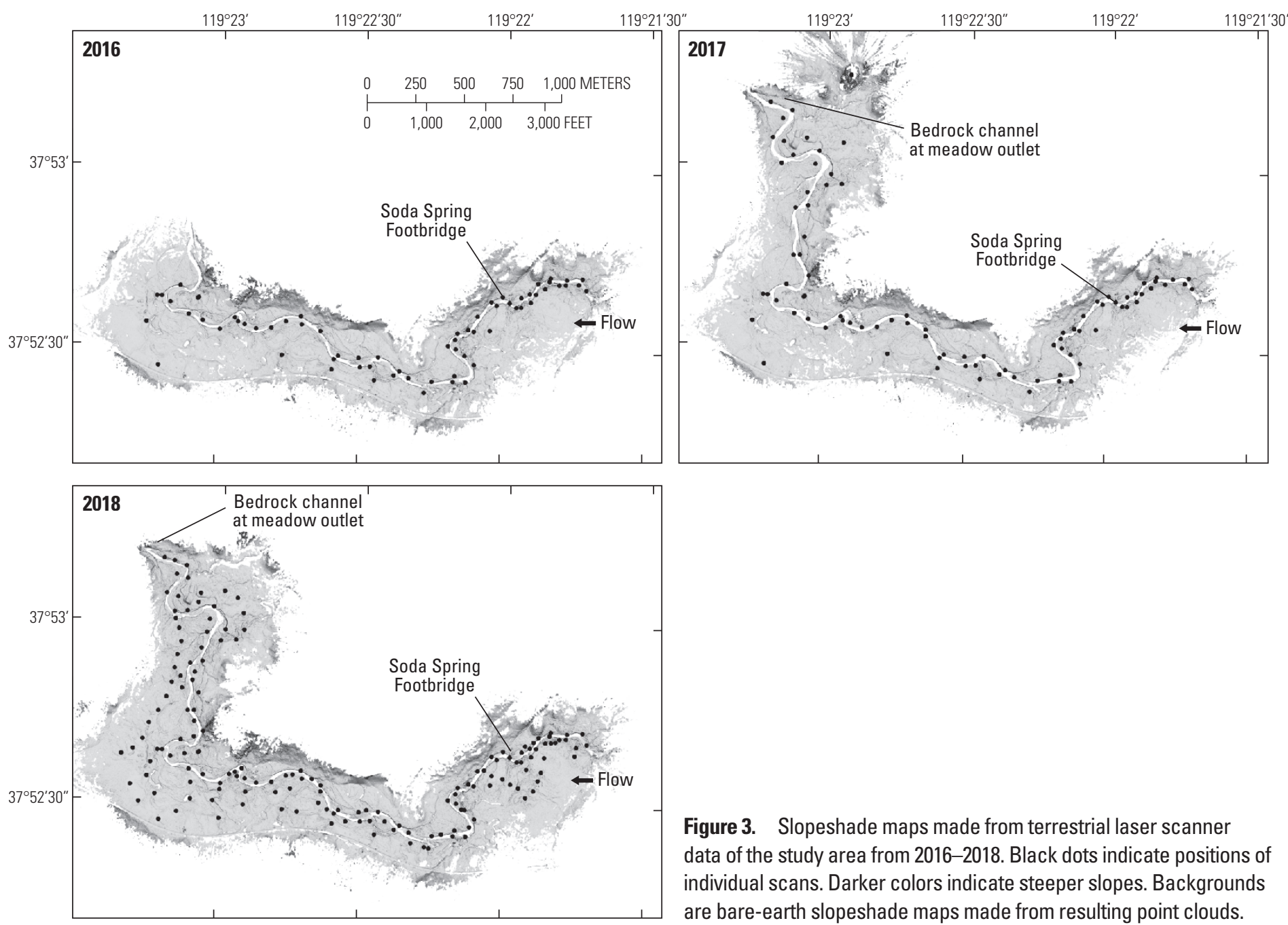

Figure 3. Slopeshade maps made from terrestrial laser scanner data of the study area from 2016-2018. Black dots indicate positions of individual scans. Darker colors indicate steeper slopes. Backgrounds are bare-earth slopeshade maps made from resulting point clouds. 
The basic principles of the survey methods employed were to collect laser scans in several positions in the meadow and along the Tuolumne River, merge these individual three-dimensional (3D) "point clouds" of XYZ coordinates and associated attribute data into a single aligned 3D point cloud and use high accuracy global positioning system (GPS) surveys to georeference the survey data into a common coordinate system. Care was taken to relocate scan positions each year, so that topographic and vegetation occlusions were consistent, minimizing spurious change-detection errors. Survey coverage expanded farther downstream along the river channel and farther out into the meadow each year from 2016 to 2018 . The resulting point clouds were filtered, classified, and gridded into derivative datasets used for the analyses presented in this report.

Specifically, in 2016 data were collected from 62 scan positions using a Riegl VZ400 laser scanner connected to a Leica Viva GS15 real-time kinematic GPS receiver. In 2017, data were collected from 98 scan positions using a Riegl VZ400i laser scanner connected to a Leica Viva GS15 real-time kinematic GPS receiver. In 2018, data were collected from 160 scan positions using a Riegl VZ400i laser scanner connected in real time to a Trimble R10 real-time kinematic GPS receiver. During each survey, several retroreflective targets set up on stable and carefully surveyed monuments were included to refine the final georeferencing. The Riegl VZ400 and VZ400i scanners differ in their speed, range, and types of orientation sensors. However, the data from these two scanners are quite similar, and all three TLS surveys were postprocessed using similar workflows: individual laser scans were oriented using an onboard electronic compass and inclinometer and georeferenced using the GPS survey data. Errors in orientation, location, and pitch were corrected using an iterative closest-point approach to minimize errors in overlapping areas between individual point clouds, as implemented in Riegl RiScan Pro software. These merged and aligned lidar point clouds had the final georeferencing refined using the surveyed targets. Errors in the accuracy of the point cloud georeferencing are estimated at less than $2 \mathrm{~cm}$ for 2016 and 2017 and $5 \mathrm{~cm}$ for 2018, when georeferencing errors were slightly higher for unknown reasons. These are reported as "initial error estimates" in table 1. Additional empirical error analysis is presented below and allows for more realistic estimation of the level of detection (LoD) of elevation change using these data. These empirical error analyses use stable landscape features and indicate these initial georeferencing error estimates are conservative. The same GPS data were used for all years for the monuments used for final georeferencing.

\section{Point Cloud Processing}

The merged, georeferenced point clouds were filtered for error points and reflections off water surfaces and were simplified using an octree approach that resulted in a point density no greater than one point for each 2.5 -cm-sized cube using Riegl RiScan Pro software. These cleaned point clouds were classified into the following classes using Terrascan software (documentation available at Terrasolid.com, accessed December 12, 2019): ground, short vegetation $(0-0.05 \mathrm{~m}$ above ground), medium vegetation (0.05-2.0 m above ground), high vegetation (2.0-100 $\mathrm{m}$ above ground), and noise.

Because the streambanks along the Tuolumne River are commonly vertical to overhanging, the classification procedure of Pack and others (2012) was modified and implemented: point clouds were tilted 50 degrees in 8 directions, ground classification was performed in each tilted position, then point clouds were rotated back to their original position and recombined. All ground points within about 5-10 $\mathrm{m}$ of the river channel edges were integrated into the final ground class, and all duplicate points were removed, retaining ground points when ground and non-ground points were co-located during the classification procedure.

\section{Airborne Lidar Data}

The ALSM data collected in September 2006 over Tuolumne Meadows (Stock, 2012) were downloaded and transformed to the same coordinate system as the TLS (NAD83(2011)) UTM zone 11 north with WGS84 ellipsoid heights. They were reclassified using Terrascan software to better characterize vegetation structure but without the use of the tilting algorithm used for the TLS because ALSM does not resolve small overhanging streambanks.

\section{Generation of Derivative Products from Lidar Point Clouds}

The classified point clouds were gridded to create derivative products that included bare-earth and full-feature digital elevation models (DEMs), slope maps, and shaded relief maps. The data are available in DeLong and Pickering (2020). From these products, canopy-height models (fig. 4) and grids of vegetation most likely to be short meadow vegetation and streambank willows were developed (fig. 5). Willow locations were characterized by identifying locations in which the vegetation canopy was between 1 and $4 \mathrm{~m}$ above ground. Most forest vegetation has canopy heights much taller than $4 \mathrm{~m}$. This method does allow for non-willow vegetation between 1 and 4 meters tall to be mischaracterized as willows, but because of the interest in riverside vegetation for erosion control, this may not be an important distinction from a geomorphic perspective. Vegetation with heights between $25 \mathrm{~cm}$ and $1 \mathrm{~m}$ were mapped from the TLS data to provide an indication of short meadow vegetation cover. It should be noted that TLS is limited in its ability to properly quantify short, dense vegetation because at longer distances and low angles from the scanner, dense vegetation obscures the soil surface, resulting in short vegetation being classified as ground. This also leads to noise in bare-earth change detection across the flat meadow regions as vegetation and scan views change from year to year. The ALSM data are quite noisy within $0.5 \mathrm{~m}$ or so of the ground surface owing to flight line overlap and sensor accuracy issues typical of data from technology at that time (2006), and are therefore less effective at mapping short vegetation. 


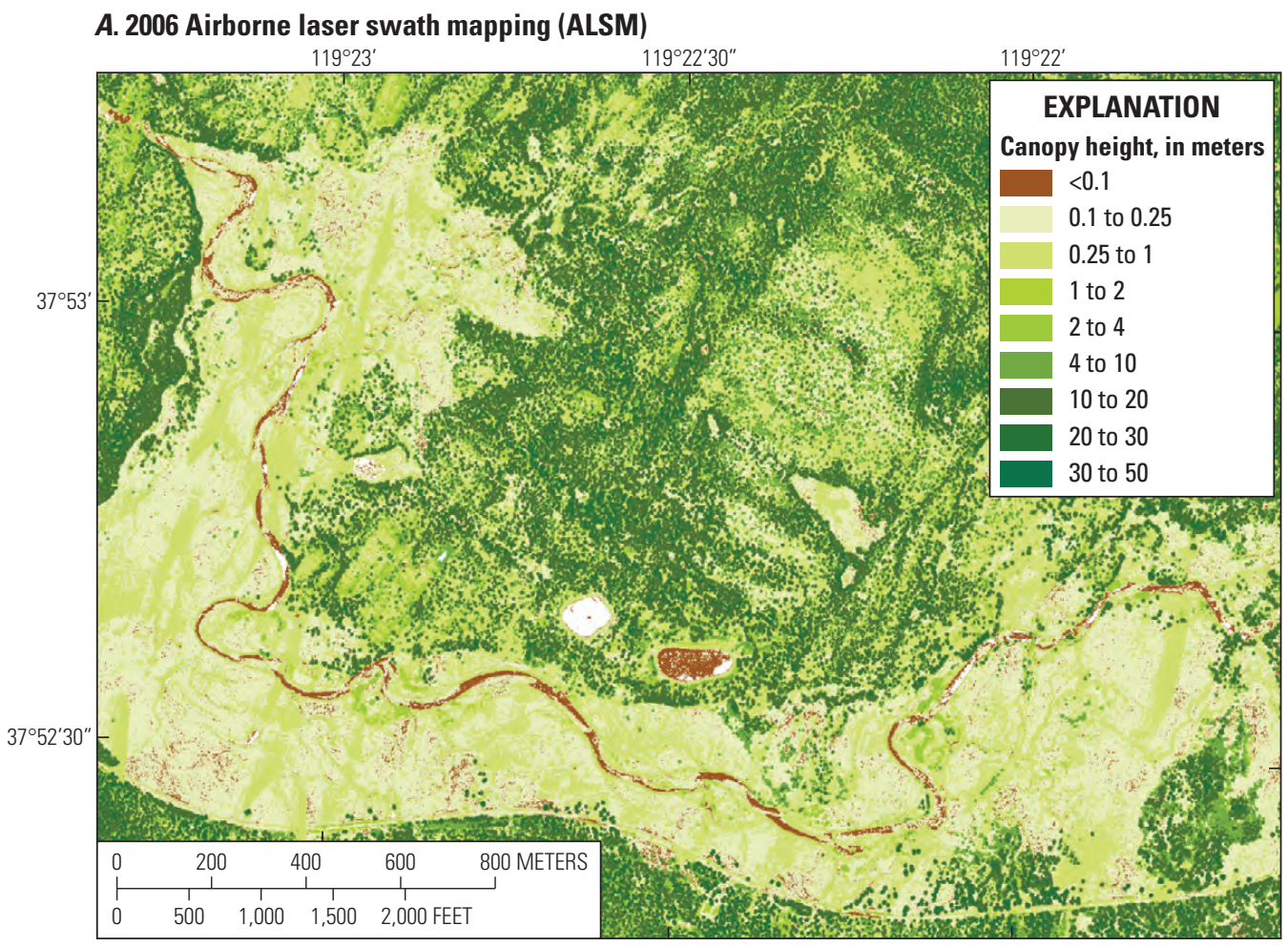

B. 2018 Terrestrial laser scanning (TLS) map

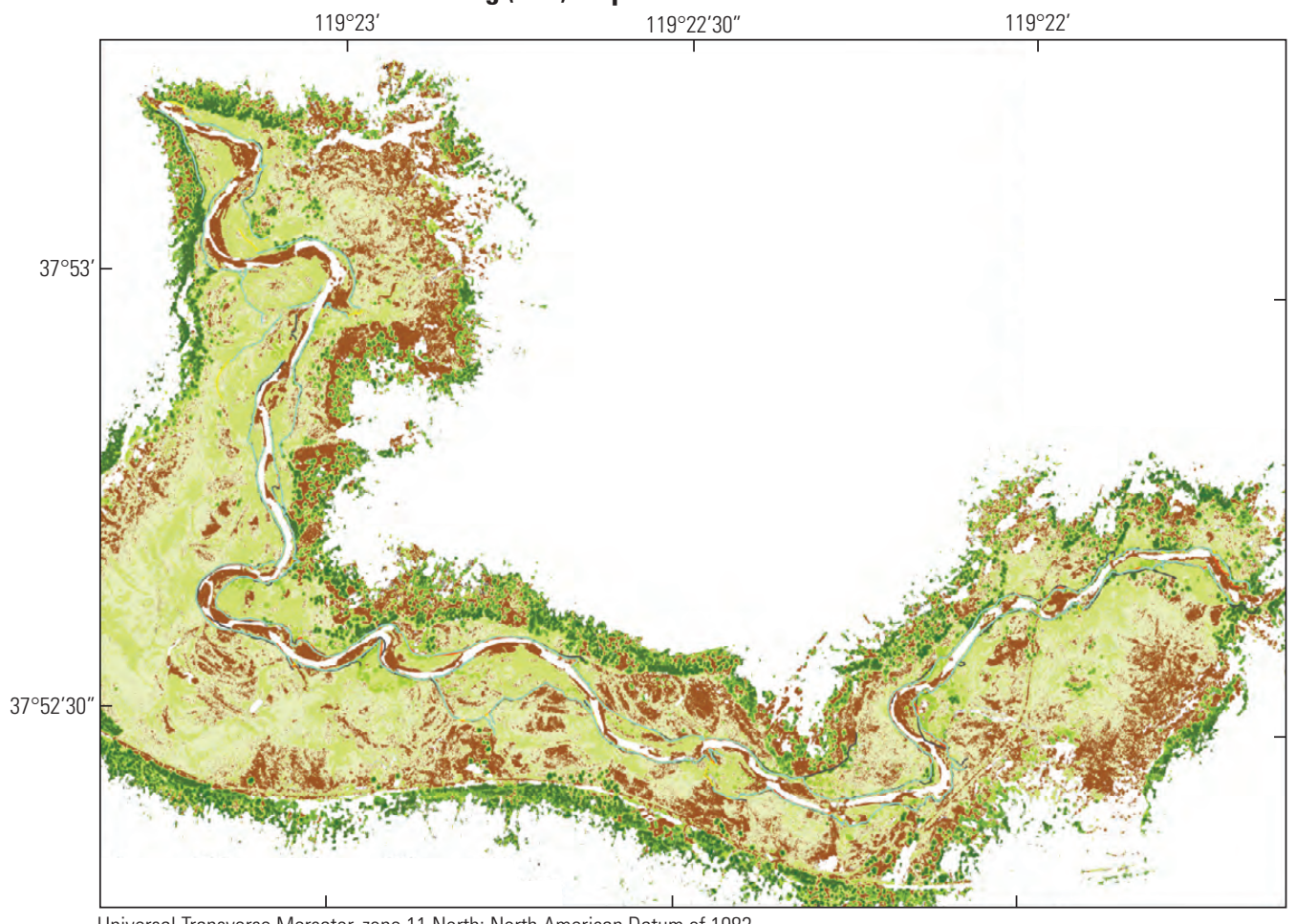

Universal Transverse Mercator, zone 11 North; North American Datum of 1983

Figure 4. Maps of vegetation canopy height in Tuolumne Meadows derived from 2006 airborne laser swath mapping (ALSM) in the upper panel $(A)$, and 2018 terrestrial laser scanning (TLS) data in the lower panel $(B)$. Note that the short vegetation derived from the 2006 ALSM exhibits some noise and NNE-SSW trending striping owing to typical flightline overlap issues (noise errors) and the presence of short meadow vegetation. Some of the $<0.1-\mathrm{m}$-tall canopy areas in the 2018 data towards the edges of the study area are owing to the low-angle-of-incidence laser pulses farthest from the laser scanner, which do not get real returns from bare ground, but rather tend to get the topmost part of vegetation instead of the ground underneath, leading areas of short vegetation far $(>\sim 100 \mathrm{~m})$ from scan positions to be misclassified as bare ground. 


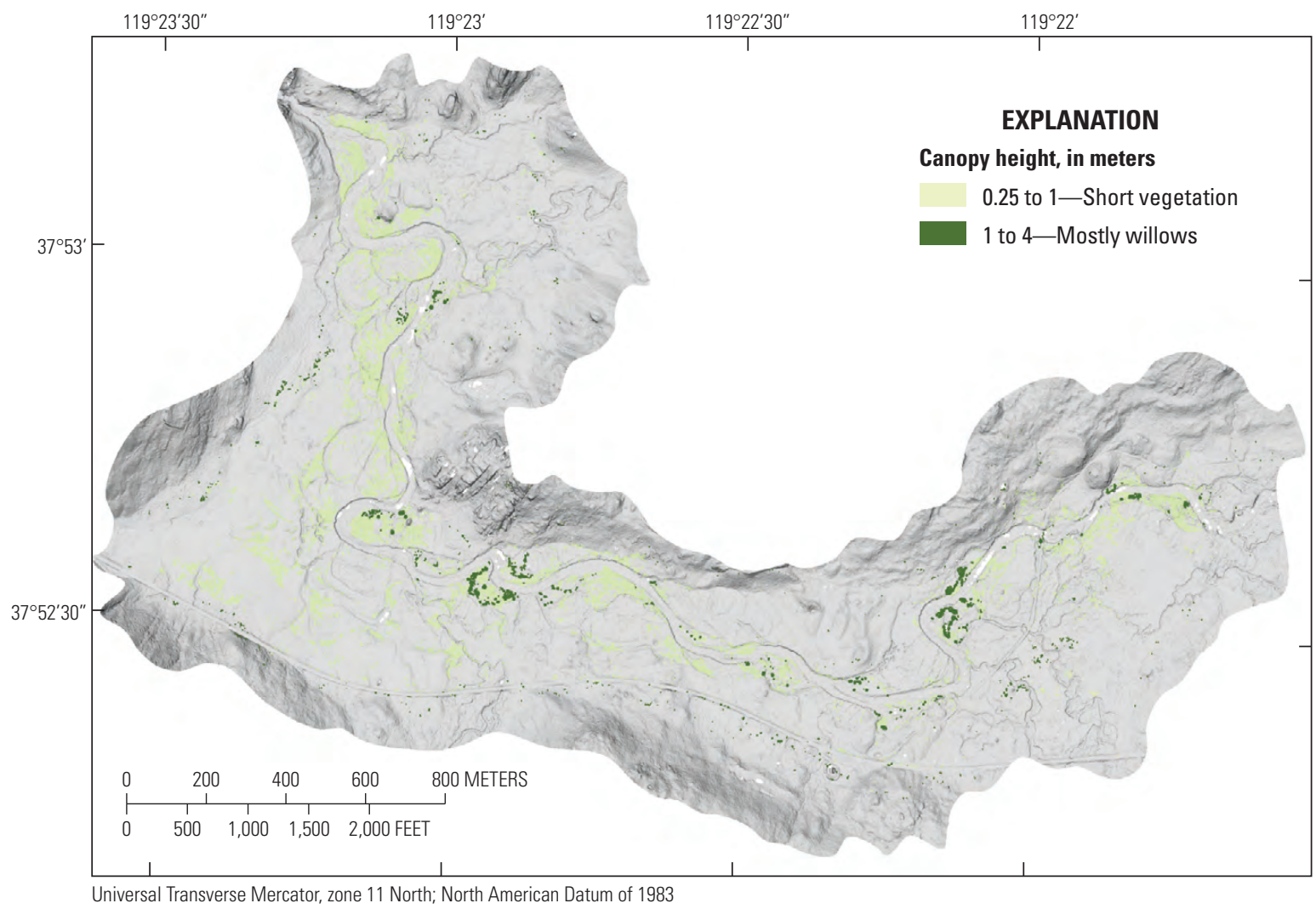

Figure 5. Map of streambank willows and short vegetation along Tuolumne River derived from 2018 terrestrial laser scanning (TLS) point clouds. Vegetation less than $1 \mathrm{~m}$ tall consists of a wide variety of meadow vegetation and possibly some young willows. Some young conifers are included in the willow mapping. In general, vegetation close to the stream channels is willows, and vegetation farther away is more likely to be conifers.

DEMs were generated from the point clouds using Golden Software's Surfer software. These were produced at $50-\mathrm{cm}$ resolution with an inverse distance weighted mean algorithm with a 4-m search radius, and at $10-\mathrm{cm}$ resolution with an inverse distance weighted mean algorithm with a $30-\mathrm{cm}$ search radius. The $50-\mathrm{cm}$ DEMs are more spatially complete because data gaps up to $4 \mathrm{~m}$ are interpolated. The 10-cm DEMs are less complete but are a more accurate representation of the input point cloud. The two resolutions of DEMs provide different results when used for elevation change mapping.

\section{Landscape Change Mapping}

To characterize streambank erosion, point- and channelbar deposition, and other topographic change, bare-earth DEMs generated from different years' data were subtracted from one another, generating DEMs of difference (DoDs) (for example, Wheaton and others, 2010). Comparisons with the 2006 airborne data (ALSM to TLS) were done at a grid resolution of $50 \mathrm{~cm}$, and comparisons between TLS datasets were done at both 10- and $50-\mathrm{cm}$ grid resolution. This provides different change-detection results: the $50-\mathrm{cm}$ grids appear the most spatially complete, but tend to have errors in locations in which data have been interpolated over longer distances, whereas the $10-\mathrm{cm}$ data can be considered higher accuracy but with data gaps in locations in which no data exists within $30 \mathrm{~cm}$.

Water and objects below water were not imaged by the laser scanners. Because of this, there are locations of no data in the change-detection results if an area that was ground one year then was water the next year owing to either changing water levels or lateral stream migration, so some real geomorphic change was missed when other data are compared to that collected in the somewhat higher water level of 2017. Stream discharge (as indicated by streamflow data are available at: https://irma. nps.gov/AQWebPortal/Data/Location/Summary/Location/ SIEN_YOSE_TUOLTIRO/Interval/Latest, accessed April 24, 2020) was about $0.8 \mathrm{~m}^{3} / \mathrm{s}$ during the 2006, 2016, and 2018 surveys. During the 2017 survey, discharge ranged from about 1 to $5 \mathrm{~m}^{3} / \mathrm{s}$, which led to several centimeters or more of difference in water surface elevation between that survey and the others. Procedures that would create a flat elevation surface across gaps created by presence of water were not implemented as they would unfavorably affect topographic comparisons. 


\section{Streambank Mapping}

Streambank locations in each dataset were manually digitized to properly quantify streambank erosion. Lines were digitized as close to the junction of the flat meadow surface and the sloped or vertical streambank as possible. These lines provided the clearest indication of stream bank dynamics in Tuolumne Meadows. Streambank positions were mapped as either "steep/active" or "indistinct/stable" (fig. 6). Any streambank can become active in a large flood or stabilized if sediment deposition leads to channel migration. For this study, the "steep/active" streambanks are mapped at high accuracy owing to their very distinct crest, and they tend to sit directly adjacent to the active channel, whereas those mapped as "indistinct/stable" are less accurate owing to their less defined morphology and subjective locations. "Indistinct/ stable" streambanks are often found at point bar locations on the inside bends of curves in the channel. The horizontal accuracy of mapped "steep/active" streambanks in 2016-2018 is estimated at about $30 \mathrm{~cm}$, and those mapped from the 2006 ALSM data have accuracy estimated at about $1 \mathrm{~m}$ owing to the coarser resolution base data. Most error comes from interpretation of ambiguities in streambank locations where they do not form a sharp slope break in the landscape.

To characterize erosion and deposition, the gridded elevation data were subtracted from one another to create DoDs at both 10and $50-\mathrm{cm}$ resolution. These DoDs only have values at locations which both input DEMs have pixel values, so a data gap in either DEM leads to a "no data" hole in the resulting DoD. These DoDs were interpreted with varying levels of detection (LoD) of elevation change that minimize errors from propagating into volumetric estimates of landscape change. These levels were 0,2 , and $10 \mathrm{~cm}$ for comparisons between TLS datasets, and 0,4 , and $10 \mathrm{~cm}$ for comparisons involving the 2006 ALSM data. These LoDs were implemented when gridded values of elevation change were integrated into volumetric estimates, such that only DoD pixel values exceeding these values were used. Error estimates and LoDs are discussed in more detail later in this report.

Though manual mapping of streambank locations from TLS and ALSM is the most accurate way to characterize streambank migration, other landscape changes such as deposition on channel and point bars is best characterized by the DoDs. However, dense vegetation and changes in vegetation annually can lead to errors in estimated elevation of true ground elevations. These errors in the bare-earth DEMs can then propagate into the change mapping, so caution is required when interpreting DoDs. This is especially apparent in low-relief areas relatively far from the scanner locations and in areas of thick grass that obscures the ground when viewed at a low angle. Occlusions caused by objects that block the laser instrument from surveying parts of the landscape can also lead to spurious landscape change in areas scanned in detail from one survey but not the next. This issue was mitigated by reoccupying the same scan positions each year. However, new survey positions were also added each year to expand the survey footprint and to increase density of survey data.

The two metrics computed to characterize landscape change are rate of streambank migration (that is horizontal change) from mapping, and volumetric change. Rate of streambank migration was calculated as the average distance a streambank

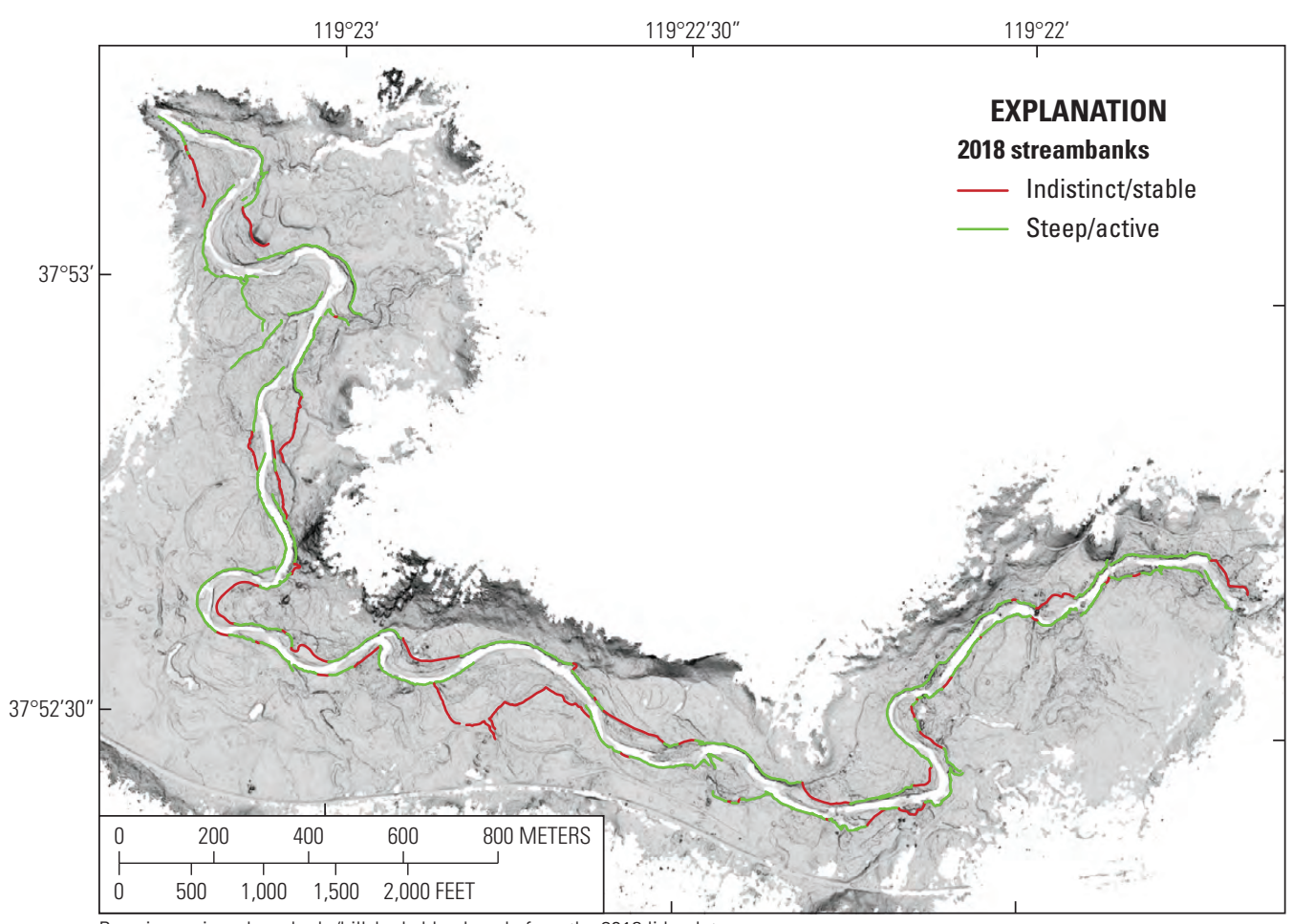

Base image is a slopeshade/hillshade blend made from the 2018 lidar data. Universal Transverse Mercator, zone 11 North; North American Datum of 1983
Figure 6. Map of indistinct/stable and steep/active areas along the Tuolumne River. Analyses of landscape change from DoDs and streambank mapping. 
migrated along the length of streambank that changed. Volumetric change was calculated in two ways. The first approach was to multiply average streambank retreat distances by the streambank height during the 2018 low-water conditions. This approach overestimates the volume of sediment removed because some material is transiently preserved as slump blocks and sloped material below the streambank even where the streambank has retreated. This material is likely removed in subsequent years when floods act upon the slumped blocks at the channel margin. Thus, the multiyear streambank retreat rate is proportional to the volumetric change rate, but with varying lag times owing to the time needed to remove transient slump-block material.

The second approach was to take a direct measurement of volumetric change from the DoD and apply it to streambanks as well as point and channel bars. For this, elevation changes were extracted at all locations where the $\mathrm{DoD}$ has data within specified areas. These areas include zones of erosion, zones of deposition, and the entire channel system. These data are less accurate when the relatively high-water 2017 survey was used because some pixels in 2017 were obscured by water covering sediment and were therefore not accounted for in the DoDs. In general, volumetric change calculated from 2006 or 2016 to 2017 will be an underestimate of true volumetric change. Elevation differences measured from 2006 to 2016 or 2018 and 2016 to 2018 should be more accurate representations of volumetric change because of similar water levels during those years. However, the true volumetric change at eroding streambanks is in between the two methods used here, and the horizontal displacement of streambank position is the most reliable indication of streambank migration.

Analyses were conducted and results presented for each erosion zone and include net erosion and deposition for a streambank and any channel or point bars adjacent to or directly across the channel from the streambank. This is not because sediment erosion and deposition are tightly coupled in a single location; generally eroded material from a streambank will be transported downstream rather than be deposited locally. However, because of interest in the stability of cross-sectional geometry and to provide data comparable to typical crosssection-based monitoring efforts, the dynamics of landscape change across the stream valley at locations of migrating streambanks may be of interest.

The TLS surveys were performed during the late-summer low-water conditions. The measured landscape change occurred mostly in the spring and (or) early summer of that year, primarily during snowmelt-caused peak river discharge, or as a result of rain events which happen occasionally throughout the years. As such, when, for example, "erosion from 2016-2017" is discussed, this erosion occurred mostly or totally in the spring and summer of 2017.

\section{Empirical Error Estimate Refinement Using Stable Landscape Areas}

The development of the DoD change maps provides an opportunity to further extract indicators of accuracy and LoD of elevation change. DoD values were extracted from areas judged most likely to be geomorphically stable and unvegetated over the survey intervals. These areas include the paved California Highway 120, gravel and dirt park service roads, gravel hiking trails, and bedrock outcrops. Before calculating statistics, we removed a very small amount of values of elevation change greater than $30 \mathrm{~cm}$ from these areas because these were either real geomorphic change that should not be used as stable areas for error analysis, isolated objects present in only one scan, or changes in vegetation. Table 2 presents these results. They indicate that comparisons between TLS data can be done using a LoD of about $0.1-1 \mathrm{~cm}$, and comparisons involving ALSM data can be done using a LoD of about $2-4 \mathrm{~cm}$. The average DoD value extracted from these areas is an indication of $\mathrm{LoD}$ in change mapping, and the standard deviation is best thought of as the amplitude of noise in the datasets caused by changing microtopography, variability in location of individual XYZ points within grid cells leading to averaging differences, and other scatter in the data, rather than a formal error metric. No specific evidence or knowledge exists of any road or trail grading occurring between surveys that would have affected these data. For results displayed in tables and discussed in this report, the LoD used for data derived from TLS to TLS comparisons was $2 \mathrm{~cm}$, and comparisons of TLS with ALSM data were performed with a LoD of $4 \mathrm{~cm}$.

\section{Results}

The three terrestrial laser scan surveys were used to generate the derived topographic data products available in DeLong and Pickering (2020). In the following sections, vegetation mapping, streambank mapping, and landscape change analyses are presented.

\section{Vegetation Mapping}

The three-dimensional point clouds contain information about not only the ground surface, but also all vegetation and objects above the ground. By gridding the elevation of points at the top of vegetation to generate "full featured" DEMs as well as those on the ground to generate bare-earth DEMs and subtracting the two models, vegetation canopy height can be characterized (fig. 4). These canopy maps indicate the contrast between the conifer forest (darker green) on the slopes adjacent to the meadow and the generally short vegetation (brown to light green) in the meadows. Along the stream channels, bare depositional bars are common, and some riparian vegetation is present.

To more specifically characterize vegetation types, the stature of meadow vegetation and riverside willows were considered. Tall willows in Tuolumne Meadows include Salix orestera, lemmonii, eastwoodiae, and planifolia (Sierra, Lemmon's, mountain, and diamondleaf willows, respectively), which have characteristic heights up to about $4 \mathrm{~m}$. Plants with heights up to $4 \mathrm{~m}$, and meadow vegetation between 0.25 and $1 \mathrm{~m}$ tall were extracted from the point clouds to characterize willow and meadow vegetation. 
Table 2. Indication of vertical accuracy of DEMs of difference (DoDs) using apparently stable areas including highway, gravel roads, gravel hiking trails, and natural bedrock outcrops.

[The average vertical differences indicate the level of elevation change that can be detected, and the standard deviation indicates the noise in the data. ALSM, airborne laser swath mapping; TLS, terrestrial laser scanning; m, meter]

\begin{tabular}{clcccc}
\hline $\begin{array}{c}\text { Surveys } \\
\text { compared }\end{array}$ & Surveys types & $\begin{array}{c}\text { Average vertical difference in } \\
\text { apparently stable areas }(\mathbf{m})\end{array}$ & $\begin{array}{c}\text { Standard Deviation } \\
(\mathbf{m})\end{array}$ & $\begin{array}{c}\text { Number of DoD } \\
\text { pixels used }\end{array}$ & $\begin{array}{c}\text { DoD pixel size } \\
(\mathbf{m})\end{array}$ \\
\hline $2006-2016$ & ALSM-TLS & 0.0180 & 0.109 & 31,157 & 0.5 \\
$2006-2017$ & ALSM-TLS & 0.0350 & 0.118 & 32,096 \\
$2006-2018$ & ALSM-TLS & 0.0370 & 0.114 & 33,594 & 0.5 \\
$2016-2017$ & TLS-TLS & 0.0090 & 0.052 & 0.5 \\
$2016-2018$ & TLS-TLS & 0.0079 & 0.053 & 261,085 \\
\hline $2017-2018$ & TLS-TLS & 0.0002 & 0.026 & 245,262 & 0.1 \\
\hline
\end{tabular}

The distribution of willows and shorter vegetation is shown in figure 5. This vegetation mapping is not a substitute for field mapping and was not verified for accuracy in detail. Rather, it is intended to provide a general characterization of vegetation in the meadow and adjacent to the Tuolumne River channel. Patterns of vegetation did not change dramatically during 2016-2018. Data to explore vegetation in more detail are available in DeLong and Pickering (2020).

\section{Streambank Mapping}

Mapped "steep/active" streambanks were used to identify areas of recent channel migration and streambank erosion. Changes in mapped position of "indistinct/stable" streambanks do not necessarily indicate geomorphic change as these tend to be farther from the active channel, often protected by low terraces and gravel and (or) sand bars which are distinguished by inherently less abrupt changes in slope angles, and therefore these are not always mapped in a repeatable fashion. Figure 6 displays all streambank positions mapped from the 2018 lidar data. Because change in position of the streambanks is on the order of centimeters to meters over the duration of the study, the details of landscape change are best viewed at larger mapping scales. The mapped streambanks are available in DeLong and Pickering (2020).

\section{Zones of Active Streambank Migration and Landscape Change}

Examining maps of elevation change and streambank positions indicate that there are 15 zones of streambanks that tended to erode during the survey intervals (fig. 7). These are all on cut banks on the outside bends of the Tuolumne River. There are other small zones of streambank erosion, but they are not as active and extensive as the 15 zones identified in figure 7 . Among the 15 zones of active erosion - herein referred to as erosion zones - there is considerable variability in the degree of streambank migration ranging from decimeters to several meters. These locations at the outside bends of the channel have depositional point bars opposite of them, and some have depositional bars nearby in the channel - herein referred to as channel bars. To characterize the interplay between local erosion and deposition at each erosion zone (with the acknowledgment that both are influenced by larger system dynamics rather than just local processes), the depositional areas at each erosion zone were mapped and analyzed (fig. 8). These analyses were limited to the unvegetated sediment bars in and adjacent to channels because no evidence of substantial deposition on the higher vegetated bars or meadow surface was observed. Some vegetation debris that was carried by floodwater was deposited in the lower part of the lowest riparian vegetation above the unvegetated point bars. This indicates maximum flood elevation reached to just above the unvegetated bars. The sediment that was carried as bedload and suspended load was deposited almost entirely on the unvegetated lower bars.

The results from streambank mapping, vegetation mapping, and development of DoDs are shown in figures 9-52. These figures include bare-earth slopeshades, DoDs, vegetation canopy heights, locations of short meadow and riparian willow vegetation, and field photographs. No systematic effort was made to document conditions with photography. The included photos were taken of the landscape during fieldwork, though not in a methodical manner. A larger collection of photographs is included in DeLong and Pickering (2020), as are all data used to create figures 9-52. The best way to visualize the details of streambank migration is to use the keyhole markup language (.kmz) files or the shapefiles included in DeLong and Pickering (2020) along with the raster and point cloud data. Full 3D change detection was not performed in this study, but the point clouds could be used with methods such as point-to-point, point-to-mesh, or the M3C2 algorithm (Lague and others, 2013) for more detailed analysis of landscape change at local sites.

Tables 3-17 report the extracted values of volumetric change and streambank retreat for the fifteen erosion zones and their adjacent depositional bars. Values were reported from each survey interval comparing TLS to TLS data with a LoD of $2 \mathrm{~cm}$. Values were reported from each survey interval comparing TLS to ALSM data with a LoD of $4 \mathrm{~cm}$. This was chosen based on the statistics presented in table 2 that indicate TLS-TLS repeatability of about $1 \mathrm{~cm}$ and changes involving ALSM data having a LoD of less than about $4 \mathrm{~cm}$. All data extracted with LoDs between 0 and $10 \mathrm{~cm}$ are available in DeLong and Pickering (2020). Using an LoD of $0 \mathrm{~cm}$ (using all elevation change data) produces nearly indistinguishable results from those using a $2-\mathrm{cm}$ or $4-\mathrm{cm}$ LoD. Using an LoD of 


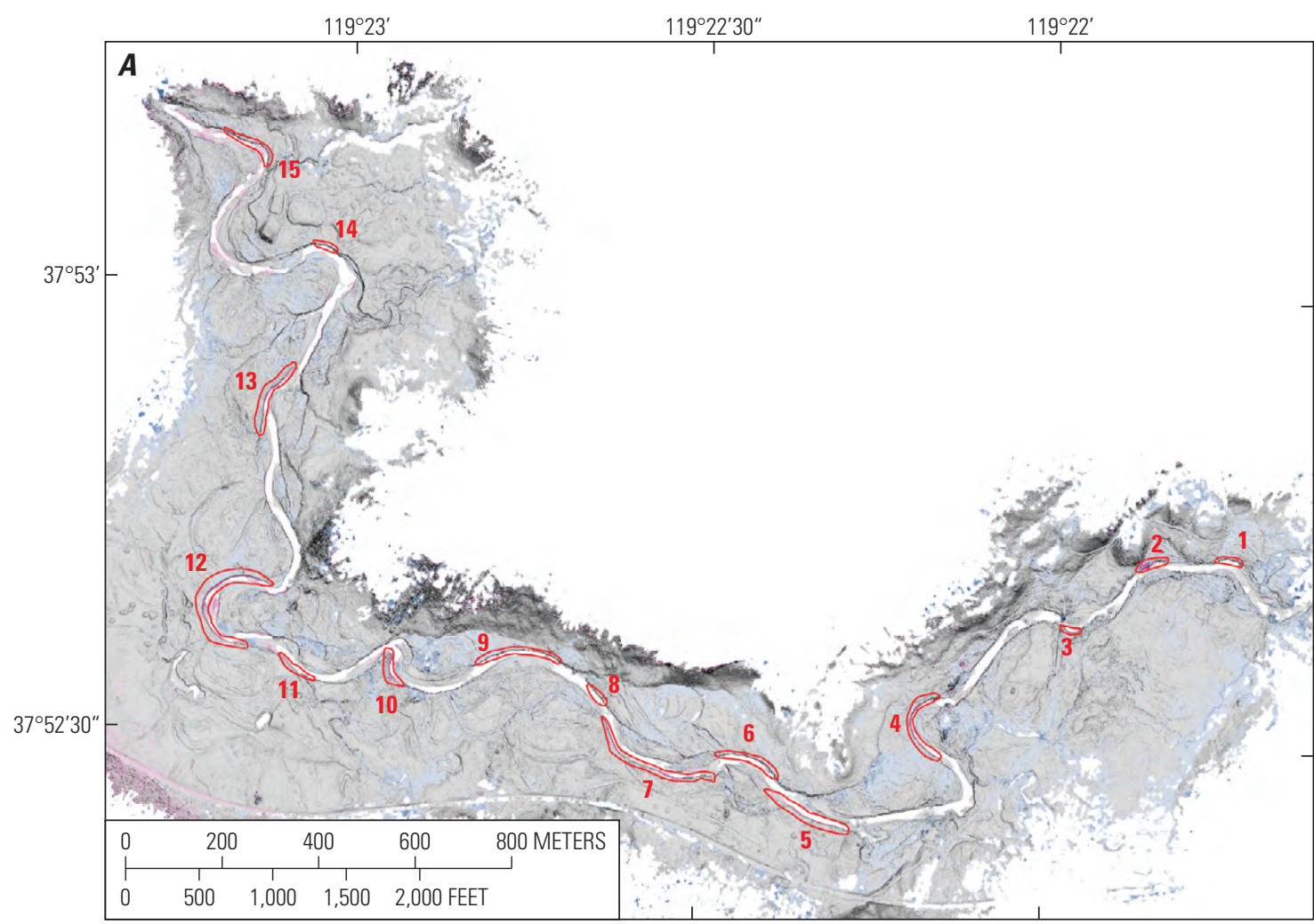

\section{EXPLANATION}

Elevation change, in meters

\begin{tabular}{|l|}
\hline 4 to 2 \\
2 to 1 \\
1 to 0.5 \\
0.5 to 0.2 \\
0.2 to -0.2 \\
-0.2 to -0.5 \\
-0.5 to -1 \\
-1 to -2 \\
-2 to -6 \\
\hline
\end{tabular}

\section{Willows}

6 Zones of consistent streambank migration -"Erosion zones"

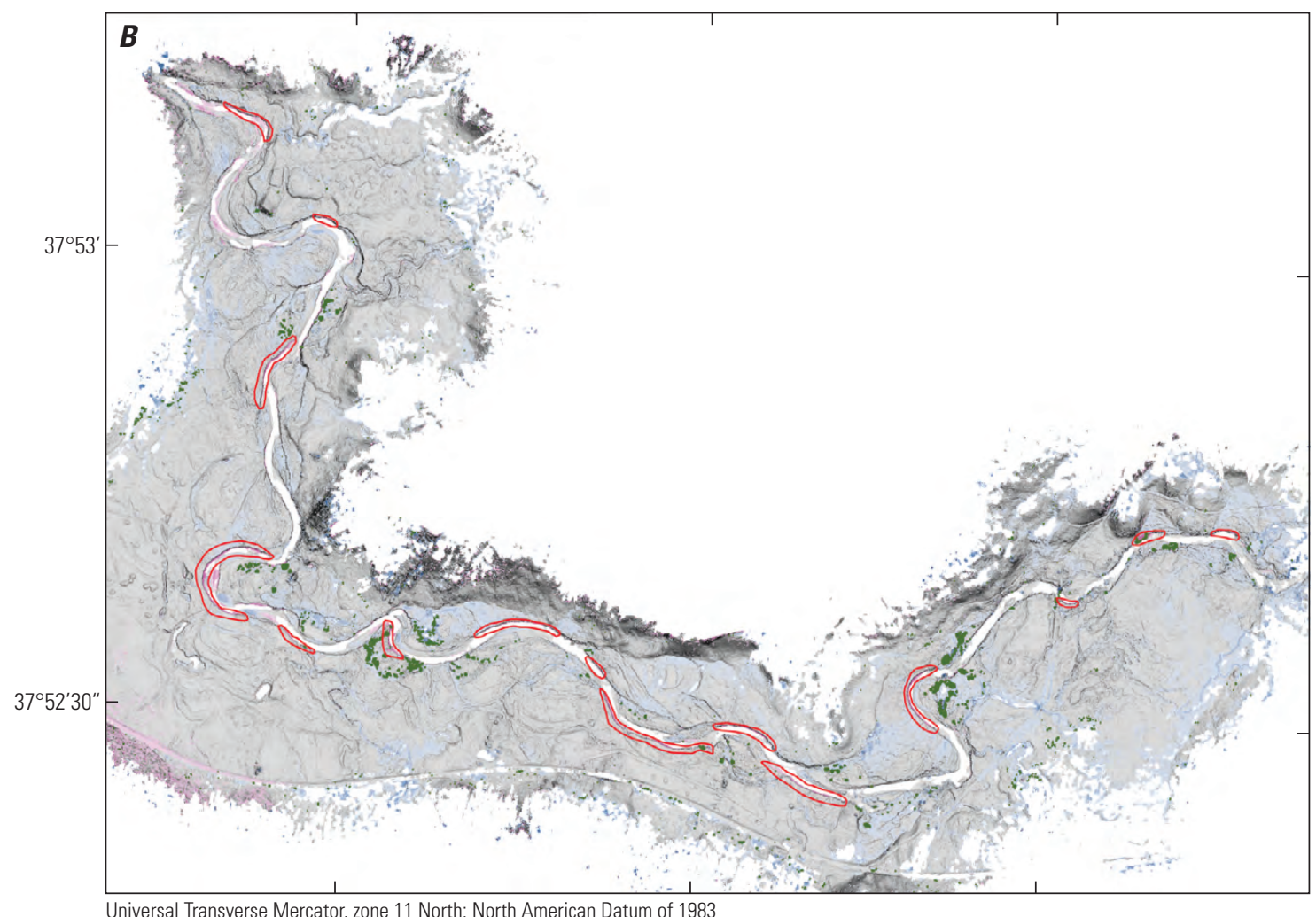

Universal Transverse Mercator, zone 11 North; North American Datum of 1983

Figure 7. Maps depicting elevation changes from 2006 to 2018 in Tuolumne Meadows. Elevation change is depicted in partly transparent colors and is generally too localized to be clearly visible at this scale. The fifteen locations ("erosion zones") where streambanks appear to migrate consistently are outlined in red and numbered for reference in $A$, and displayed in more detail in subsequent figures. $B$, also depicts locations of vegetation most likely to be streambank willows as extracted from the 2018 TLS point cloud. 


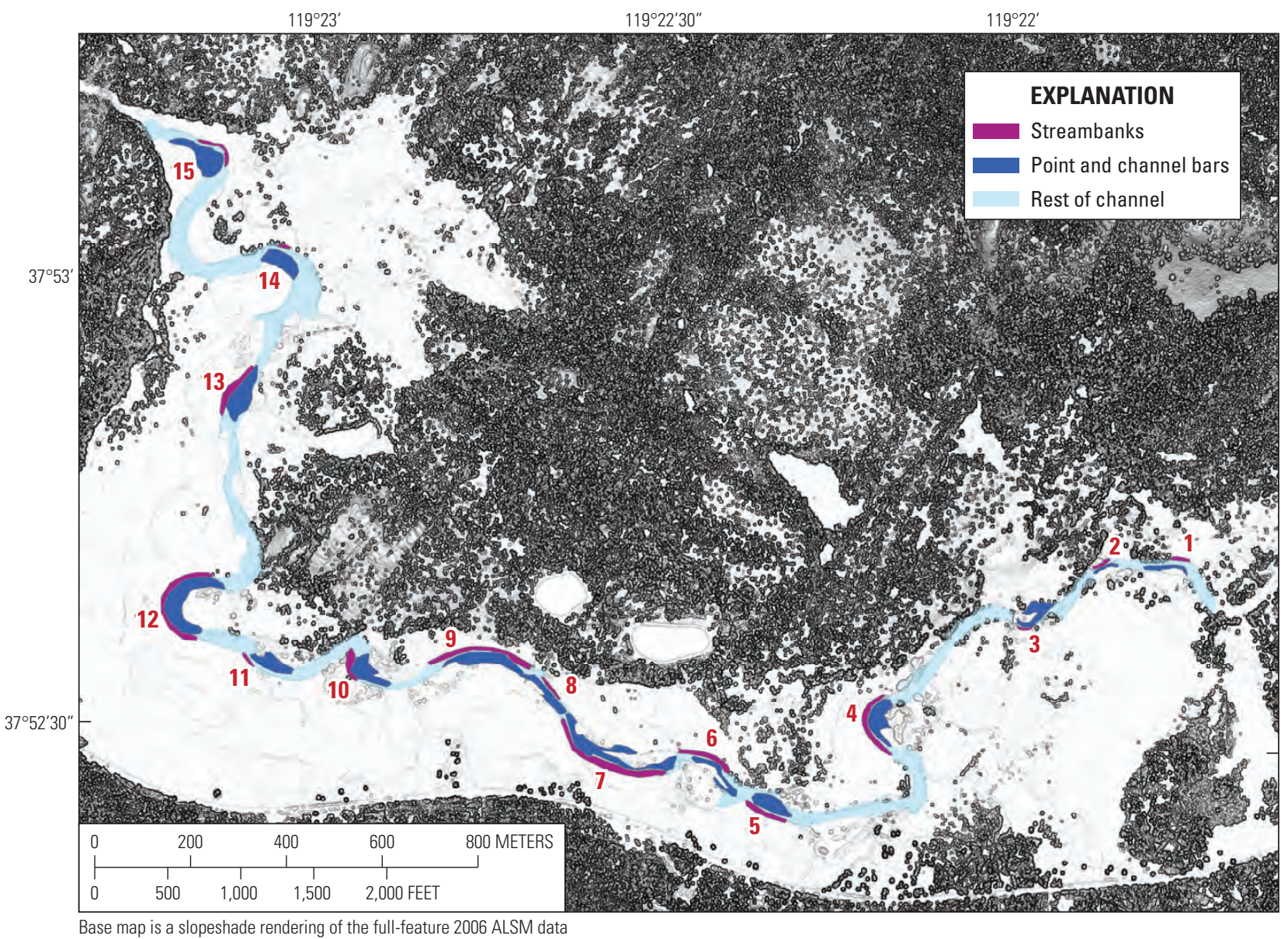

Figure 8. Map of polygons used to extract erosion and deposition volumes along the Tuolumne River, numbered by erosion zone. Magenta zones are streambanks, bright blue zones are point and channel bars, and light blue zones are the polygons used to extract volumetric change across the entire channel reach.

$10 \mathrm{~cm}$ leads to lower estimates of point and channel bar deposition but similar estimates for streambank erosion. Point bar deposition occurs as layers of sediment are deposited over large areas of the bar. Given the high sensitivity of methods employed in this study, very slight elevation changes can be detected on unvegetated bars and this landscape change is not fully quantified if a LoD of $10 \mathrm{~cm}$ is used. Sediment deposition on point and channel bars less than $20 \mathrm{~cm}$ thick is not visible on the change detection maps (figs. 9-67). These areas are portrayed as transparent in locations at which elevation change is less than $20 \mathrm{~cm}$ because maps that display changes as small as 2 or $4 \mathrm{~cm}$ are visually dominated by very small elevation changes in vegetated areas beyond the erosion and deposition zones analyzed in detail.

Values for erosion at the 15 streambank erosion zones are converted to rates and summarized in table 18 . The most reliable DoD-derived streambank data are from 2006 to 2016 and 2016 to 2018 because they do not include the 2017 high water conditions.

The rates of deposition on point and channel bars are reported in table 19. The most reliable DoD-derived data are those from 2006 to 2016 and 2016 to 2018 . These data are less sensitive to the 2017 high-water conditions than are the erosion data because most deposition occurs above the water levels present during any survey.
To present the sediment dynamics across the entire surveyed reach of the Tuolumne River, metrics were extracted from an area encompassing the entire channel and streambank system (fig. 8). These are reported in table 20.

Because the local planform geometry of the stream channel may control the forces acting on streambanks, we also measured channel sinuosity at each erosion zone. This was done by measuring the shortest straight-line distance and the distance along the curved channel centerline to approximate the thalweg, from the next prominent bend upstream and downstream of each erosion zone. These are reported in table 21.

\section{Details of Landscape Change at Erosion Zones}

Examination of change maps and streambank mapping indicate that there are 15 erosion zones that eroded most during the survey intervals (fig. 7). These are all on outside bends of the Tuolumne River. There are other small zones of streambank erosion, but they are not as active and extensive as the 15 erosion zones identified in figure 7. Below are descriptions of results at each identified erosion zone. To fully visualize the results, point clouds, rasters, and mapped streambanks are available in DeLong and Pickering (2020). 


\section{Erosion Zone 1}

Erosion zone 1 is downstream of a large channel bar at a westward bend in the Tuolumne River (fig. 9). The erosion zone is slightly protected by short vegetation at the channel edge, and the low terrace towards which the streambank is migrating is covered in short grassy vegetation, most of which is less than $25 \mathrm{~cm}$ tall (figs. 10 and 11). Erosion observed at this zone is less than at most other erosion zones. The streambank migrated less than an average of $1 \mathrm{~m}$ along the length that eroded between 2006 and 2018. This was along a less than $15 \mathrm{~m}$ length of streambank (table 3). From 2006 to 2016, bank erosion of between about 24 and $32 \mathrm{~m}^{3}$ (these values are the amounts estimated by DoD analysis and the amount estimated by streambank mapping analysis, respectively. The streambank-mapping-derived values generally are overestimates because some sediment is stored as slump blocks adjacent to the retreating streambanks. These values exceeded point bar deposition of about $15 \mathrm{~m}^{3}$ on the small point bar across the channel. Between 2016 and 2018, the streambank migrated a maximum of just a few decimeters resulting in erosion of about $5.2-6.7 \mathrm{~m}^{3}$ of sediment (these values are the sum of volumes from positions of 2016-2018 streambank mapping, and the values extracted from the DoD are in table 3 , respectively). This streambank erosion was balanced by deposition on the small point bar opposite of the eroding bank; about $6.8 \mathrm{~m}^{3}$ of sediment was deposited during 2016-2018. The large channel bar just upstream was not considered in this erosion zone analysis but apparent net deposition likely contributed to the overall deposition extracted from the full channel area analysis.

Table 3. Estimates of erosion and deposition at erosion zone 1 along Tuolumne River.

[---, no data; DEM, digital elevation model; DoD, DEMs of difference; m, meter, $\mathrm{m}^{2}$, square meter; $\mathrm{m}^{3}$, cubic meter]

\begin{tabular}{|c|c|c|c|c|c|c|c|c|}
\hline \multirow[b]{2}{*}{$\begin{array}{l}\text { Erosion } \\
\text { zone }\end{array}$} & \multirow[b]{2}{*}{$\begin{array}{l}\text { Surveyed } \\
\text { interval }\end{array}$} & \multirow[b]{2}{*}{$\begin{array}{c}\text { Streambank } \\
\text { or bar }\end{array}$} & \multicolumn{2}{|c|}{ From DEM change mapping } & \multicolumn{4}{|c|}{ From streambank mapping } \\
\hline & & & $\begin{array}{l}\text { Area of data } \\
\text { in zone }\left(\mathrm{m}^{2}\right)\end{array}$ & $\begin{array}{l}\text { Volume change from DoD } \\
\qquad\left(\mathrm{m}^{3}\right)\end{array}$ & $\begin{array}{c}\text { Active } \\
\text { streambank } \\
\text { length }(\mathrm{m})\end{array}$ & $\begin{array}{l}\text { Bank } \\
\text { height } \\
\text { (m) }\end{array}$ & $\begin{array}{l}\text { Average } \\
\text { bank } \\
\text { retreat }(\mathrm{m})\end{array}$ & $\begin{array}{l}\text { Volume change } \\
\text { from streambank } \\
\text { mapping }\left(\mathrm{m}^{3}\right)\end{array}$ \\
\hline 1 & 2006-2016 & Bar & 497 & ${ }^{\mathrm{a}} 15.2$ & --- & --- & --- & --- \\
\hline 1 & 2006-2016 & Bank & 208 & b-23.9 & 30 & 1.35 & 0.80 & -32.4 \\
\hline 1 & 2006-2017 & Bar & 151 & a 29.3 & --- & --- & --- & --- \\
\hline 1 & $2006-2018$ & Bar & 504 & a25.7 & --- & --- & --- & --- \\
\hline 1 & $2006-2018$ & Bank & 189 & $\mathrm{a}-25.5$ & --- & --- & --- & --- \\
\hline 1 & $2016-2017$ & Bar & 45 & b4.2 & --- & --- & --- & --- \\
\hline 1 & 2016-2017 & Bank & 105 & $\mathrm{~b}-3.0$ & 5 & 1.35 & 0.10 & -0.7 \\
\hline 1 & 2016-2018 & Bank & 112 & ${ }^{b}-6.7$ & --- & --- & --- & --- \\
\hline
\end{tabular}

${ }^{\mathrm{a} C a l c u l a t e d ~ f r o m ~ 50-c m-r e s o l u t i o n ~ d i g i t a l ~ e l e v a t i o n ~ m o d e l s ~ a t ~ 4-c m ~ l e v e l ~ o f ~ d e t e c t i o n . ~}$

${ }^{\mathrm{b}}$ Calculated from 10-cm-resolution digital elevation models at 2-cm level of detection. 


\section{A. 2006 ALSM slopeshade}

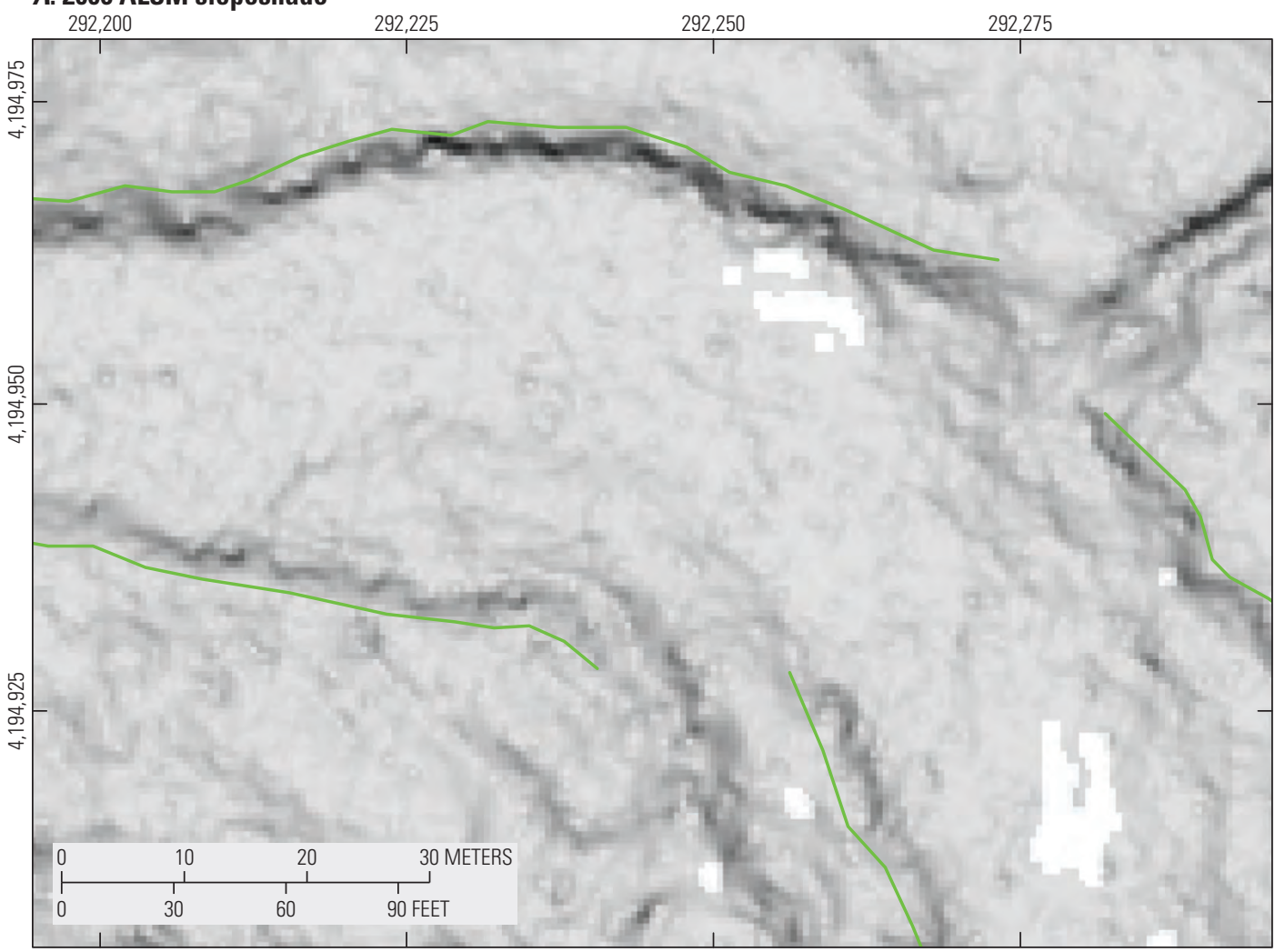

\section{B. Landscape change from 2006-16 on 2016 TLS slopeshade}

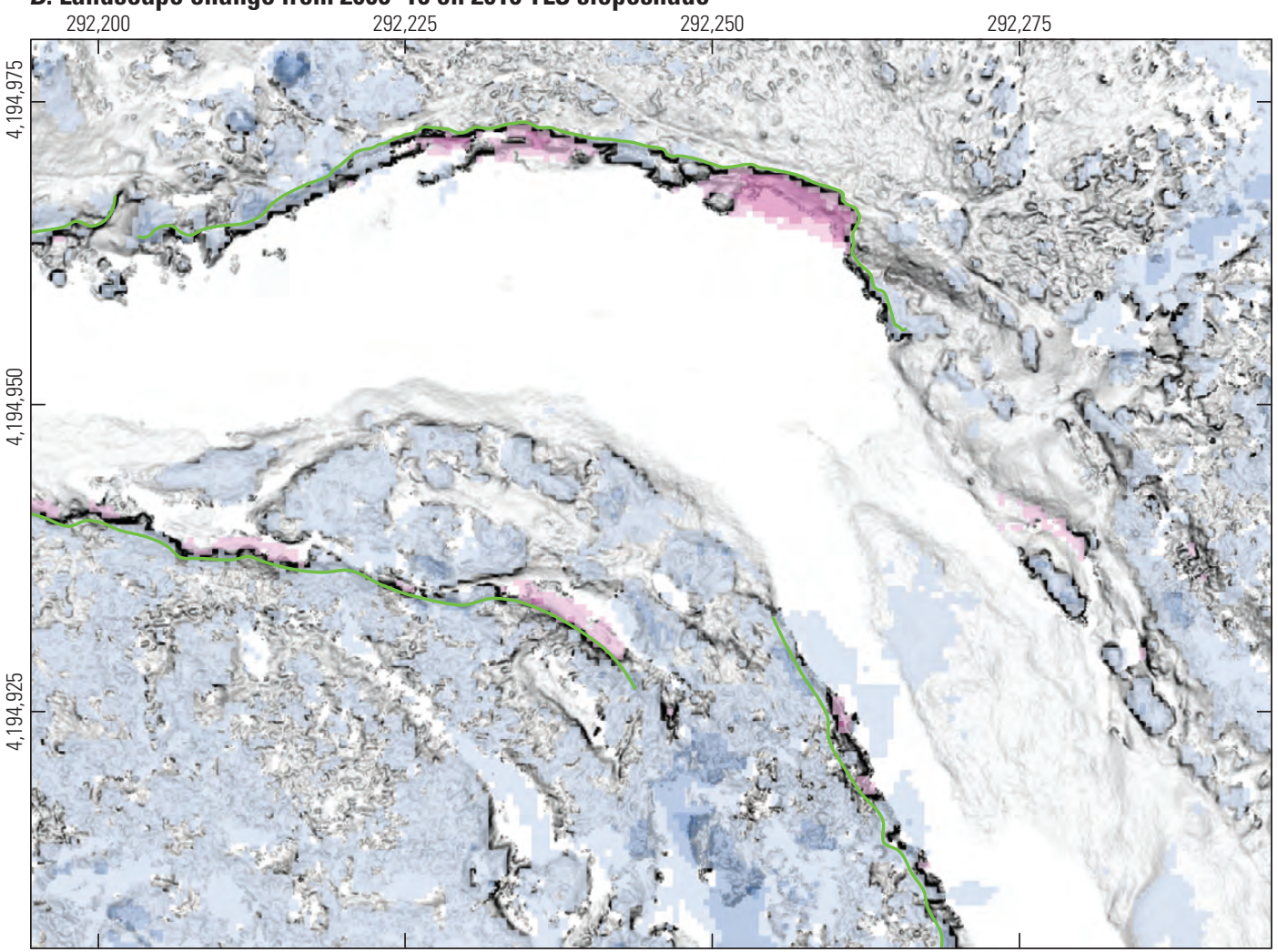

EXPLANATION

2006 streambanks

_ Indistinct/stable

— Steep/active

\section{EXPLANATION}

Elevation change, in meters

4 to 2
2 to 1
1 to 0.5
0.5 to 0.2
0.2 to -0.2
-0.2 to -0.5
-0.5 to -1
-1 to -2
-2 to -6

2016 streambanks

Indistinct/stable Steep/active

Figure 9. Lidar-derived maps showing location and classification of stream banks at erosion zone 1. A, 2006 airborne laser swath mapping (ALSM) bare-earth slopeshade with mapped streambanks. B, 2016 terrestrial laser scanning (TLS) bare-earth slopeshade. C, 2017 TLS bare-earth slopeshade. D, 2018 TLS bare-earth slopeshade. Colors indicate geomorphic change, and lines are mapped streambanks. 
C. Landscape change from $2016-17$ on 2017 TLS slopeshade

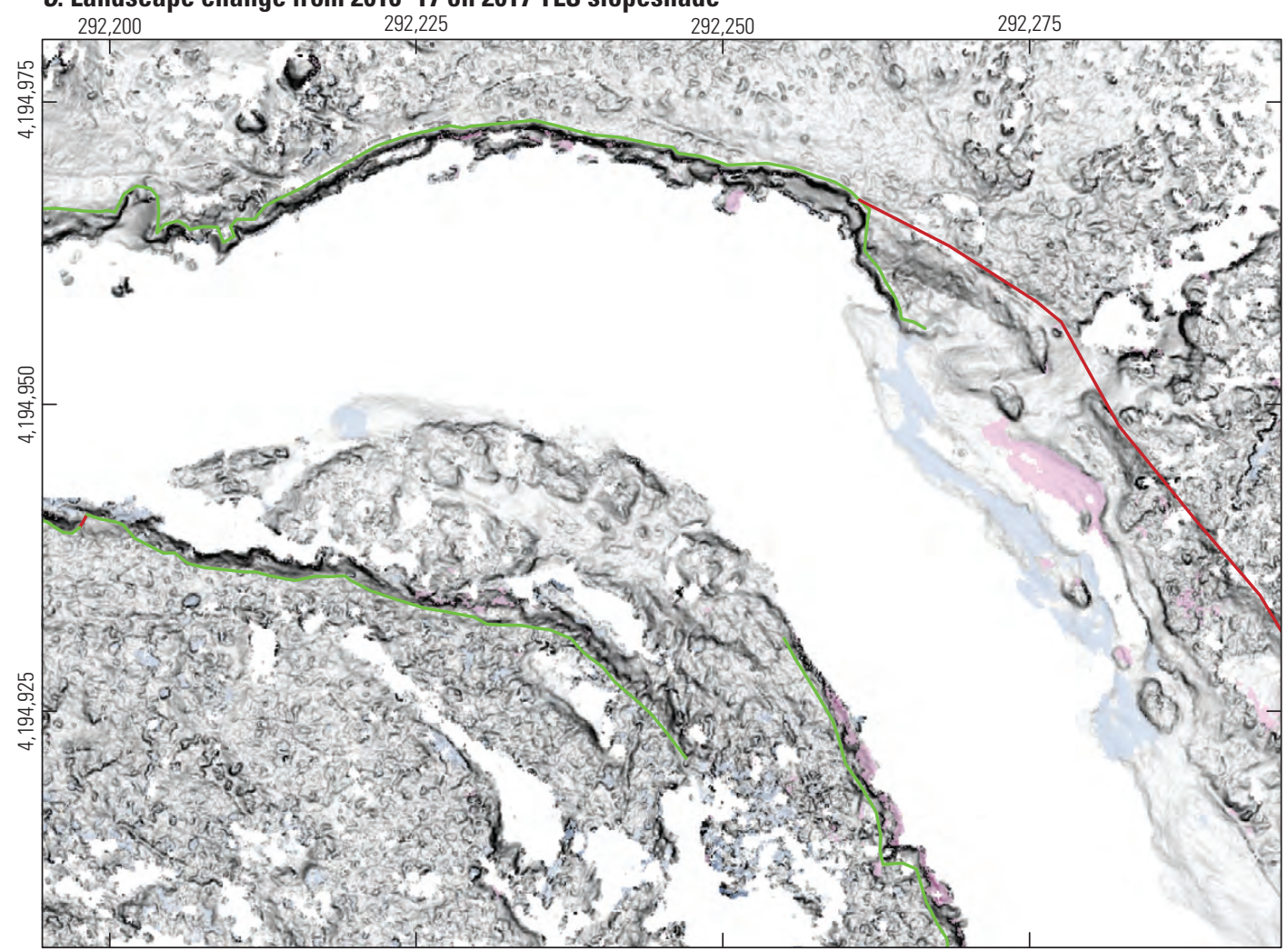

D. Landscape change from 2017-18 on 2018 TLS slopeshade

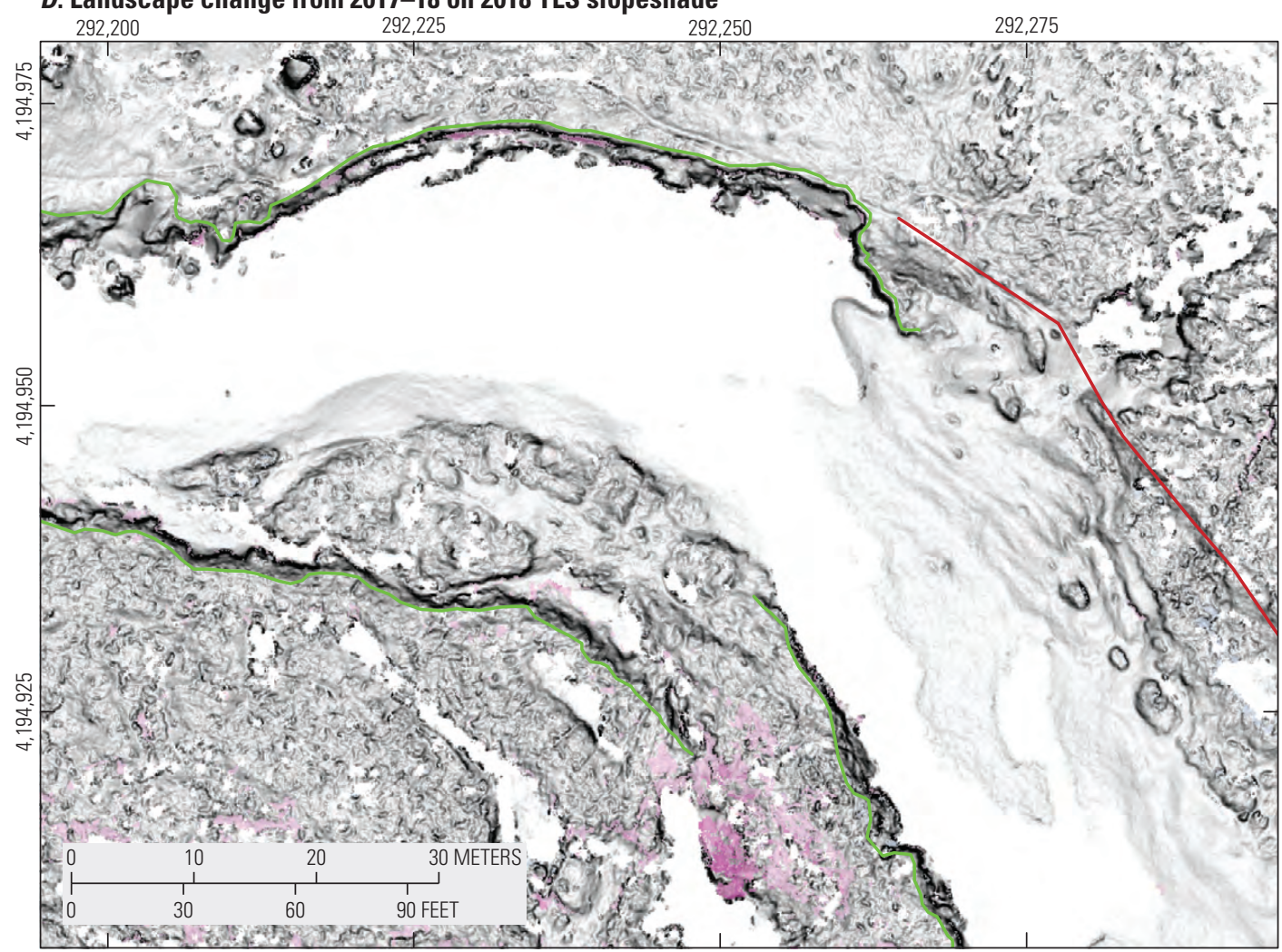

Universal Transverse Mercator, zone 11 North; North American Datum of 1983

\section{EXPLANATION}

Elevation change, in meters

\begin{tabular}{|l|}
4 to 2 \\
2 to 1 \\
1 to 0.5 \\
0.5 to 0.2 \\
0.2 to -0.2 \\
-0.2 to -0.5 \\
-0.5 to -1 \\
-1 to -2 \\
-2 to -6
\end{tabular}

2017 streambanks

_ Indistinct/stable Steep/active

\section{EXPLANATION}

Elevation change, in meters

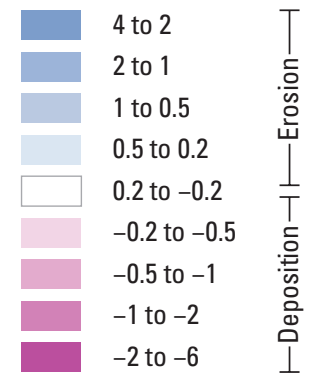

2018 streambanks

__ Indistinct/stable Steep/active

Figure 9.-Continued 


\section{A. Vegetation canopy height from 2018 TLS data}

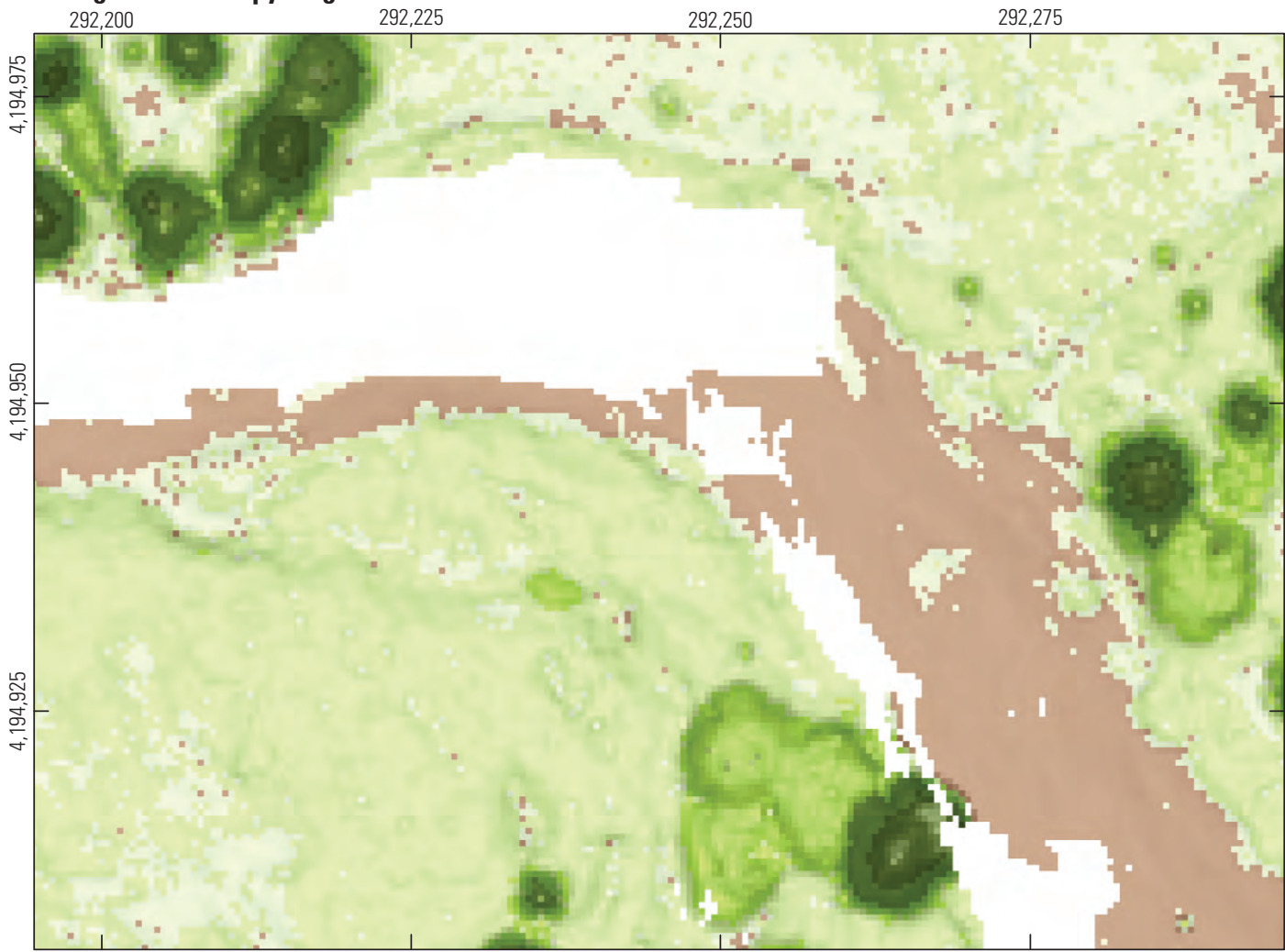

B. Presence of streambank willows and other meadow vegetation from 2018 TLS data

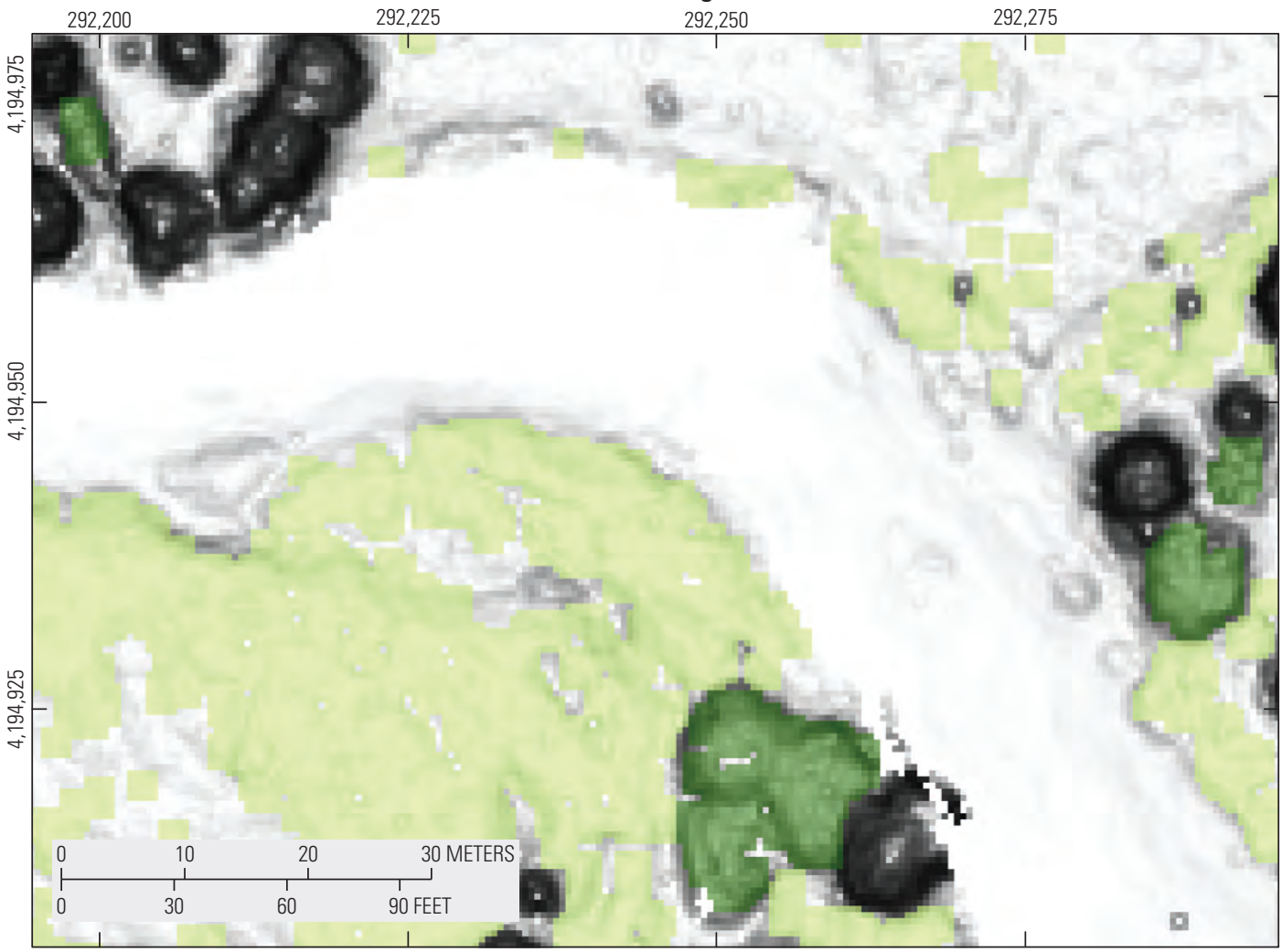

Universal Transverse Mercator, zone 11 North; North American Datum of 1983

\section{EXPLANATION}

Canopy height, in meters

$<0.1$

0.1 to 0.25

0.25 to 1

1 to 2

2 to 4

4 to 10

10 to 20

20 to 30

30 to 50
EXPLANATION

Canopy height, in meters

0.25 to 1 -Short vegetation

1 to 4 -Mostly willows

Figure 10. Lidar-derived maps of vegetation at erosion zone 1. Data are from 2018 terrestrial laser scanning (TLS). $A$, shows a semitransparent canopy-height model over full-feature slopeshade. $B$, shows a map of vegetation most likely to be streambank willows and meadow vegetation. 

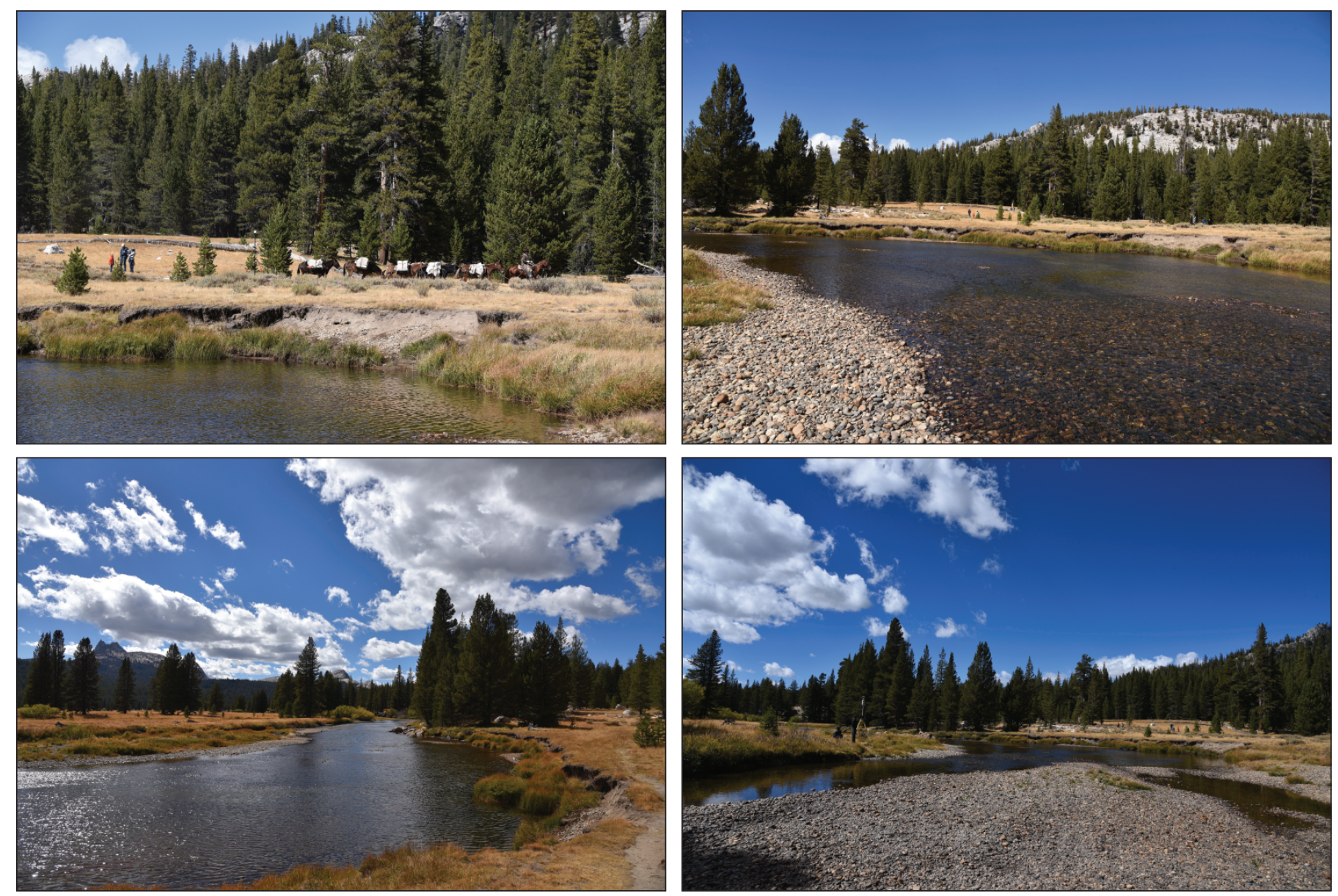

Figure 11. U.S. Geological Survey photographs of erosion zone 1, taken in 2016.

\section{Erosion Zone 2}

Erosion zone 2 is along a relatively straight section of the Tuolumne River channel (fig. 12). The 2006 ALSM data contain an area of dense vegetation (large area of magenta in figure 12), that is apparently a patch of vegetation so dense and even in height that it was classified as ground in the 2016 ALSM data (fig. 13). This apparent error influences change analyses that include the 2006 data, by increasing erosion values considerably. Streambanks in this area retreated an average of $1 \mathrm{~m}$ in 2006-2016, $1.2 \mathrm{~m}$ in 2017, and $0.8 \mathrm{~m}$ in 2018 (table 4). There was only modest deposition on the point bar opposite the streambank of $3.9 \mathrm{~m}^{3}$ from 2006 to 2016 and $8.8 \mathrm{~m}^{3}$ from 2016 to 2018 , and the overall trend in the area was of erosion outpacing deposition. From 2016 to 2018 , streambank erosion was about 29-52 $\mathrm{m}^{3}$ (calculated from $\mathrm{DoD}$ and streambank mapping, respectively). Aside from the effect of the misclassified vegetation in the 2006 ALSM data, landscape change in this zone was modest. 
A. 2006 ALSM slopeshade

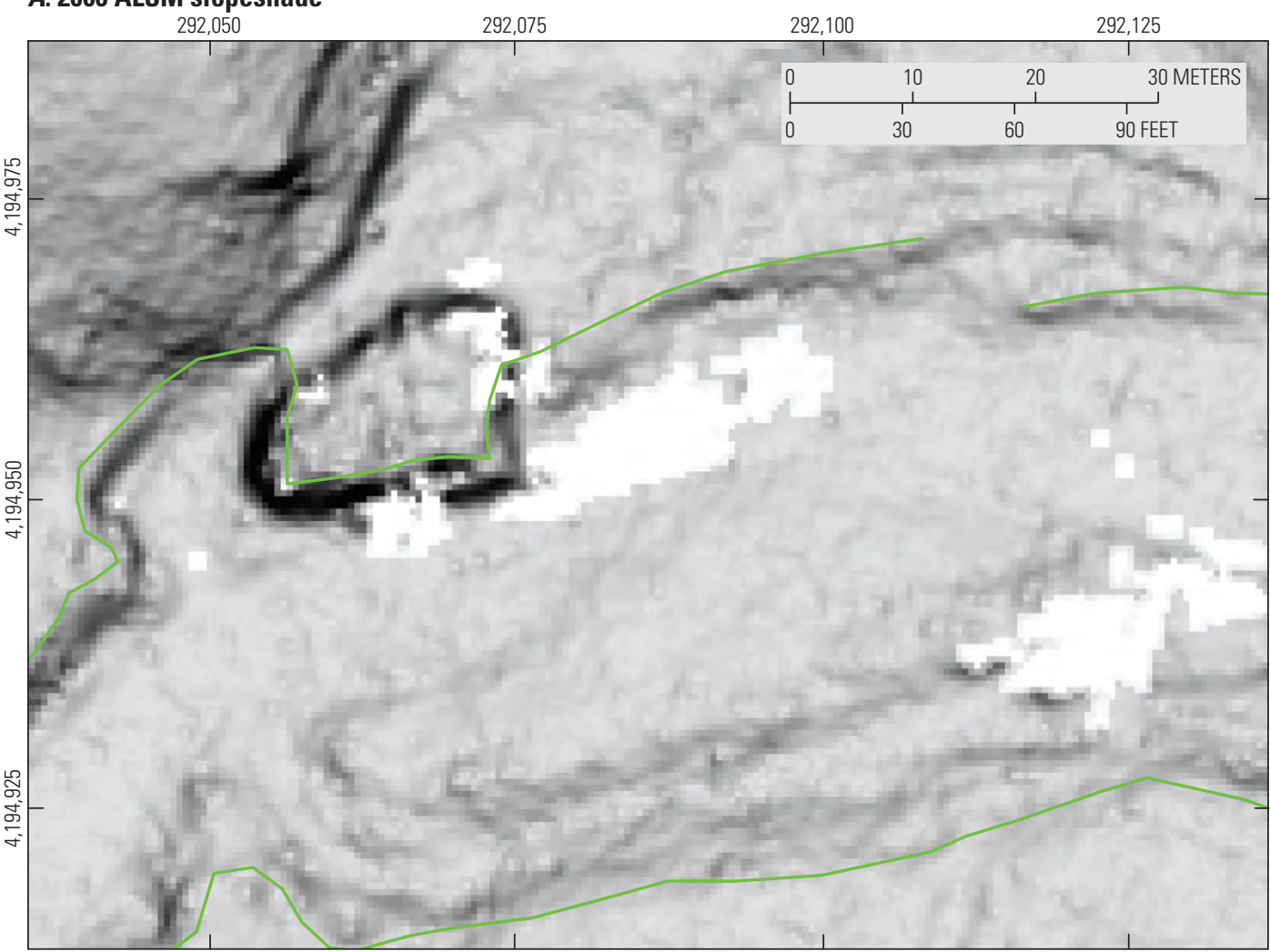

B. Landscape change from 2006-16 on 2016 TLS slopeshade

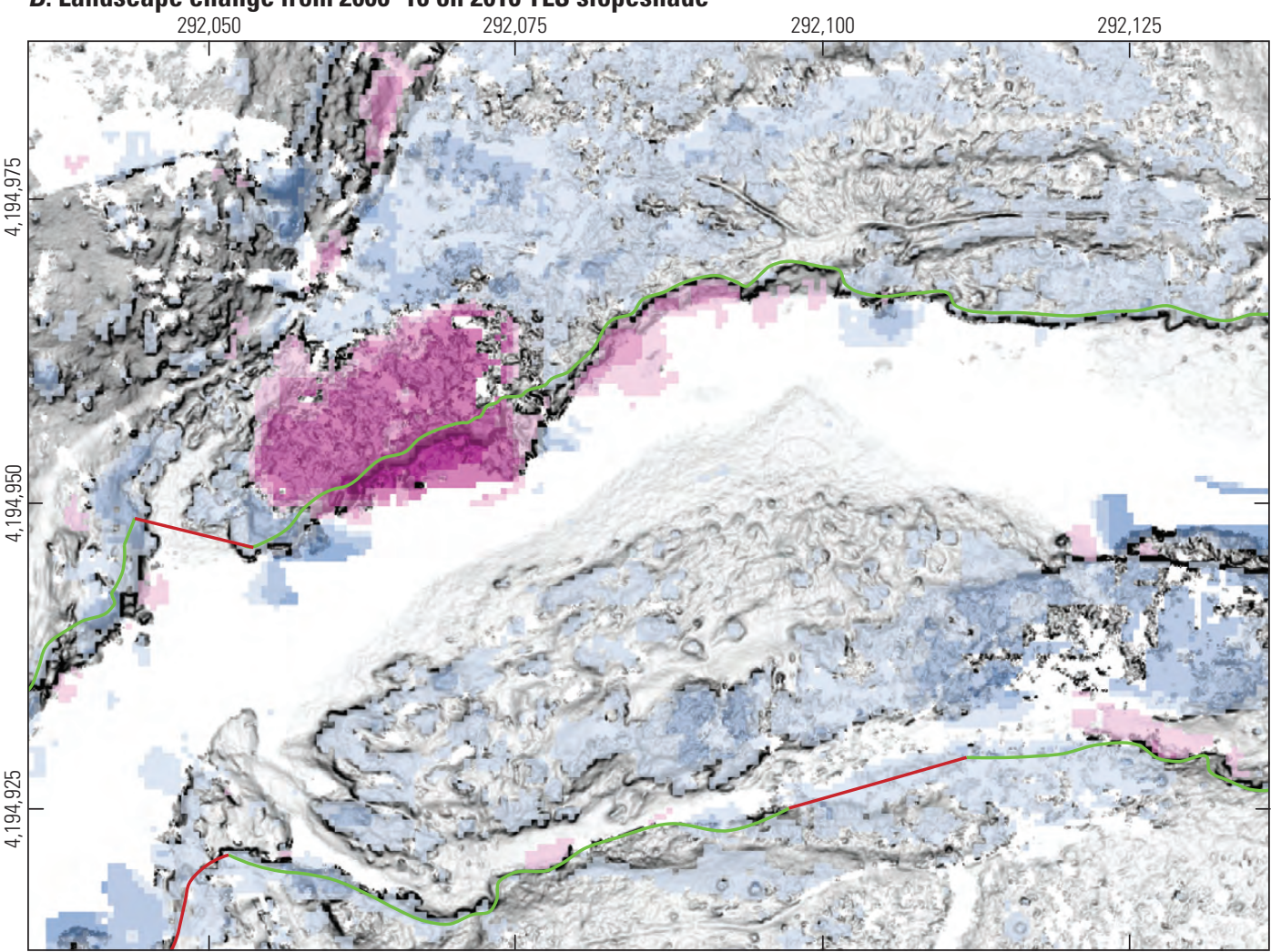

Universal Transverse Mercator, zone 11 North; North American Datum of 1983

\section{EXPLANATION}

2006 streambanks

_ Indistinct/stable

Steep/active
EXPLANATION

Elevation change, in meters

4 to 2

2 to 1

1 to 0.5

0.5 to 0.2

0.2 to -0.2

-0.2 to -0.5

-0.5 to -1

-1 to -2

-2 to -6

2016 streambanks

- Indistinct/stable Steep/active

Figure 12. Lidar-derived maps showing location and classification of stream banks at erosion zone 2. A, 2006 airborne laser swath mapping (ALSM) bare-earth slopeshade with mapped streambanks. B, 2016 terrestrial laser scanning (TLS) bare-earth slopeshade. C, 2017 TLS bare-earth slopeshade. D, 2018 TLS bare-earth slopeshade. Colors indicate geomorphic change, and lines are mapped streambanks. The large area of negative change in panel $B$ may be a result of insufficient vegetation penetration by the 2006 airborne scan leading to vegetation being incorrectly classified as ground. This area was thick brush in 2016-2018. 
C. Landscape change from 2016-17 on 2017 TLS slopeshade

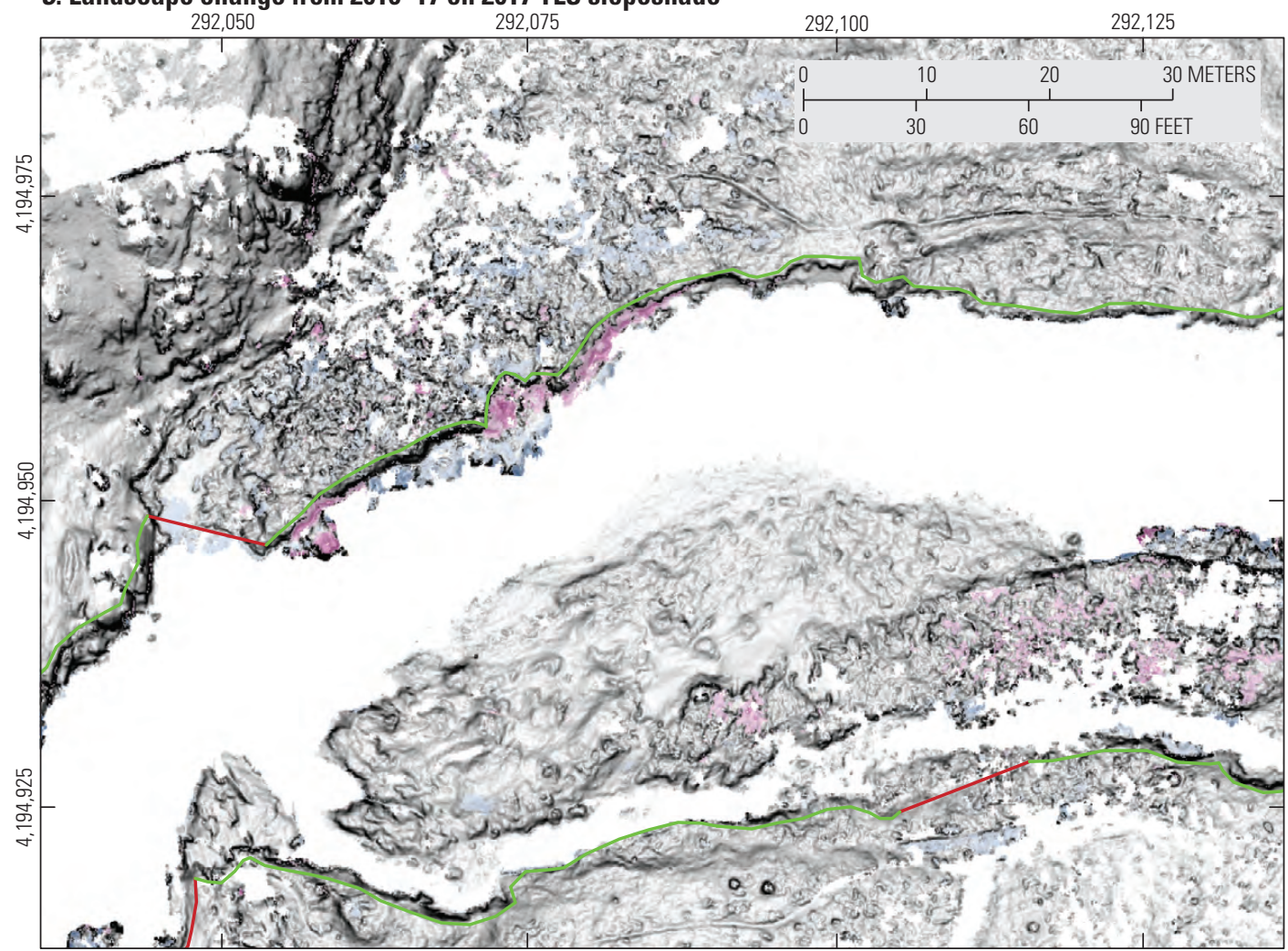

\section{EXPLANATION}

Elevation change, in meters

\begin{tabular}{|l|}
4 to 2 \\
2 to 1 \\
1 to 0.5 \\
0.5 to 0.2 \\
0.2 to -0.2 \\
-0.2 to -0.5 \\
-0.5 to -1 \\
-1 to -2 \\
-2 to -6 \\
\hline
\end{tabular}

2017 streambanks

_ Indistinct/stable Steep/active

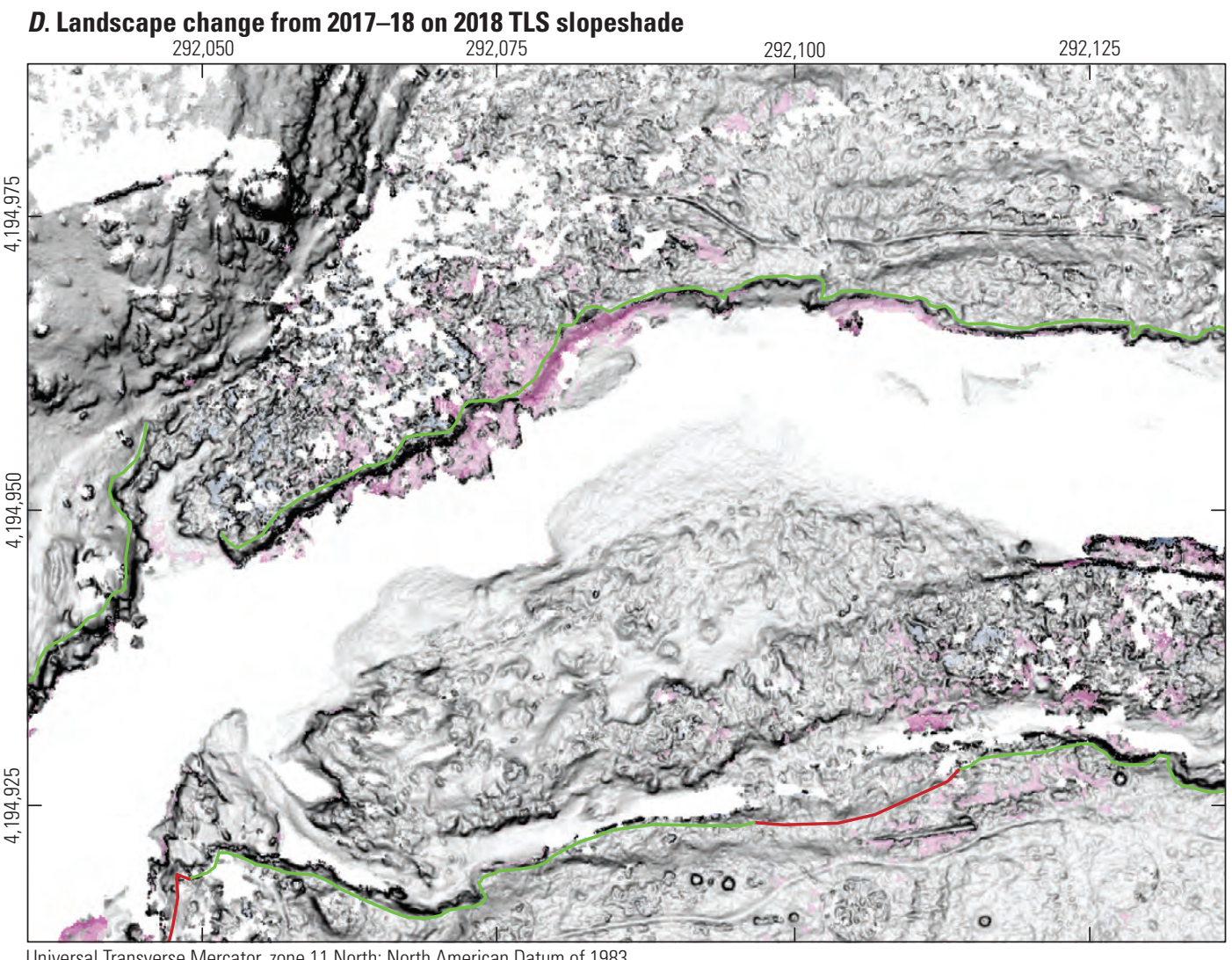

\section{EXPLANATION}

Elevation change, in meters

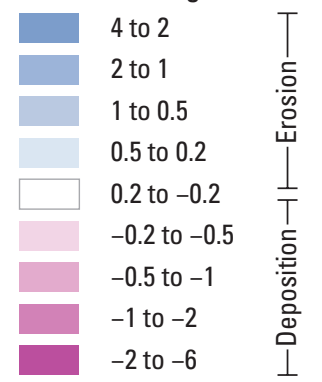

2018 streambanks

__ Indistinct/stable - Steep/active

Figure 12.-Continued 
A. Vegetation canopy height from 2018 TLS data

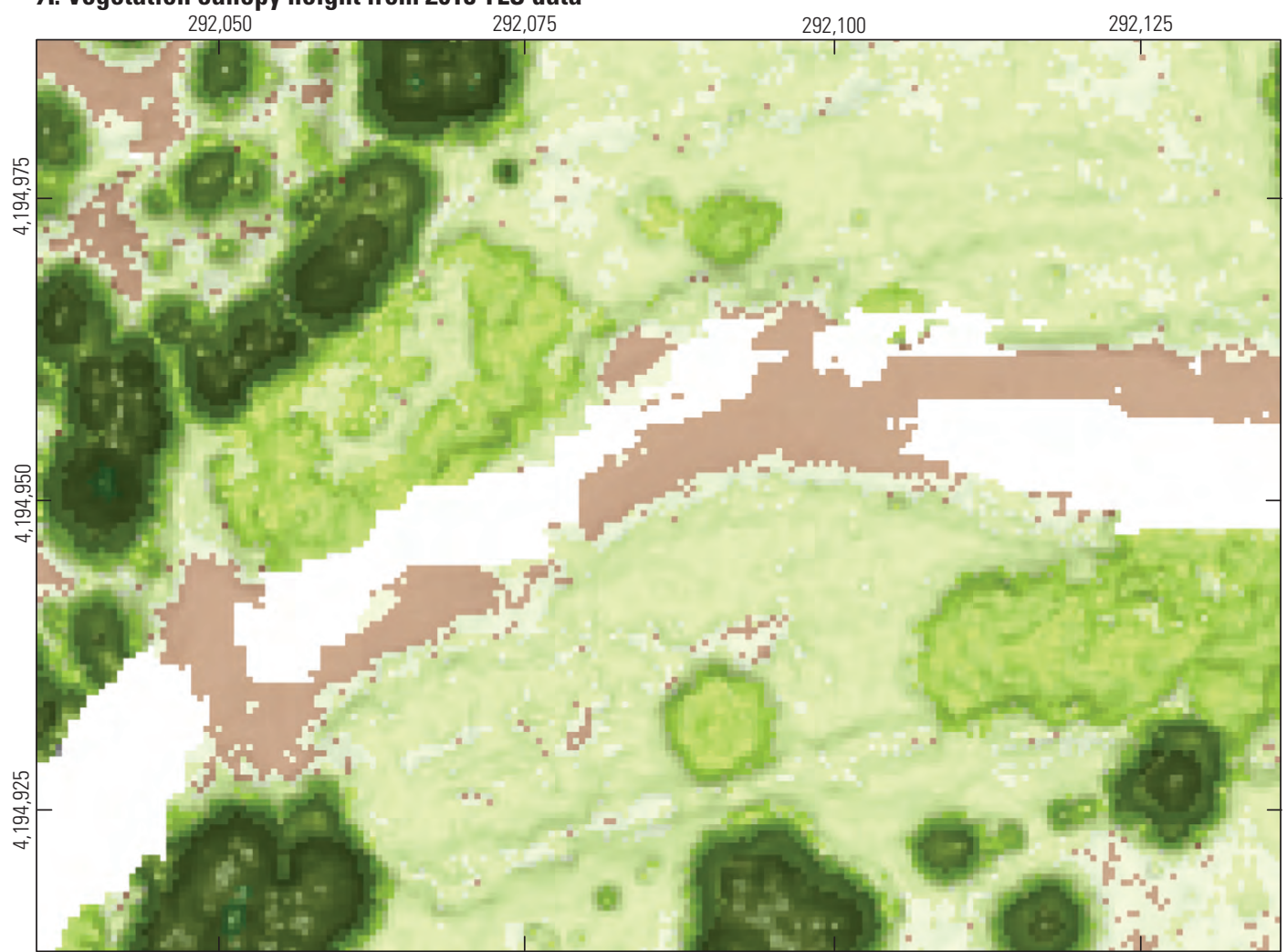

\section{EXPLANATION}

Canopy height, in meters

$<0.1$

0.1 to 0.25

0.25 to 1

1 to 2

2 to 4

4 to 10

10 to 20

20 to 30

30 to 50

B. Presence of streambank willows and other meadow vegetation from 2018 TLS data

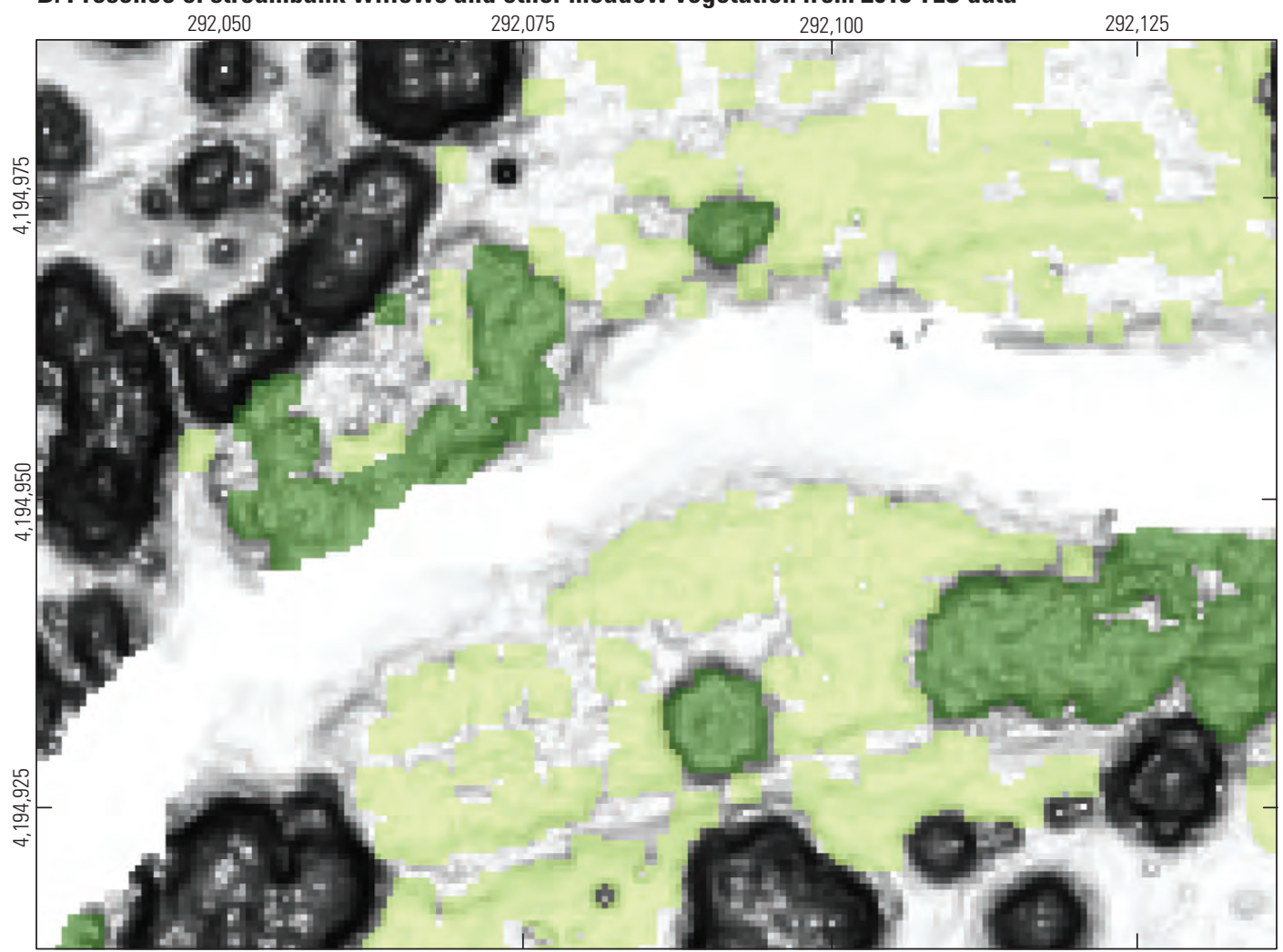

EXPLANATION

Canopy height, in meters

0.25 to 1 -Short vegetation

1 to 4 -Mostly willows

Universal Transverse Mercator, zone 11 North; North American Datum of 1983

Figure 13. Lidar-derived maps of vegetation at erosion zone 2. Data are from 2018 terrestrial laser scanning (TLS). $A$, shows a semitransparent canopy-height model over full-feature slopeshade. $B$, shows a map of vegetation most likely to be streambank willows and meadow vegetation. 
Table 4. Estimates of erosion and deposition at erosion zone 2 along Tuolumne River.

[---, no data; DEM, digital elevation model; DoD, DEMs of difference; $\mathrm{m}$, meter; $\mathrm{m}^{2}$, square meter; $\mathrm{m}^{3}$, cubic meter]

\begin{tabular}{|c|c|c|c|c|c|c|c|c|}
\hline \multirow[b]{2}{*}{$\begin{array}{l}\text { Erosion } \\
\text { zone }\end{array}$} & \multirow[b]{2}{*}{$\begin{array}{l}\text { Surveyed } \\
\text { interval }\end{array}$} & \multirow[b]{2}{*}{$\begin{array}{c}\text { Streambank } \\
\text { or bar }\end{array}$} & \multicolumn{2}{|c|}{ From DEM change mapping } & \multicolumn{4}{|c|}{ From streambank mapping } \\
\hline & & & $\begin{array}{l}\text { Area of data } \\
\text { in zone }\left(\mathrm{m}^{2}\right)\end{array}$ & $\begin{array}{l}\text { Volume change } \\
\text { from } \operatorname{DoD}\left(\mathrm{m}^{3}\right)\end{array}$ & $\begin{array}{c}\text { Active } \\
\text { streambank } \\
\text { length }(\mathrm{m})\end{array}$ & $\begin{array}{c}\text { Bank } \\
\text { height }(m)\end{array}$ & $\begin{array}{c}\text { Average bank } \\
\text { retreat }(\mathrm{m})\end{array}$ & $\begin{array}{c}\text { Volume change } \\
\text { from streambank } \\
\text { mapping }\left(\mathrm{m}^{3}\right)\end{array}$ \\
\hline 2 & 2006-2016 & Bank & 250 & $c-144.51$ & 40 & 1.40 & 1.0 & -56.0 \\
\hline 2 & 2006-2017 & Bar & 179 & a27.01 & --- & --- & --- & --- \\
\hline 2 & $2006-2018$ & Bank & 239 & $\mathrm{c}-184.41$ & --- & --- & --- & --- \\
\hline 2 & 2016-2017 & Bar & 53 & b3.1 & --- & --- & --- & --- \\
\hline 2 & 2016-2017 & Bank & 120 & $\mathrm{~b}-2.6$ & 19 & 1.40 & 1.20 & -31.9 \\
\hline 2 & $2017-2018$ & Bar & 52 & ${ }^{b}-1.1$ & --- & --- & --- & --- \\
\hline 2 & 2017-2018 & Bank & 125 & $\mathrm{~b}-33.5$ & 18 & 1.40 & 0.8 & -20.2 \\
\hline
\end{tabular}

${ }^{a}$ Calculated from 50-cm-resolution digital elevation models at 4-cm level of detection.

${ }^{\mathrm{b}}$ Calculated from 10-cm-resolution digital elevation models at 2-cm level of detection.

'Likely an overestimate owing to issue with dense vegetation on 2006 ALSM survey. See figure 9.

\section{Erosion Zone 3}

Erosion zone 3 is immediately upstream of the Soda Springs footbridge (fig. 2) on the south side of the river. It is opposite of a large point bar (fig. 14). The streambank is eroding a grass-covered meadow surface and underlying fluvial deposits (figs. 15 and 16). The streambank in this area retreated an average of $1.1 \mathrm{~m}$ between 2006 and 2016 (table 5). The streambank position did not retreat a measurable distance between 2016 and 2018. Between 2006 and 2016 the adjacent point bar increased in volume by about $33 \mathrm{~m}^{3}$ and the streambank zone was eroded between about 37 and $52 \mathrm{~m}^{3}$, indicating a rough balance between sediment erosion and deposition. Between 2016 and 2018 sediment deposition on the point bar of about $68 \mathrm{~m}^{3}$ far exceeded the removal of about $12 \mathrm{~m}^{3}$ of sediment from below the stable streambank. For the full study period, sediment deposition on the bar of about $117 \mathrm{~m}^{3}$ exceeded apparent erosion of between 47 and $53 \mathrm{~m}^{3}$.

Table 5. Estimates of erosion and deposition at erosion zone 3 along Tuolumne River.

[---, no data; DEM, digital elevation model; DoD, DEMs of difference; $\mathrm{m}$, meter; $\mathrm{m}^{2}$, square meter; $\mathrm{m}^{3}$, cubic meter]

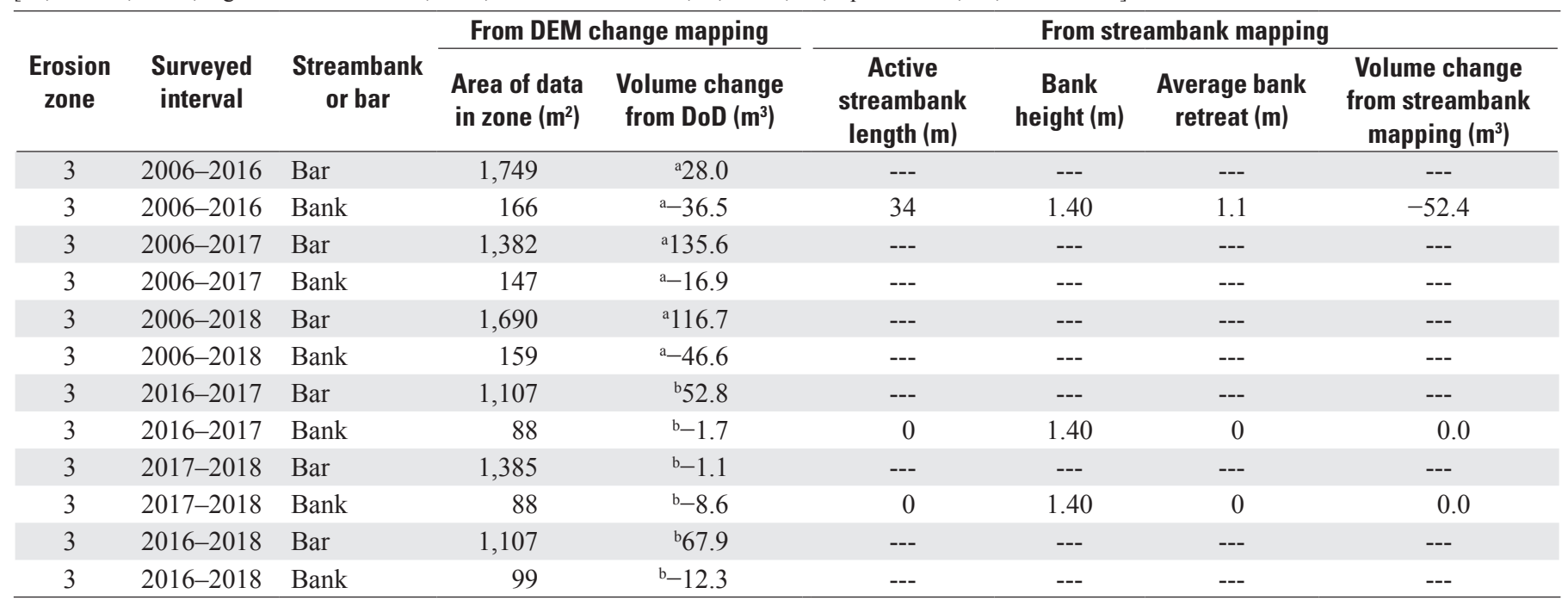

${ }^{\mathrm{a}}$ Calculated from $50-\mathrm{cm}-$ resolution digital elevation models at 4-cm level of detection.

${ }^{\mathrm{b}}$ Calculated from $10-\mathrm{cm}$-resolution digital elevation models at $2-\mathrm{cm}$ level of detection. 


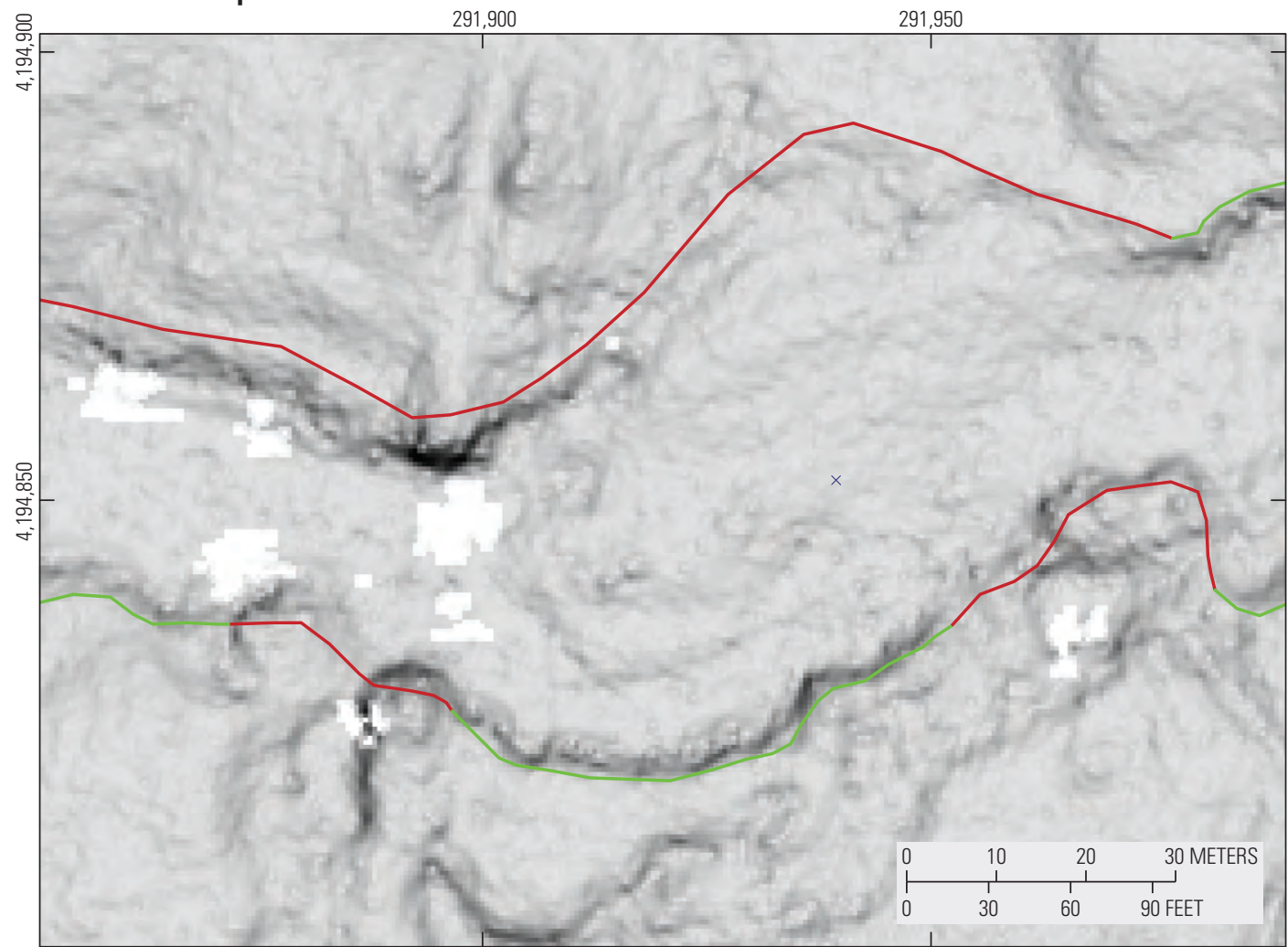

\section{EXPLANATION}

2006 streambanks

_ Indistinct/stable

- Steep/active

\section{B. Landscape change from 2006-16 on 2016 TLS slopeshade}

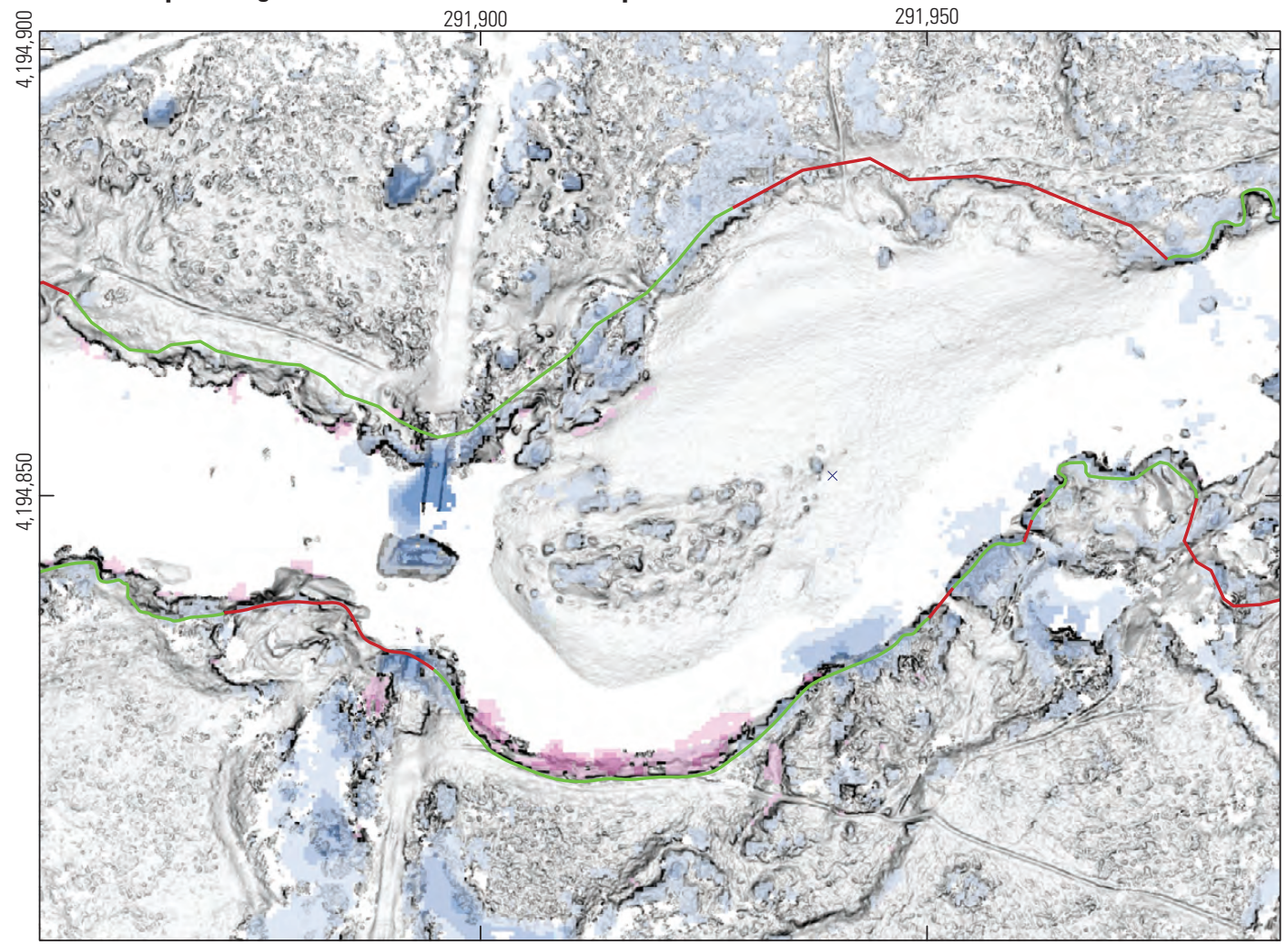

\section{EXPLANATION}

Elevation change, in meters

\section{4 to 2}

2 to 1

1 to 0.5

0.5 to 0.2

0.2 to -0.2

-0.2 to -0.5

-0.5 to -1

-1 to -2

-2 to -6

2016 streambanks

_- Indistinct/stable

Steep/active

Universal Transverse Mercator, zone 11 North; North American Datum of 1983

Figure 14. Lidar-derived maps showing location and classification of stream banks at erosion zone 2. A, 2006 airborne laser swath mapping (ALSM) bare-earth slopeshade with mapped streambanks. B, 2016 terrestrial laser scanning (TLS) bare-earth slopeshade. C, 2017 TLS bare-earth slopeshade. D, 2018 TLS bare-earth slopeshade. Colors indicate geomorphic change, and lines are mapped streambanks. 

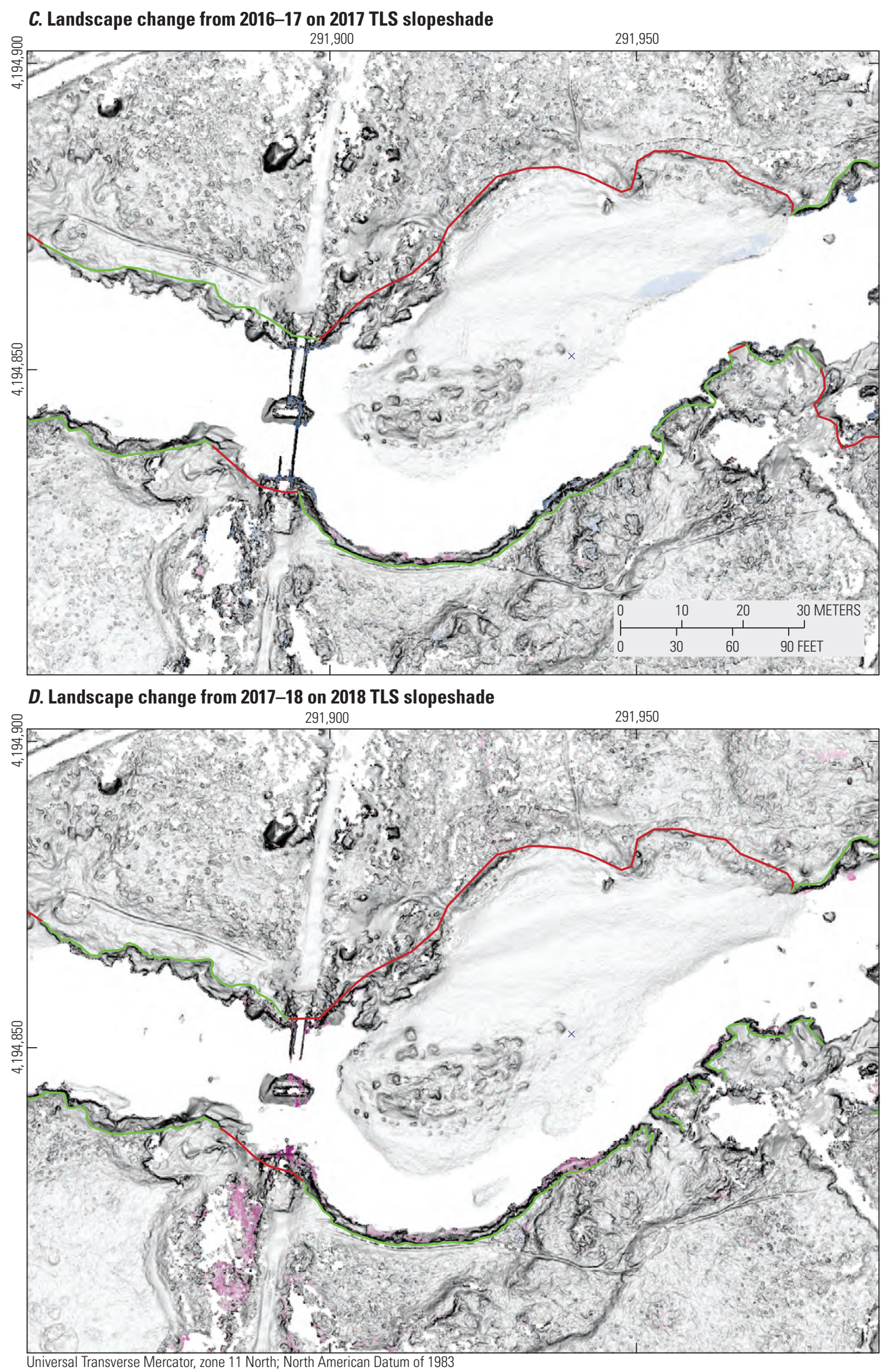

\section{EXPLANATION}

Elevation change, in meters

4 to 2

2 to 1

1 to 0.5

0.5 to 0.2

0.2 to -0.2

-0.2 to -0.5

-0.5 to -1

-1 to -2

-2 to -6

2018 streambanks

_- Indistinct/stable Steep/active

Figure 14.-Continued 


\section{A. Vegetation canopy height from 2018 TLS data}

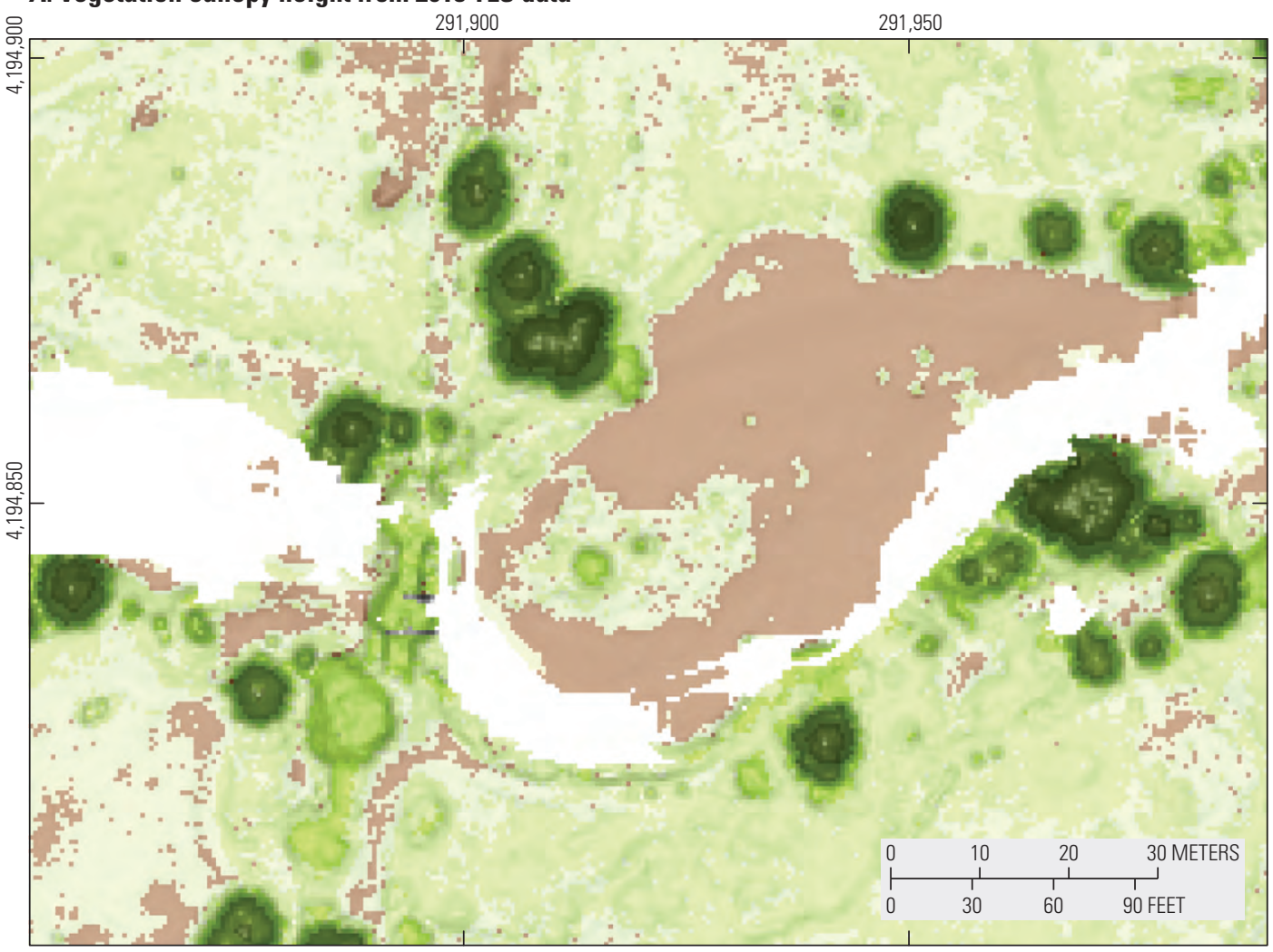

EXPLANATION

Canopy height, in meters

$<0.1$

0.1 to 0.25

0.25 to 1

1 to 2

2 to 4

4 to 10

10 to 20

20 to 30

30 to 50

\section{B. Presence of streambank willows and other meadow vegetation from 2018 TLS data}

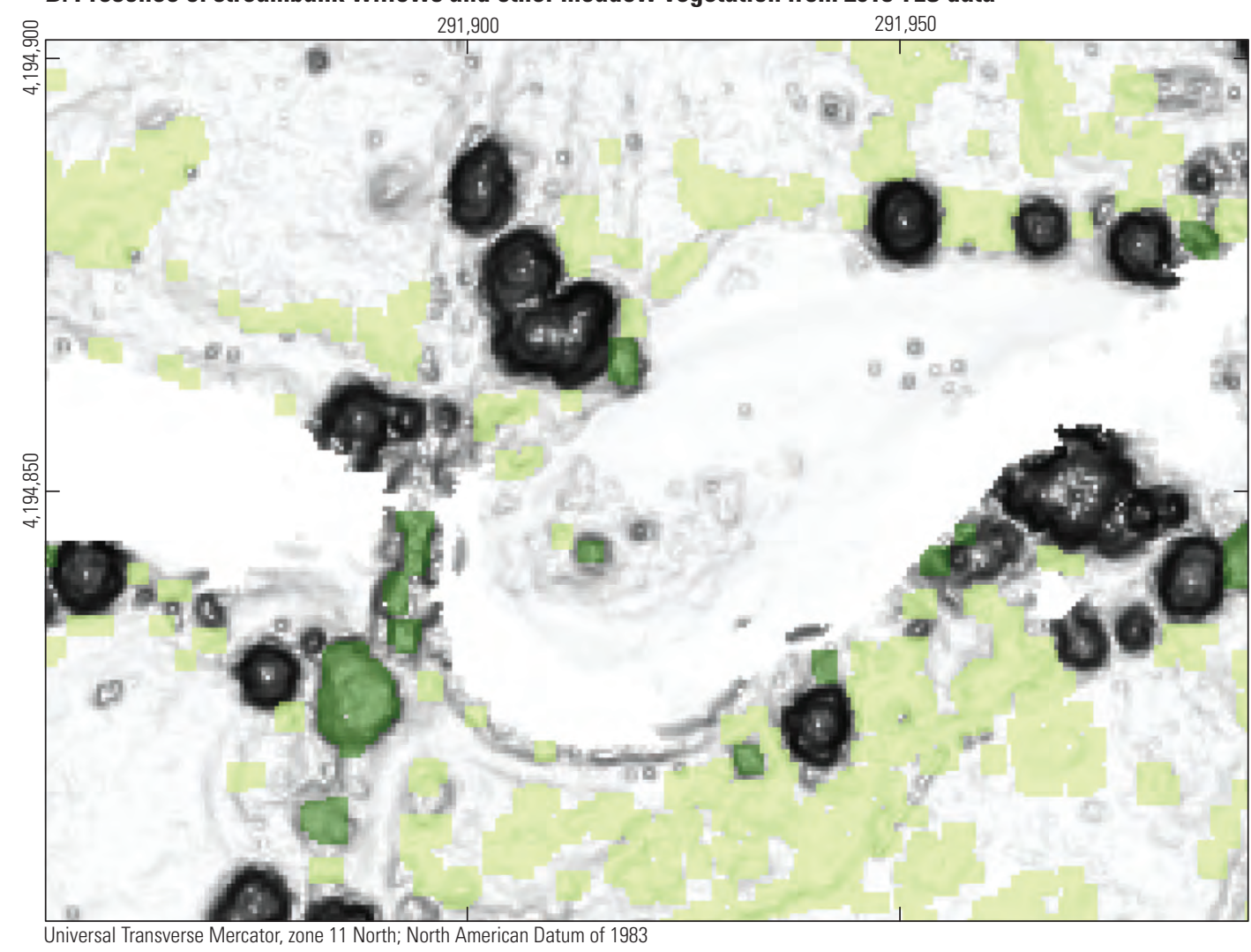

EXPLANATION

Canopy height, in meters

0.25 to 1 -Short vegetation

1 to 4 -Mostly willows

Figure 15. Lidar-derived maps of vegetation at erosion zone 3. Data are from 2018 terrestrial laser scanning (TLS). $A$, shows a semitransparent canopy-height model over full-feature slopeshade. $B$, shows a map of vegetation most likely to be streambank willows and meadow vegetation. 

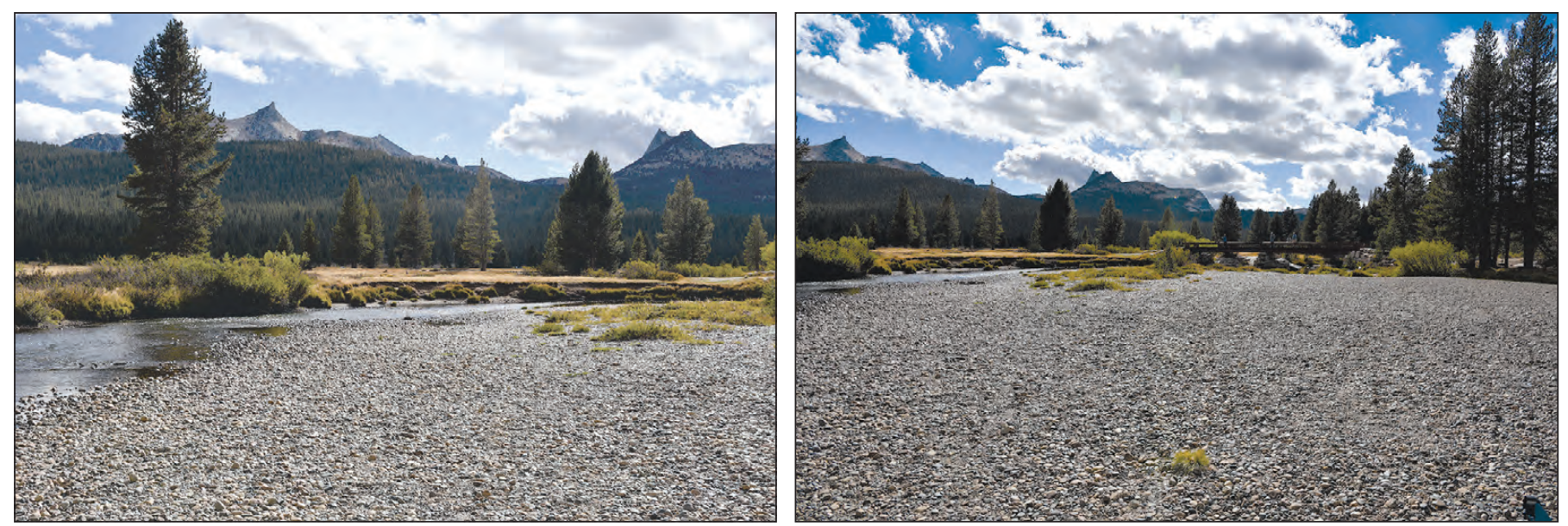

Figure 16. U.S. Geological Survey photographs of erosion zone 3, taken in 2016.

\section{Erosion Zone 4}

Erosion zone 4 is a broad, arcuate bend in the river at which the length of the retreating streambank is as great as $165 \mathrm{~m}$ (fig. 17). The streambank in this area is eroding a grass-covered surface underlain by sandy to gravelly fluvial material. The point bar hosts many willows (fig. 18). The failure mechanism in which cantilevered blocks of soil fail by erosion of weaker underlying fluvial sediment during floods is particularly apparent in this area (fig. 19). From 2006 to 2016 streambank erosion of about 239-321 $\mathrm{m}^{3}$ exceeded the about $92 \mathrm{~m}^{3}$ of sediment deposition on the adjacent point bar (table 6). During this time, the streambank retreated an average of $1.1 \mathrm{~m}$ over $165 \mathrm{~m}$ of length along the river. From 2016 to 2017, over approximately the same length, the streambank retreated an average of $1.3 \mathrm{~m}$, then retreated an average of about $0.27 \mathrm{~m}$ over a shorter $110 \mathrm{~m}$ of length along the river between 2017 and 2018. From 2016 to 2018, about $206 \mathrm{~m}^{3}$ of sediment was deposited in this zone, this exceeded the $107 \mathrm{~m}^{3}$ of sediment removed from the streambank as measure in the DoD; when estimated volumetrically based on streambank retreat, as much as about $345 \mathrm{~m}^{3}$ of sediment was removed or temporarily stored as slump blocks below the streambank crest. Over the entire study period, 2006-2018, sediment deposition on the point bar was about $322 \mathrm{~m}^{3}$. Erosion over the full study period was between 390 and $580 \mathrm{~m}^{3}$, indicating that this zone is eroding its streambank somewhat faster than deposition is occurring on the large point bar on the inside bend of the river, though both processes are occurring at a relatively high rate.

Table 6. Estimates of erosion and deposition at erosion zone 4 along Tuolumne River.

[---, no data; DEM, digital elevation model; DoD, DEMs of difference; $\mathrm{m}$, meter; $\mathrm{m}^{2}$, square meter; $\mathrm{m}^{3}$, cubic meter]

\begin{tabular}{|c|c|c|c|c|c|c|c|c|}
\hline \multirow[b]{2}{*}{$\begin{array}{c}\text { Erosion } \\
\text { zone }\end{array}$} & \multirow[b]{2}{*}{$\begin{array}{l}\text { Surveyed } \\
\text { interval }\end{array}$} & \multirow[b]{2}{*}{$\begin{array}{c}\text { Streambank } \\
\text { or bar }\end{array}$} & \multicolumn{2}{|c|}{ From DEM change mapping } & \multicolumn{4}{|c|}{ From streambank mapping } \\
\hline & & & $\begin{array}{l}\text { Area of data } \\
\text { in zone }\left(\mathrm{m}^{2}\right)\end{array}$ & $\begin{array}{l}\text { Volume change } \\
\text { from } \mathrm{DoD}\left(\mathrm{m}^{3}\right)\end{array}$ & $\begin{array}{c}\text { Active } \\
\text { streambank } \\
\text { length (m) }\end{array}$ & $\begin{array}{c}\text { Bank } \\
\text { height }(\mathrm{m})\end{array}$ & $\begin{array}{c}\text { Average bank } \\
\text { retreat }(\mathrm{m})\end{array}$ & $\begin{array}{c}\text { Volume change } \\
\text { from streambank } \\
\text { mapping }\left(\mathrm{m}^{3}\right)\end{array}$ \\
\hline 4 & 2006-2016 & Bank & 1,095 & a -320.7 & 165 & 1.45 & 1.1 & -239.3 \\
\hline 4 & $2006-2017$ & Bar & 2,515 & a343.5 & --- & --- & --- & --- \\
\hline 4 & 2006-2018 & Bank & 1,044 & a-389.9 & --- & --- & --- & --- \\
\hline 4 & 2016-2017 & Bar & 2,158 & ${ }^{\mathrm{b}} 164.8$ & --- & --- & --- & --- \\
\hline 4 & 2016-2017 & Bank & 547 & b-21.9 & 160 & 1.45 & 1.3 & -301.6 \\
\hline 4 & $2017-2018$ & Bar & 2,130 & ${ }^{\mathrm{b}} 11.5$ & --- & --- & --- & --- \\
\hline 4 & $2017-2018$ & Bank & 505 & b-63.9 & 110 & 1.45 & 0.27 & -43.1 \\
\hline
\end{tabular}

${ }^{\mathrm{a}}$ Calculated from $50-\mathrm{cm}$-resolution digital elevation models at $4-\mathrm{cm}$ level of detection.

${ }^{\mathrm{b}}$ Calculated from 10-cm-resolution digital elevation models at 2-cm level of detection. 
A. 2006 ALSM slopeshade

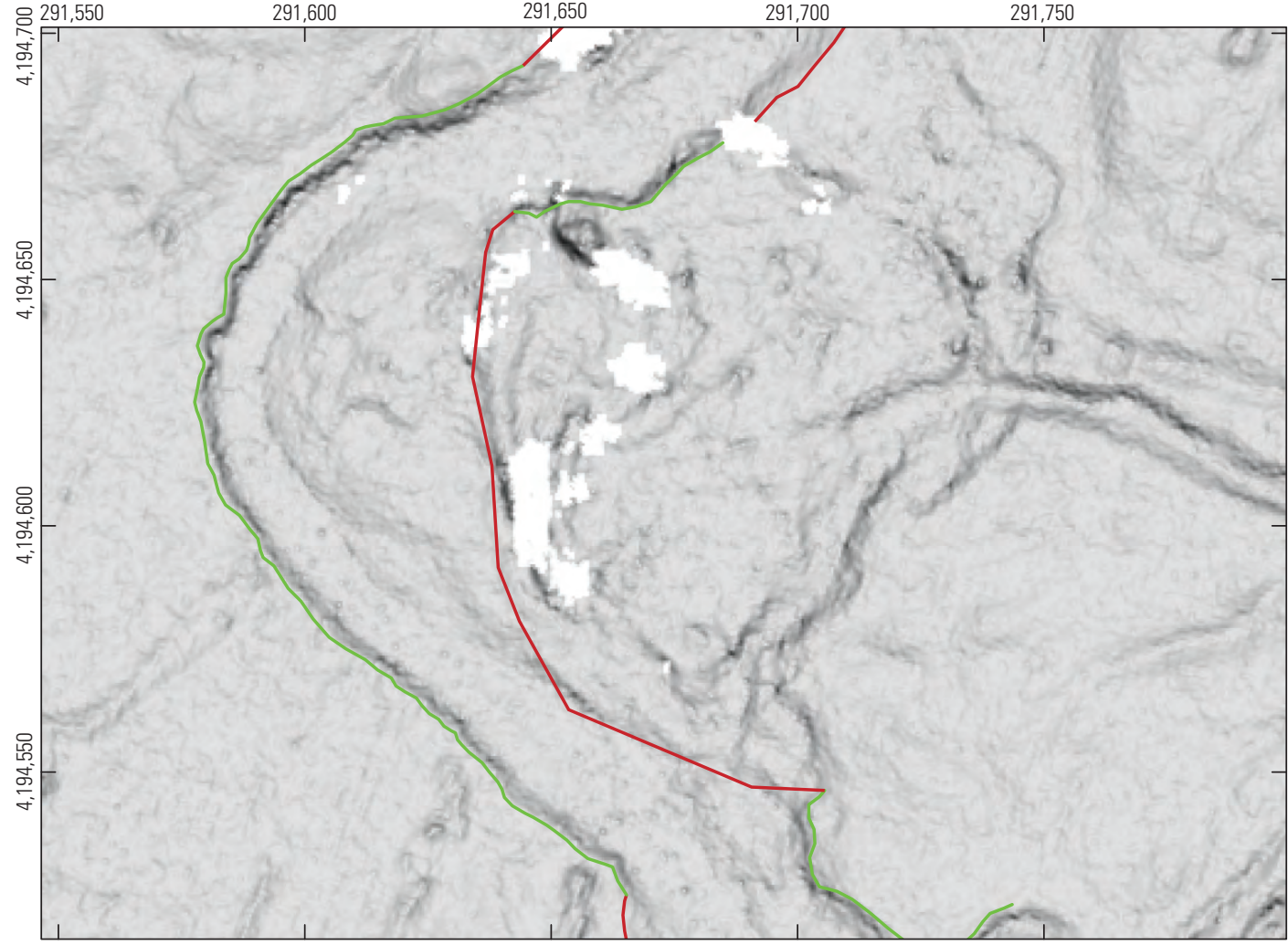

B. Landscape change from 2006-16 on 2016 TLS slopeshade

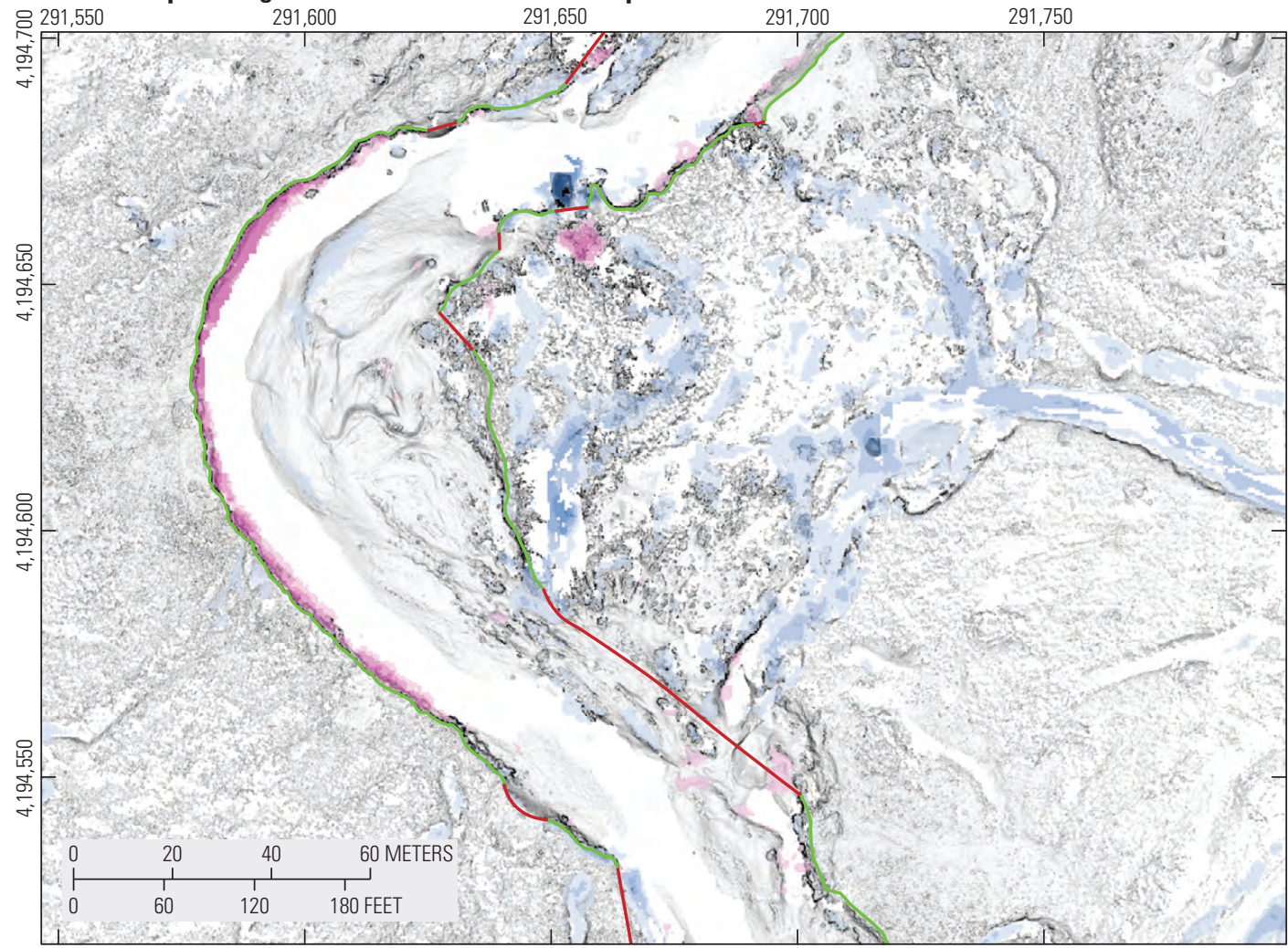

Universal Transverse Mercator, zone 11 North; North American Datum of 1983

\section{EXPLANATION}

2006 streambanks

_ Indistinct/stable

Steep/active

Figure 17. Lidar-derived maps showing location and classification of stream banks at erosion zone 4. A, 2006 airborne laser swath mapping (ALSM) bare-earth slopeshade with mapped streambanks. B, 2016 terrestrial laser scanning (TLS) bare-earth slopeshade. C, 2017 TLS bare-earth slopeshade. D, 2018 TLS bare-earth slopeshade. Colors indicate geomorphic change and lines are mapped streambanks. 
C. Landscape change from 2016-17 on 2017 TLS slopeshade

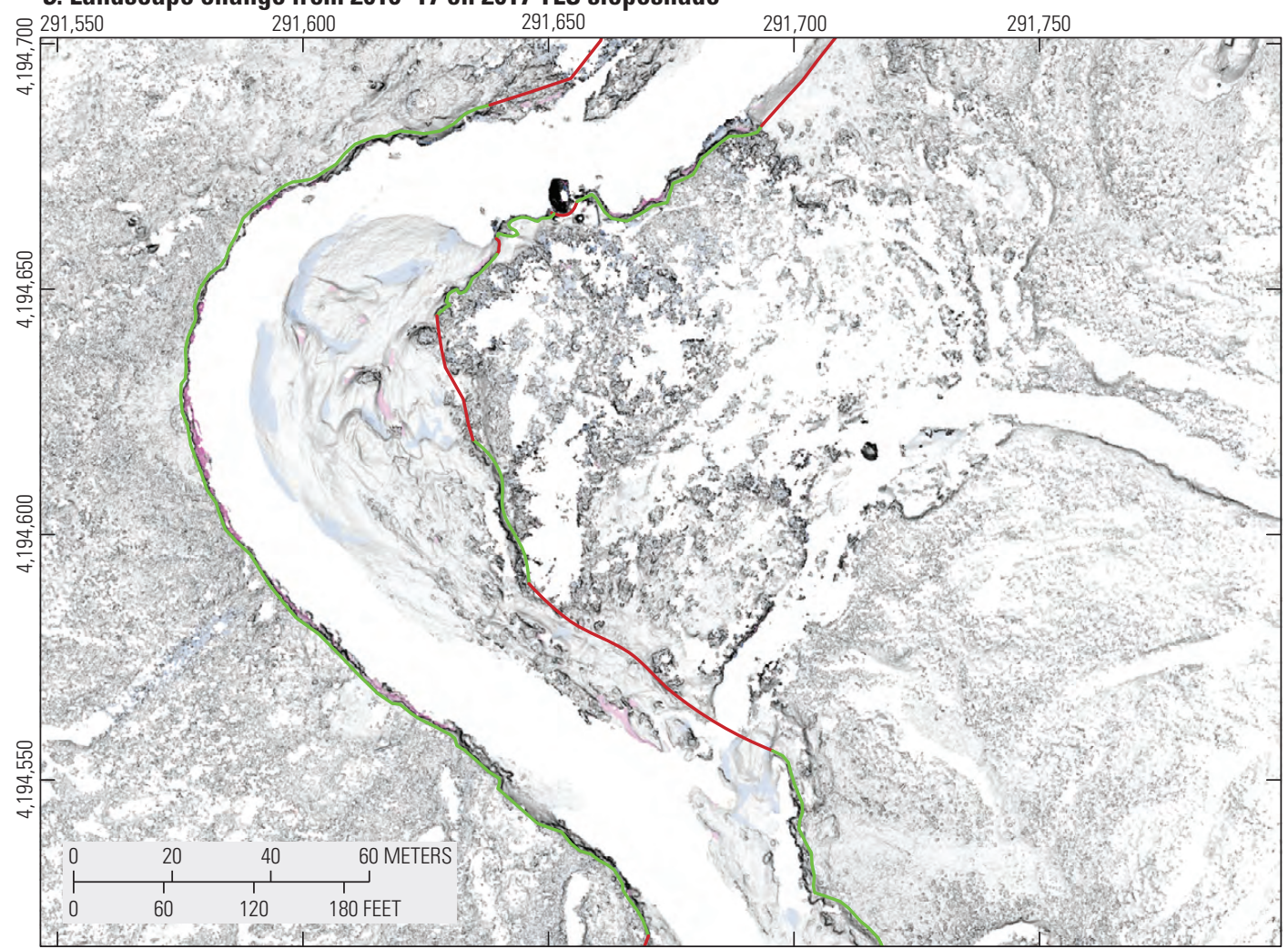

\section{EXPLANATION}

Elevation change, in meters

\begin{tabular}{|l|}
4 to 2 \\
2 to 1 \\
1 to 0.5 \\
0.5 to 0.2 \\
0.2 to -0.2 \\
-0.2 to -0.5 \\
-0.5 to -1 \\
-1 to -2 \\
-2 to -6
\end{tabular}

2017 streambanks

Indistinct/stable

- Steep/active

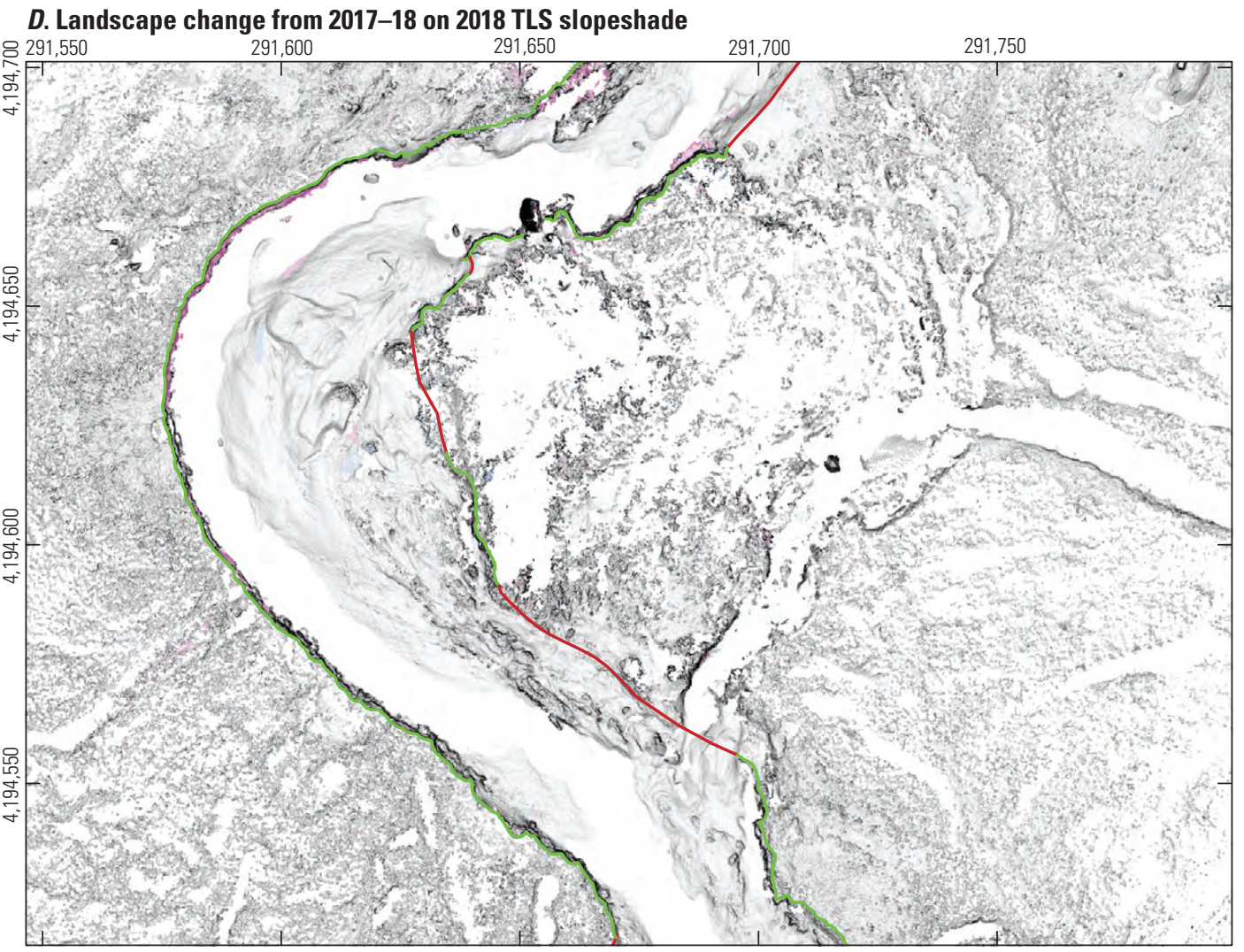

\section{EXPLANATION}

Elevation change, in meters

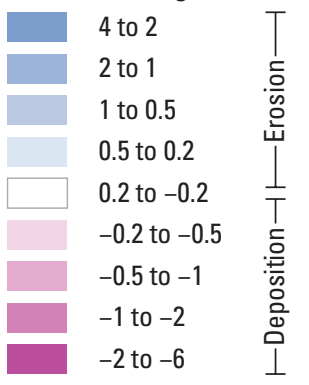

2018 streambanks

Indistinct/stable Steep/active

Universal Transverse Mercator, zone 11 North; North American Datum of 1983

Figure 17.-Continued 
A. Vegetation canopy height from 2018 TLS data

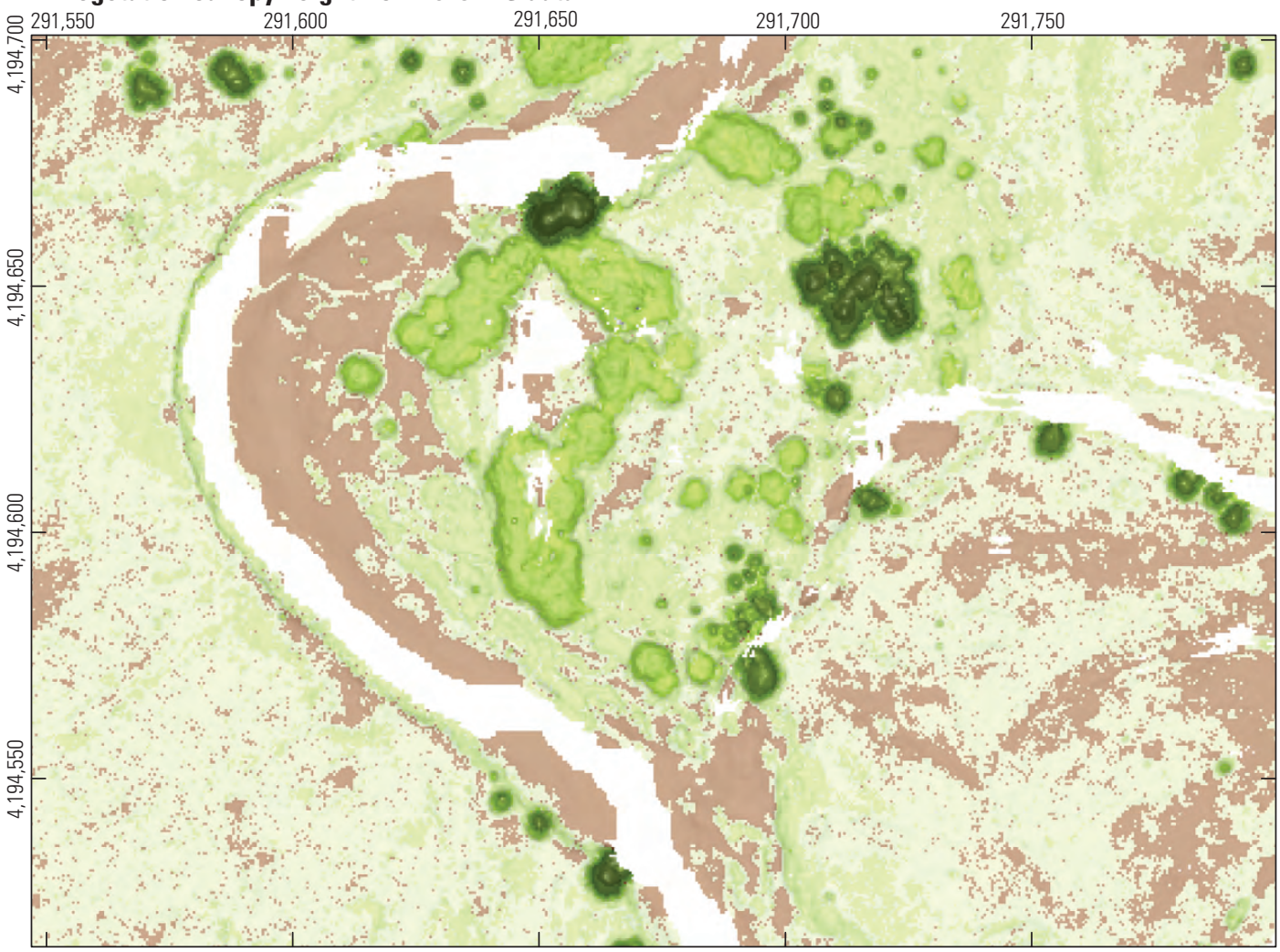

\section{EXPLANATION}

Canopy height, in meters $<0.1$

\section{1 to 0.25}

0.25 to 1

1 to 2

2 to 4

4 to 10

10 to 20

20 to 30

30 to 50

B. Presence of streambank willows and other meadow vegetation from 2018 TLS data

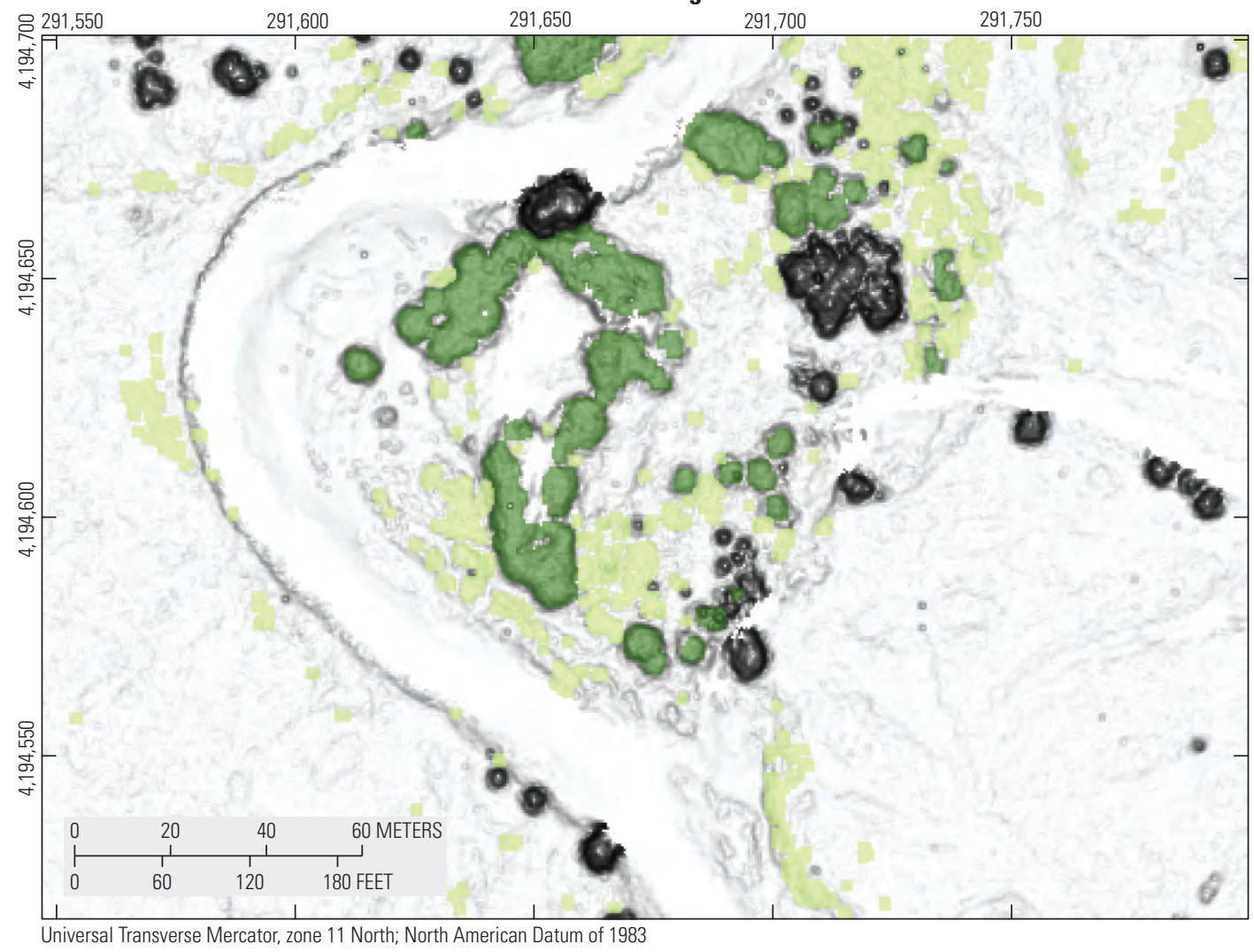

EXPLANATION

Canopy height, in meters

0.25 to 1 -Short vegetation

1 to $4-$ Mostly willows

Figure 18. Lidar-derived maps of vegetation at erosion zone 4. Data are from 2018 terrestrial laser scanning (TLS). $A$, shows a semitransparent canopy-height model over full-feature slopeshade. $B$, shows a map of vegetation most likely to be streambank willows and meadow vegetation. 

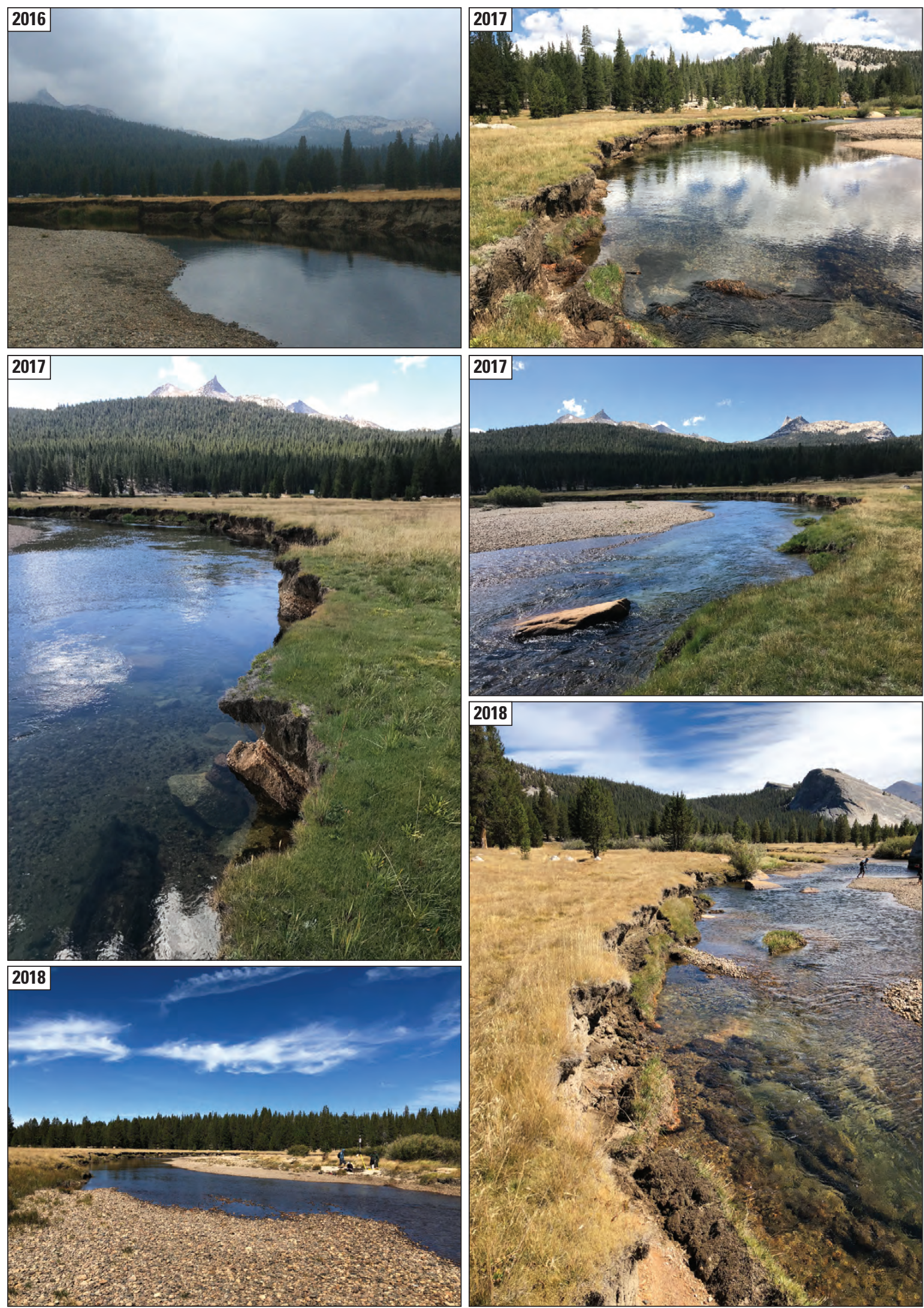

Figure 19. U.S. Geological Survey photographs of erosion zone 4, taken during 2016-2018. 


\section{Erosion Zone 5}

Erosion zone 5 is along a relatively straight section of the Tuolumne River. The eroding streambank is just less than $100 \mathrm{~m}$ long and is across from a large point/channel bar (fig. 20). The streambank is eroding a flat grass-covered surface with soil and fluvial sediments underlying it (figs. 21 and 22). The depositional bar hosts some willows. Between 2006 and 2016, the streambank retreated an average of about $1.1 \mathrm{~m}$, causing between about 137 and $153 \mathrm{~m}^{3}$ of erosion (table 7). During this time, the bar accumulated about $86 \mathrm{~m}^{3}$ of sediment.
In 2017, the streambank retreated an average of about $1.4 \mathrm{~m}$, and in 2018 it retreated and average of about $0.25 \mathrm{~m}$. From 2016 to 2018 , about $131 \mathrm{~m}^{3}$ of sediment was deposited in this zone. This exceeded erosion measured from the DoD $\left(51.5 \mathrm{~m}^{3}\right)$ but was less than estimated from the streambank position change $\left(\sim 180 \mathrm{~m}^{3}\right)$. For the entire study period of $2006-2018$, deposition on the bar of about $247 \mathrm{~m}^{3}$ exceeded streambank erosion as measured by the $\mathrm{DoD}\left(\sim 180 \mathrm{~m}^{3}\right)$ but was less than erosion as measured by streambank position alone $\left(\sim 317 \mathrm{~m}^{3}\right)$. The bar noticeably enlarged in the downstream direction from 2016 to 2018 (fig. 20).

Table 7. Estimates of erosion and deposition at erosion zone 5 along Tuolumne River.

[---, no data; DEM, digital elevation model; DoD, DEMs of difference; $\mathrm{m}$, meter; $\mathrm{m}^{2}$, square meter; $\mathrm{m}^{3}$, cubic meter]

\begin{tabular}{|c|c|c|c|c|c|c|c|c|}
\hline \multirow[b]{2}{*}{$\begin{array}{l}\text { Erosion } \\
\text { zone }\end{array}$} & \multirow[b]{2}{*}{$\begin{array}{l}\text { Surveyed } \\
\text { interval }\end{array}$} & \multirow[b]{2}{*}{$\begin{array}{c}\text { Streambank } \\
\text { or bar }\end{array}$} & \multicolumn{2}{|c|}{ From DEM change mapping } & \multicolumn{4}{|c|}{ From streambank mapping } \\
\hline & & & $\begin{array}{l}\text { Area of data } \\
\text { in zone }\left(\mathrm{m}^{2}\right)\end{array}$ & $\begin{array}{l}\text { Volume change } \\
\text { from } D_{0} D\left(\mathrm{~m}^{3}\right)\end{array}$ & $\begin{array}{c}\text { Active } \\
\text { streambank } \\
\text { length }(\mathrm{m})\end{array}$ & $\begin{array}{c}\text { Bank } \\
\text { height }(\mathrm{m})\end{array}$ & $\begin{array}{l}\text { Average bank } \\
\text { retreat }(\mathrm{m})\end{array}$ & $\begin{array}{c}\text { Volume change } \\
\text { from streambank } \\
\text { mapping }\left(\mathrm{m}^{3}\right)\end{array}$ \\
\hline 5 & 2006-2016 & Bank & 619 & a -152.5 & 96 & 1.30 & 1.10 & -137.3 \\
\hline 5 & 2006-2017 & Bar & 1,781 & a237.0 & --- & --- & --- & --- \\
\hline 5 & 2006-2018 & Bank & 471 & a -180.3 & --- & --- & --- & --- \\
\hline 5 & 2016-2017 & Bar & 1,413 & ${ }^{\mathrm{b}} 101.5$ & --- & --- & --- & --- \\
\hline 5 & 2016-2017 & Bank & 264 & b-39.1 & 95 & 1.30 & 1.40 & -172.9 \\
\hline 5 & $2017-2018$ & Bar & 1,547 & b 14.1 & --- & --- & --- & --- \\
\hline 5 & $2017-2018$ & Bank & 265 & b-14.7 & 22 & 1.30 & 0.25 & -7.2 \\
\hline
\end{tabular}

${ }^{a}$ Calculated from 50-cm-resolution digital elevation models at 4-cm level of detection.

${ }^{\mathrm{b}} \mathrm{Calculated}$ from 10-cm-resolution digital elevation models at 2-cm level of detection. 
A. 2006 ALSM slopeshade

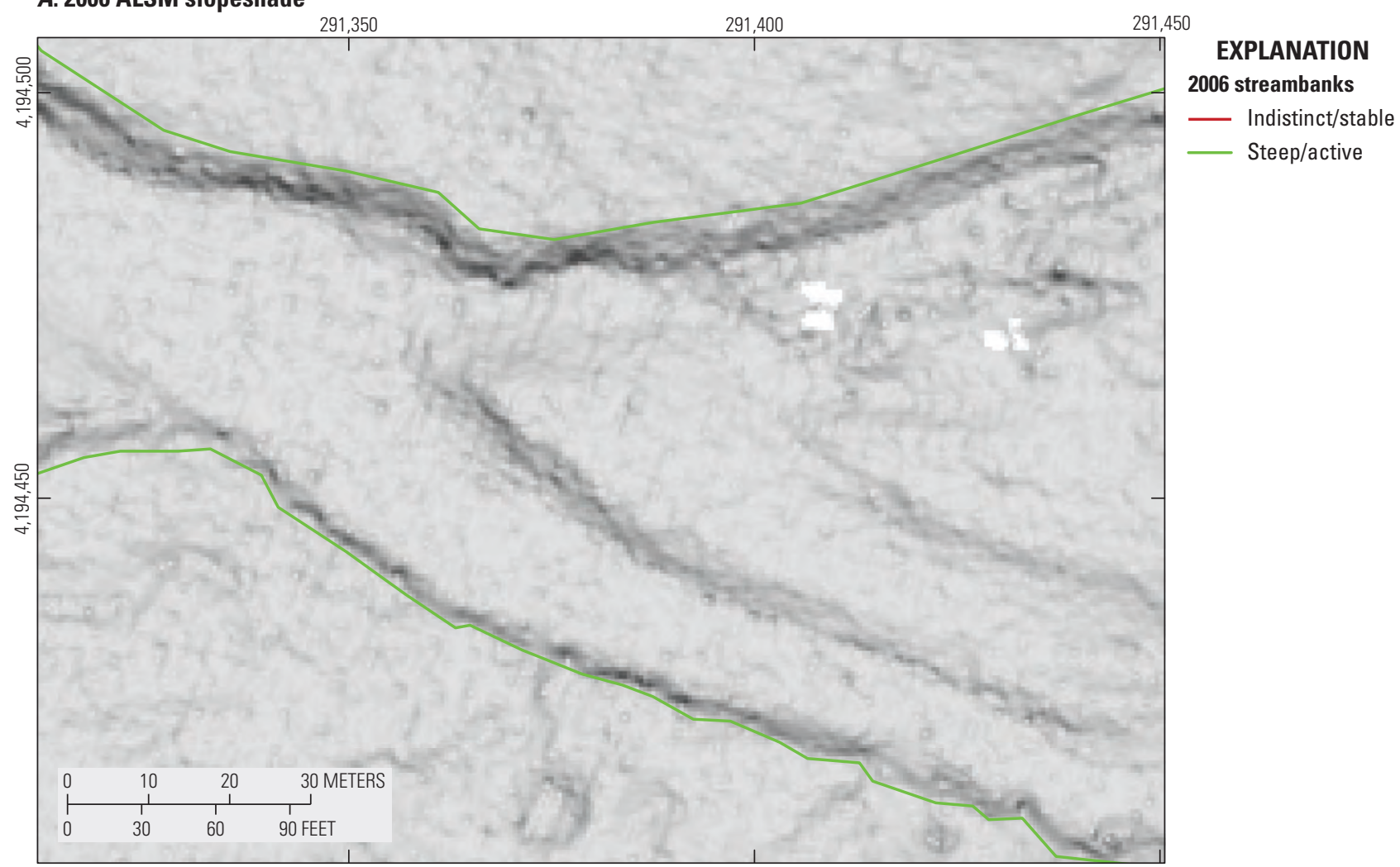

B. Landscape change from $2006-16$ on 2016 TLS slopeshade

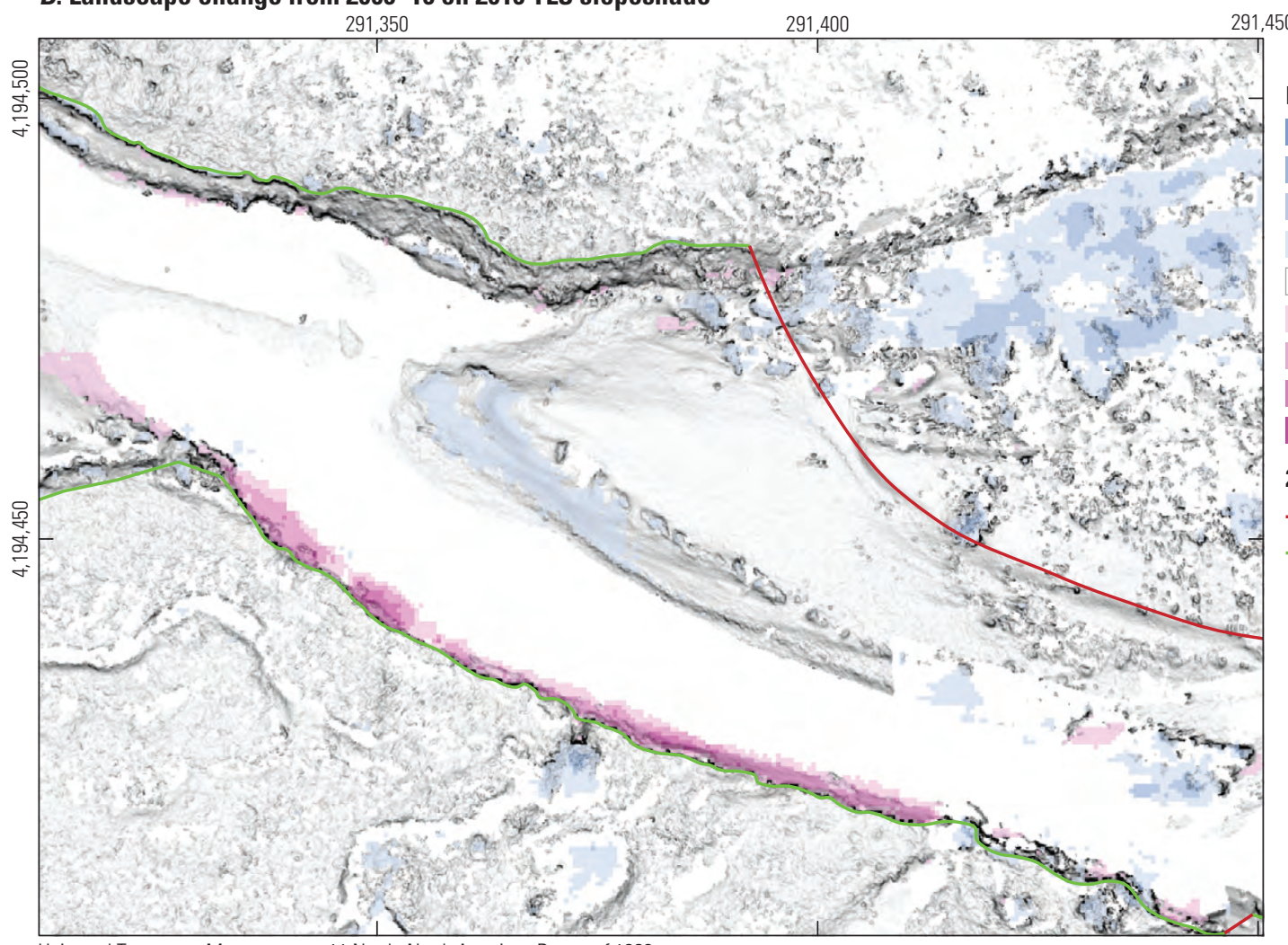

EXPLANATION

Elevation change, in meters

4 to 2

2 to 1

1 to 0.5

0.5 to 0.2

0.2 to -0.2

-0.2 to -0.5

-0.5 to -1

-1 to -2

-2 to -6

2016 streambanks

_ Indistinct/stable Steep/active

Universal Transverse Mercator, zone 11 North; North American Datum of 1983

Figure 20. Lidar-derived maps showing location and classification of stream banks at erosion zone 5. $A$, 2006 airborne laser swath mapping (ALSM) bare-earth slopeshade with mapped streambanks. B, 2016 terrestrial laser scanning (TLS) bare-earth slopeshade. C, 2017 TLS bare-earth slopeshade. D, 2018 TLS bare-earth slopeshade. Colors indicate geomorphic change and lines are mapped streambanks. 
C. Landscape change from 2016-17 on 2017 TLS slopeshade

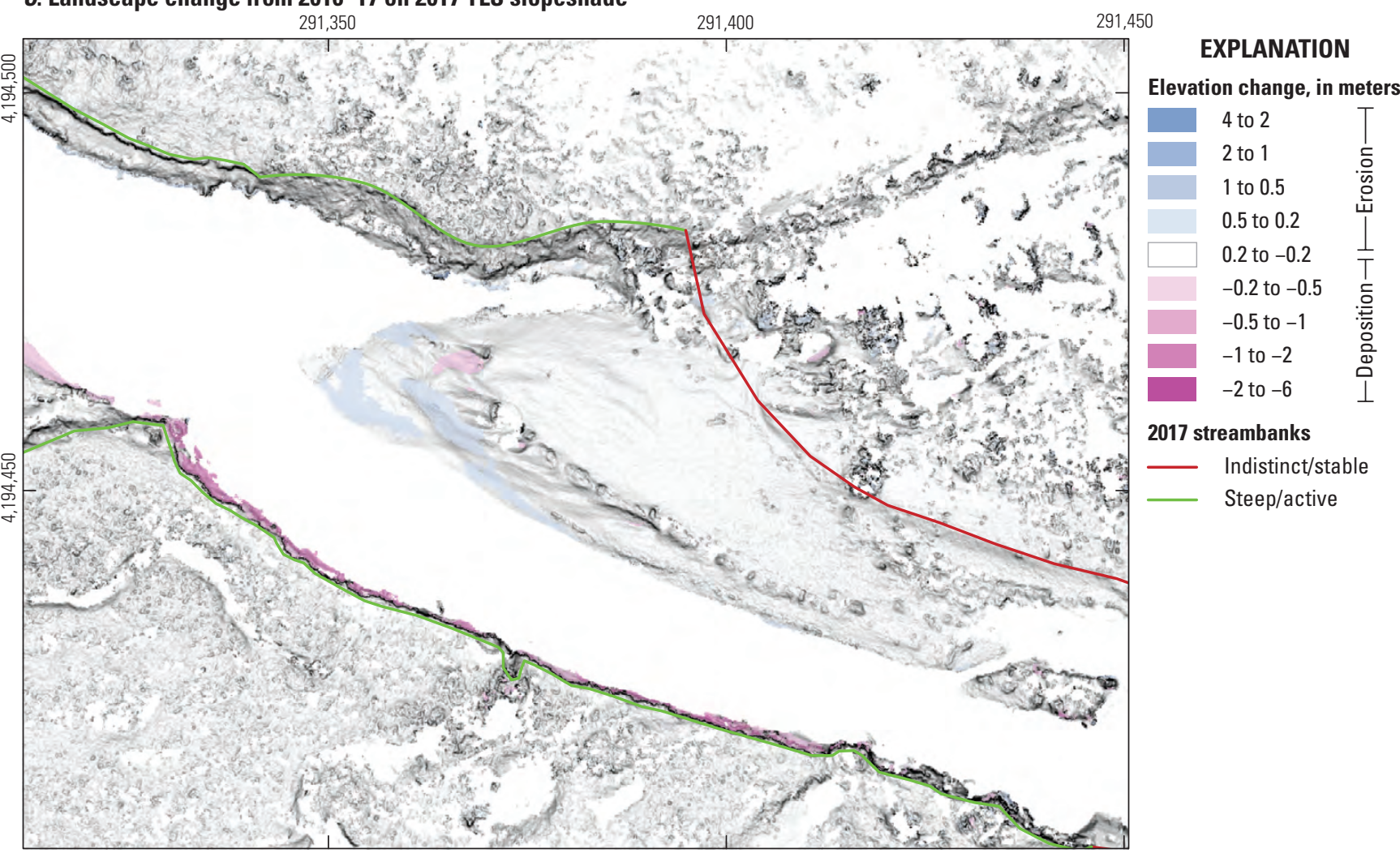

D. Landscape change from 2017-18 on 2018 TLS slopeshade

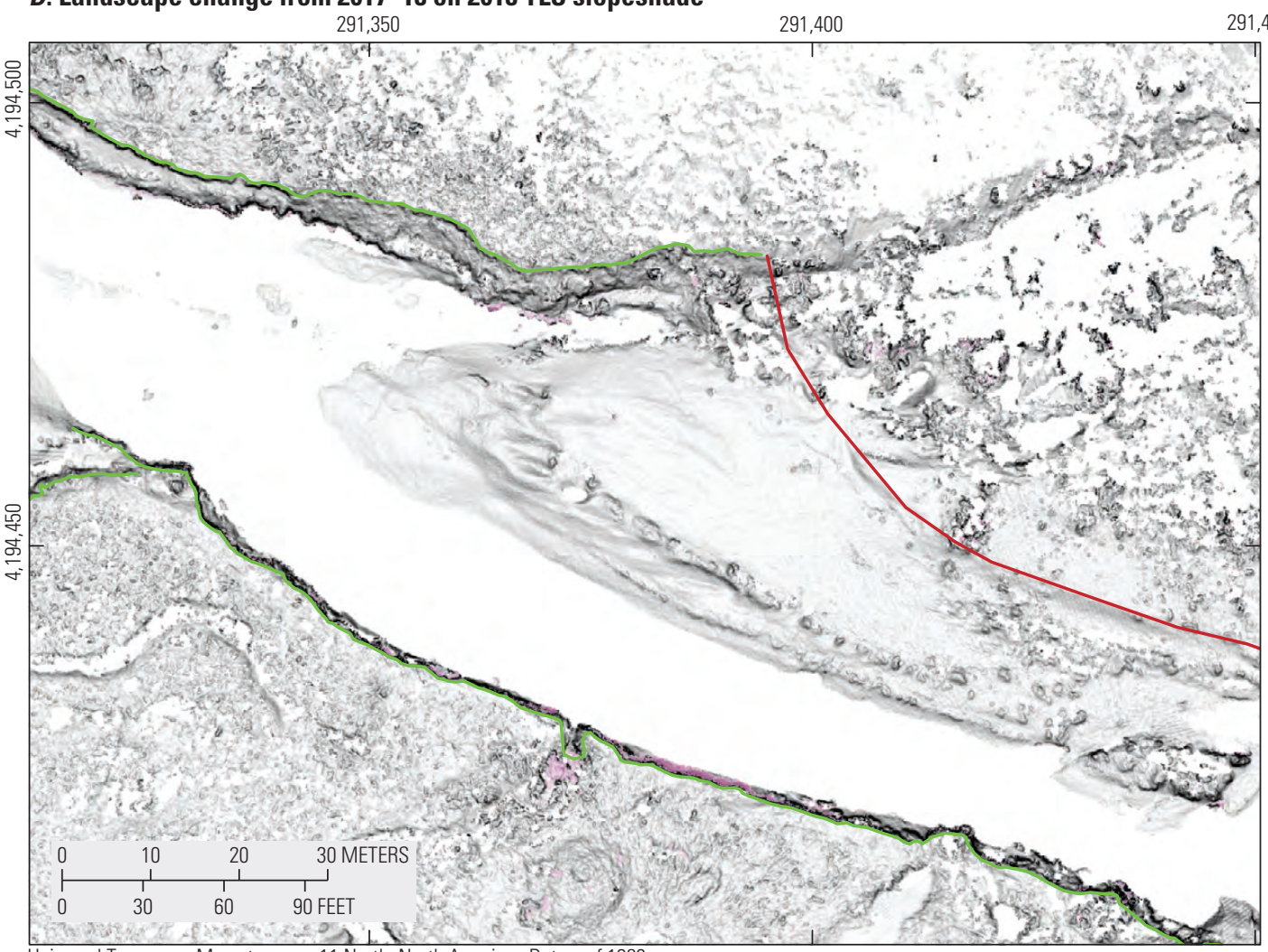

EXPLANATION

Elevation change, in meters

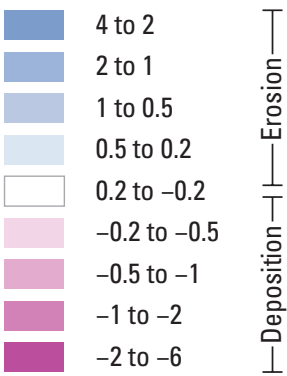

2018 streambanks

_- Indistinct/stable Steep/active

Figure 20.-Continued 
A. Vegetation canopy height from 2018 TLS data

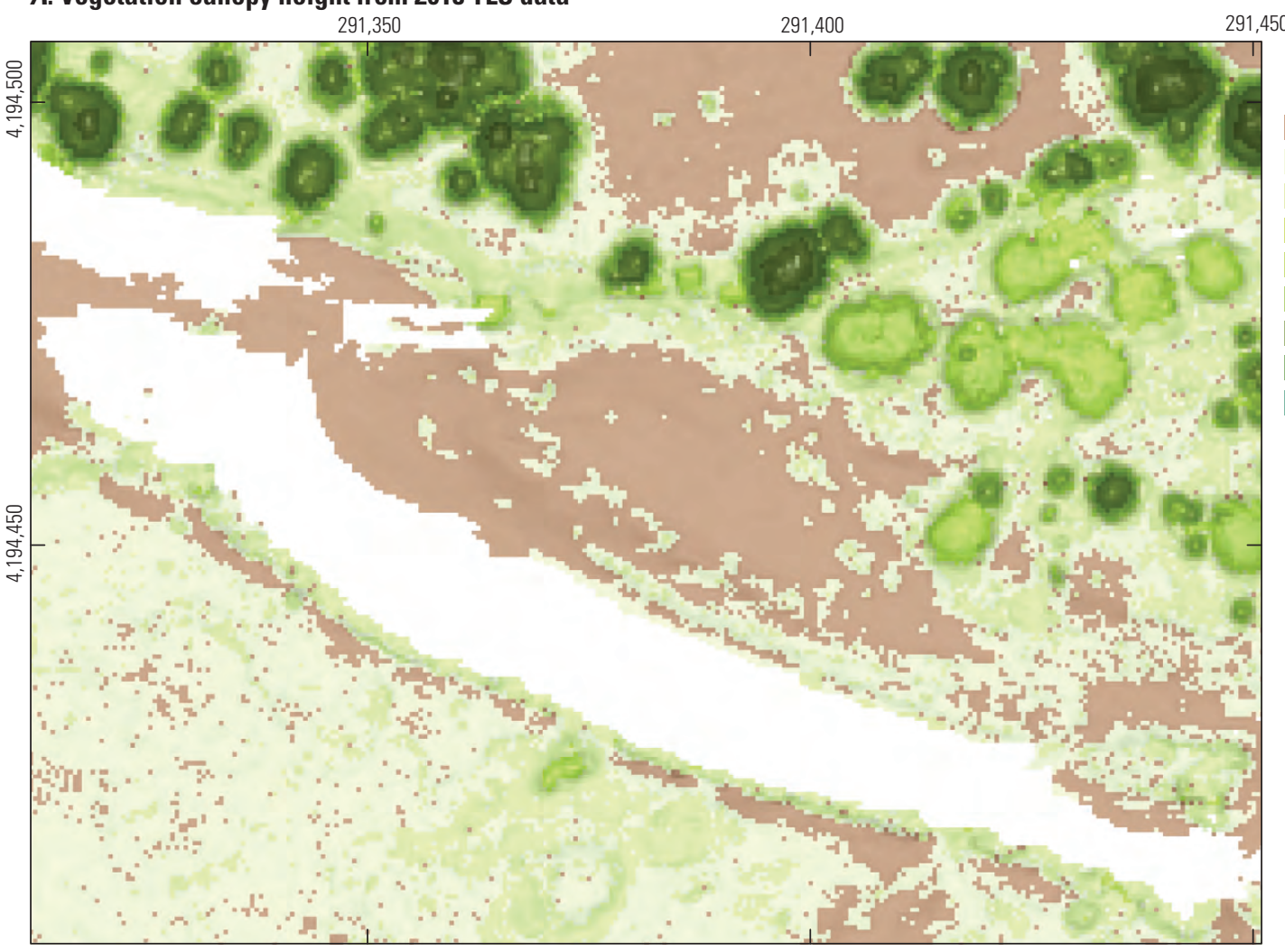

\section{EXPLANATION}

Canopy height, in meters $<0.1$

\section{1 to 0.25}

0.25 to 1

1 to 2

2 to 4

4 to 10

10 to 20

20 to 30

30 to 50

B. Presence of streambank willows and other meadow vegetation from 2018 TLS data

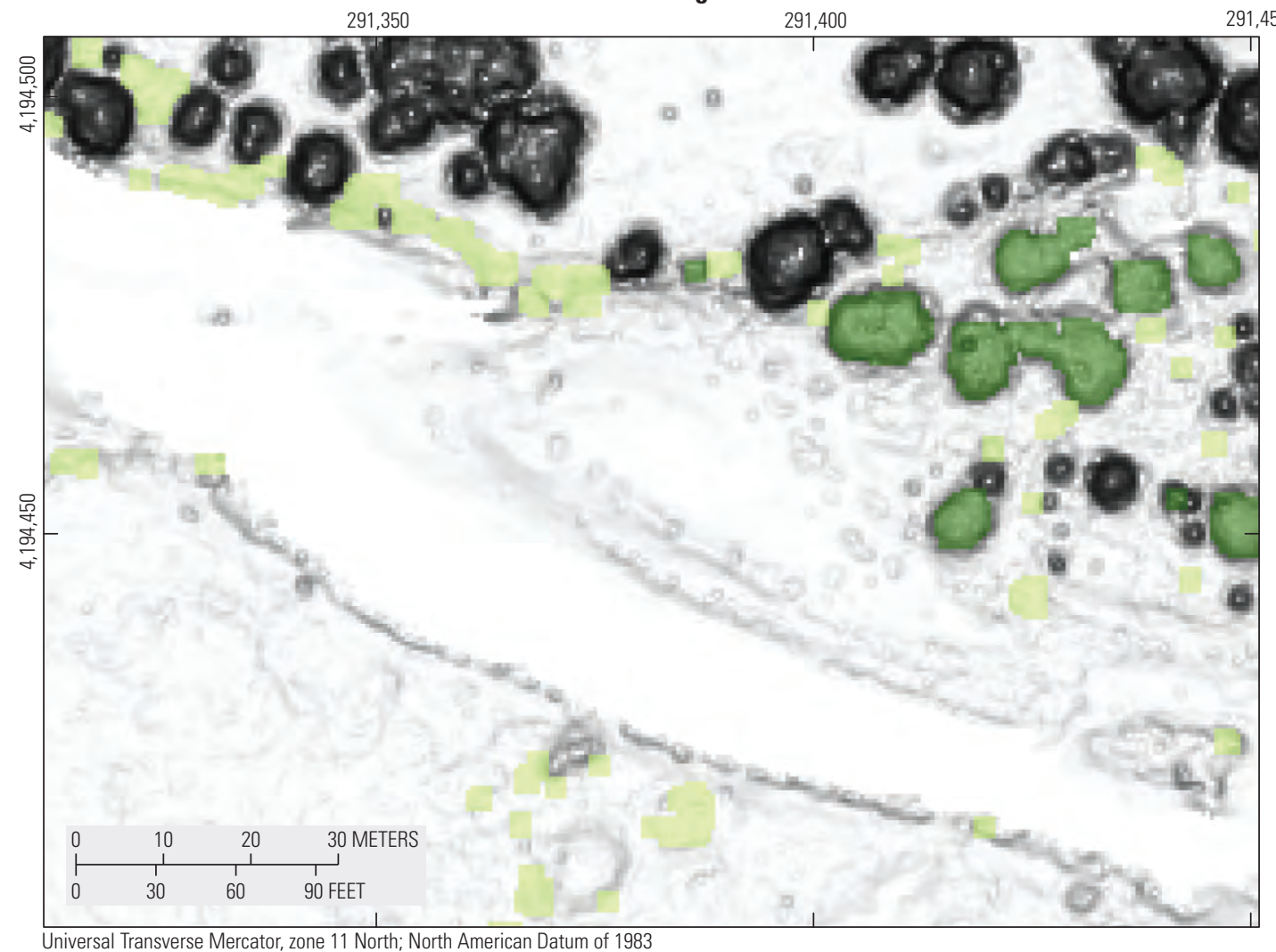

EXPLANATION

Canopy height, in meters

0.25 to 1 -Short vegetation

1 to 4 -Mostly willows

Figure 21. Lidar-derived maps of vegetation at erosion zone 5. Data are from 2018 terrestrial laser scanning (TLS). $A$, shows a semitransparent canopy-height model over full-feature slopeshade. $B$, shows a map of vegetation most likely to be streambank willows and meadow vegetation. 

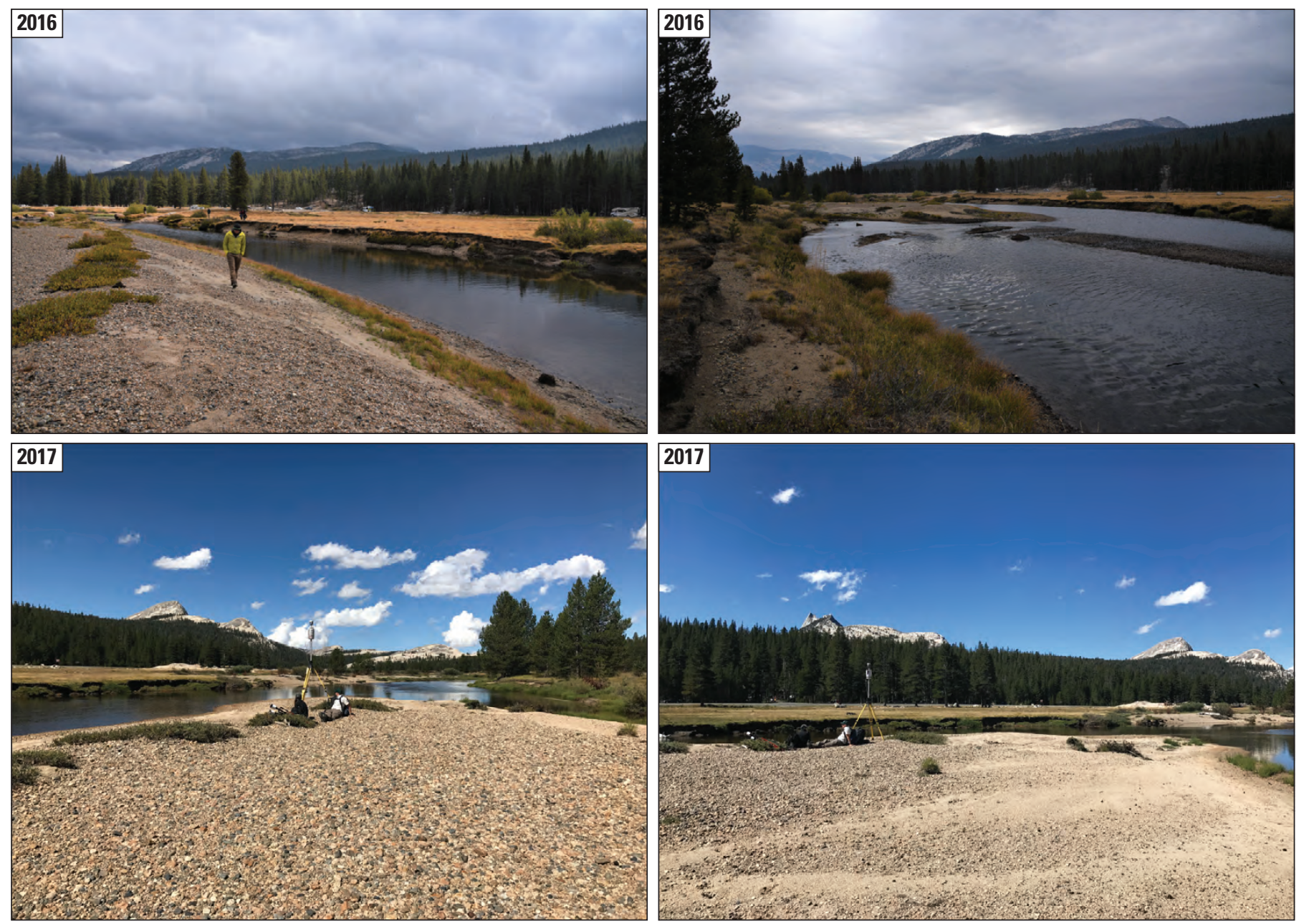

Figure 22. U.S. Geological Survey photographs of erosion zone 5, taken during 2016-2017.

\section{Erosion Zone 6}

Erosion zone 6 is along a gentle bend of the Tuolumne River (fig. 23). The unvegetated point bar across from the active streambank is relatively narrow and creates a narrow channel at its upstream end. The unvegetated bar is connected to a very large vegetated bar that hosts short vegetation and occasional willows (fig. 24). The streambank is eroding grasscovered fluvial sediment and soil. The streambank retreated an average of about $0.53 \mathrm{~m}$ from 2006 to 2016 , about $0.63 \mathrm{~m}$ in 2017, and about $0.13 \mathrm{~m}$ in 2018 (table 8). This amounted to about 112-199 $\mathrm{m}^{3}$ of erosion between 2006 and 2016, as much as about $127 \mathrm{~m}^{3}$ between 2016 and 2017, and 19-27 $\mathrm{m}^{3}$ between 2017 and 2018. Deposition in the zone was negative; the point bar eroded about $69 \mathrm{~m}^{3}$ from 2006 to 2016. From 2016 to 2018, about $82 \mathrm{~m}^{3}$ was deposited on the point bar, and for the entire study period 2006-2018, about $39 \mathrm{~m}^{3}$ was deposited. These values indicate that the narrow point bar in this area did not grow substantially along this relatively narrow reach of channel during the study period. 
A. 2006 ALSM slopeshade

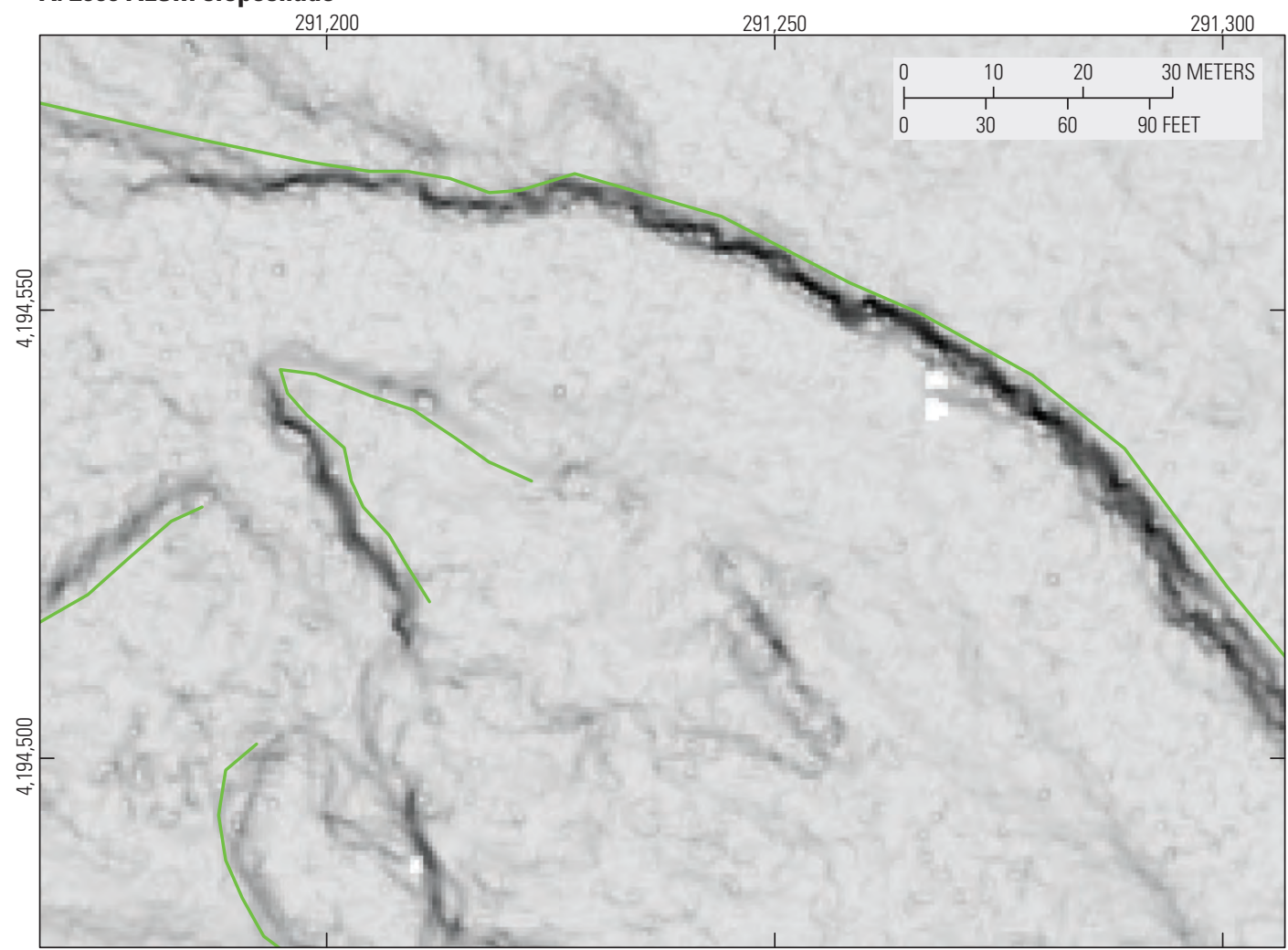

EXPLANATION

2006 streambanks

— Indistinct/stable

- Steep/active

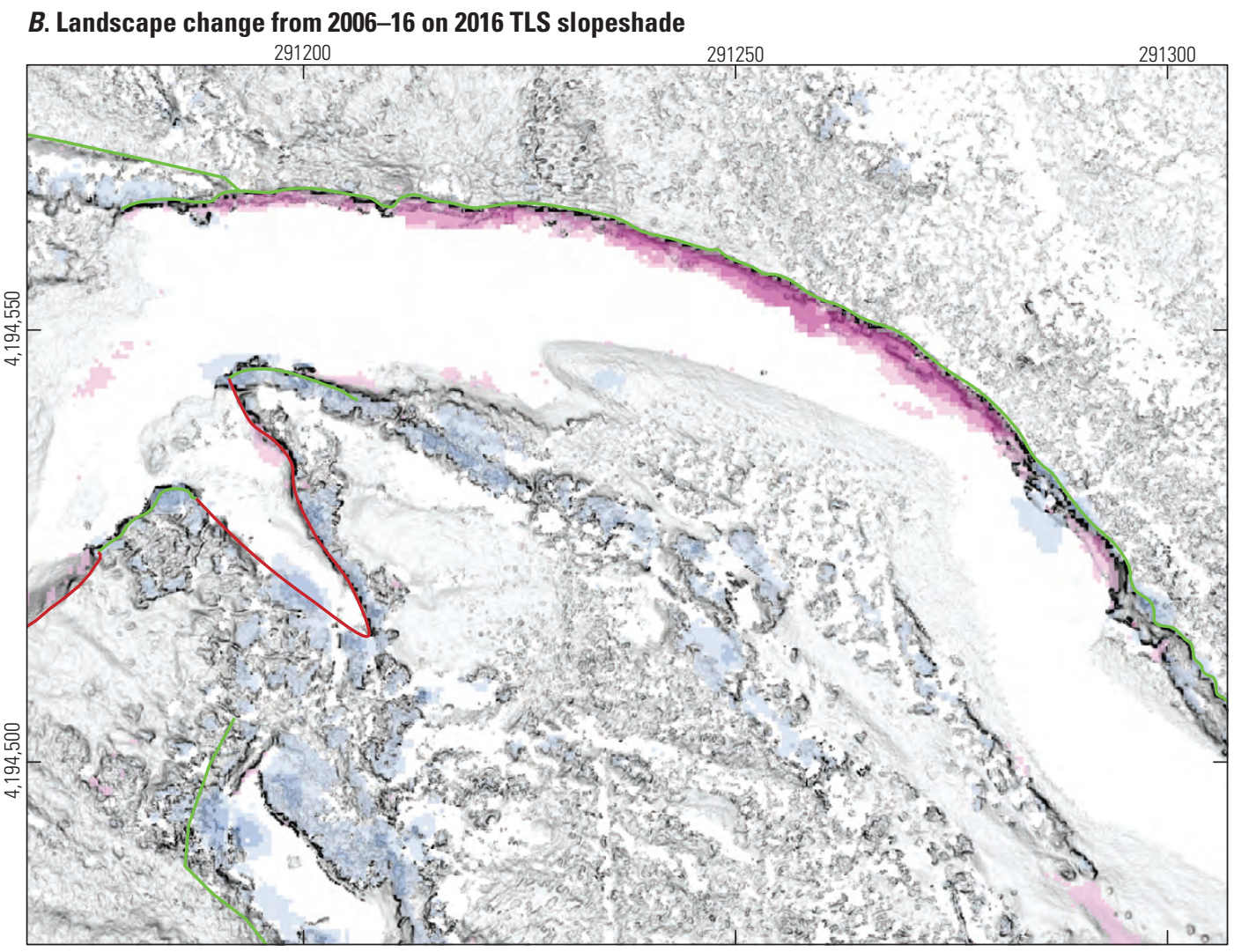

\section{EXPLANATION}

Elevation change, in meters

4 to 2

2 to 1

1 to 0.5

0.5 to 0.2

0.2 to -0.2

-0.2 to -0.5

-0.5 to -1

-1 to -2

-2 to -6

2016 streambanks

__ Indistinct/stable Steep/active

Universal Transverse Mercator, zone 11 North; North American Datum of 1983

Figure 23. Lidar-derived maps showing location and classification of stream banks at erosion zone 6. A, 2006 airborne laser swath mapping (ALSM) bare-earth slopeshade with mapped streambanks. B, 2016 terrestrial laser scanning (TLS) bare-earth slopeshade. C, 2017 TLS bare-earth slopeshade. D, 2018 TLS bare-earth slopeshade. Colors indicate geomorphic change and lines are mapped streambanks. 
C. Landscape change from 2016-17 on 2017 TLS slopeshade

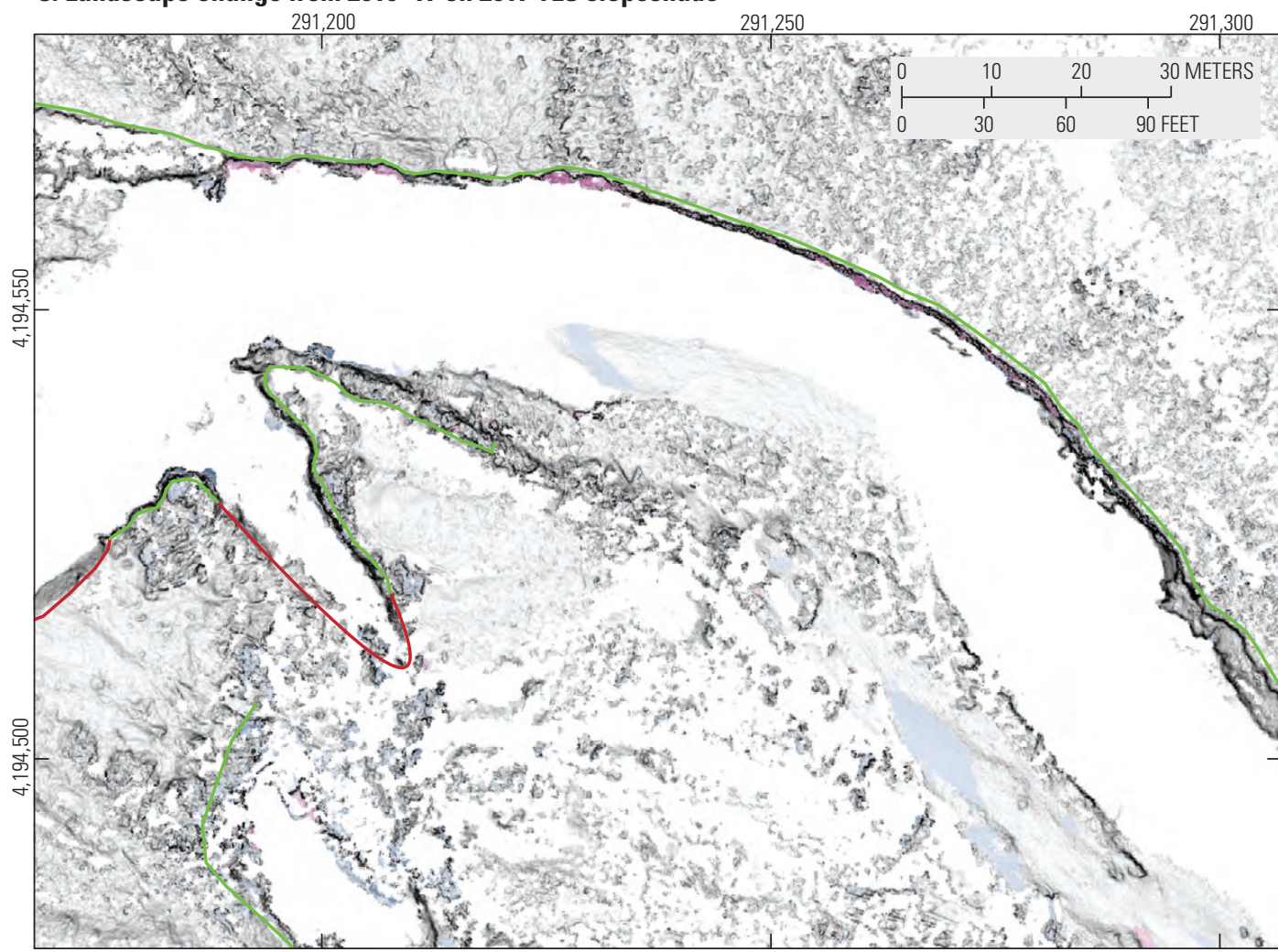

\section{EXPLANATION}

Elevation change, in meters

\begin{tabular}{|l|}
4 to 2 \\
2 to 1 \\
1 to 0.5 \\
0.5 to 0.2 \\
0.2 to -0.2 \\
-0.2 to -0.5 \\
-0.5 to -1 \\
-1 to -2 \\
-2 to -6
\end{tabular}

2017 streambanks

- Indistinct/stable

Steep/active

\section{Landscape change from 2017-18 on 2018 TLS slopeshade}

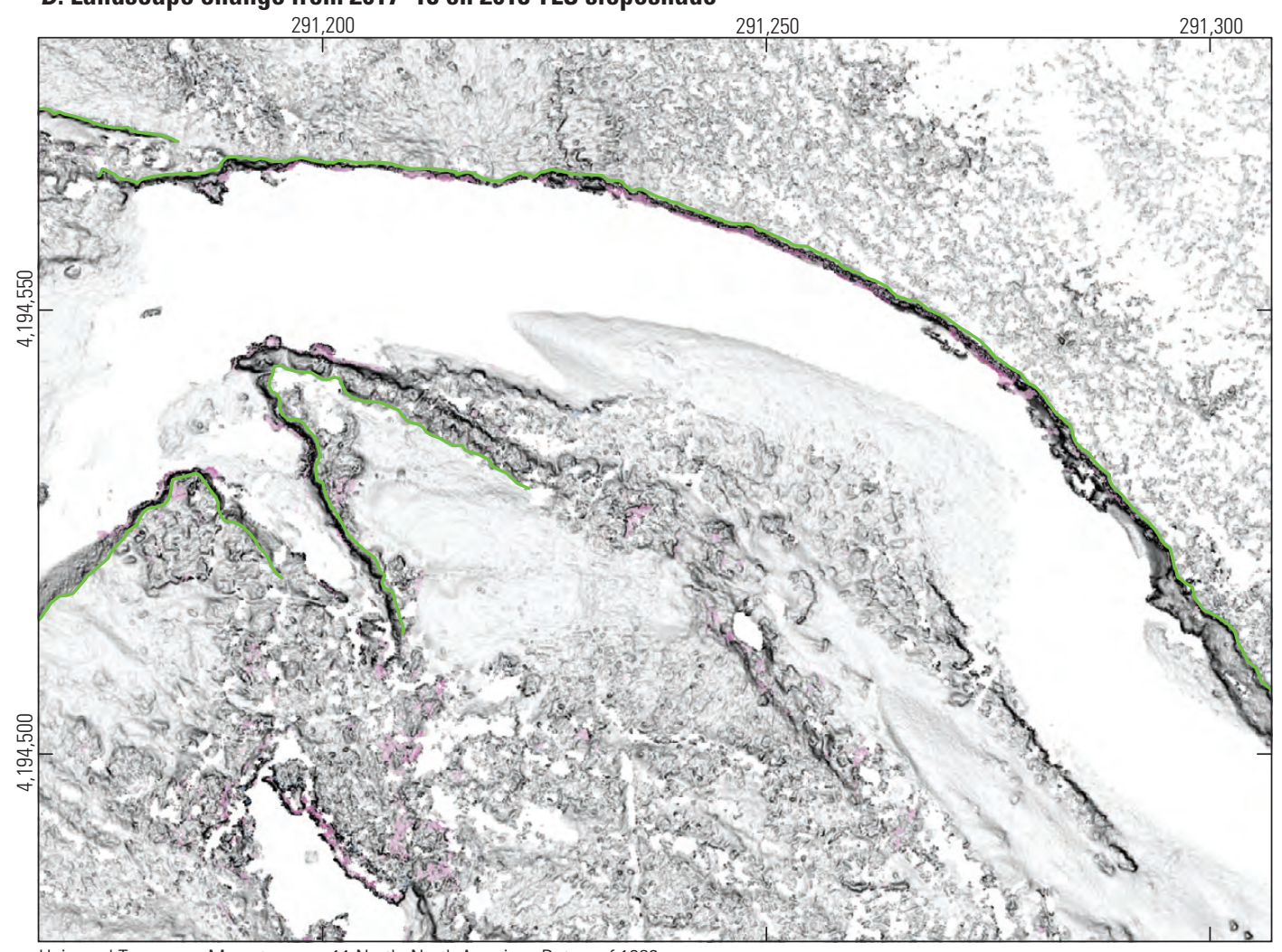

\section{EXPLANATION}

Elevation change, in meters

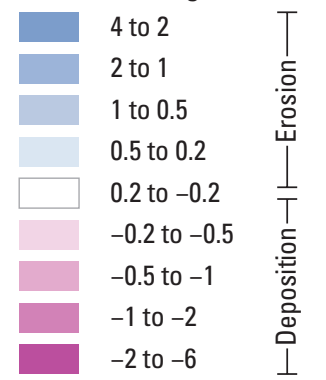

2018 streambanks

_ Indistinct/stable

Steep/active

Universal Transverse Mercator, zone 11 North; North American Datum of 1983

Figure 23.-Continued 
A. Vegetation canopy height from 2018 TLS data

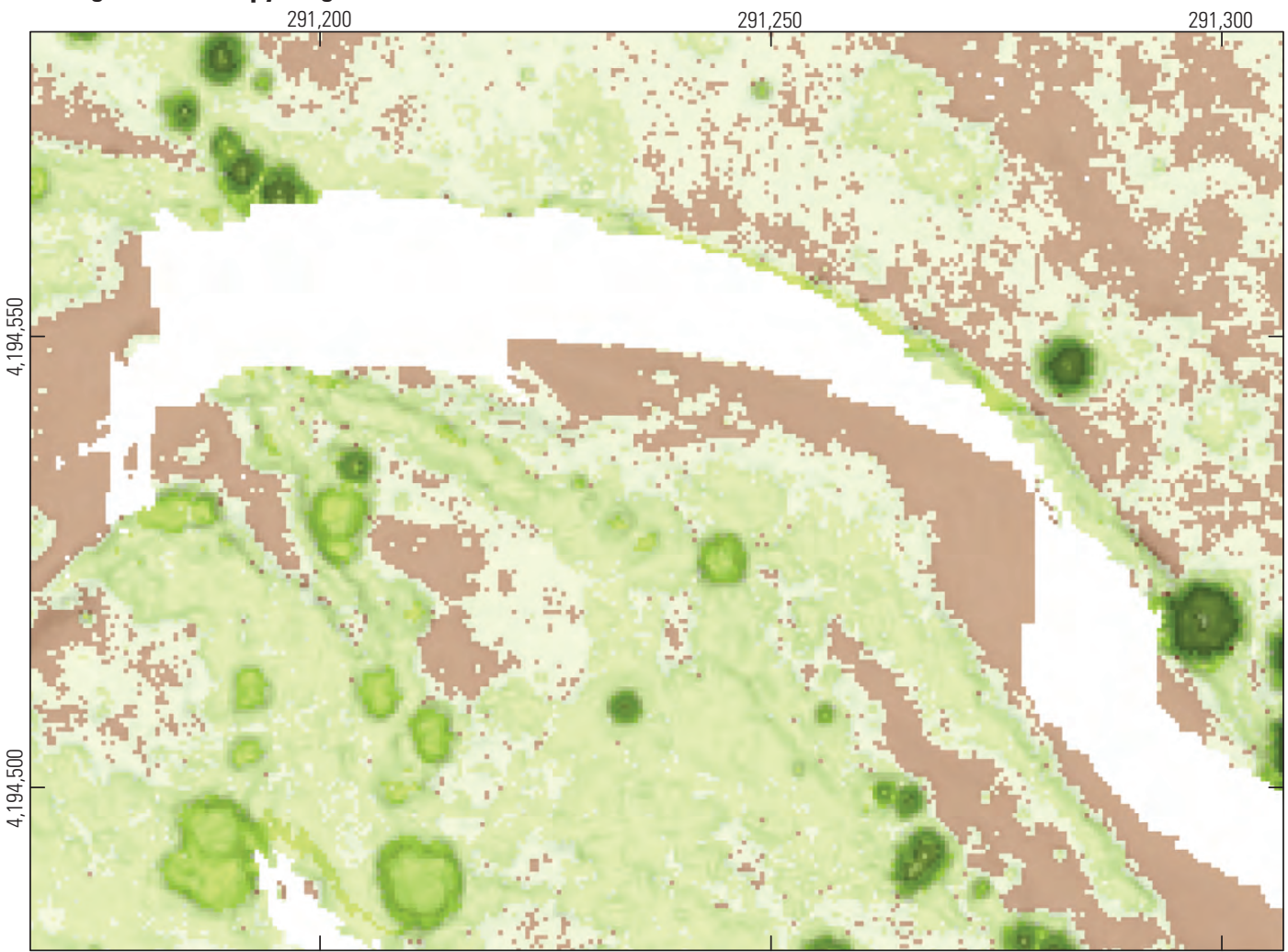

\section{EXPLANATION}

Canopy height, in meters $<0.1$

0.1 to 0.25

0.25 to 1

1 to 2

2 to 4

4 to 10

10 to 20

20 to 30

30 to 50

\section{B. Presence of streambank willows and other meadow vegetation from 2018 TLS data}

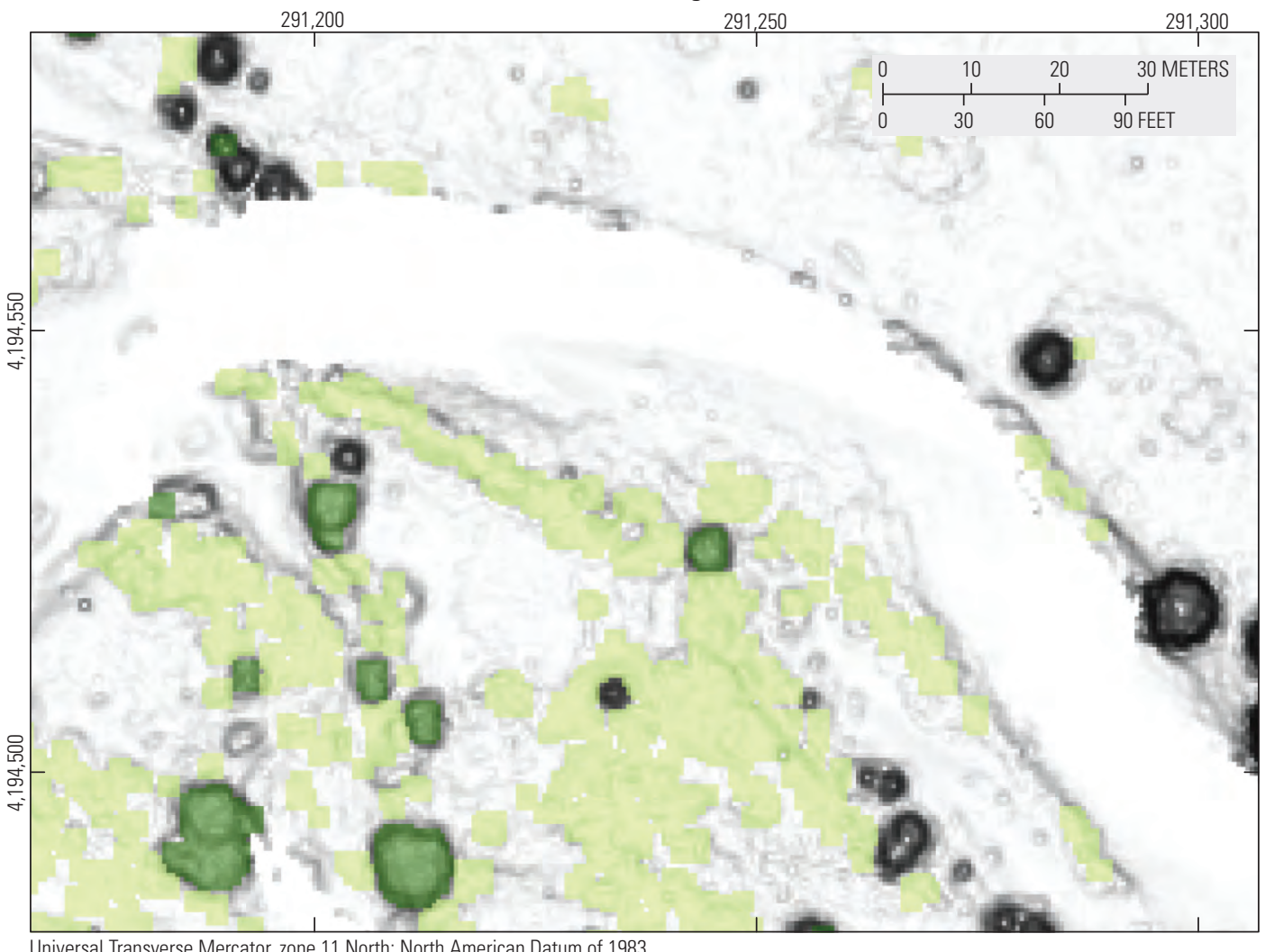

EXPLANATION

Canopy height, in meters

0.25 to 1 -Short vegetation

1 to 4 -Mostly willows

Universal Transverse Mercator, zone 11 North; North American Datum of 1983

Figure 24. Lidar-derived maps of vegetation at erosion zone 6. Data are from 2018 terrestrial laser scanning (TLS). A, shows a semitransparent canopy-height model over full-feature slopeshade. $B$, shows a map of vegetation most likely to be streambank willows and meadow vegetation. 

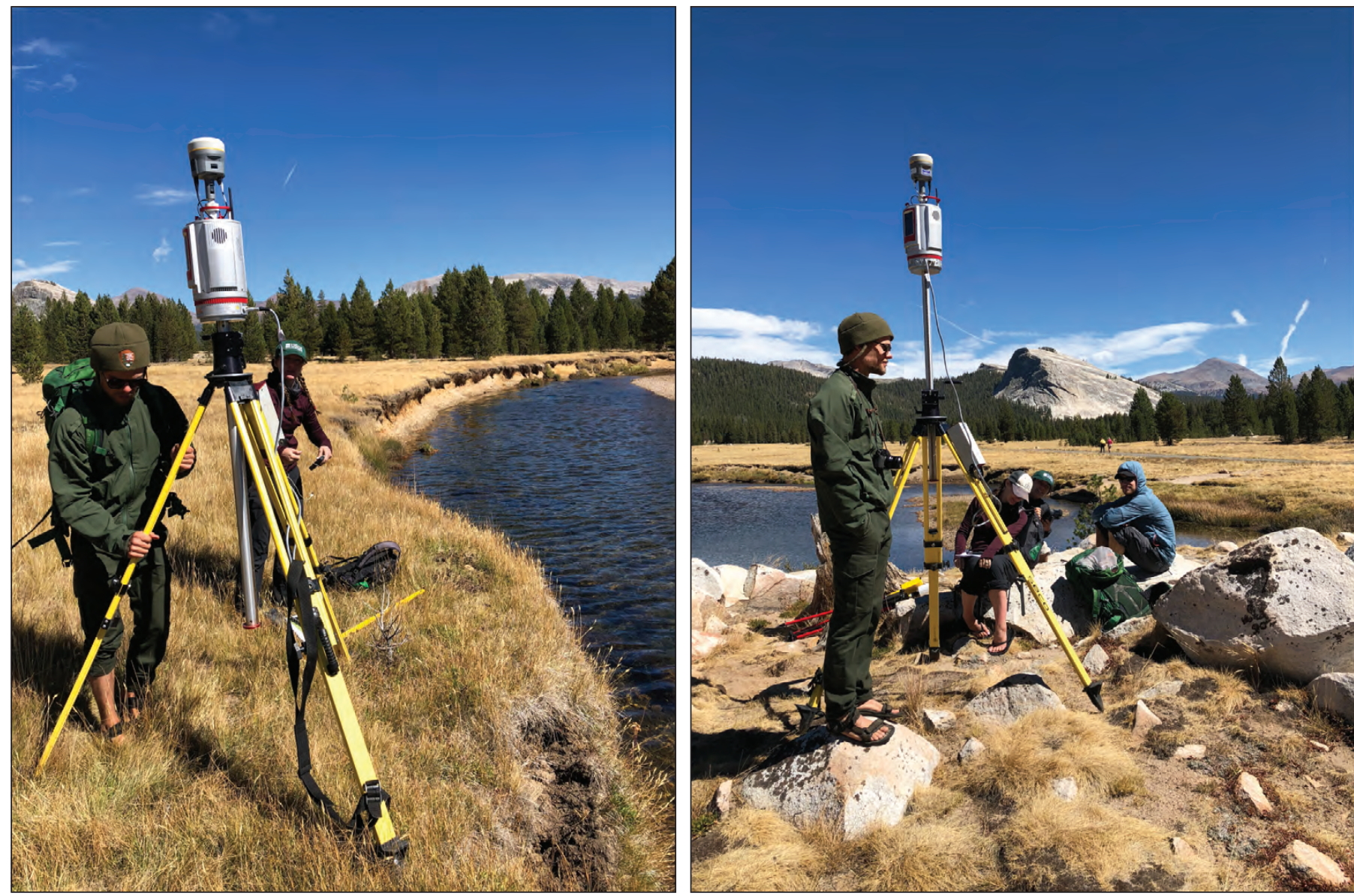

Figure 25. U.S. Geological Survey photographs of erosion zone 6, taken in 2018.

Table 8. Estimates of erosion and deposition at erosion zone 6 along Tuolumne River.

[---, no data; DEM, digital elevation model; DoD, DEMs of difference; $\mathrm{m}$, meter; $\mathrm{m}^{2}$, square meter; $\mathrm{m}^{3}$, cubic meter]

\begin{tabular}{|c|c|c|c|c|c|c|c|c|}
\hline \multirow[b]{2}{*}{$\begin{array}{c}\text { Erosion } \\
\text { zone }\end{array}$} & \multirow[b]{2}{*}{$\begin{array}{c}\text { Surveyed } \\
\text { interval }\end{array}$} & \multirow[b]{2}{*}{$\begin{array}{c}\text { Streambank } \\
\text { or bar }\end{array}$} & \multicolumn{2}{|c|}{ From DEM change mapping } & \multicolumn{4}{|c|}{ From streambank mapping } \\
\hline & & & $\begin{array}{l}\text { Area of data } \\
\text { in zone }\left(\mathrm{m}^{2}\right)\end{array}$ & $\begin{array}{l}\text { Volume change } \\
\text { from } \operatorname{DoD}\left(\mathrm{m}^{3}\right)\end{array}$ & $\begin{array}{c}\text { Active } \\
\text { streambank } \\
\text { length (m) }\end{array}$ & $\begin{array}{c}\text { Bank } \\
\text { height }(\mathrm{m})\end{array}$ & $\begin{array}{c}\text { Average bank } \\
\text { retreat }(\mathrm{m})\end{array}$ & $\begin{array}{c}\text { Volume change } \\
\text { from streambank } \\
\text { mapping }\left(\mathrm{m}^{3}\right)\end{array}$ \\
\hline 6 & 2006-2016 & Bank & 892 & a-198.7 & 121 & 1.40 & 0.53 & -112.2 \\
\hline 6 & 2006-2017 & Bar & 948 & ${ }^{\mathrm{a}} 61.6$ & --- & --- & --- & --- \\
\hline 6 & 2006-2018 & Bank & 778 & $\mathrm{a}-126.5$ & --- & --- & --- & --- \\
\hline 6 & 2016-2017 & Bar & 663 & b46.5 & --- & --- & --- & --- \\
\hline 6 & 2016-2017 & Bank & 425 & $\mathrm{~b}-6.9$ & 95 & 1.40 & 0.63 & -126.8 \\
\hline 6 & $2017-2018$ & Bar & 688 & b2.6 & --- & --- & --- & --- \\
\hline 6 & $2017-2018$ & Bank & 395 & b-19.3 & 120 & 1.40 & 0.13 & -27.3 \\
\hline
\end{tabular}

${ }^{a}$ Calculated from 50-cm-resolution digital elevation models at 4-cm level of detection.

${ }^{\mathrm{b}}$ Calculated from $10-\mathrm{cm}$-resolution digital elevation models at 2-cm level of detection. 


\section{Erosion Zone 7}

Erosion zone 7 is a relatively long (greater than $250 \mathrm{~m}$ ) reach of eroding streambank along a gentle northward bend in the Tuolumne River. In this area, there is a small channel bar and two connected point bars (fig. 26). The streambank is eroding a grass covered surface underlain by soil and fluvial sediment (figs. 27 and 28). From 2006 to 2016 the streambank retreated an average of about $0.19 \mathrm{~m}$, from 2016 to 2017 it retreated about $0.71 \mathrm{~m}$, and from 2017 to 2018 it retreated about $0.16 \mathrm{~m}$ (table 9). Erosion from 2006 to 2016 as calculated from the DoD was about $205 \mathrm{~m}^{3}$, this exceeded that estimated from streambank retreat of about $65 \mathrm{~m}^{3}$, which is an indication that erosion removed a substantial amount of material previously stored below the streambank as well as material eroded by streambank retreat. About $134 \mathrm{~m}^{3}$ of sediment was removed from the bars from 2006 to 2016. From 2016 to 2018 , bar deposition was about $142 \mathrm{~m}^{3}$, and streambank erosion was between about 37 and $65 \mathrm{~m}^{3}$. For the entire study period 2006-2018, streambank erosion of between 258 and $262 \mathrm{~m}^{3}$ exceeded point and channel bar deposition of $72 \mathrm{~m}^{3}$.

Table 9. Estimates of erosion and deposition at erosion zone 7 along Tuolumne River.

[---, no data; DEM, digital elevation model; DoD, DEMs of difference; $\mathrm{m}$, meter; $\mathrm{m}^{2}$, square meter; $\mathrm{m}^{3}$, cubic meter]

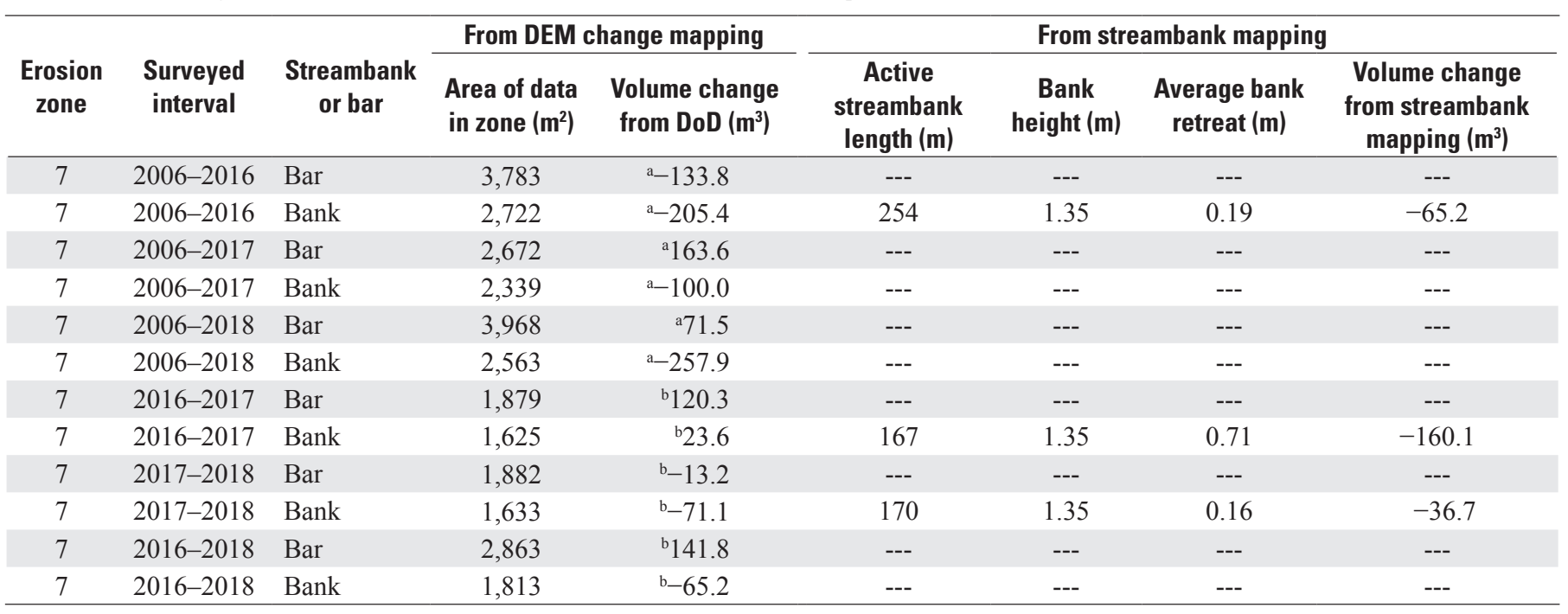

${ }^{a}$ Calculated from 50-cm-resolution digital elevation models at 4-cm level of detection.

${ }^{\mathrm{b}}$ Calculated from 10-cm-resolution digital elevation models at 2-cm level of detection. 
A. 2006 ALSM slopeshade

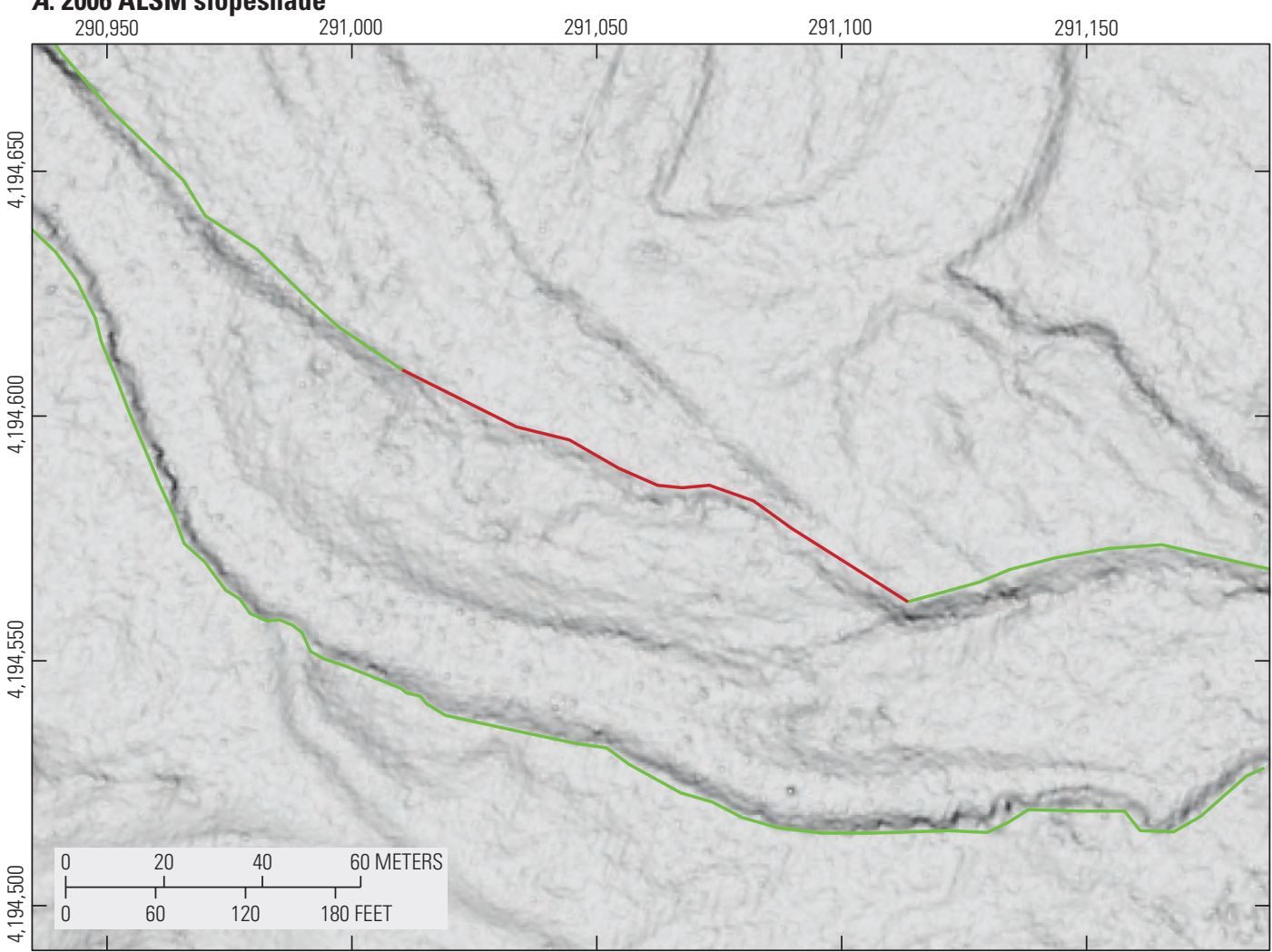

EXPLANATION

2006 streambanks

—_ Indistinct/stable

— Steep/active

B. Landscape change from 2006-16 on 2016 TLS slopeshade

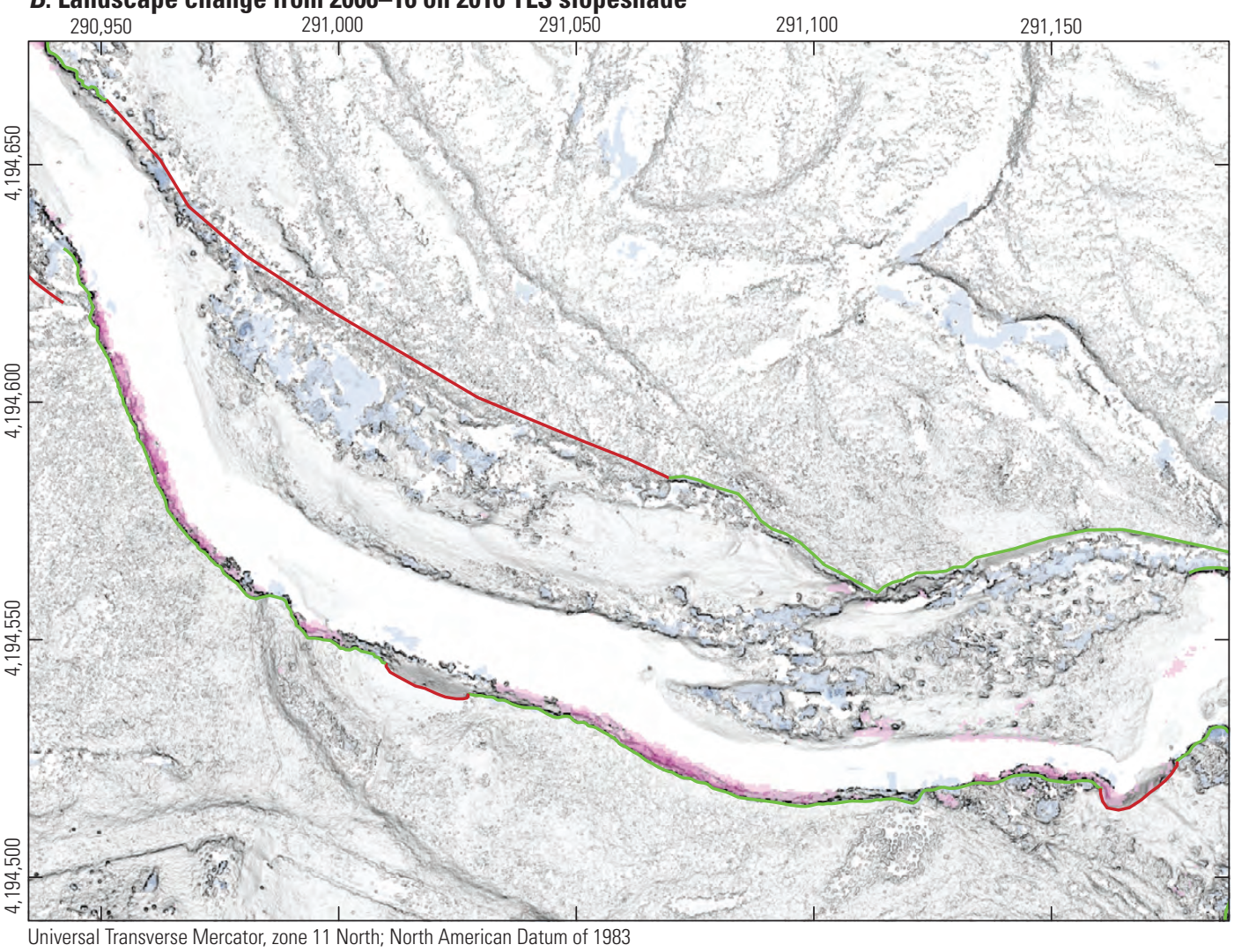

EXPLANATION

Elevation change, in meters

4 to 2

2 to 1

1 to 0.5

0.5 to 0.2

0.2 to -0.2

-0.2 to -0.5

-0.5 to -1

-1 to -2

-2 to -6

2016 streambanks

_ Indistinct/stable Steep/active

Figure 26. Lidar-derived maps showing location and classification of stream banks at erosion zone 7. A, 2006 airborne laser swath mapping (ALSM) bare-earth slopeshade with mapped streambanks. $B, 2016$ terrestrial laser scanning (TLS) bare-earth slopeshade. C, 2017 TLS bare-earth slopeshade. D, 2018 TLS bare-earth slopeshade. Colors indicate geomorphic change and lines are mapped streambanks. 
C. Landscape change from 2016-17 on 2017 TLS slopeshade

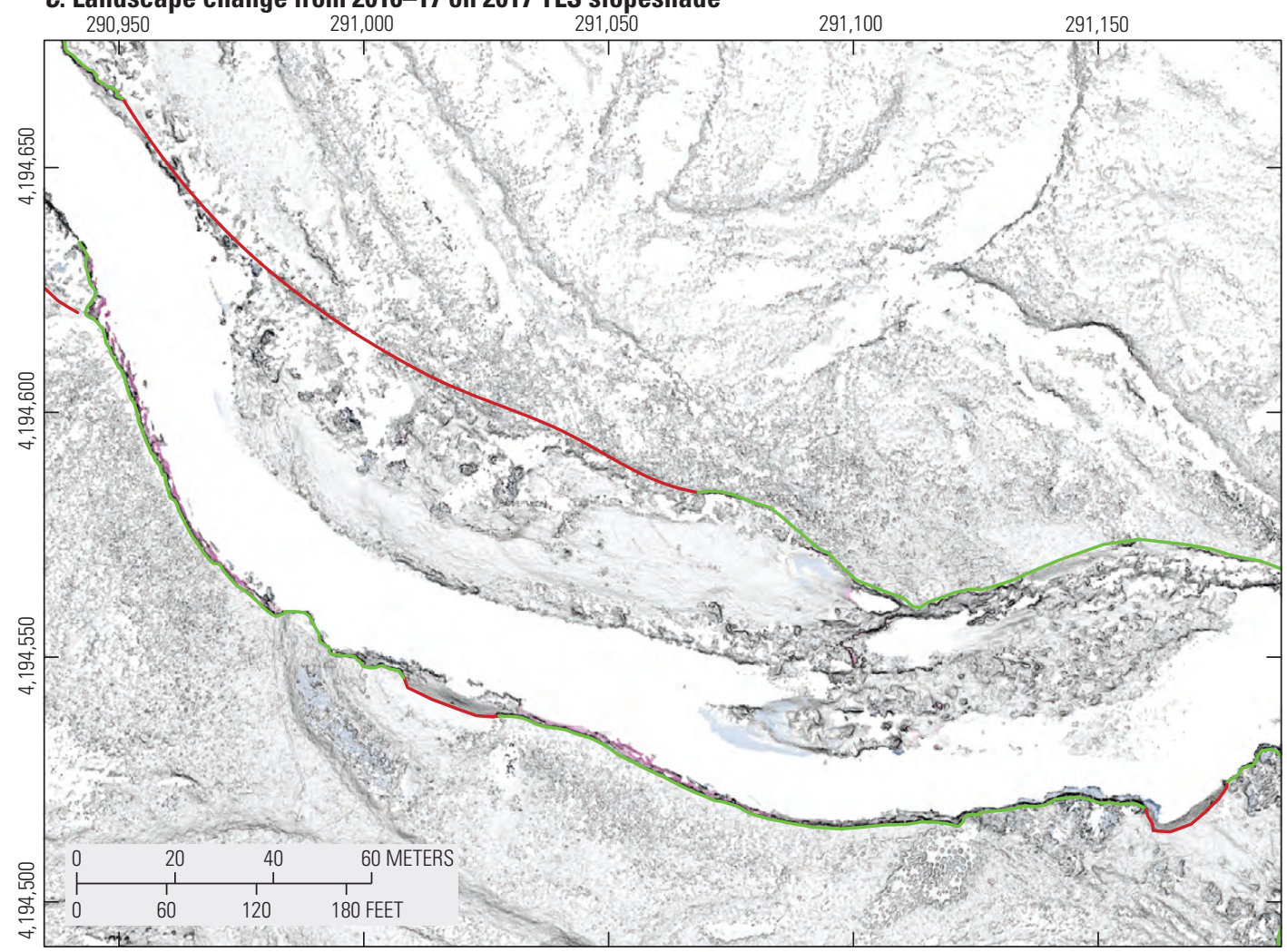

EXPLANATION

Elevation change, in meters

\begin{tabular}{|l|}
\hline 4 to 2 \\
2 to 1 \\
1 to 0.5 \\
0.5 to 0.2 \\
0.2 to -0.2 \\
-0.2 to -0.5 \\
-0.5 to -1 \\
-1 to -2 \\
-2 to -6
\end{tabular}

2017 streambanks

Indistinct/stable Steep/active

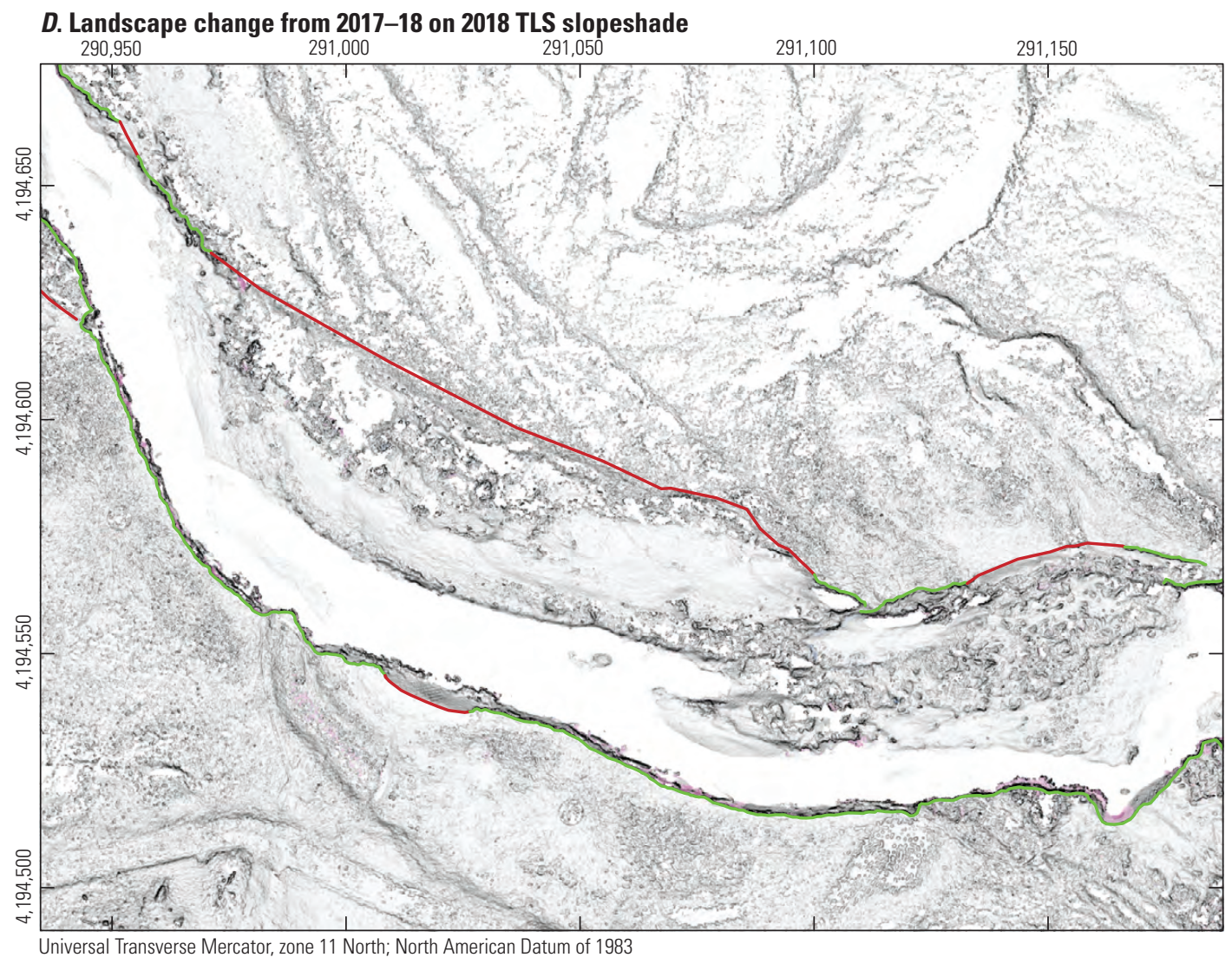

EXPLANATION

Elevation change, in meters

4 to 2
2 to 1
1 to 0.5
0.5 to 0.2
0.2 to -0.2
-0.2 to -0.5
-0.5 to -1
-1 to -2
-2 to -6

2018 streambanks

- Indistinct/stable Steep/active

Figure 26.-Continued 
A. Vegetation canopy height from 2018 TLS data

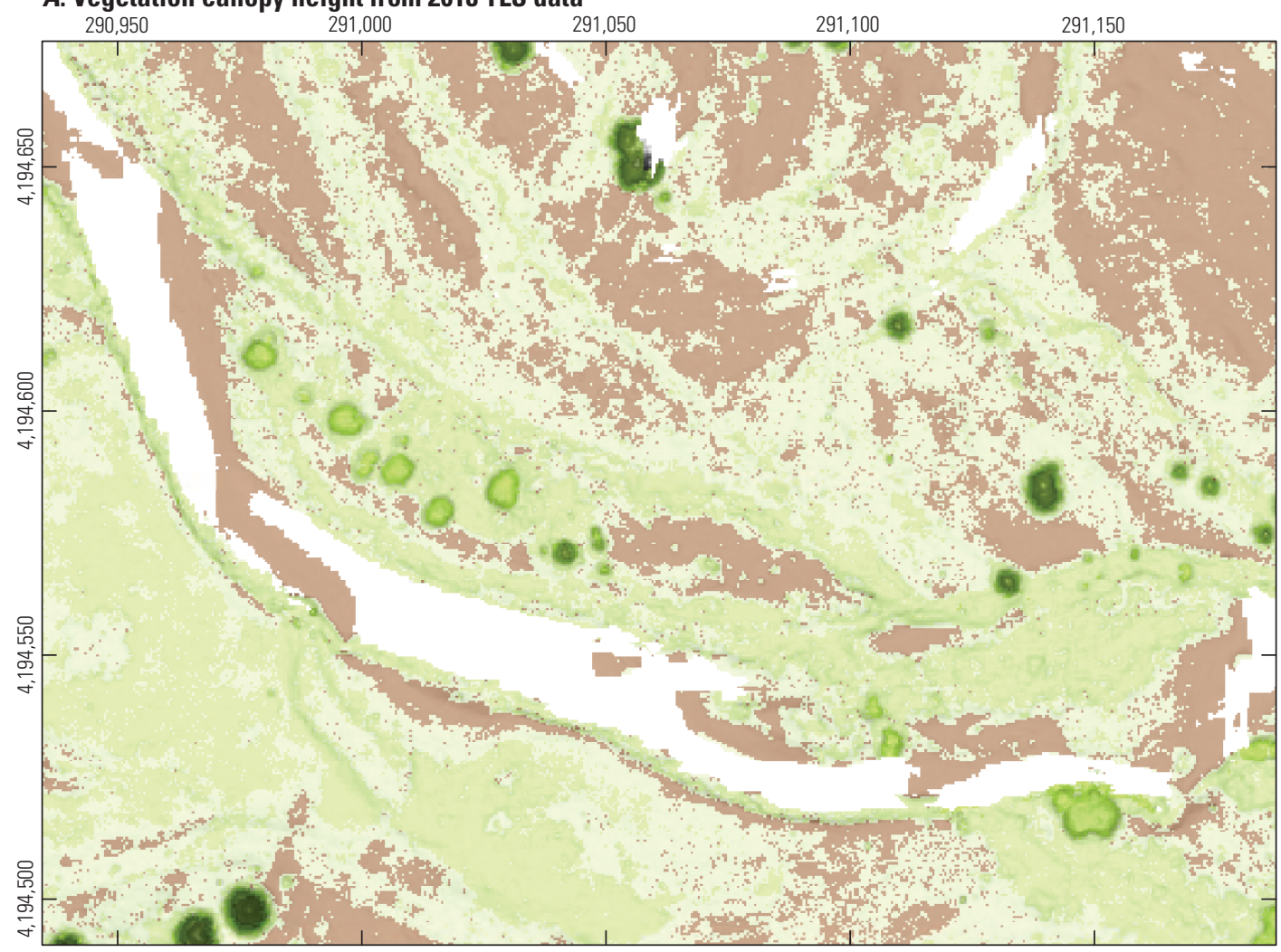

\section{EXPLANATION}

Canopy height, in meters

$<0.1$

0.1 to 0.25

0.25 to 1

1 to 2

2 to 4

4 to 10

10 to 20

20 to 30

30 to 50

$B$. Presence of streambank willows and other meadow vegetation from 2018 TLS data

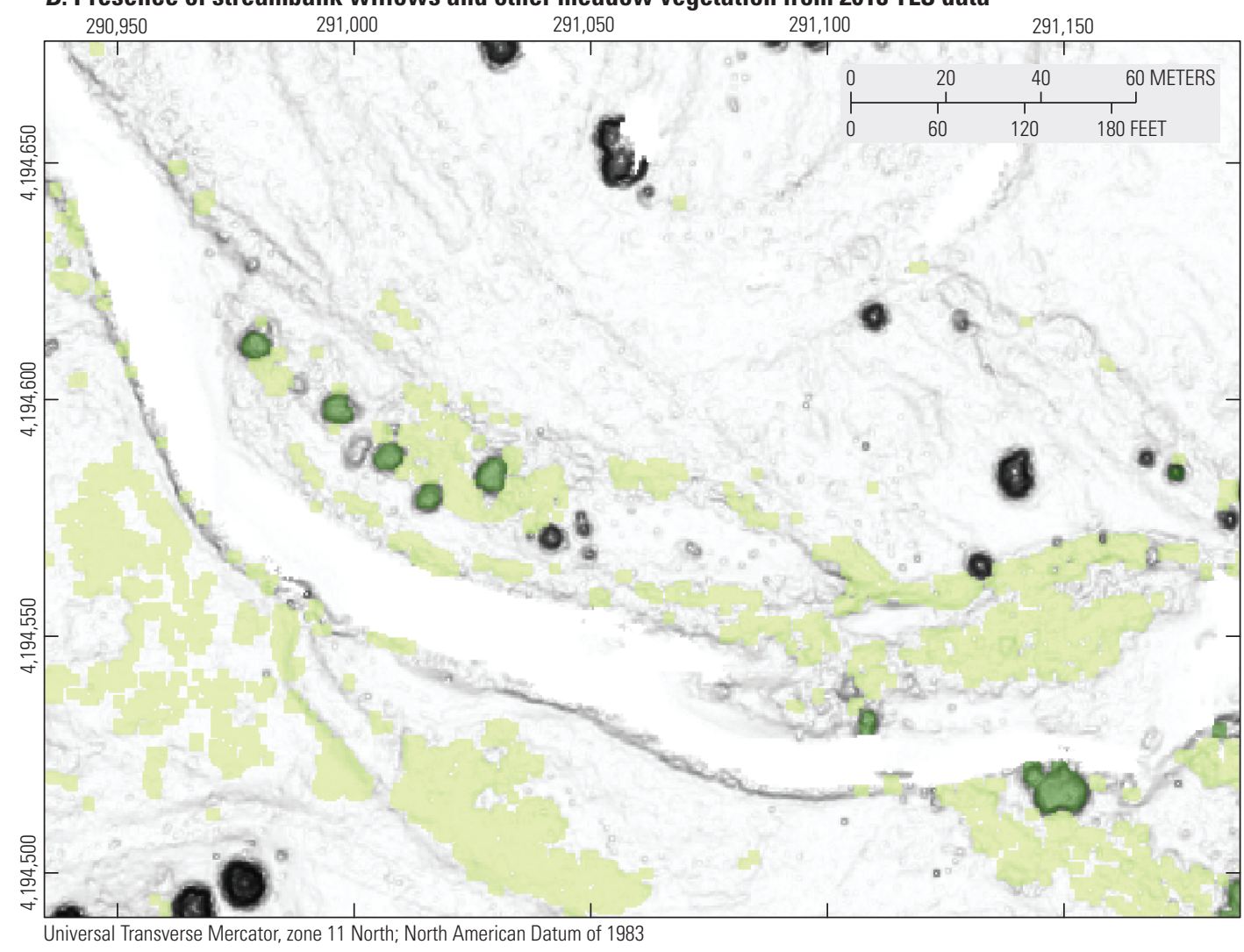

EXPLANATION

Canopy height, in meters

0.25 to 1 -Short vegetation

1 to 4 -Mostly willows

Figure 27. Lidar-derived maps of vegetation at erosion zone 7. Data are from 2018 terrestrial laser scanning (TLS). $A$, shows a semitransparent canopy-height model over full-feature slopeshade. $B$, shows a map of vegetation most likely to be streambank willows and meadow vegetation. 

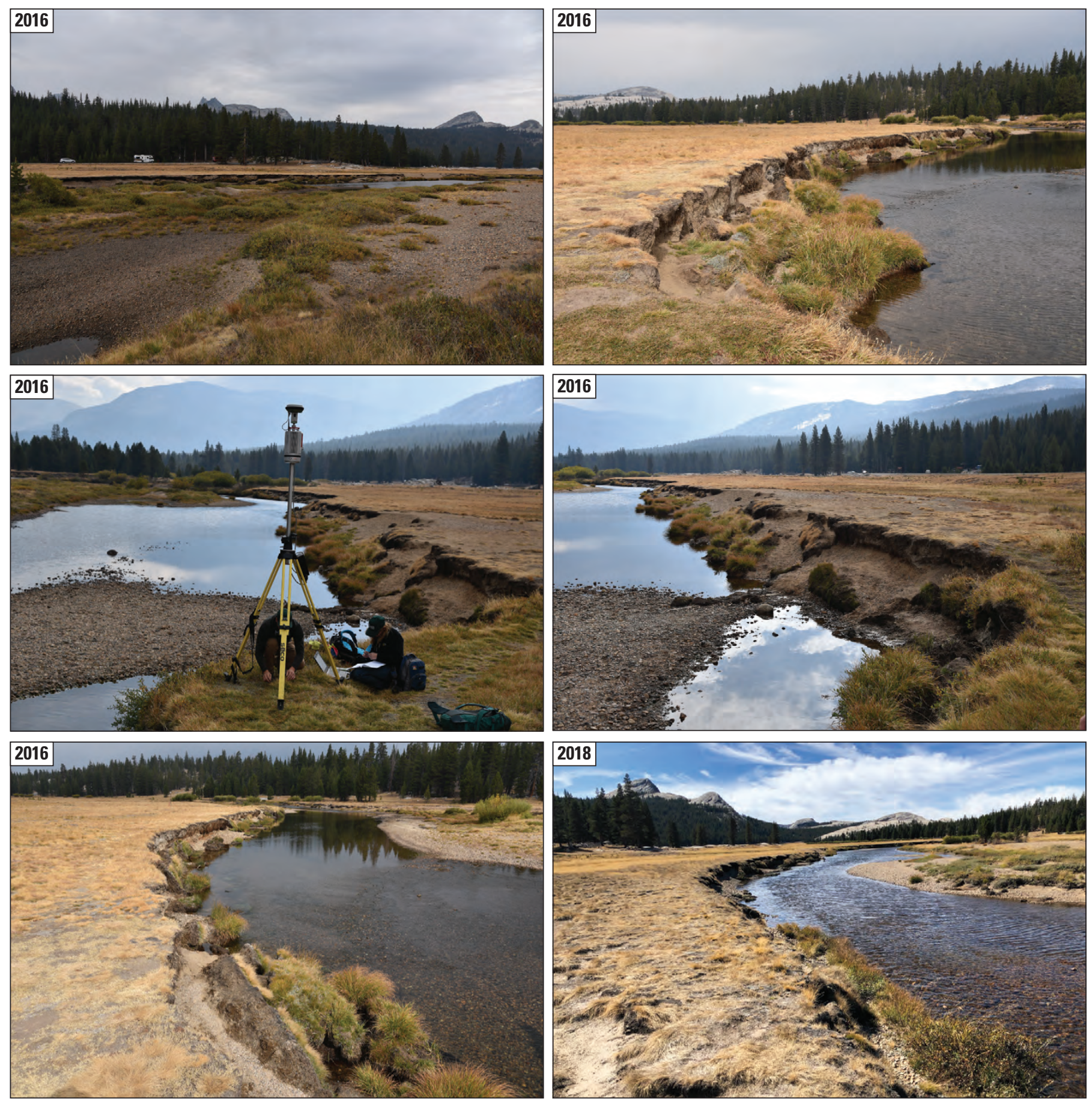

Figure 28. U.S. Geological Survey photographs of erosion zone 7, taken during 2016-2018. 


\section{Erosion Zone 8}

Erosion zone 8 has a $40 \mathrm{~m}$ long retreating streambank on the northeast side of a straight section of the Tuolumne River. A straight and narrow depositional bar is opposite of the eroding streambank (fig. 29). The streambank is eroding grass- and short-vegetation-covered soil and fluvial sediment (fig. 30), which is somewhat less well-defined than others, and has some sediment deposition along its length (fig. 31). The eroding length of streambank retreated an average of $0.19 \mathrm{~m}$ from 2006 to 2016, $0.60 \mathrm{~m}$ during 2017, and $0.12 \mathrm{~m}$ during 2018 (table 10). From 2006 to 2016, both the streambank and opposite bar eroded. The bar lost about $64 \mathrm{~m}^{3}$ of sediment and the streambank lost between about 30 and $65 \mathrm{~m}^{3}$ of sediment. From 2016 to 2018, the streambank eroded just about 5 to $14 \mathrm{~m}^{3}$ of sediment and the bar gained about $43 \mathrm{~m}^{3}$ of sediment. Over the full study period 2006 to 2018 , the bar gained about $18 \mathrm{~m}^{3}$ of sediment while the streambank was eroded by between 29 and $85 \mathrm{~m}^{3}$ of sediment. These amounts are relatively modest compared to other erosion zones.

Table 10. Estimates of erosion and deposition at erosion zone 8 along Tuolumne River.

[---, no data; DEM, digital elevation model; DoD, DEMs of difference; $\mathrm{m}$, meter; $\mathrm{m}^{2}$, square meter; $\mathrm{m}^{3}$, cubic meter]

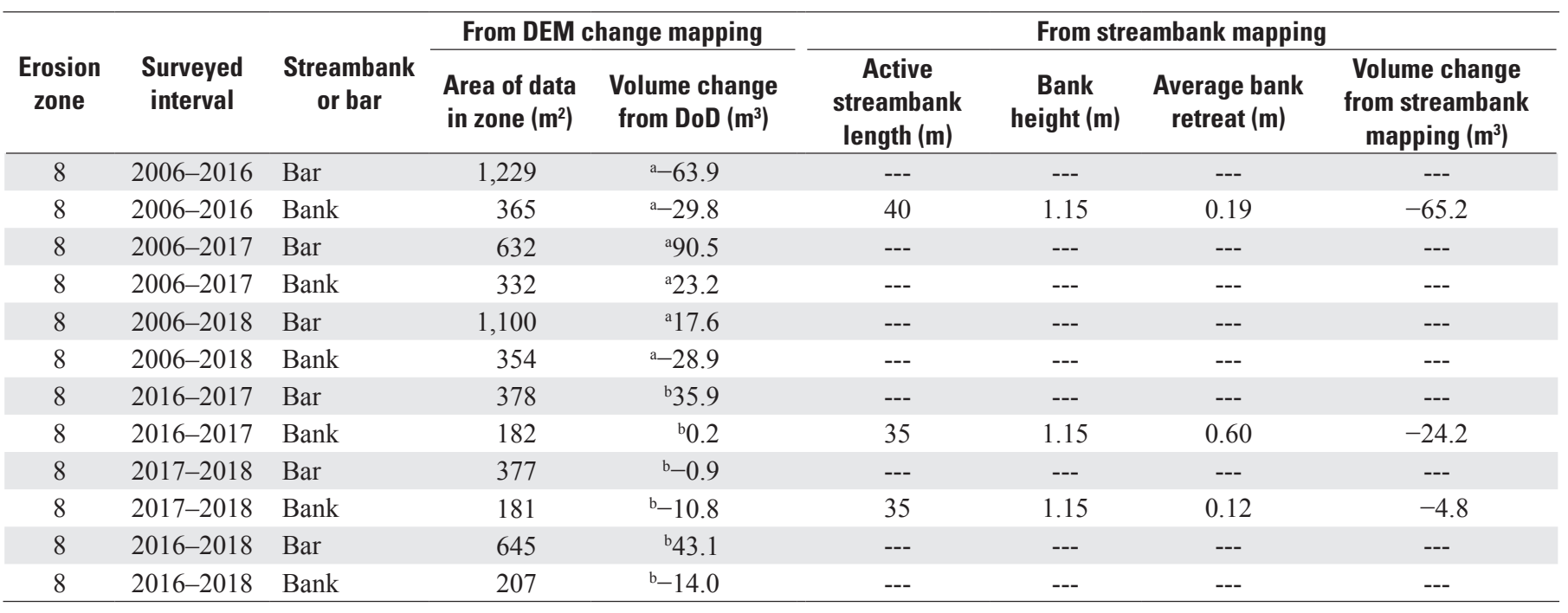

${ }^{a}$ Calculated from 50-cm-resolution digital elevation models at 4-cm level of detection.

${ }^{\mathrm{b}}$ Calculated from $10-\mathrm{cm}$-resolution digital elevation models at 2-cm level of detection. 


\section{A. 2006 ALSM slopeshade}

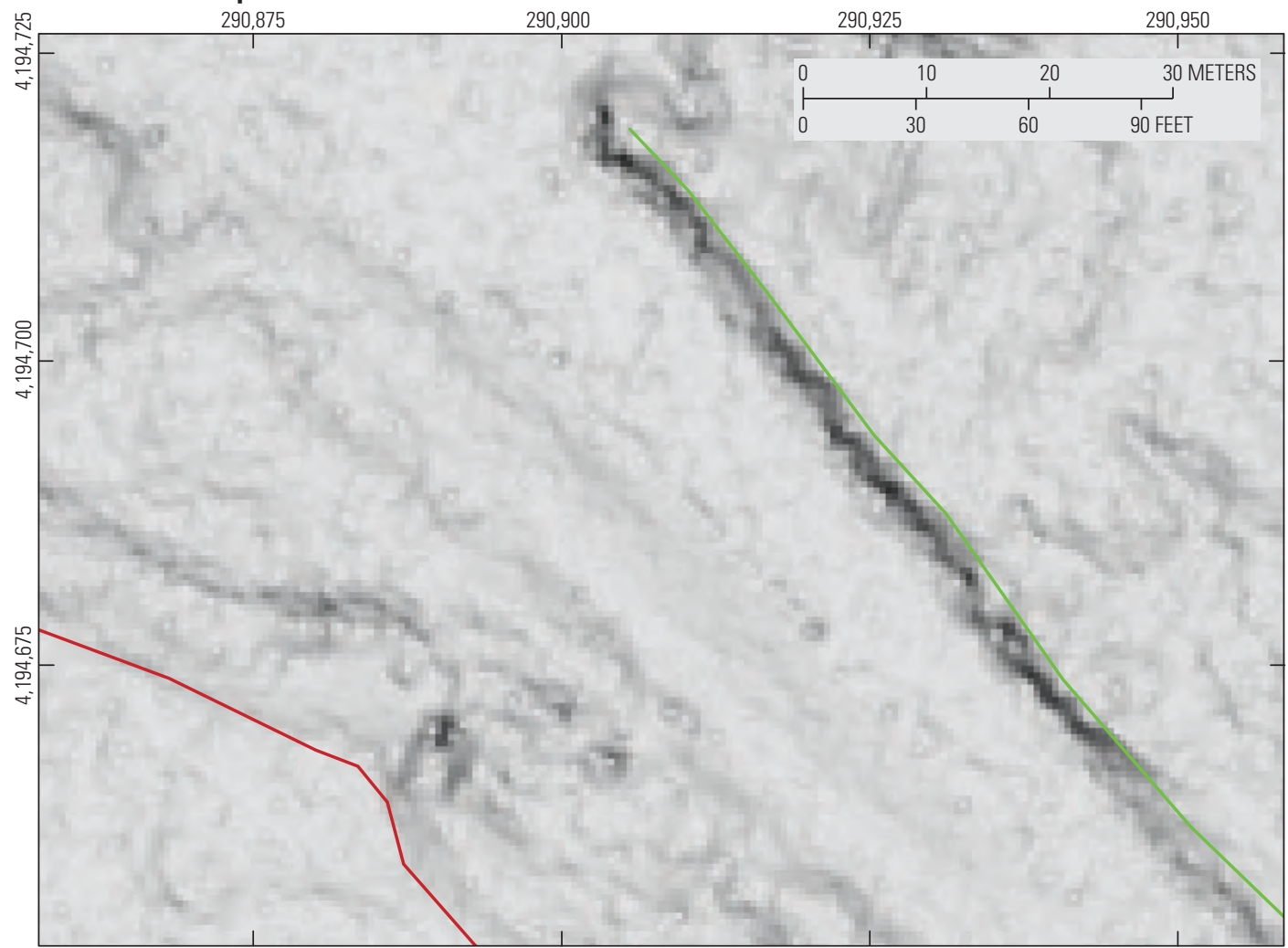

\section{EXPLANATION}

2006 streambanks

_ Indistinct/stable

- Steep/active

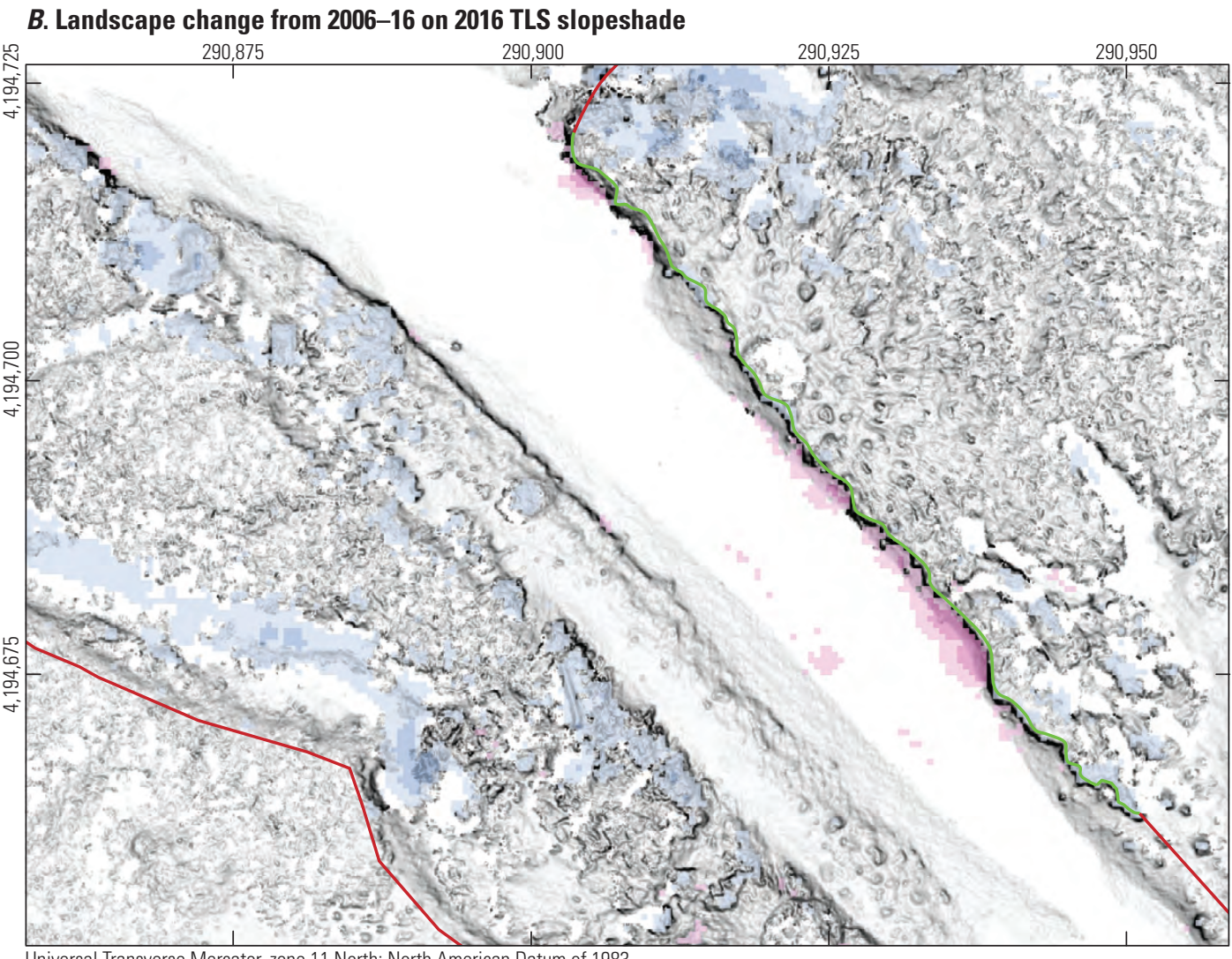

\section{EXPLANATION}

Elevation change, in meters

\begin{tabular}{|l|}
\hline 4 to 2 \\
2 to 1 \\
1 to 0.5 \\
0.5 to 0.2 \\
0.2 to -0.2 \\
-0.2 to -0.5 \\
-0.5 to -1 \\
-1 to -2 \\
-2 to -6
\end{tabular}

2016 streambanks

- Indistinct/stable Steep/active

Figure 29. Lidar-derived maps showing location and classification of stream banks at erosion zone 8. $A, 2006$ airborne laser swath mapping (ALSM) bare-earth slopeshade with mapped streambanks. B, 2016 terrestrial laser scanning (TLS) bare-earth slopeshade. C, 2017 TLS bare-earth slopeshade. D, 2018 TLS bare-earth slopeshade. Colors indicate geomorphic change and lines are mapped streambanks. 
C. Landscape change from 2016-17 on 2017 TLS slopeshade

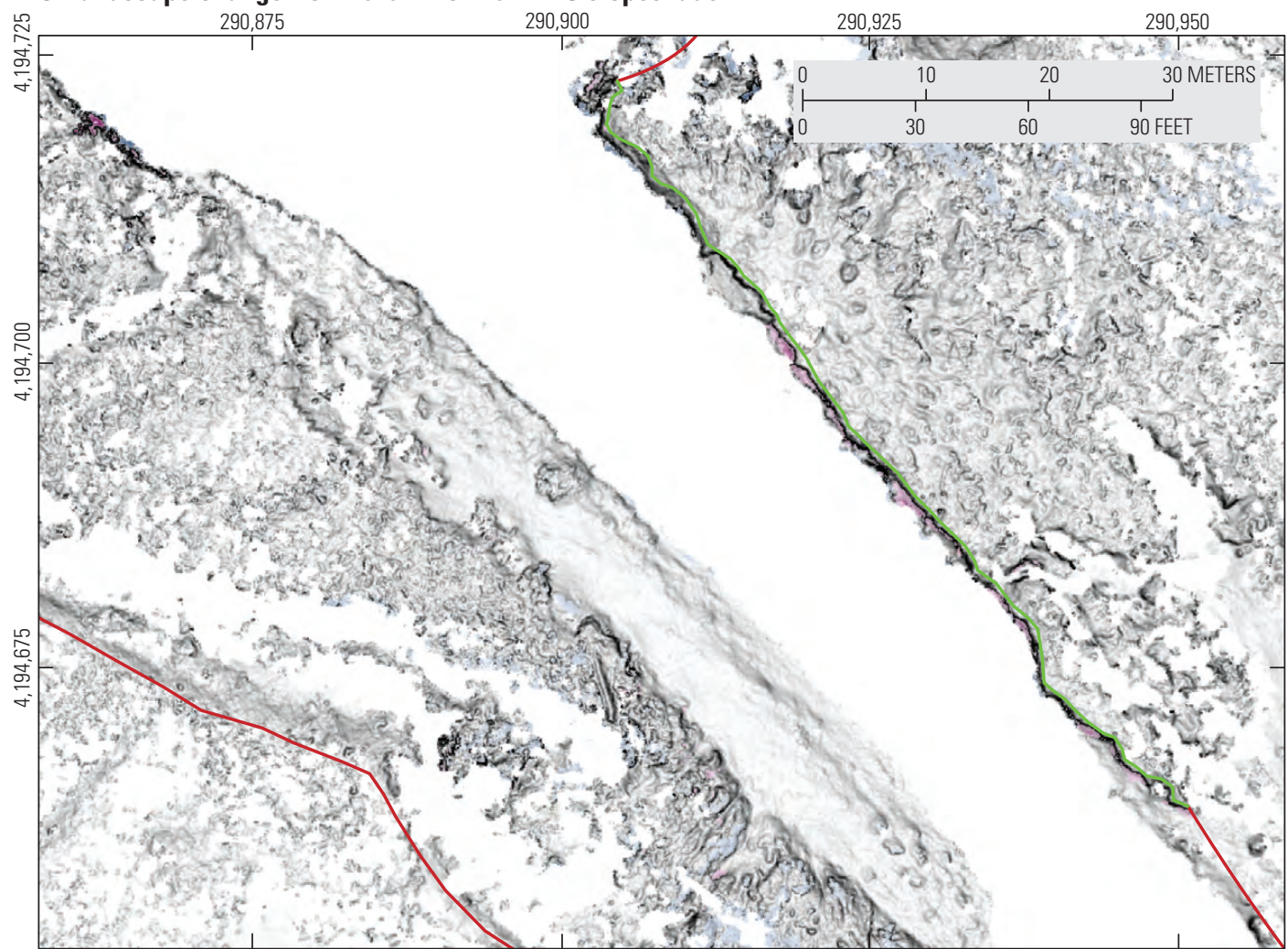

\section{EXPLANATION}

Elevation change, in meters

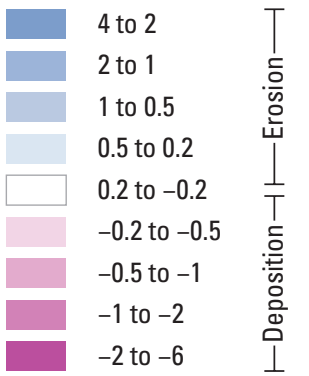

2017 streambanks

—_ Indistinct/stable Steep/active

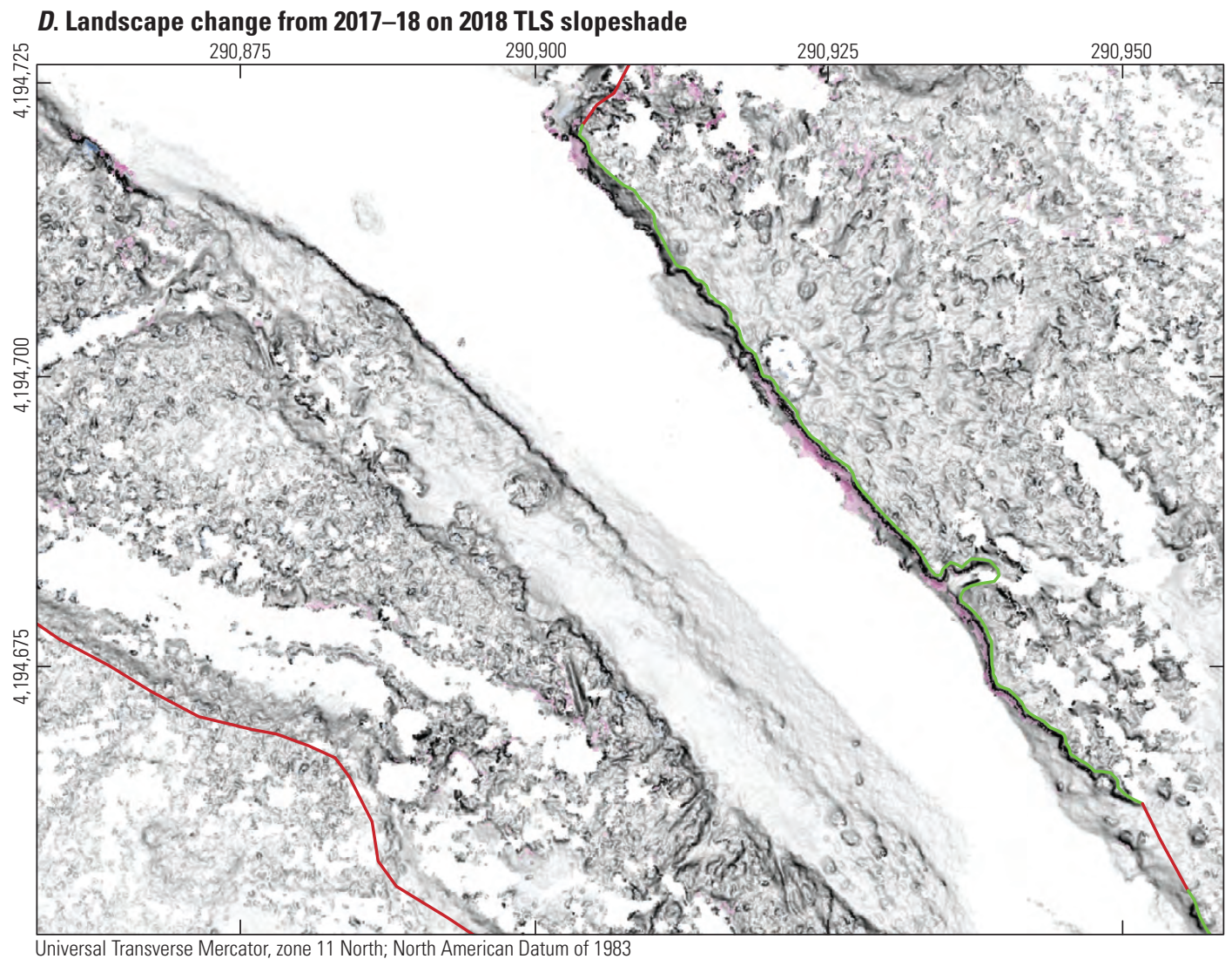

\section{EXPLANATION}

Elevation change, in meters

4 to 2
2 to 1
1 to 0.5
0.5 to 0.2
0.2 to -0.2
-0.2 to -0.5
-0.5 to -1
-1 to -2
-2 to -6

2018 streambanks

— Indistinct/stable Steep/active

Figure 29.-Continued 
A. Vegetation canopy height from 2018 TLS data

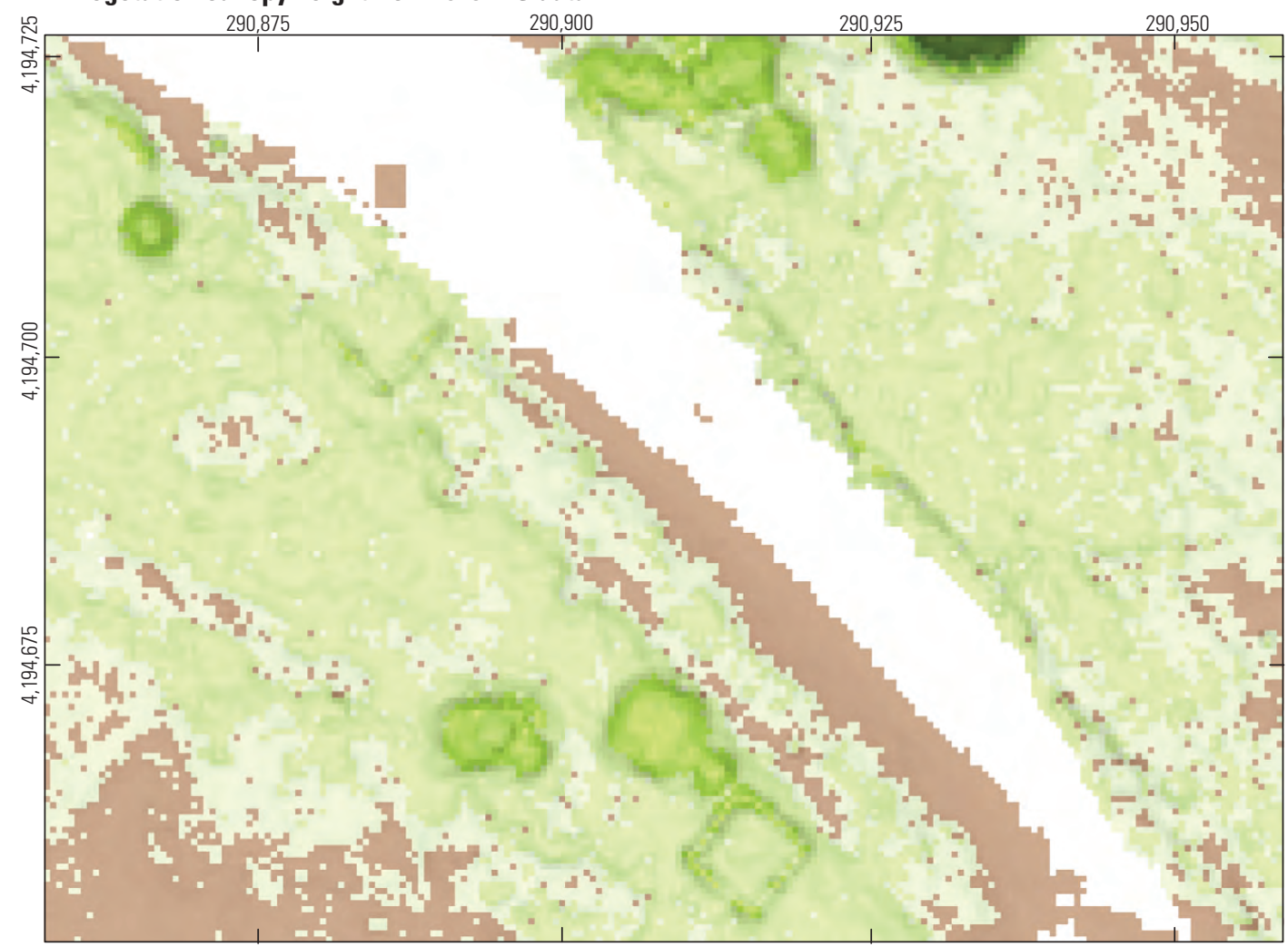

EXPLANATION

Canopy height, in meters

$<0.1$

0.1 to 0.25

0.25 to 1

1 to 2

2 to 4

4 to 10

10 to 20

20 to 30

30 to 50

$B$. Presence of streambank willows and other meadow vegetation from 2018 TLS data

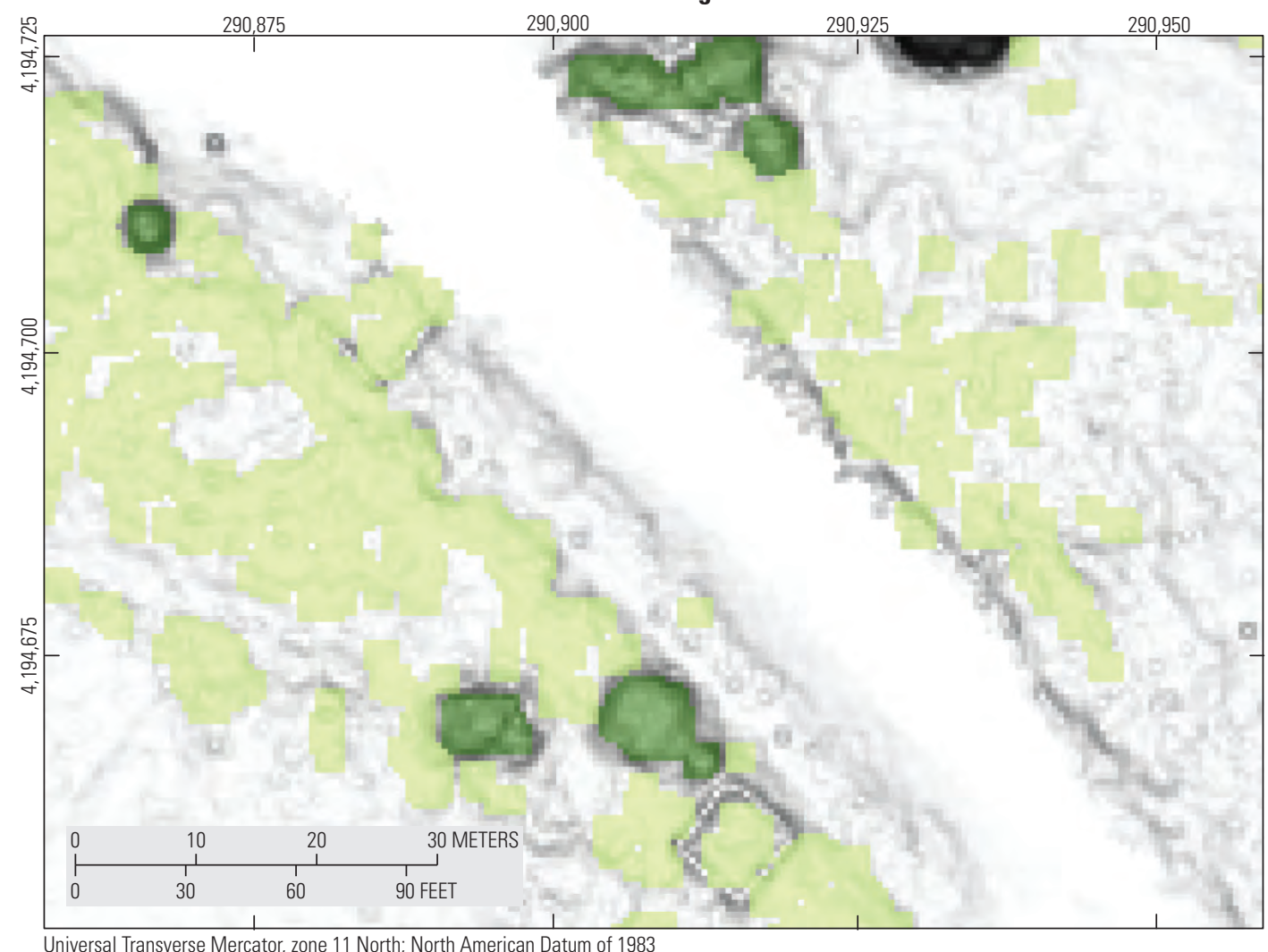

EXPLANATION

Canopy height, in meters

0.25 to 1 -Short vegetation

1 to 4 -Mostly willows

Universal Transverse Mercator, zone 11 North; North American Datum of 1983

Figure 30. Lidar-derived maps of vegetation at erosion zone 8. Data are from 2018 terrestrial laser scanning (TLS). $A$, shows a semitransparent canopy-height model over full-feature slopeshade. $B$, shows a map of vegetation most likely to be streambank willows and meadow vegetation. 

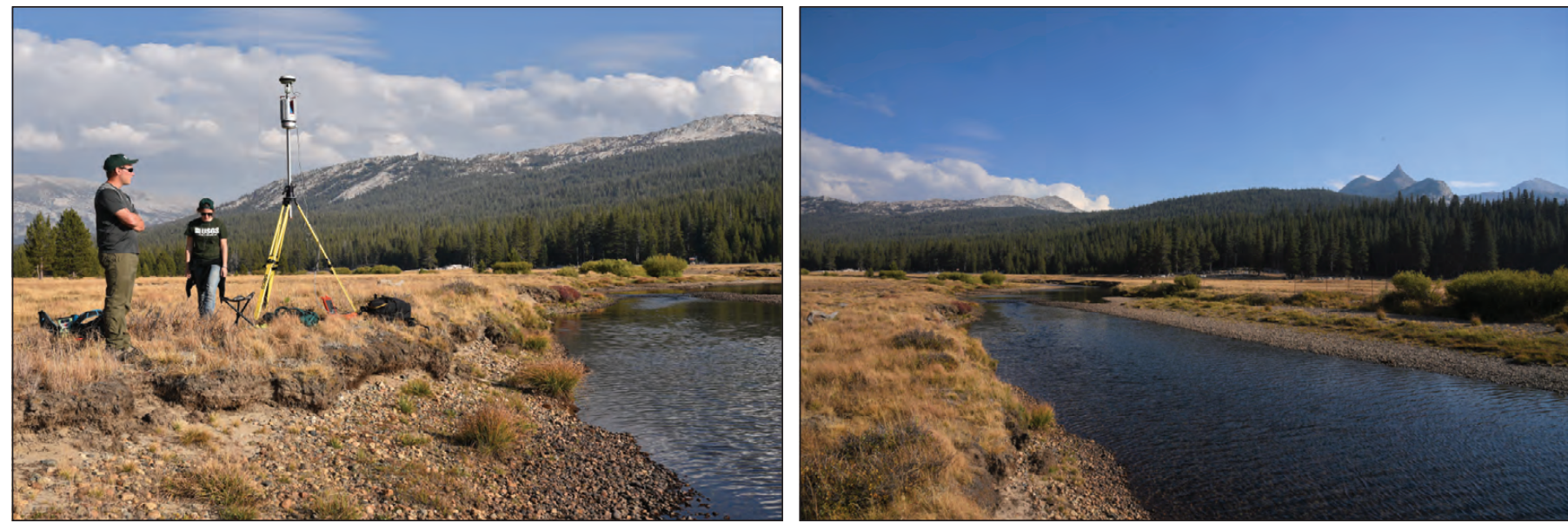

Figure 31. U.S. Geological Survey photographs of erosion zone 8, taken in 2016.

\section{Erosion Zone 9}

Erosion zone 9 encompasses a long, gently sweeping bend of the Tuolumne River where about $200 \mathrm{~m}$ of eroding streambank is opposite of a large depositional point bar (fig. 32). The streambank is eroding grass-covered soil and fluvial sediment and is approaching a slope where pine trees are growing (figs. 33 and 34). From 2006 to 2016 between 109 and $117 \mathrm{~m}^{3}$ of sediment was eroded from the streambank as it retreated an average of $0.38 \mathrm{~m}$ (table 11). During this time, the point bar eroded about $60 \mathrm{~m}^{3}$ of sediment. From 2016 to 2018 , about $260 \mathrm{~m}^{3}$ of sediment was deposited on the point bar, mostly during the 2017 flood, and streambank erosion removed between about 26 and $330 \mathrm{~m}^{3}$ of sediment. The wide range in erosion estimates is caused by material remaining along the streambanks as indicated by the low DoD-derived estimate and the high streambank mappingderived estimate which appears to overestimate true erosion. The streambank retreated an average of $1.15 \mathrm{~m}$ in 2017, and not at all in 2018. Over the entire study period of 2006-2018, the bank eroded between 81 and $440 \mathrm{~m}^{3}$, though the high end of that is an overestimate based on examination of streambank mapping and the topographic products that reveal substantial sediment storage between mapped streambank positions. From 2006 to 2018 about $251 \mathrm{~m}^{3}$ of sediment was deposited on the point bar, some of which accumulated behind and adjacent to a log that was deposited transverse to flow direction on the bar (fig. 32).

Table 11. Estimates of erosion and deposition at erosion zone 9 along Tuolumne River.

[---, no data; DEM, digital elevation model; DoD, DEMs of difference; $\mathrm{m}$, meter; $\mathrm{m}^{2}$, square meter; $\mathrm{m}^{3}$, cubic meter]

\begin{tabular}{|c|c|c|c|c|c|c|c|c|}
\hline \multirow[b]{2}{*}{$\begin{array}{c}\text { Erosion } \\
\text { zone }\end{array}$} & \multirow[b]{2}{*}{$\begin{array}{l}\text { Surveyed } \\
\text { interval }\end{array}$} & \multirow[b]{2}{*}{$\begin{array}{c}\text { Streambank } \\
\text { or bar }\end{array}$} & \multicolumn{2}{|c|}{ From DEM change mapping } & \multicolumn{4}{|c|}{ From streambank mapping } \\
\hline & & & $\begin{array}{l}\text { Area of data } \\
\text { in zone }\left(\mathrm{m}^{2}\right)\end{array}$ & $\begin{array}{l}\text { Volume change } \\
\text { from } \operatorname{DoD}\left(\mathrm{m}^{3}\right)\end{array}$ & $\begin{array}{c}\text { Active } \\
\text { streambank } \\
\text { length }(\mathrm{m})\end{array}$ & $\begin{array}{c}\text { Bank } \\
\text { height }(\mathrm{m})\end{array}$ & $\begin{array}{l}\text { Average bank } \\
\text { retreat }(\mathrm{m})\end{array}$ & $\begin{array}{c}\text { Volume change } \\
\text { from streambank } \\
\text { mapping }\left(\mathrm{m}^{3}\right)\end{array}$ \\
\hline 9 & 2006-2016 & Bank & 1,556 & a- -116.5 & 205 & 1.40 & 0.38 & -109.1 \\
\hline 9 & 2006-2017 & Bar & 2,049 & a335.4 & --- & --- & --- & --- \\
\hline 9 & 2006-2018 & Bank & 1,372 & a -80.7 & --- & --- & --- & --- \\
\hline 9 & $2016-2017$ & Bar & 1,671 & b224.5 & --- & --- & --- & --- \\
\hline 9 & 2016-2017 & Bank & 825 & b -6.9 & 205 & 1.40 & 1.15 & -330.1 \\
\hline 9 & $2017-2018$ & Bar & 1,670 & $\mathrm{~b}-1.3$ & --- & --- & --- & --- \\
\hline 9 & 2017-2018 & Bank & 804 & b-14.8 & 150 & 1.40 & 0.0 & 0.0 \\
\hline
\end{tabular}

${ }^{\mathrm{a}}$ Calculated from 50-cm-resolution digital elevation models at 4-cm level of detection.

${ }^{\mathrm{b}}$ Calculated from 10-cm-resolution digital elevation models at 2-cm level of detection. 


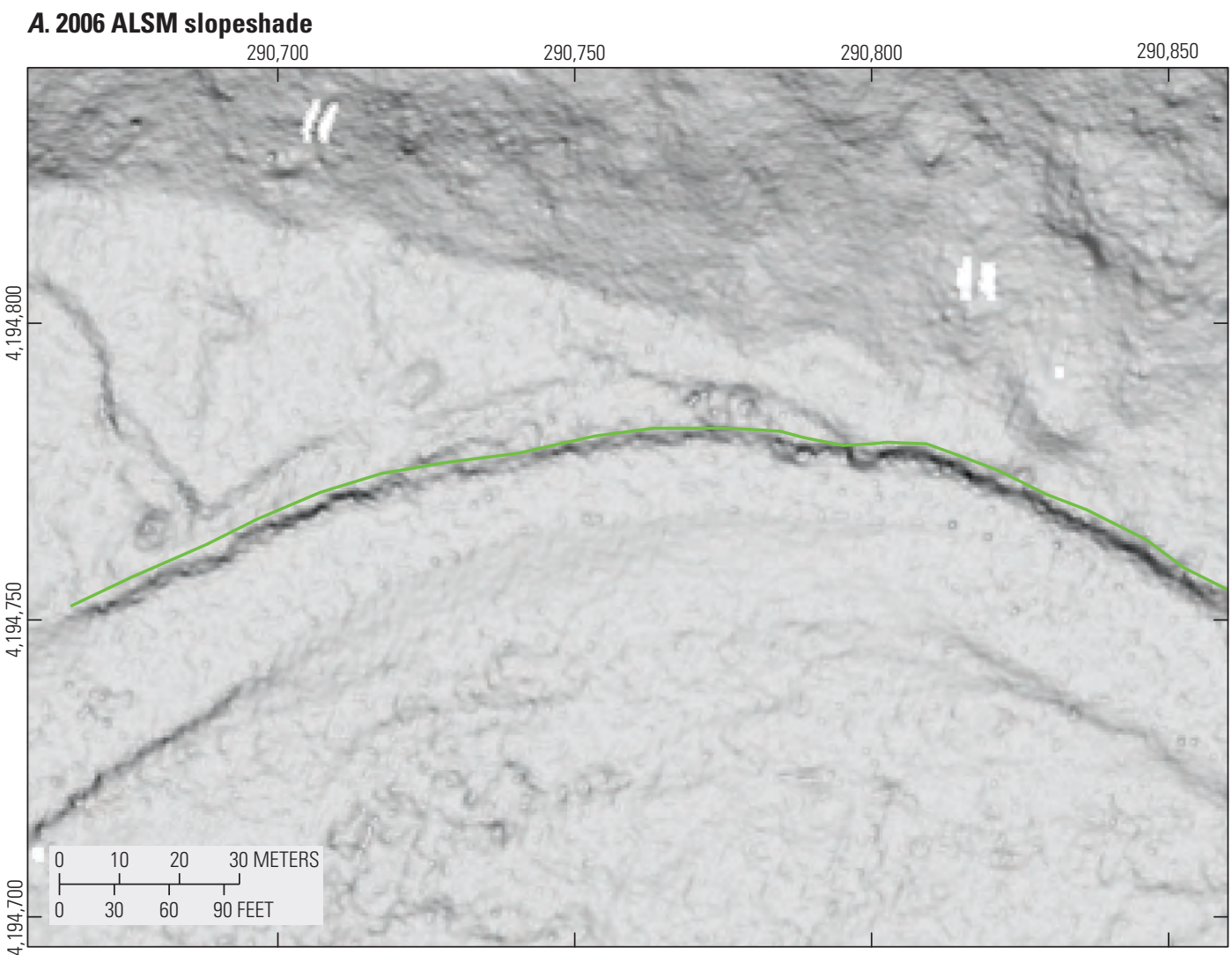

EXPLANATION

2006 streambanks

_ Indistinct/stable

- Steep/active

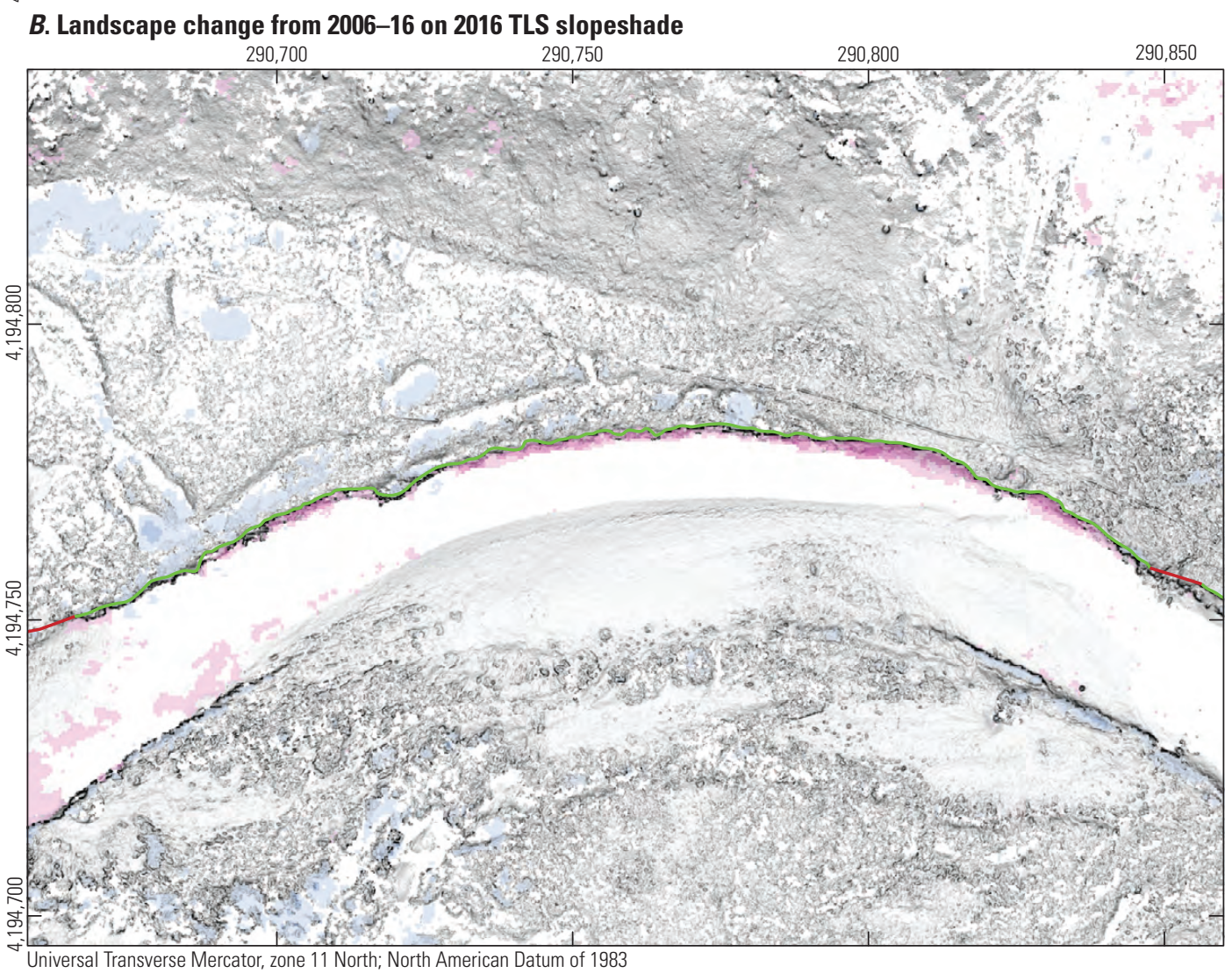

\section{EXPLANATION}

Elevation change, in meters

\begin{tabular}{|l|}
\hline 4 to 2 \\
2 to 1 \\
1 to 0.5 \\
0.5 to 0.2 \\
0.2 to -0.2 \\
-0.2 to -0.5 \\
-0.5 to -1 \\
-1 to -2 \\
-2 to -6 \\
\hline
\end{tabular}

2016 streambanks

_ Indistinct/stable Steep/active

Figure 32. Lidar-derived maps showing location and classification of stream banks at erosion zone 9. A, 2006 airborne laser swath mapping (ALSM) bare-earth slopeshade with mapped streambanks. B, 2016 terrestrial laser scanning (TLS) bare-earth slopeshade. C, 2017 TLS bare-earth slopeshade. D, 2018 TLS bare-earth slopeshade. Colors indicate geomorphic change, and lines are mapped streambanks. 
C. Landscape change from 2016-17 on 2017 TLS slopeshade
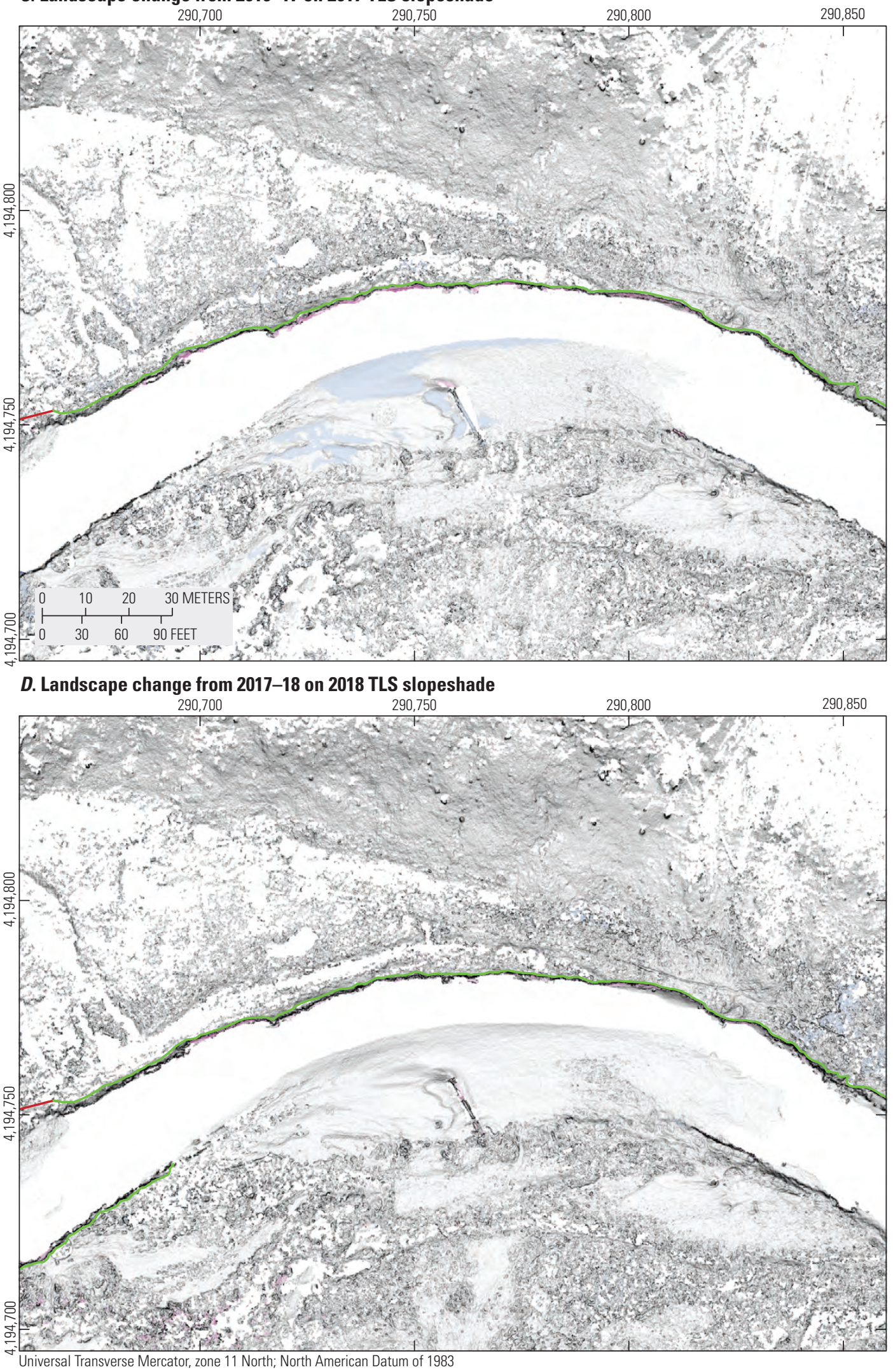

\section{EXPLANATION}

Elevation change, in meters

\begin{tabular}{|l|}
4 to 2 \\
2 to 1 \\
1 to 0.5 \\
0.5 to 0.2 \\
0.2 to -0.2 \\
-0.2 to -0.5 \\
-0.5 to -1 \\
-1 to -2 \\
-2 to -6
\end{tabular}

2017 streambanks

— Indistinct/stable Steep/active

\section{EXPLANATION}

Elevation change, in meters

4 to 2
2 to 1
1 to 0.5
0.5 to 0.2
0.2 to -0.2
-0.2 to -0.5
-0.5 to -1
-1 to -2
-2 to -6

2018 streambanks

—_ Indistinct/stable Steep/active

Figure 32.-Continued 
A. Vegetation canopy height from 2018 TLS data

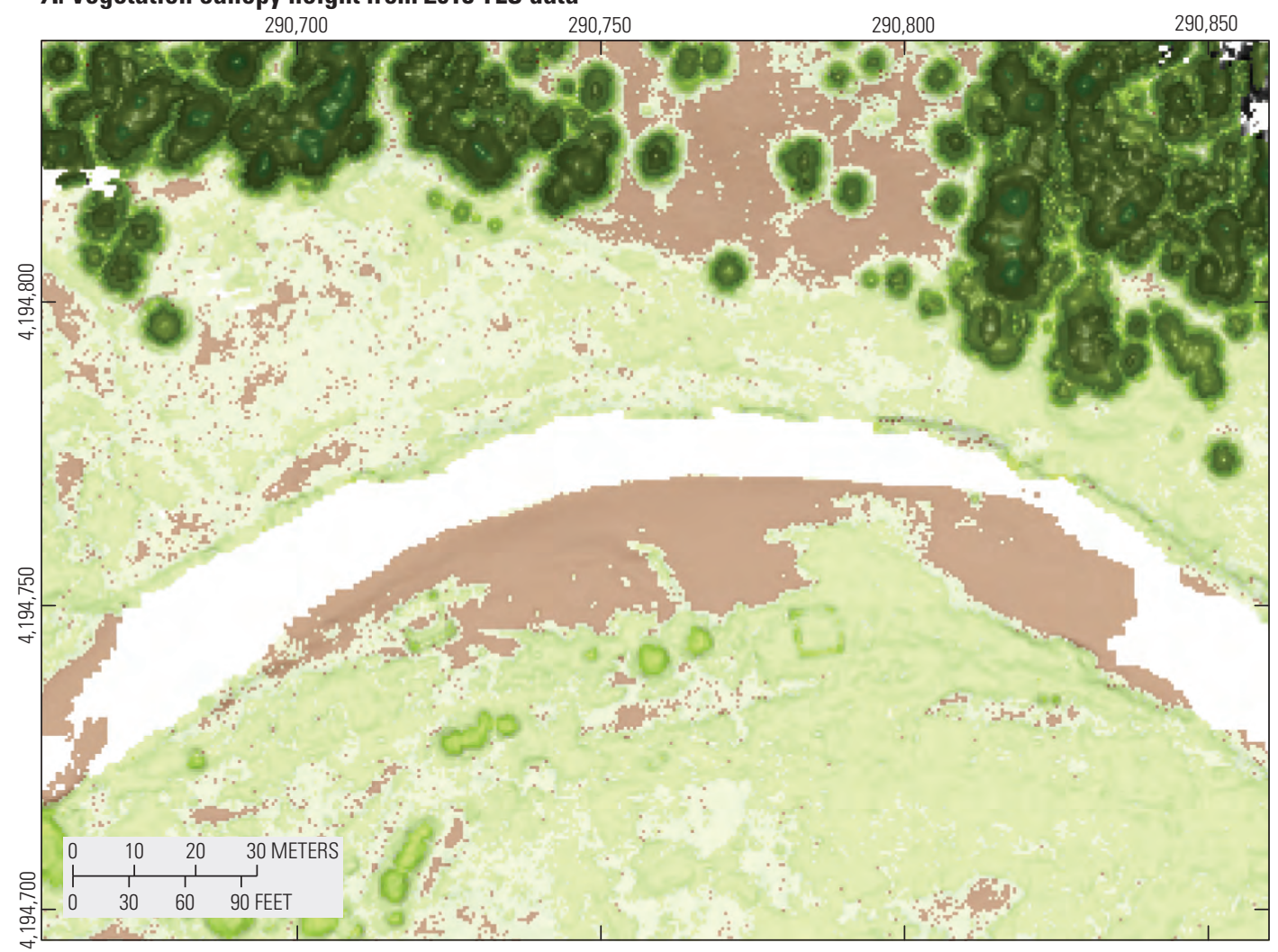

\section{EXPLANATION}

Canopy height, in meters

$<0.1$

0.1 to 0.25

0.25 to 1

1 to 2

2 to 4

4 to 10

10 to 20

20 to 30

30 to 50

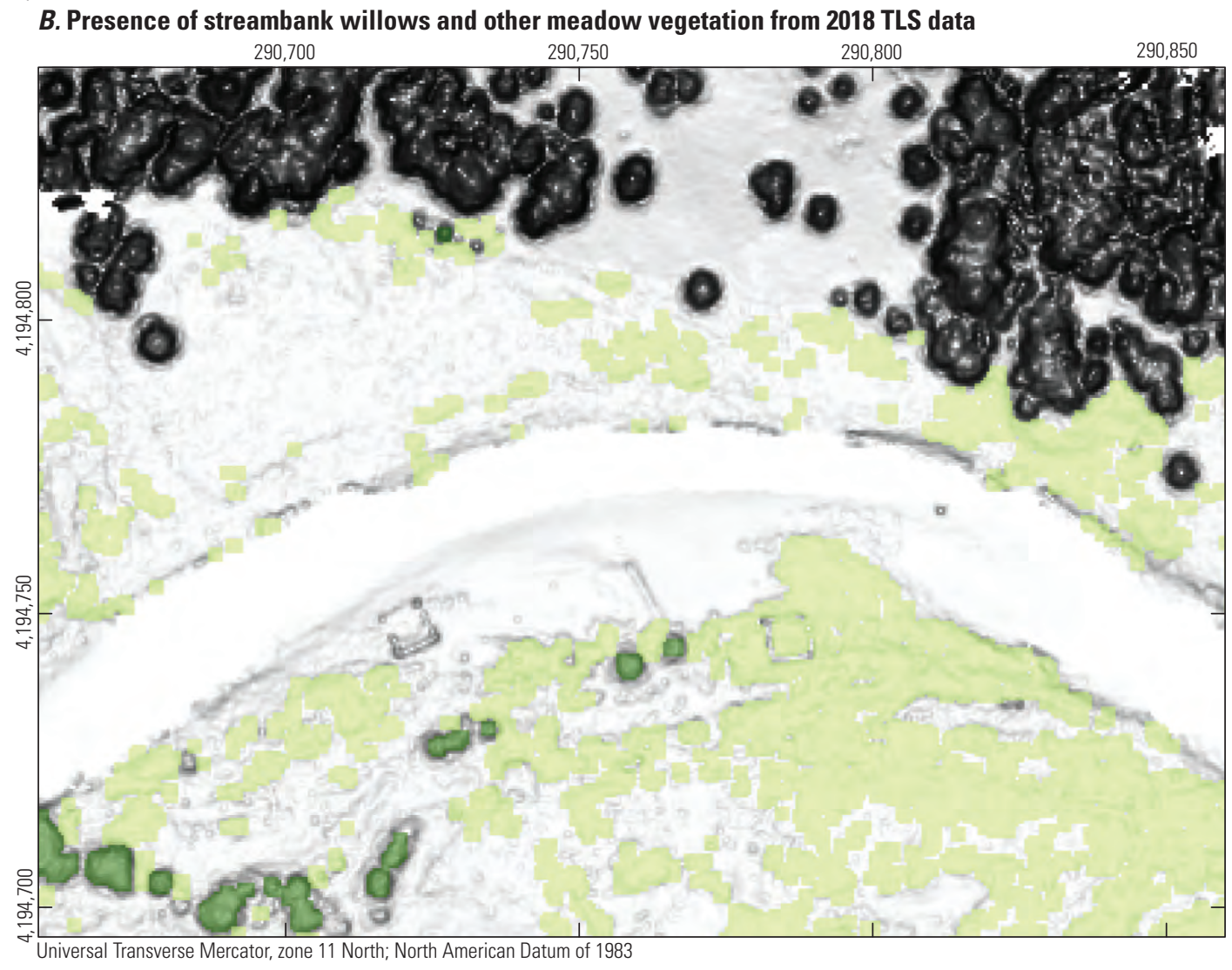

EXPLANATION

Canopy height, in meters

0.25 to 1 -Short vegetation

1 to 4 -Mostly willows

Figure 33. Lidar-derived maps of vegetation at erosion zone 9. Data are from 2018 terrestrial laser scanning (TLS). $A$, shows a semitransparent canopy-height model over full-feature slopeshade. $B$, shows a map of vegetation most likely to be streambank willows and meadow vegetation. 

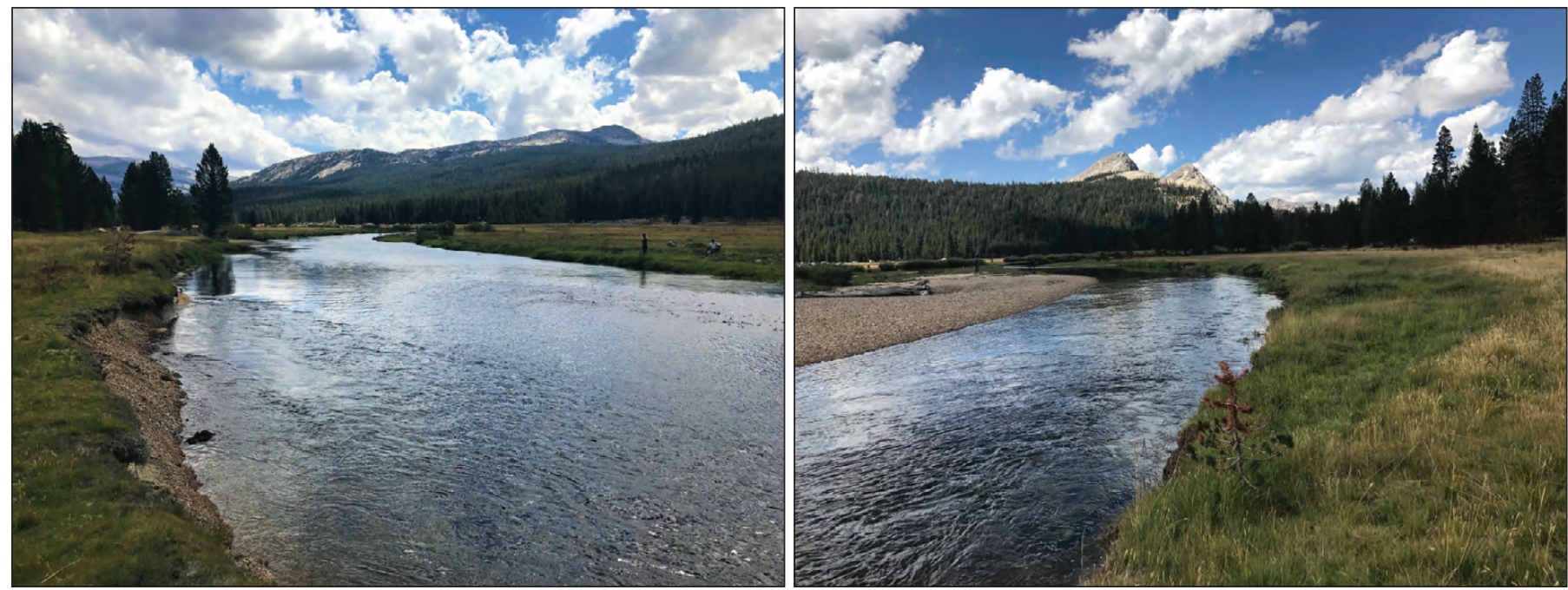

Figure 34. U.S. Geological Survey photographs of erosion zone 9, taken in 2016.

\section{Erosion Zone 10}

Erosion zone 10 is at a sharp bend just upstream of an even sharper bend in the Tuolumne River (fig. 35). The streambank is eroding a grass and willow-covered surface that is underlain by soil and fluvial sediment (figs. 36 and 37). The eroding streambank is opposite of a large point bar and just upstream of a channel bar that may be a remnant of a point bar that was cutoff as the channel changed position sometime prior to 2006. This remnant bar is likely the old point bar across from a steep, active-looking streambank that did not erode during the study period, therefore it is not included as an erosion zone.
From 2006 to 2016, the streambank in this zone retreated an average of about $3.65 \mathrm{~m}$, leading to between about 279 and $473 \mathrm{~m}^{3}$ of erosion (table 12). During this period, the point bar only received about $12 \mathrm{~m}^{3}$ of sediment deposition. Erosion continued at the streambank through 2018 as it retreated an average of about $2.7 \mathrm{~m}$ in 2017 and $1.33 \mathrm{~m}$ in 2018. From 2016 to 2018, between about 94 and $341 \mathrm{~m}^{3}$ of material was eroded. From 2016 to 2018 about $172 \mathrm{~m}^{3}$ of sediment was deposited on the point bar, most of which occurred in 2017. Over the entire study period 2006 to $2018,246 \mathrm{~m}^{3}$ of sediment was deposited in this zone, and between 279 and $814 \mathrm{~m}^{3}$ of sediment was eroded from the streambank. This was the most active streambank in the study in terms of distance of retreat, though it was relatively short at less than $90 \mathrm{~m}$.

Table 12. Estimates of erosion and deposition at erosion zone 10 along Tuolumne River.

[---, no data; DEM, digital elevation model; DoD, DEMs of difference; $\mathrm{m}$, meter; $\mathrm{m}^{2}$, square meter; $\mathrm{m}^{3}$, cubic meter]

\begin{tabular}{|c|c|c|c|c|c|c|c|c|}
\hline \multirow[b]{2}{*}{$\begin{array}{l}\text { Erosion } \\
\text { zone }\end{array}$} & \multirow[b]{2}{*}{$\begin{array}{l}\text { Surveyed } \\
\text { interval }\end{array}$} & \multirow[b]{2}{*}{$\begin{array}{c}\text { Streambank } \\
\text { or bar }\end{array}$} & \multicolumn{2}{|c|}{ From DEM change mapping } & \multicolumn{4}{|c|}{ From streambank mapping } \\
\hline & & & $\begin{array}{l}\text { Area of data } \\
\text { in zone }\left(\mathrm{m}^{2}\right)\end{array}$ & $\begin{array}{l}\text { Volume change } \\
\text { from } D_{0} D\left(m^{3}\right)\end{array}$ & $\begin{array}{c}\text { Active } \\
\text { streambank } \\
\text { length }(\mathrm{m})\end{array}$ & $\begin{array}{c}\text { Bank } \\
\text { height }(m)\end{array}$ & $\begin{array}{c}\text { Average bank } \\
\text { retreat }(\mathrm{m})\end{array}$ & $\begin{array}{c}\text { Volume change } \\
\text { from streambank } \\
\text { mapping }\left(\mathrm{m}^{3}\right)\end{array}$ \\
\hline 10 & 2006-2016 & Bank & 631 & a-279.4 & 90 & 1.40 & 3.75 & -472.5 \\
\hline 10 & 2006-2017 & Bar & 1,691 & a311.1 & --- & --- & --- & --- \\
\hline 10 & 2006-2018 & Bank & 482 & a-278.9 & --- & --- & --- & --- \\
\hline 10 & 2016-2017 & Bar & 1,277 & b149.1 & --- & --- & --- & --- \\
\hline 10 & 2016-2017 & Bank & 237 & $\mathrm{~b}-35.0$ & 76 & 1.40 & 2.70 & -287.3 \\
\hline 10 & 2017-2018 & Bar & 1,326 & b-33.7 & --- & --- & --- & --- \\
\hline 10 & 2017-2018 & Bank & 212 & b-60.0 & 29 & 1.40 & 1.33 & -54.0 \\
\hline
\end{tabular}

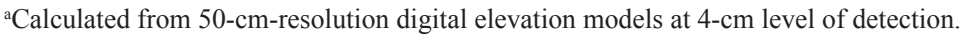

${ }^{\mathrm{b}}$ Calculated from $10-\mathrm{cm}$-resolution digital elevation models at 2-cm level of detection. 


\section{A. 2006 ALSM slopeshade}

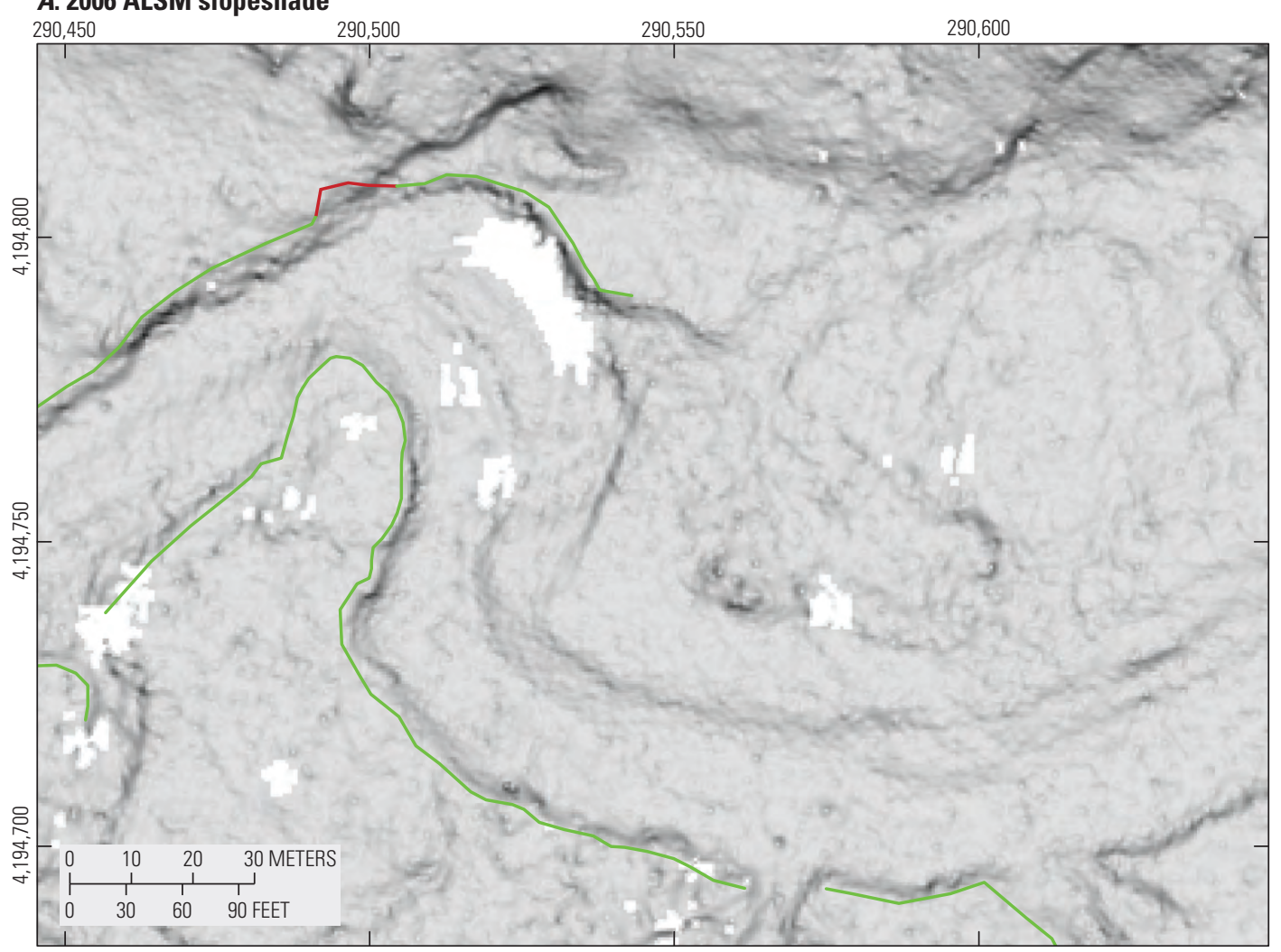

\section{EXPLANATION}

2006 streambanks

- Indistinct/stable

- Steep/active

\section{B. Landscape change from $2006-16$ on 2016 TLS slopeshade}

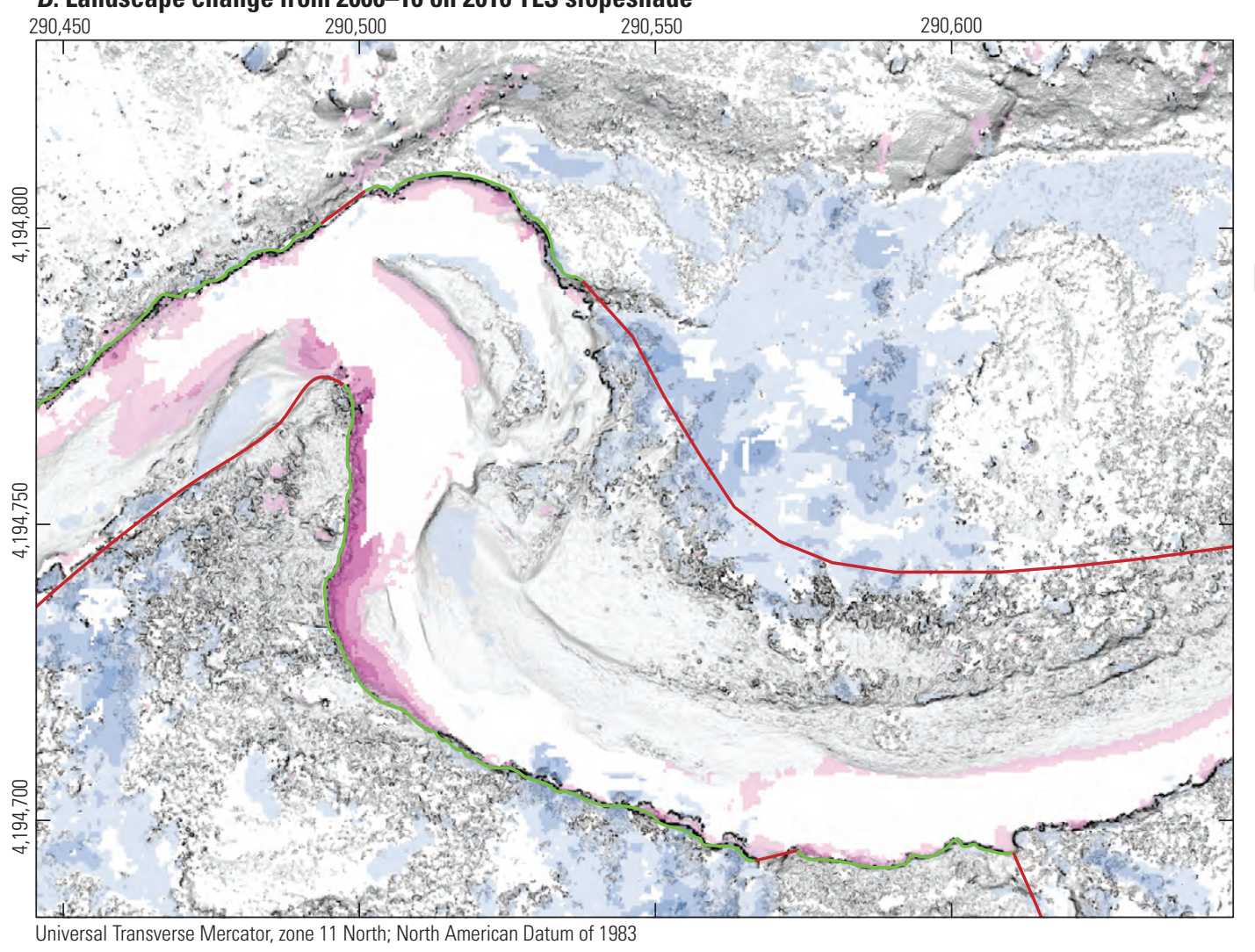

\section{EXPLANATION}

Elevation change, in meters

4 to 2

2 to 1

1 to 0.5

0.5 to 0.2

0.2 to -0.2

-0.2 to -0.5

-0.5 to -1

-1 to -2

-2 to -6

2016 streambanks

__ Indistinct/stable

Steep/active

Figure 35. Lidar-derived maps showing location and classification of stream banks at erosion zone 10. $A$, 2006 airborne laser swath mapping (ALSM) bare-earth slopeshade with mapped streambanks. B, 2016 terrestrial laser scanning (TLS) bare-earth slopeshade. C, 2017 TLS bare-earth slopeshade. D, 2018 TLS bare-earth slopeshade. Colors indicate geomorphic change and lines are mapped streambanks. 
C. Landscape change from 2016-17 on 2017 TLS slopeshade

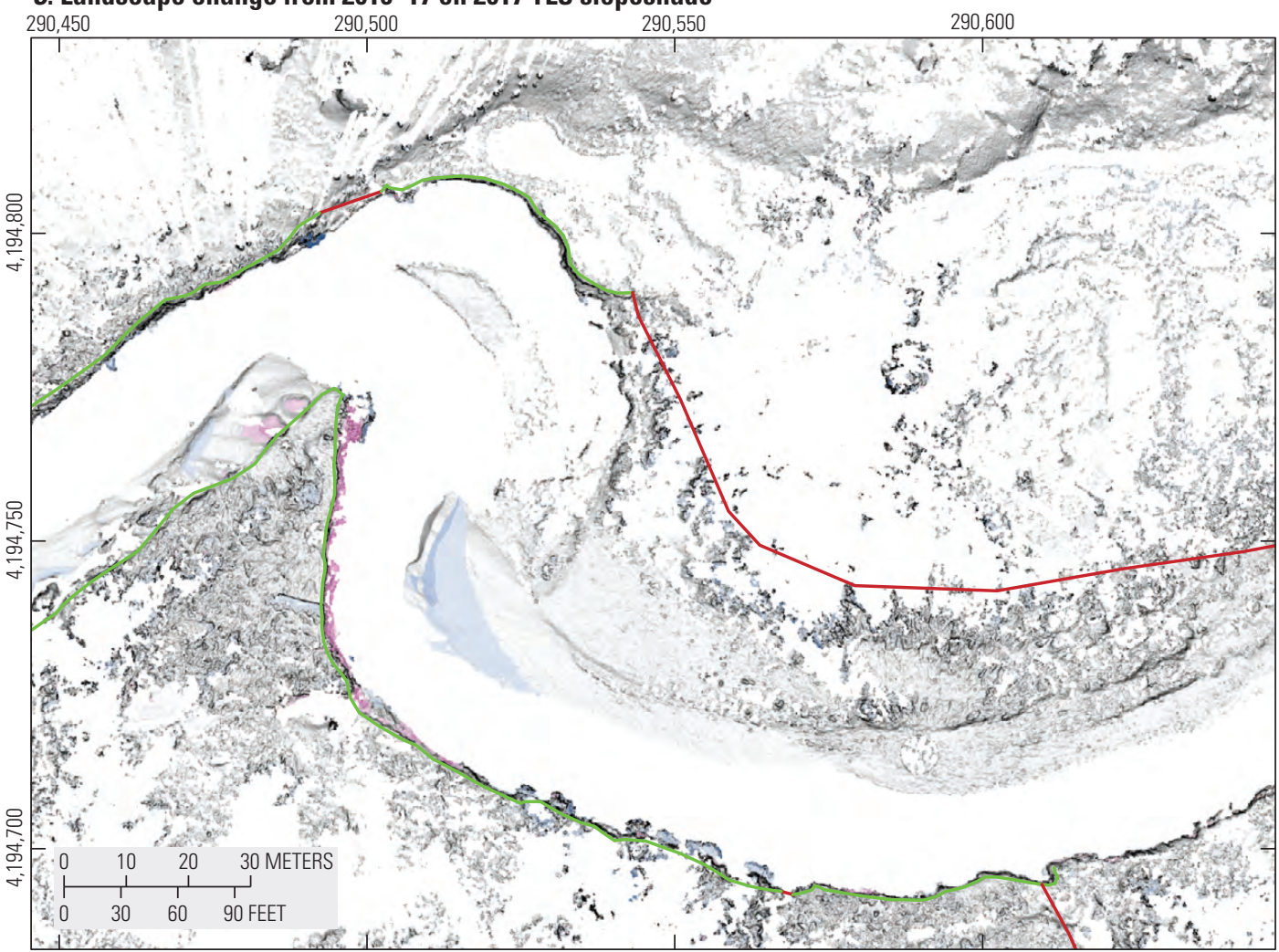

D. Landscape change from 2017-18 on 2018 TLS slopeshade

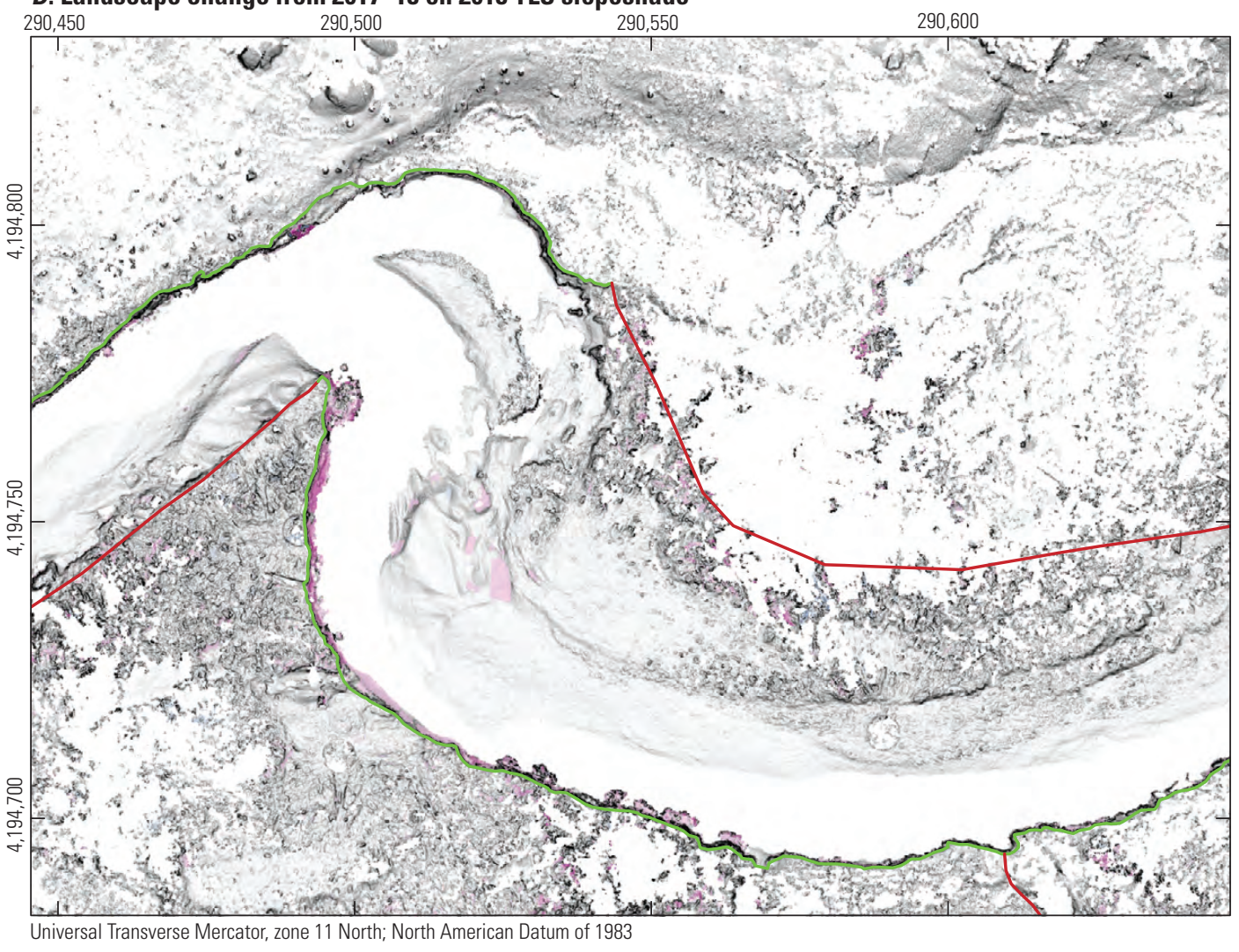

\section{EXPLANATION}

Elevation change, in meters

4 to 2

2 to 1

1 to 0.5

0.5 to 0.2

0.2 to -0.2

-0.2 to -0.5

-0.5 to -1

-1 to -2

-2 to -6

2018 streambanks

_ Indistinct/stable Steep/active

Figure 35.-Continued 


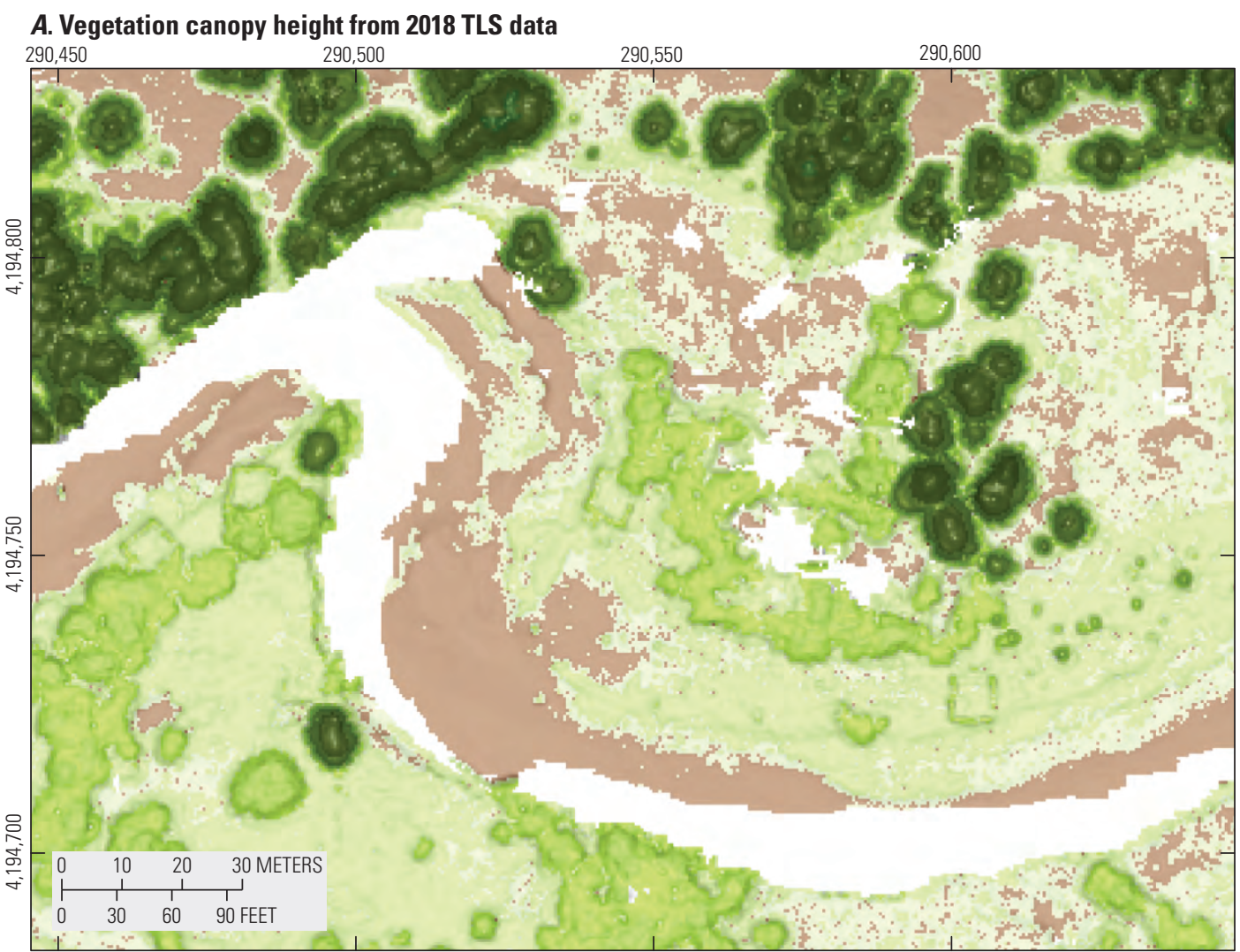

\section{EXPLANATION}

Canopy height, in meters $<0.1$

\section{1 to 0.25}

0.25 to 1

1 to 2

2 to 4

4 to 10

10 to 20

20 to 30

30 to 50

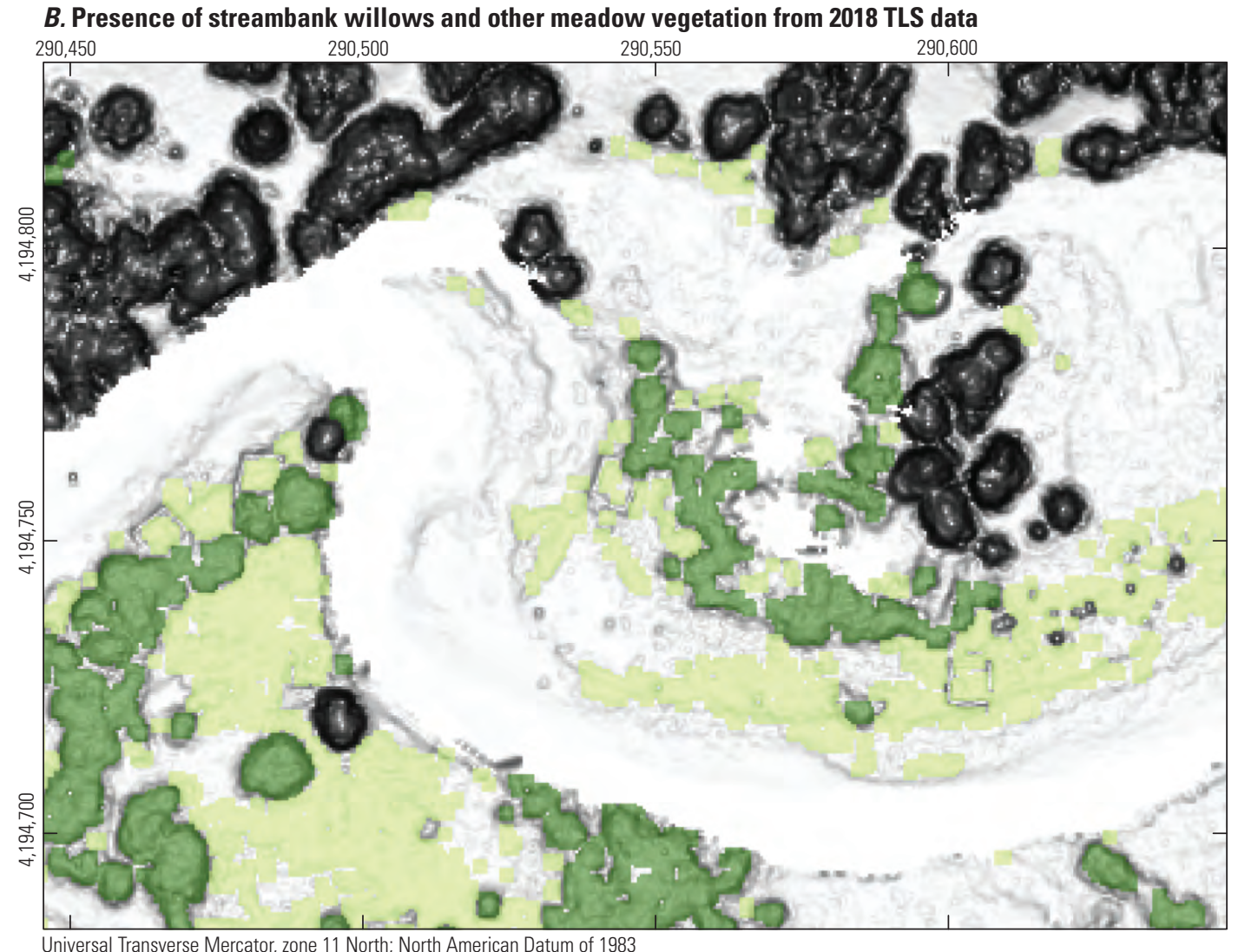

EXPLANATION

Canopy height, in meters

0.25 to 1 - Short vegetation

1 to $4-$ Mostly willows

Figure 36. Lidar-derived maps of vegetation at erosion zone 10. Data are from 2018 terrestrial laser scanning (TLS). $A$, shows a semitransparent canopy-height model over full-feature slopeshade. $B$, shows a map of vegetation most likely to be streambank willows and meadow vegetation. 

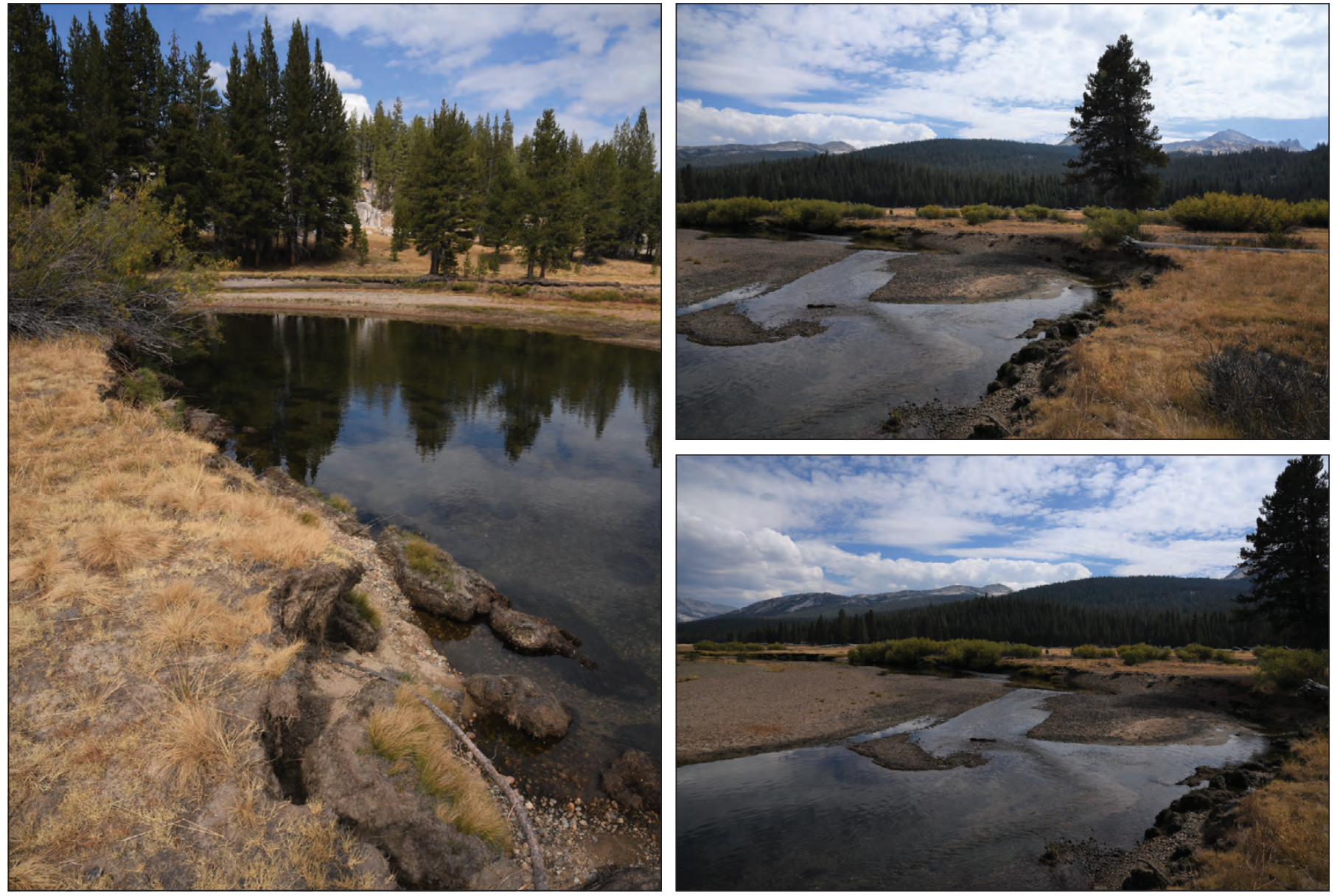

Figure 37. U.S. Geological Survey photographs of erosion zone 10, taken in 2016.

\section{Erosion Zone 11}

Erosion zone 11 is along a gradual bend of the Tuolumne River. It is across from and a bit downstream of a large point bar and just upstream of a large channel bar (fig. 38). The streambank is eroding a grass-covered surface underlain by soil and fluvial sediment along a length of about $35 \mathrm{~m}$ (figs. 39 and 40). The streambank retreated an average of $0.40 \mathrm{~m}$ from 2006 to 2016, eroding between about 12 and $48 \mathrm{~m}^{3}$ of sediment from the streambank (table 13). The point bar opposite of the streambank also eroded during this time period, losing about $20 \mathrm{~m}^{3}$ of sediment. From 2016 to 2017 the streambank retreated about $1.4 \mathrm{~m}$, and from 2017 to 2018 the streambank retreated an average of about $0.25 \mathrm{~m}$. From 2016 to 2018, erosion at the streambank of between about 16 and $52 \mathrm{~m}^{3}$ was exceeded by deposition of about $104 \mathrm{~m}^{3}$ of sediment on the opposite point bar. Over the entire study period, erosion of between about 58 and $64 \mathrm{~m}^{3}$ was exceeded by deposition of $110 \mathrm{~m}^{3}$ of sediment on the opposite point bar. 
A. 2006 ALSM slopeshade

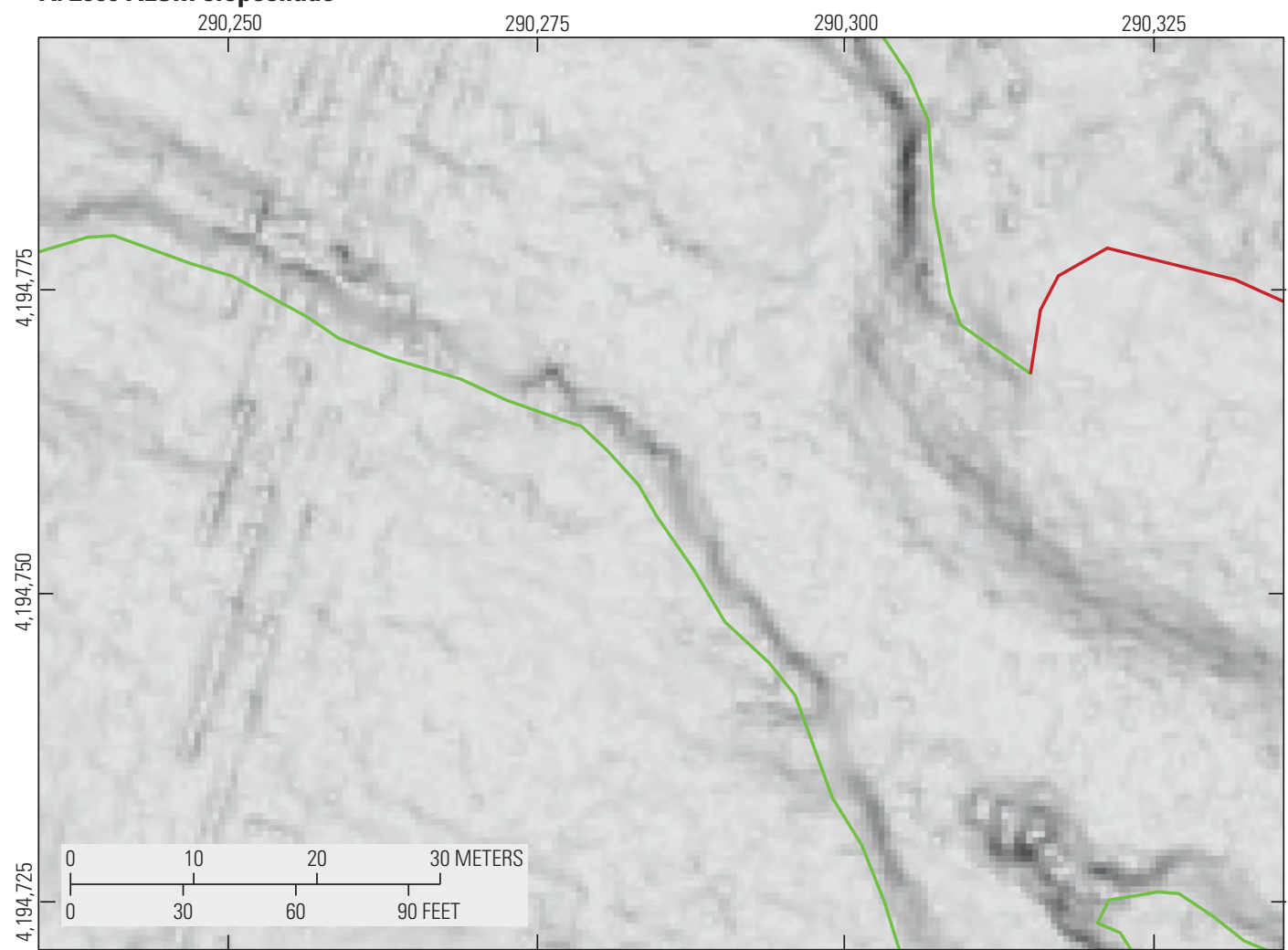

EXPLANATION

2006 streambanks

_ Indistinct/stable

- Steep/active

\section{B. Landscape change from 2006-16 on 2016 TLS slopeshade}

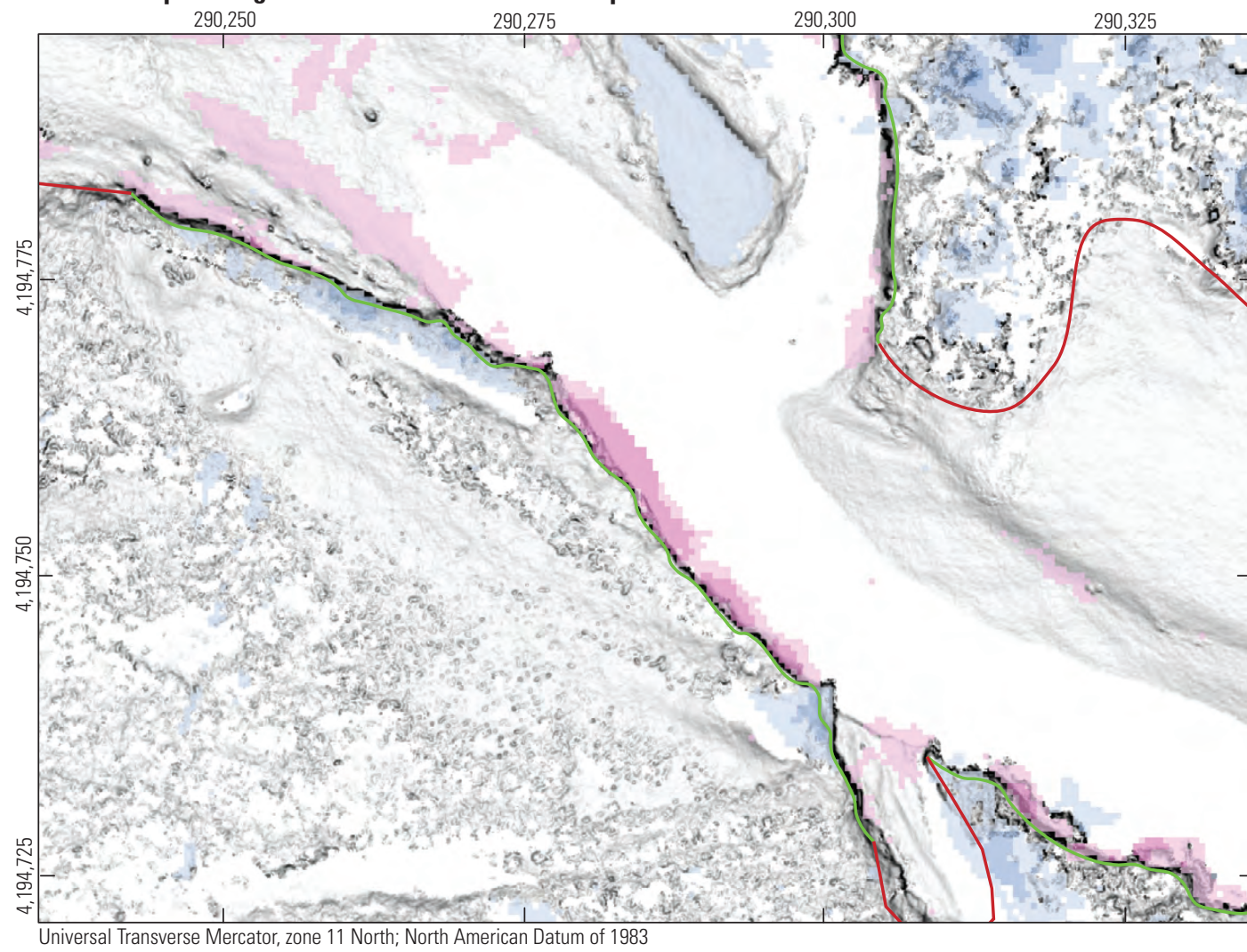

\section{EXPLANATION}

Elevation change, in meters

4 to 2

2 to 1

1 to 0.5

0.5 to 0.2

0.2 to -0.2

-0.2 to -0.5

-0.5 to -1

-1 to -2

-2 to -6

2016 streambanks

_- Indistinct/stable

- Steep/active

Figure 38. Lidar-derived maps showing location and classification of stream banks at erosion zone 11. A, 2006 airborne laser swath mapping (ALSM) bare-earth slopeshade with mapped streambanks. $B, 2016$ terrestrial laser scanning (TLS) bare-earth slopeshade. C, 2017 TLS bare-earth slopeshade. D, 2018 TLS bare-earth slopeshade. Colors indicate geomorphic change and lines are mapped streambanks. 


\section{Landscape change from 2016-17 on 2017 TLS slopeshade}
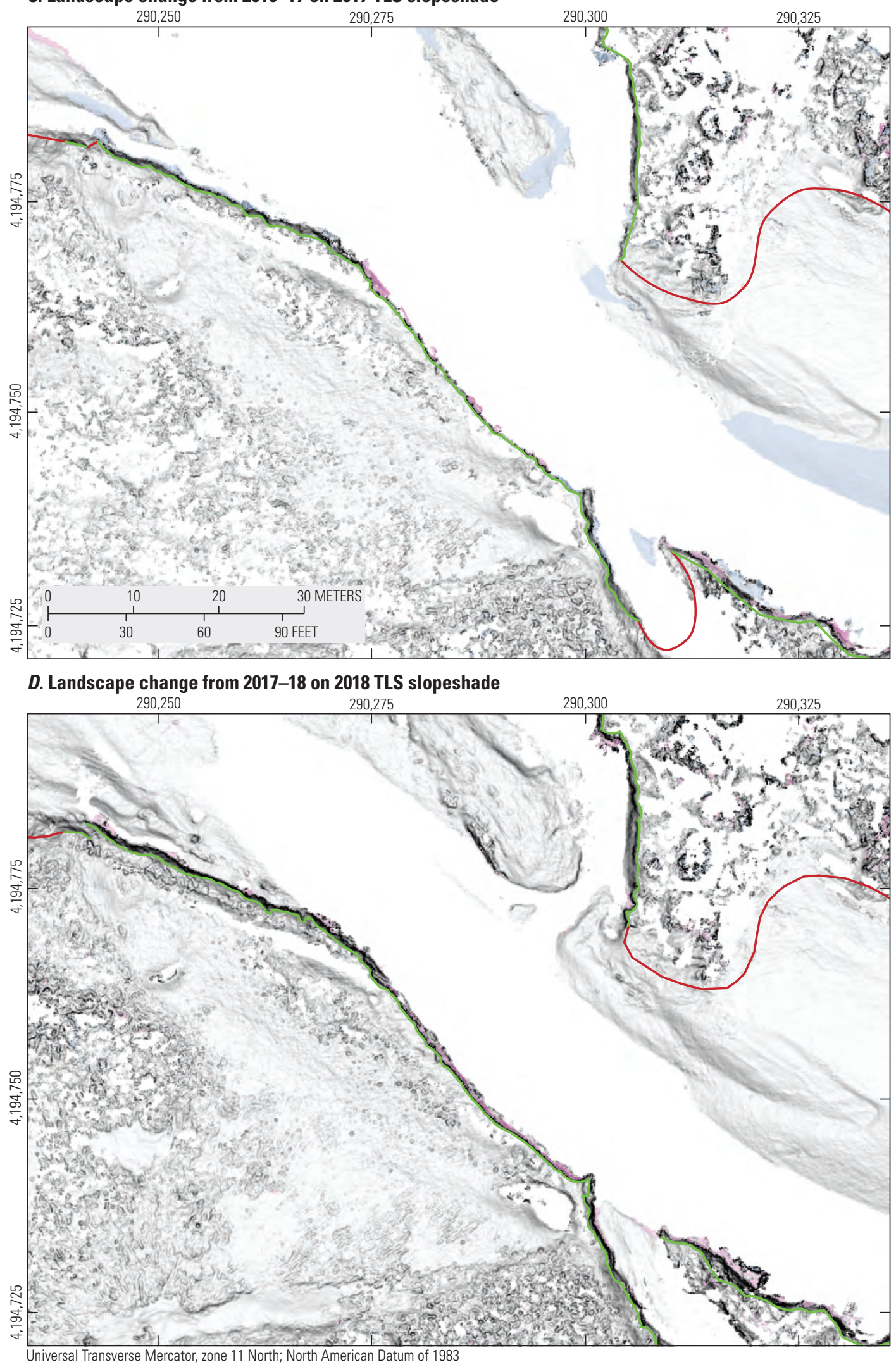

\section{EXPLANATION}

Elevation change, in meters

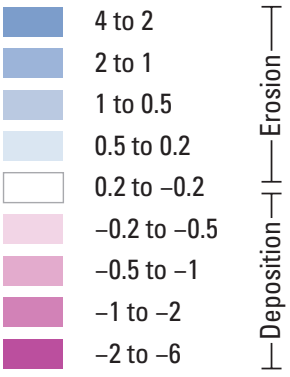

2018 streambanks

_ Indistinct/stable

Steep/active

Figure 38.-Continued 
A. Vegetation canopy height from 2018 TLS data

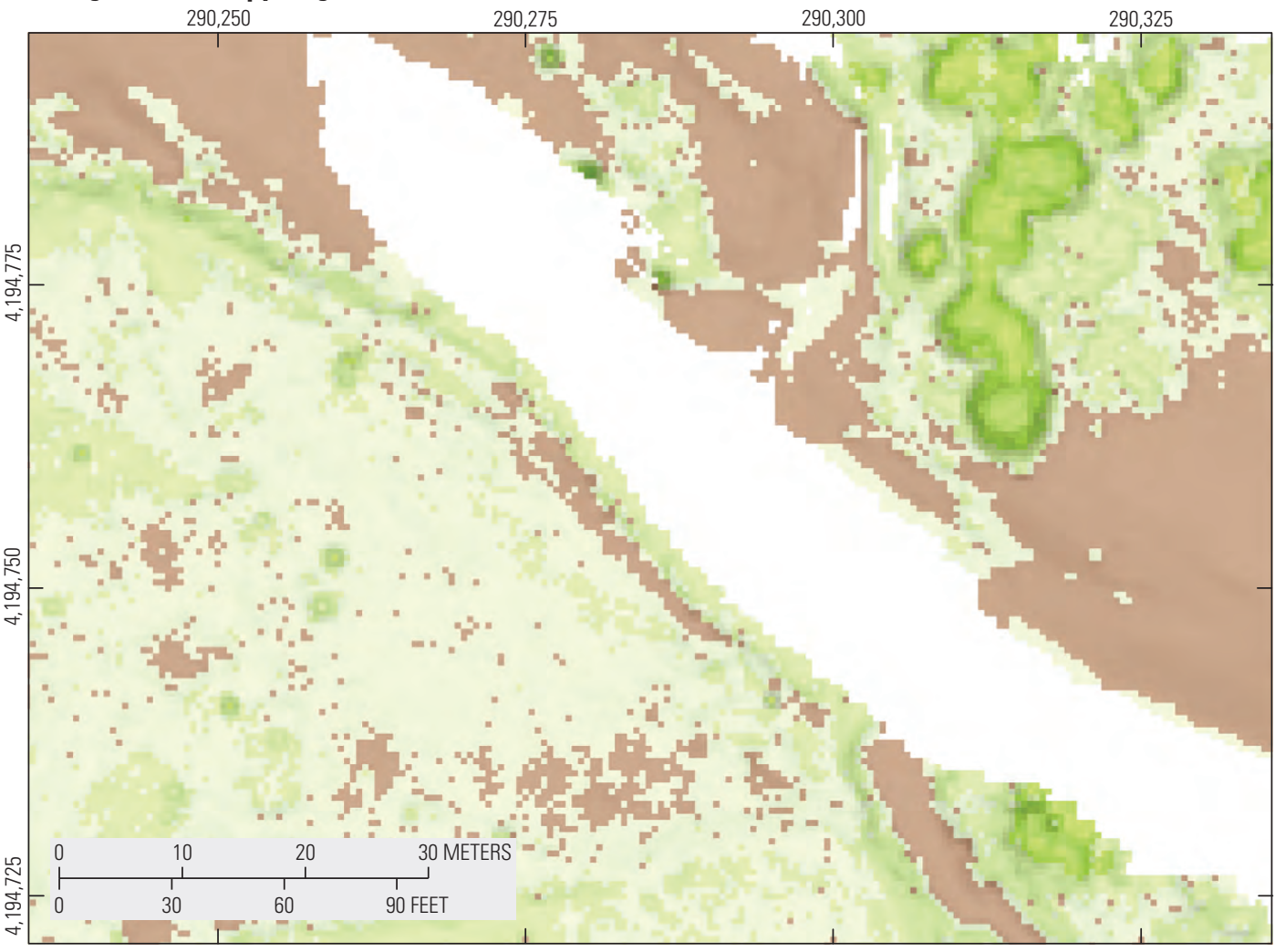

\section{EXPLANATION}

Canopy height, in meters

$<0.1$

0.1 to 0.25

0.25 to 1

1 to 2

2 to 4

4 to 10

10 to 20

20 to 30

30 to 50

\section{B. Presence of streambank willows and other meadow vegetation from 2018 TLS data}

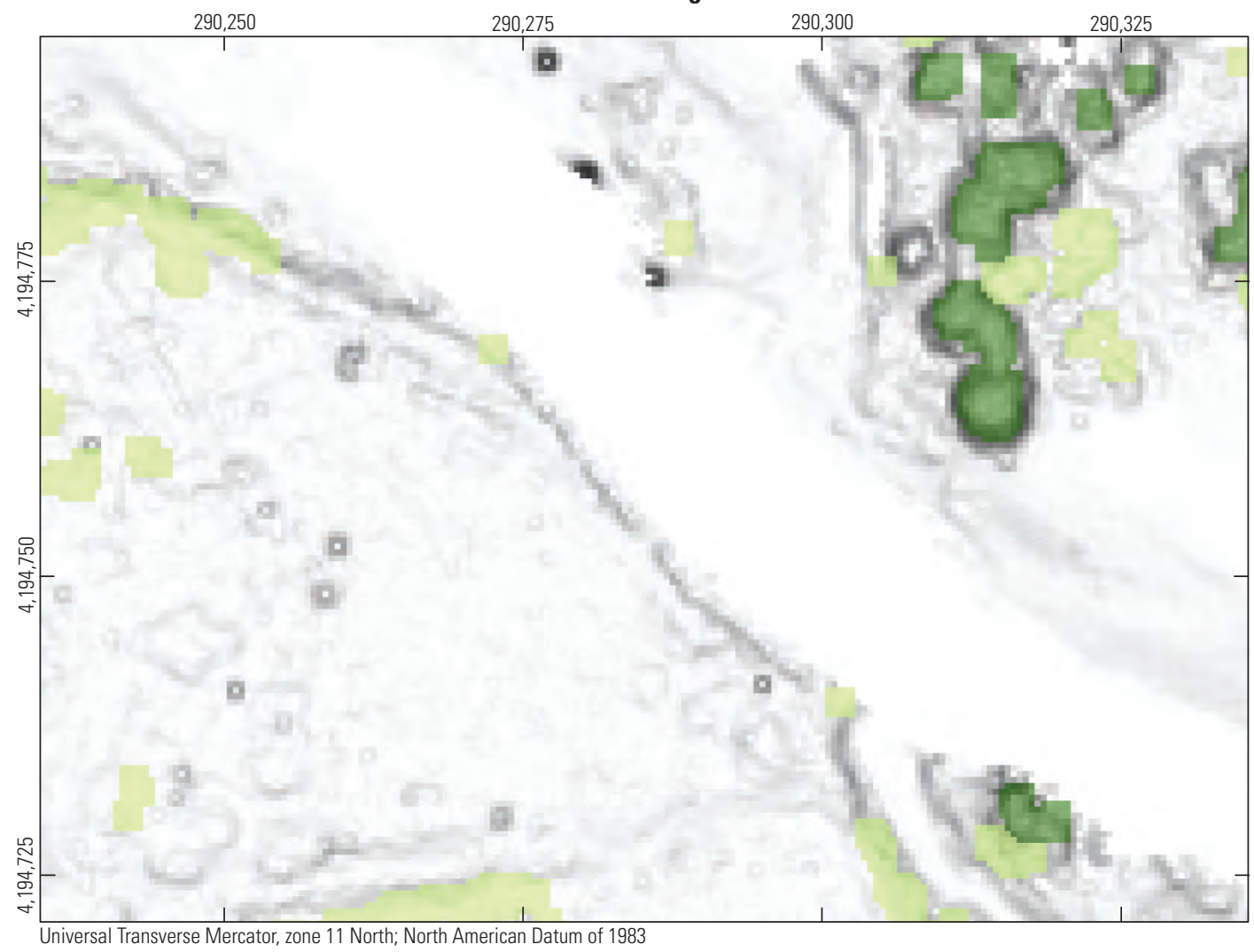

EXPLANATION

Canopy height, in meters 0.25 to 1 -Short vegetation 1 to $4-$ Mostly willows

Figure 39. Lidar-derived maps of vegetation at erosion zone 11. Data are from 2018 terrestrial laser scanning (TLS). $A$, shows a semitransparent canopy-height model over full-feature slopeshade. $B$, shows a map of vegetation most likely to be streambank willows and meadow vegetation. 
Figure 40. U.S. Geological Survey photograph of erosion zone 11, taken in 2016.

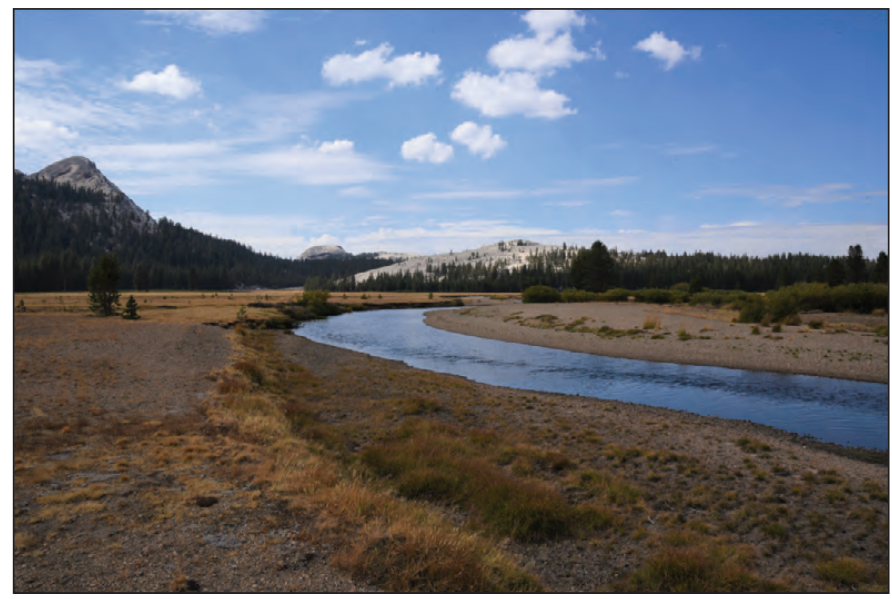

Table 13. Estimates of erosion and deposition at erosion zone 11 along Tuolumne River.

[---, no data; DEM, digital elevation model; DoD, DEMs of difference; m, meter; $\mathrm{m}^{2}$, square meter; $\mathrm{m}^{3}$, cubic meter]

\begin{tabular}{|c|c|c|c|c|c|c|c|c|}
\hline \multirow[b]{2}{*}{$\begin{array}{l}\text { Erosion } \\
\text { zone }\end{array}$} & \multirow[b]{2}{*}{$\begin{array}{l}\text { Surveyed } \\
\text { interval }\end{array}$} & \multirow[b]{2}{*}{$\begin{array}{c}\text { Streambank } \\
\text { or bar }\end{array}$} & \multicolumn{2}{|c|}{ From DEM change mapping } & \multicolumn{4}{|c|}{ From streambank mapping } \\
\hline & & & $\begin{array}{l}\text { Area of data } \\
\text { in zone }\left(\mathrm{m}^{2}\right)\end{array}$ & $\begin{array}{l}\text { Volume change } \\
\text { from } \mathrm{DoD}\left(\mathrm{m}^{3}\right)\end{array}$ & $\begin{array}{c}\text { Active } \\
\text { streambank } \\
\text { length }(\mathbf{m})\end{array}$ & $\begin{array}{c}\text { Bank } \\
\text { height (m) }\end{array}$ & $\begin{array}{c}\text { Average bank } \\
\text { retreat }(\mathrm{m})\end{array}$ & $\begin{array}{c}\text { Volume change } \\
\text { from streambank } \\
\text { mapping }\left(\mathrm{m}^{3}\right)\end{array}$ \\
\hline 11 & 2006-2016 & Bank & 174 & a-47.7 & 34 & 0.90 & 0.40 & -12.2 \\
\hline 11 & $2006-2017$ & Bar & 1,548 & ${ }^{\mathrm{a}} 172.3$ & --- & --- & --- & --- \\
\hline 11 & $2006-2018$ & Bank & 136 & a -57.9 & --- & --- & --- & --- \\
\hline 11 & 2016-2017 & Bar & 1,375 & ${ }^{\mathrm{b}} 153.3$ & --- & --- & --- & --- \\
\hline 11 & 2016-2017 & Bank & 40 & $\mathrm{~b}-4.2$ & 35 & 0.90 & 1.40 & -44.1 \\
\hline 11 & $2017-2018$ & Bar & 1,384 & b-52.7 & --- & --- & --- & --- \\
\hline 11 & 2017-2018 & Bank & 42 & $\mathrm{~b}-7.0$ & 33 & 0.90 & 0.25 & -7.4 \\
\hline
\end{tabular}

${ }^{a}$ Calculated from 50-cm-resolution digital elevation models at 4-cm level of detection.

${ }^{\mathrm{b}} \mathrm{Calculated}$ from $10-\mathrm{cm}$-resolution digital elevation models at $2-\mathrm{cm}$ level of detection.

\section{Erosion Zone 12}

Erosion zone 12 is a broad horseshoe-shaped bend in the Tuolumne River (fig. 41). Here, the streambank is eroding a broad open grass-covered surface underlain by soil and fluvial sediment (figs. 42 and 43). The large point bar opposite the streambank hosts some willows along the more downstream portion. Along the apex of the bend in the river, a channel bar is at the base of the eroding streambank, and the low-water channel thalweg is between this channel bar and the large point bar opposite the eroding streambank. This channel bar did not provide protection from streambank erosion during the study period.
From 2006 to 2016 the streambank retreated an average of about $2.2 \mathrm{~m}$ over a length of $272 \mathrm{~m}$. This led to erosion of between about 778 and $827 \mathrm{~m}^{3}$ of sediment, and $403 \mathrm{~m}^{3}$ of sediment was deposited on the point and channel bar during this time (table 14). In 2017, the streambank retreated by about $0.86 \mathrm{~m}$ and in 2018 it retreated $0.4 \mathrm{~m}$, both times this retreat occurred over about $238 \mathrm{~m}$ of length. From 2016 to 2018 the streambank eroded between 112 and $390 \mathrm{~m}^{3}$ and the point bar had about $33 \mathrm{~m}^{3}$ of sediment deposited. For the entire study period 2006 to 2018 , the zone experienced between about 766 and about $1168 \mathrm{~m}^{3}$ of erosion and about $342 \mathrm{~m}^{3}$ of deposition. 
A. 2006 ALSM slopeshade

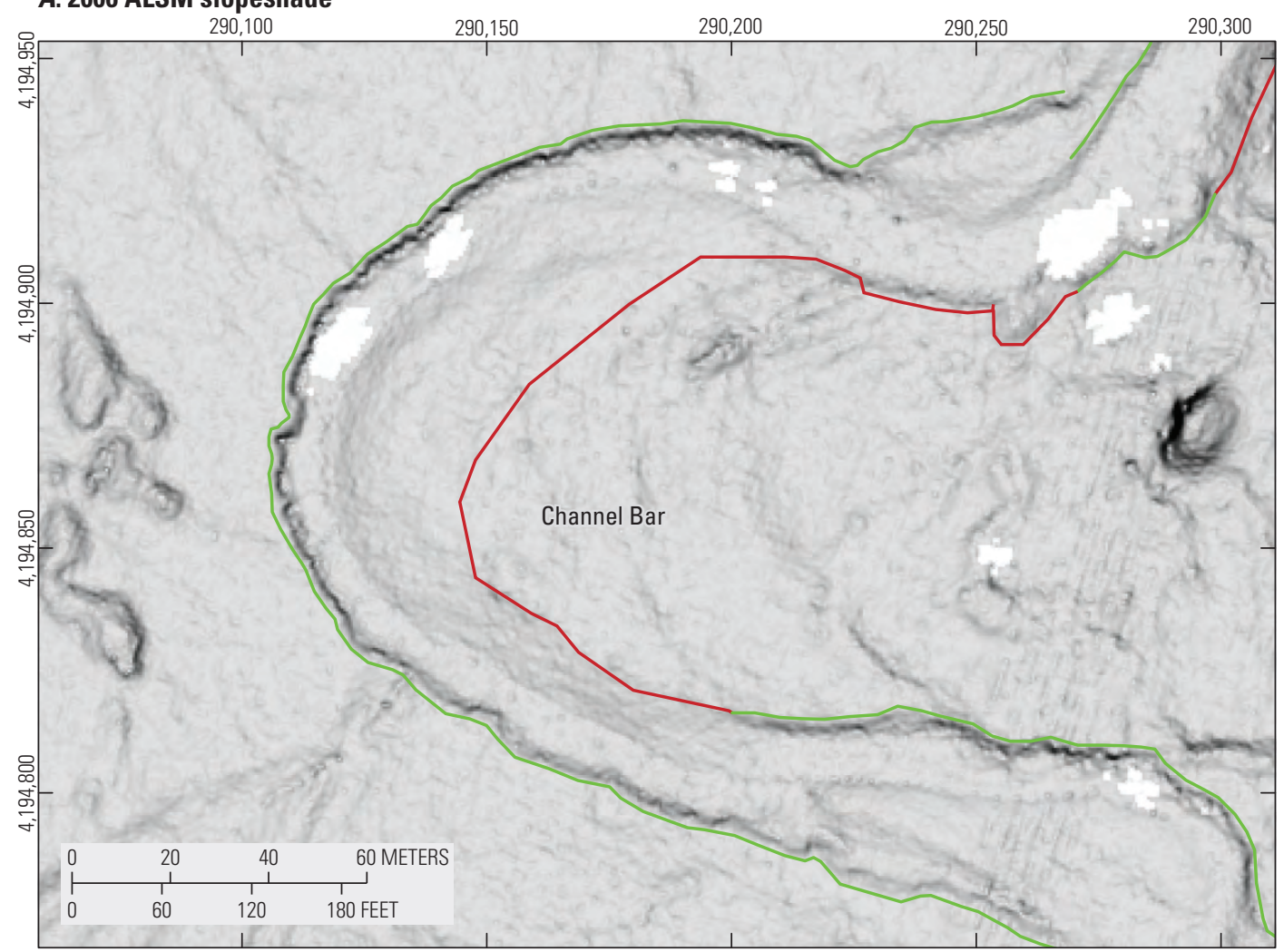

EXPLANATION

2006 streambanks

_ Indistinct/stable

— Steep/active

\section{B. Landscape change from 2006-16 on 2016 TLS slopeshade}

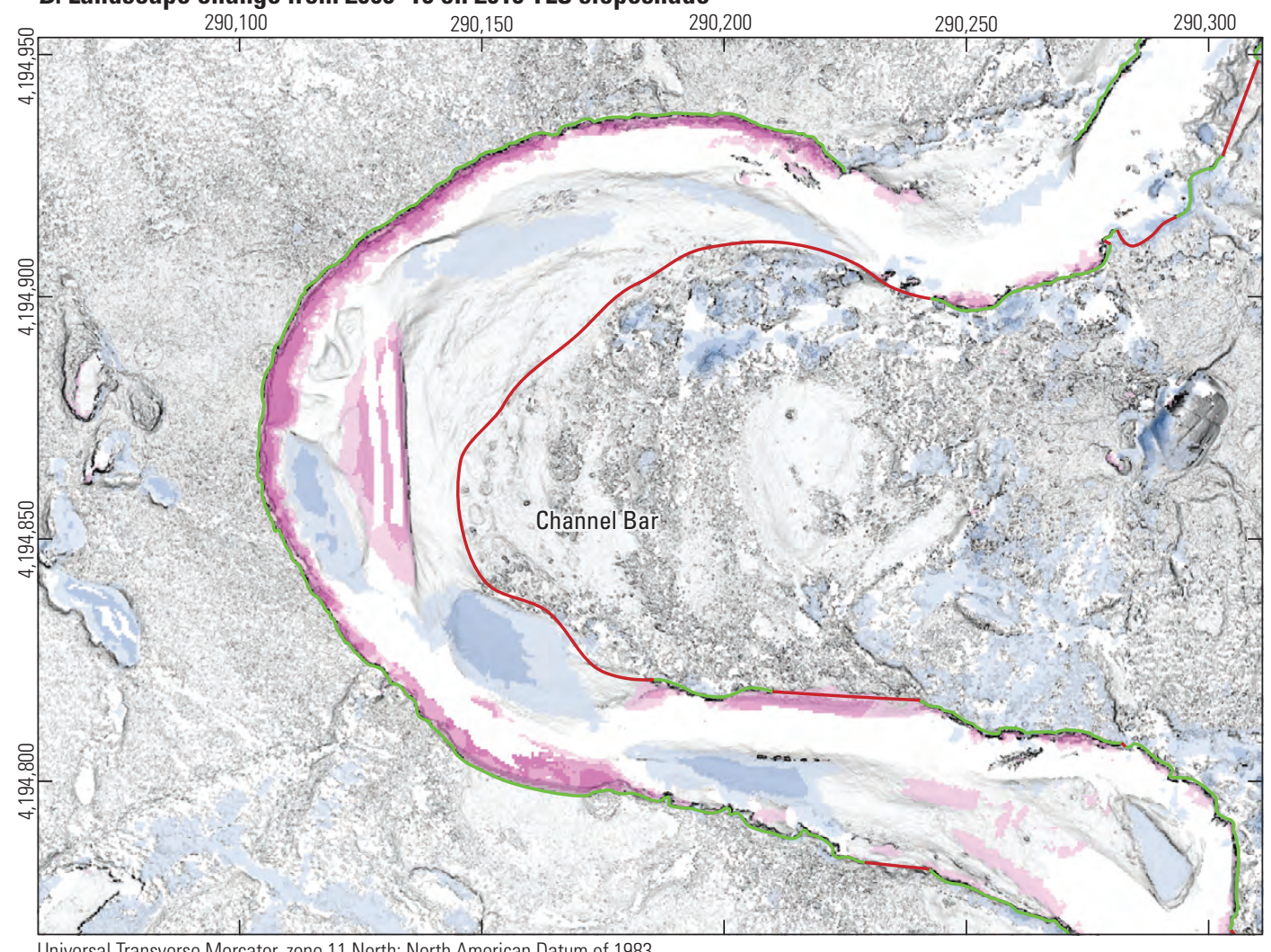

\section{EXPLANATION}

Elevation change, in meters

4 to 2

2 to 1

1 to 0.5

0.5 to 0.2

0.2 to -0.2

-0.2 to -0.5

-0.5 to -1

-1 to -2

-2 to -6

2016 streambanks

_- Indistinct/stable Steep/active

Figure 41. Lidar-derived maps showing location and classification of stream banks at erosion zone 12. $A, 2006$ airborne laser swath mapping (ALSM) bare-earth slopeshade with mapped streambanks. B, 2016 terrestrial laser scanning (TLS) bare-earth slopeshade. C, 2017 TLS bare-earth slopeshade. D, 2018 TLS bare-earth slopeshade. Colors indicate geomorphic change and lines are mapped streambanks. 
C. Landscape change from 2016-17 on 2017 TLS slopeshade

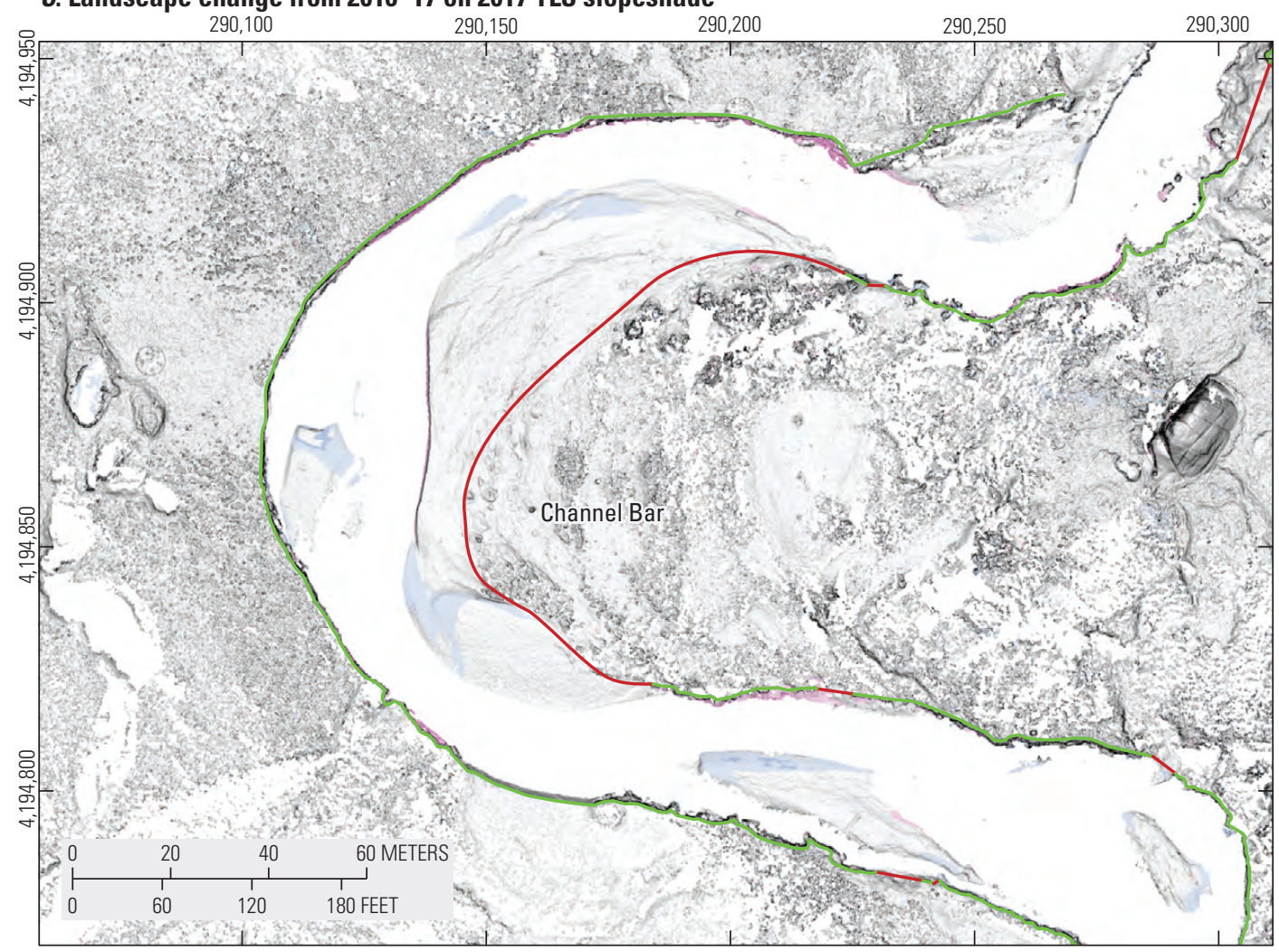

D. Landscape change from 2017-18 on 2018 TLS slopeshade

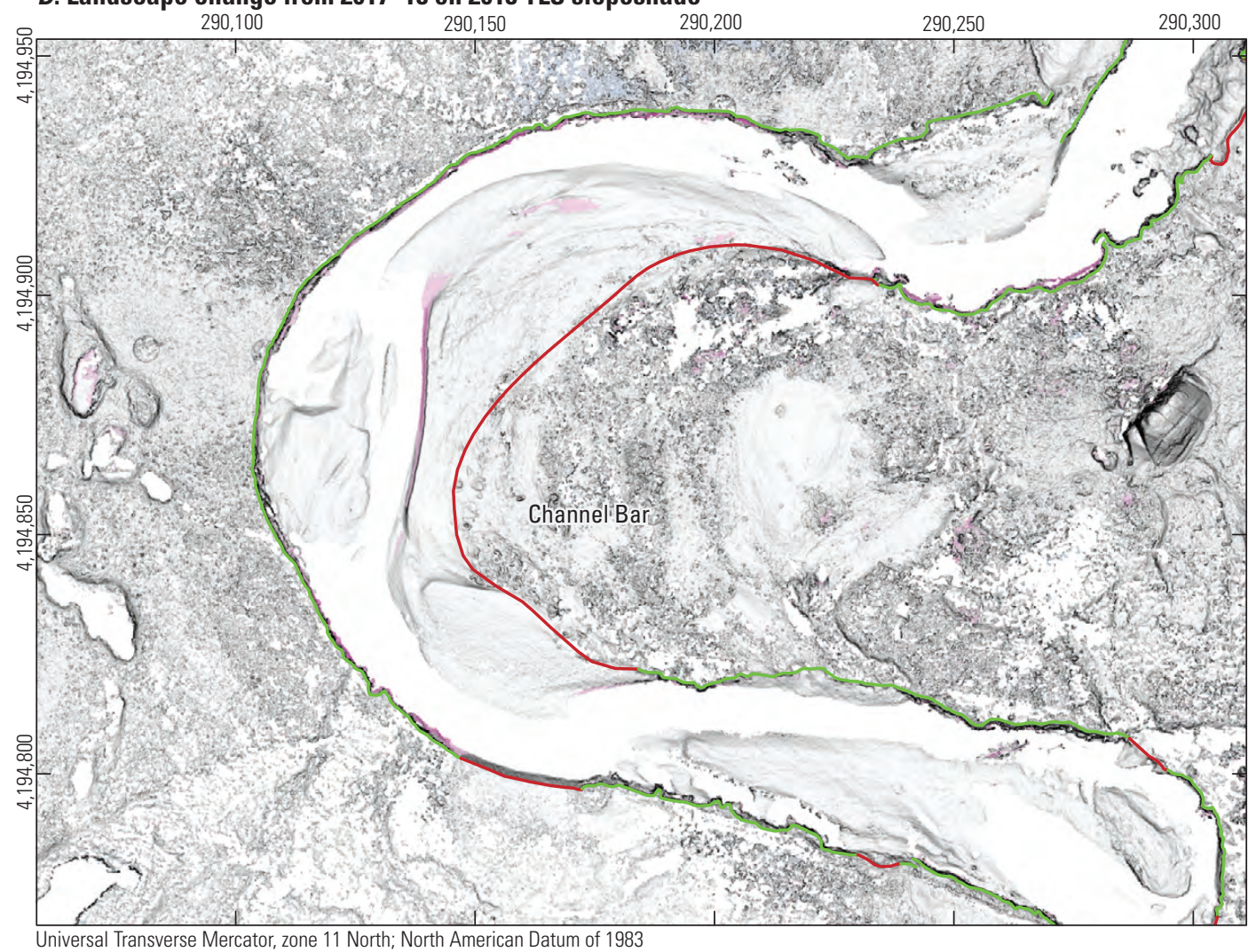

EXPLANATION

Elevation change, in meters

\begin{tabular}{|l|}
4 to 2 \\
2 to 1 \\
1 to 0.5 \\
0.5 to 0.2 \\
0.2 to -0.2 \\
-0.2 to -0.5 \\
-0.5 to -1 \\
-1 to -2 \\
-2 to -6
\end{tabular}

2017 streambanks

— Indistinct/stable Steep/active

\section{EXPLANATION}

Elevation change, in meters

4 to 2
2 to 1
1 to 0.5
0.5 to 0.2
0.2 to -0.2
-0.2 to -0.5
-0.5 to -1
-1 to -2
-2 to -6

2018 streambanks

—_ Indistinct/stable Steep/active

Figure 41.-Continued 
A. Vegetation canopy height from 2018 TLS data

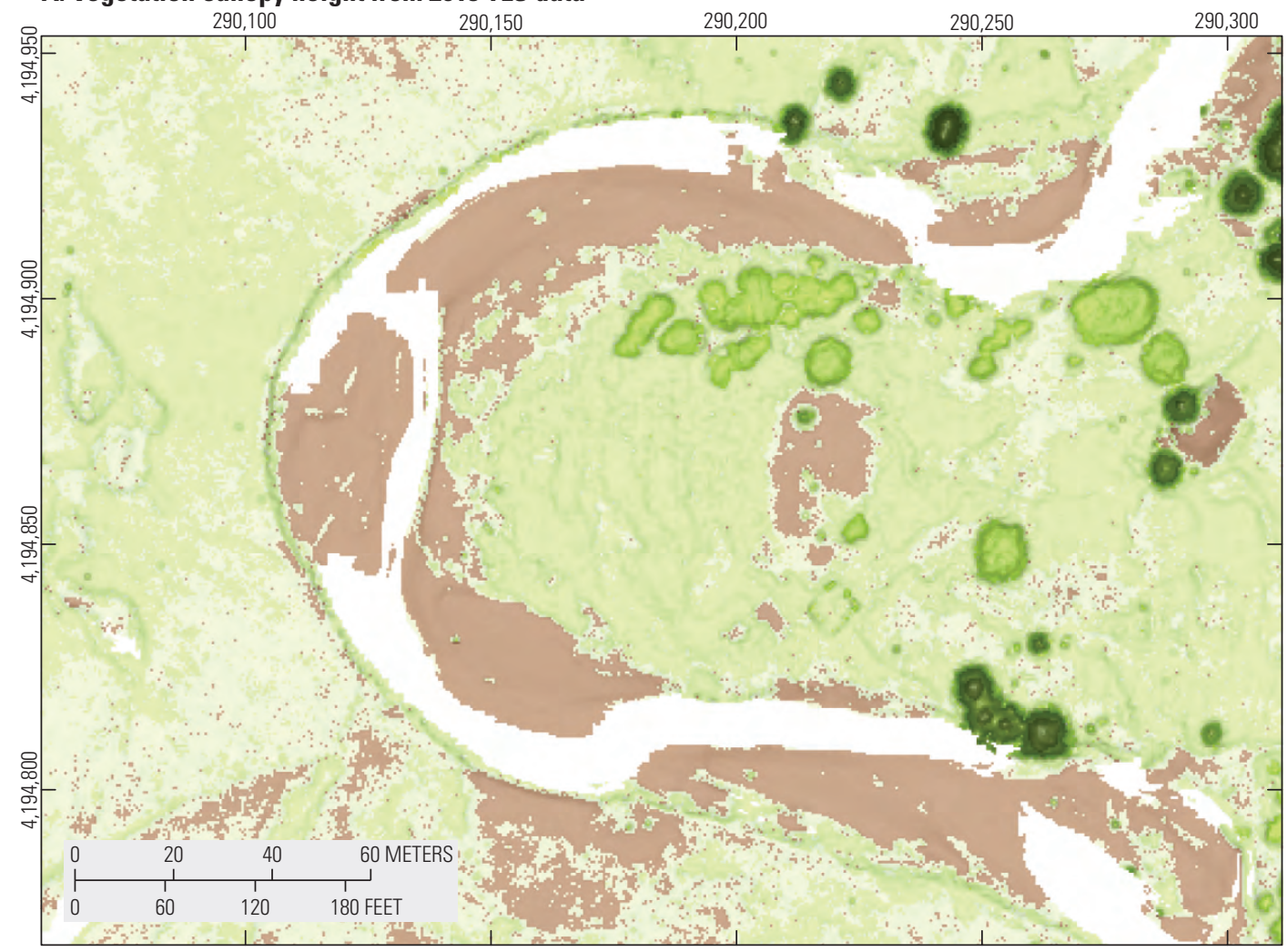

\section{EXPLANATION}

Canopy height, in meters

$<0.1$

0.1 to 0.25

0.25 to 1

1 to 2

2 to 4

4 to 10

10 to 20

20 to 30

30 to 50

B. Presence of streambank willows and other meadow vegetation from 2018 TLS data

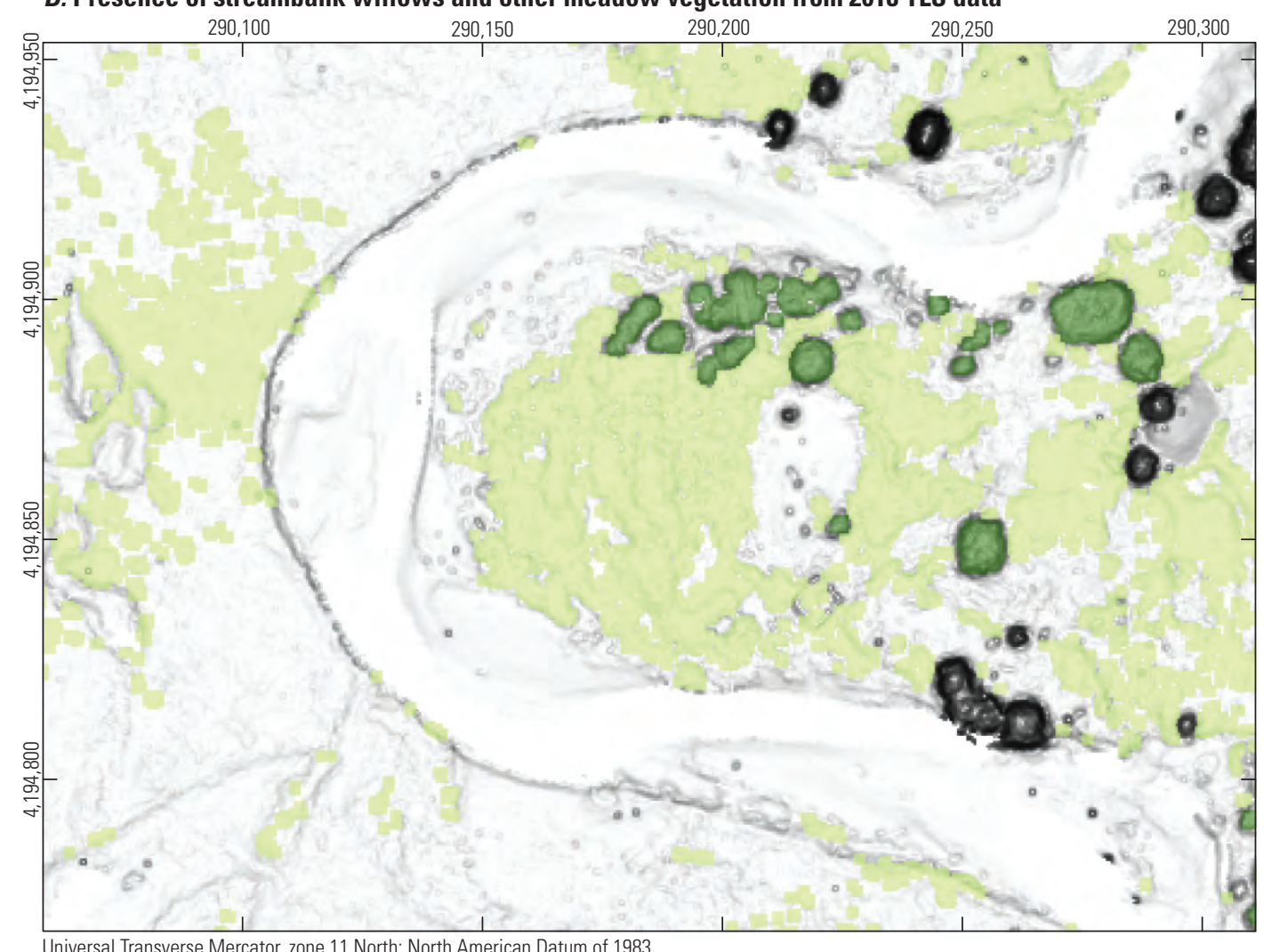

EXPLANATION

Canopy height, in meters

0.25 to 1 -Short vegetation

1 to 4-Mostly willows

Universal Transverse Mercator, zone 11 North; North American Datum of 1983

Figure 42. Lidar-derived maps of vegetation at erosion zone 12. Data are from 2018 terrestrial laser scanning (TLS). $A$, shows a semitransparent canopy-height model over full-feature slopeshade. $B$, shows a map of vegetation most likely to be streambank willows and meadow vegetation. 

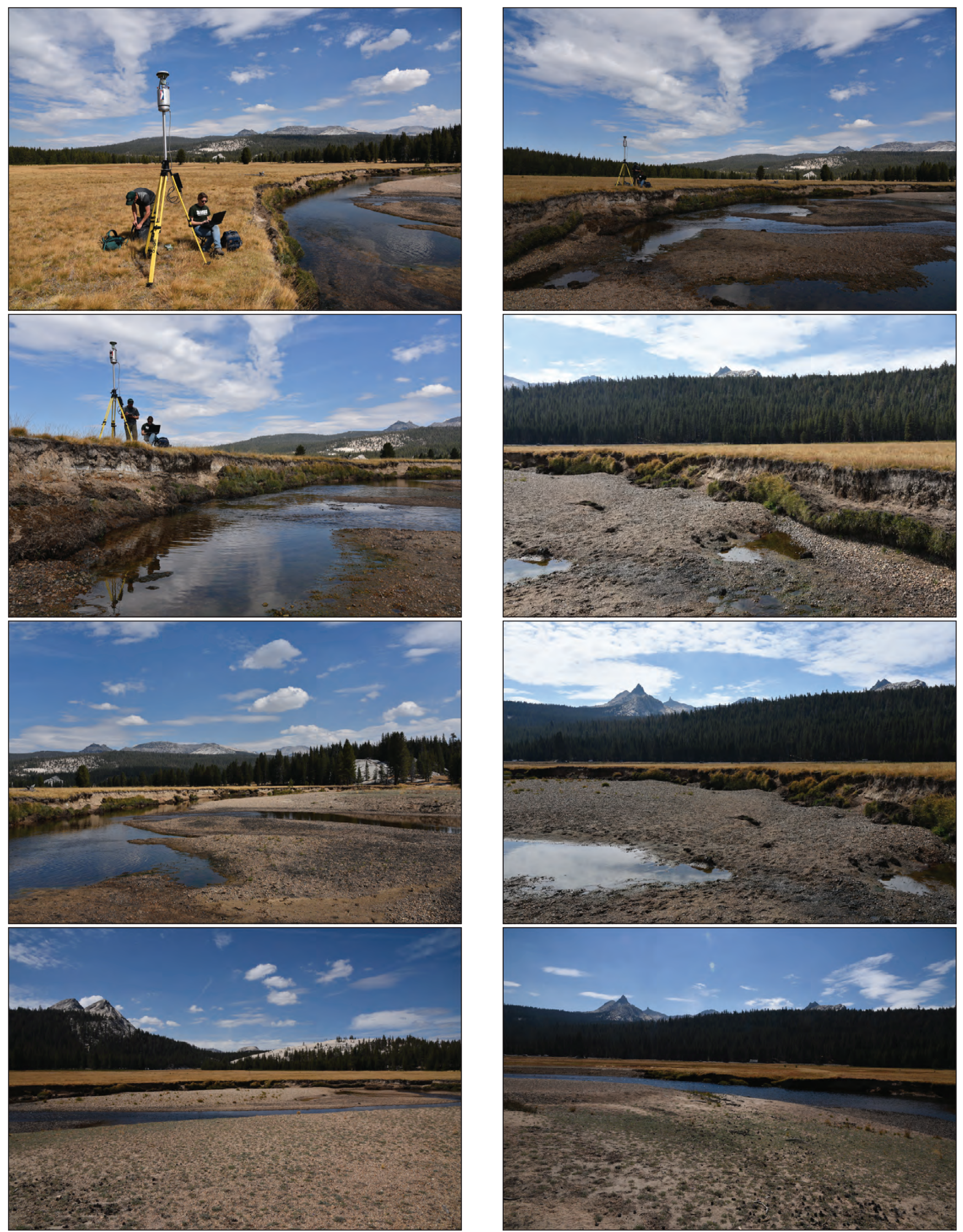

Figure 43. U.S. Geological Survey photographs of erosion zone 12, taken in 2016. 
Table 14. Estimates of erosion and deposition at erosion zone 12 along Tuolumne River.

[---, no data; DEM, digital elevation model; DoD, DEMs of difference; $\mathrm{m}$, meter; $\mathrm{m}^{2}$, square meter; $\mathrm{m}^{3}$, cubic meter]

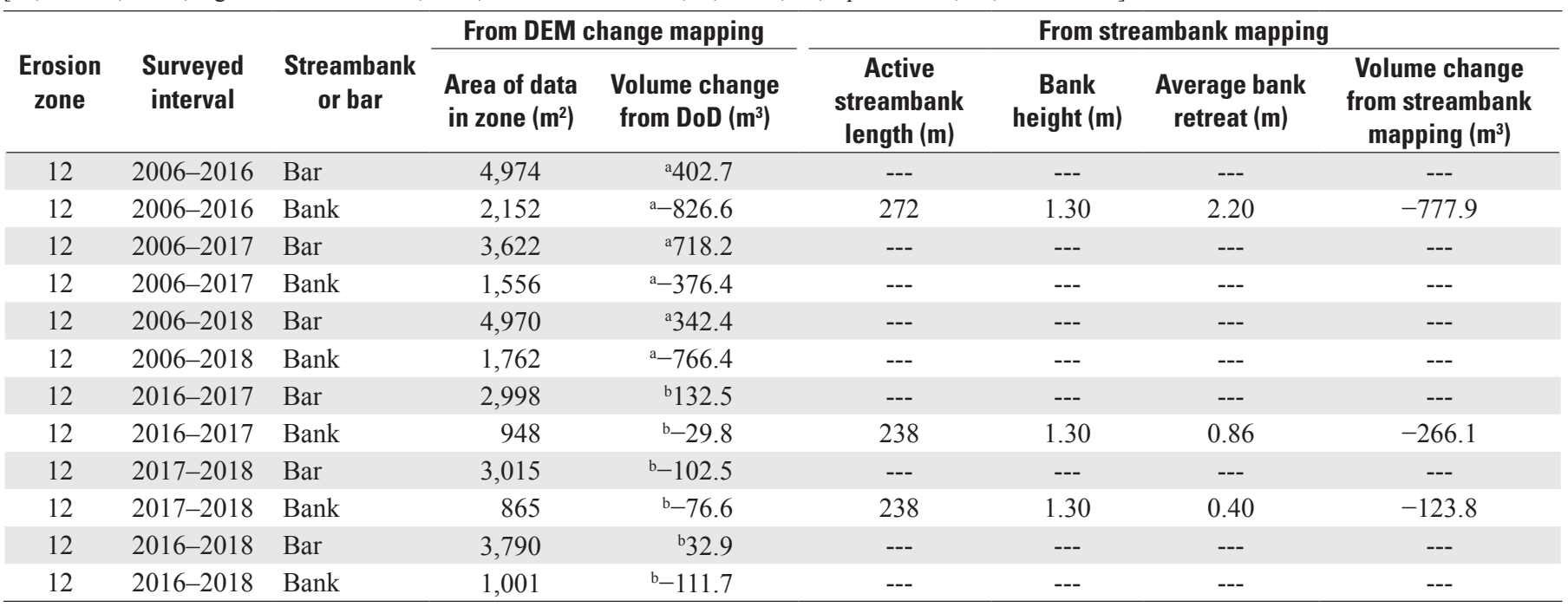

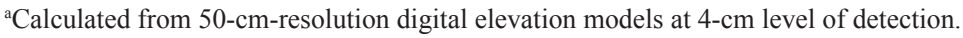

${ }^{\mathrm{b}}$ Calculated from 10-cm-resolution digital elevation models at 2-cm level of detection. 


\section{Erosion Zone 13}

Erosion zones 13-15 were not surveyed in 2016. Erosion zone 13 is at a gentle bend in the Tuolumne River. It is opposite of a large point bar (fig. 44). The streambank is eroding a grasscovered surface underlain by soil and fluvial sediment (figs. 45 and 46). Over a length of about $111 \mathrm{~m}$, the streambank retreated an average of $3.4 \mathrm{~m}$ from 2006 to 2017 (table 15), though much of the material was stored as large slump blocks (fig. 46). Erosion removed between about 193 and $491 \mathrm{~m}^{3}$ of sediment, though the higher number is clearly an overestimate because of the slump block material that was not completely removed. From 2017 to 2018 the streambank was stable, through the DoD derived estimate of about $16 \mathrm{~m}^{3}$ of streambank erosion indicate some slump block material was removed during this time. From 2006 to 2017 , about $178 \mathrm{~m}^{3}$ of material was deposited on the point bar, and about $4 \mathrm{~m}^{3}$ of this was eroded from the point bar in 2018.

Over the full study period 2006-2018, about $13 \mathrm{~m}^{3}$ was deposited on the point bar and between about 310 and $491 \mathrm{~m}^{3}$ of sediment was eroded from the streambank. This apparent inconsistency between the 2006-2017 deposition and the 2006-2018 deposition is explained by the erosion of the point bar below the water level at the time of the 2017 survey, which was revealed by the lowerwater 2018 survey.

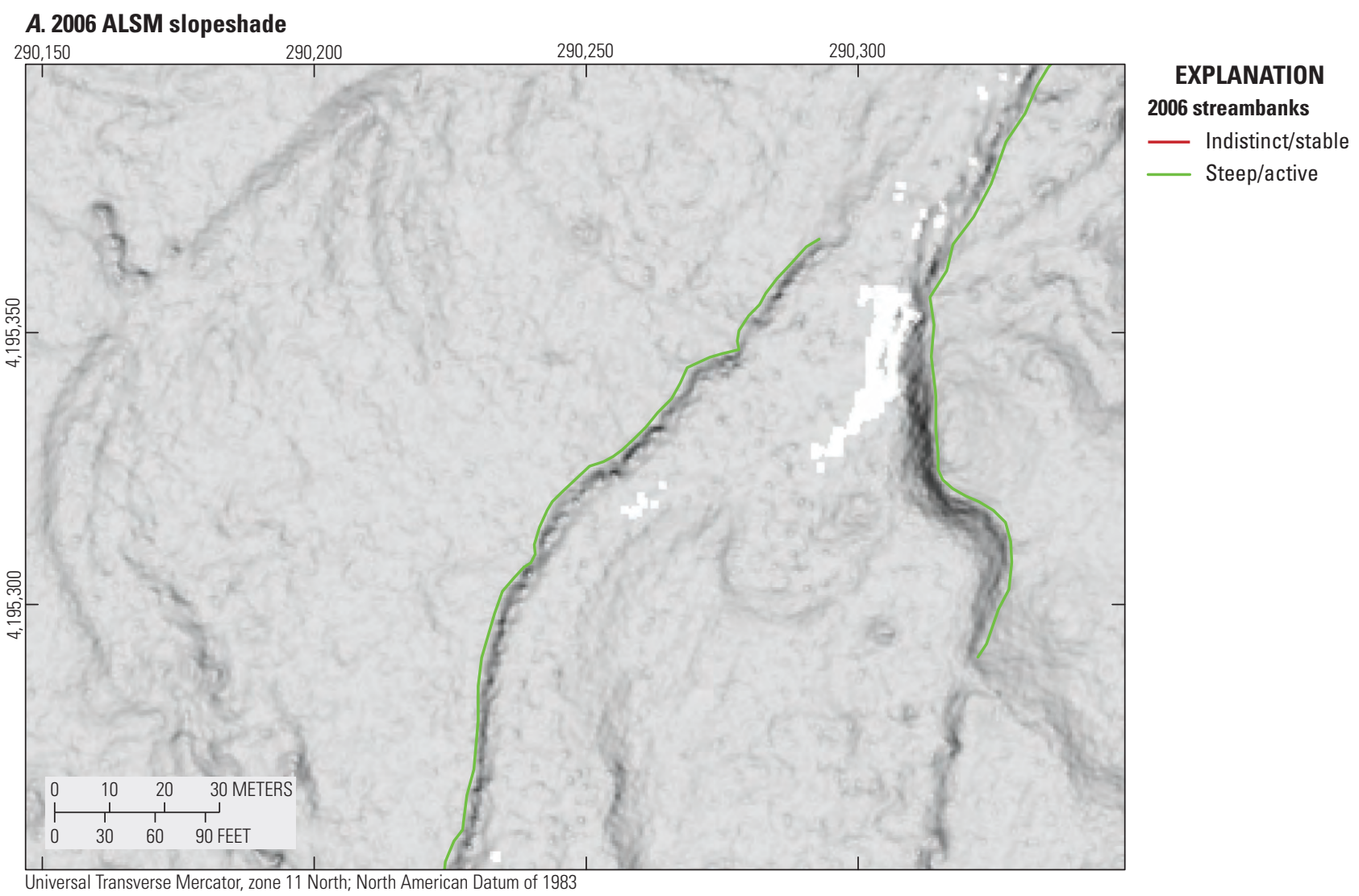

Figure 44. Lidar-derived maps showing location and classification of stream banks in erosion zone 13. $A$, Map is 2006 airborne laser swath mapping (ALSM) bare-earth slopeshade with mapped streambanks. B, 2017 terrestrial laser scanning (TLS) bare-earth slopeshade. C, 2018 TLS bare-earth slopeshade. Colors indicate geomorphic change and lines are mapped streambanks. 
B. Landscape change from 2006-17 on 2017 TLS slopeshade

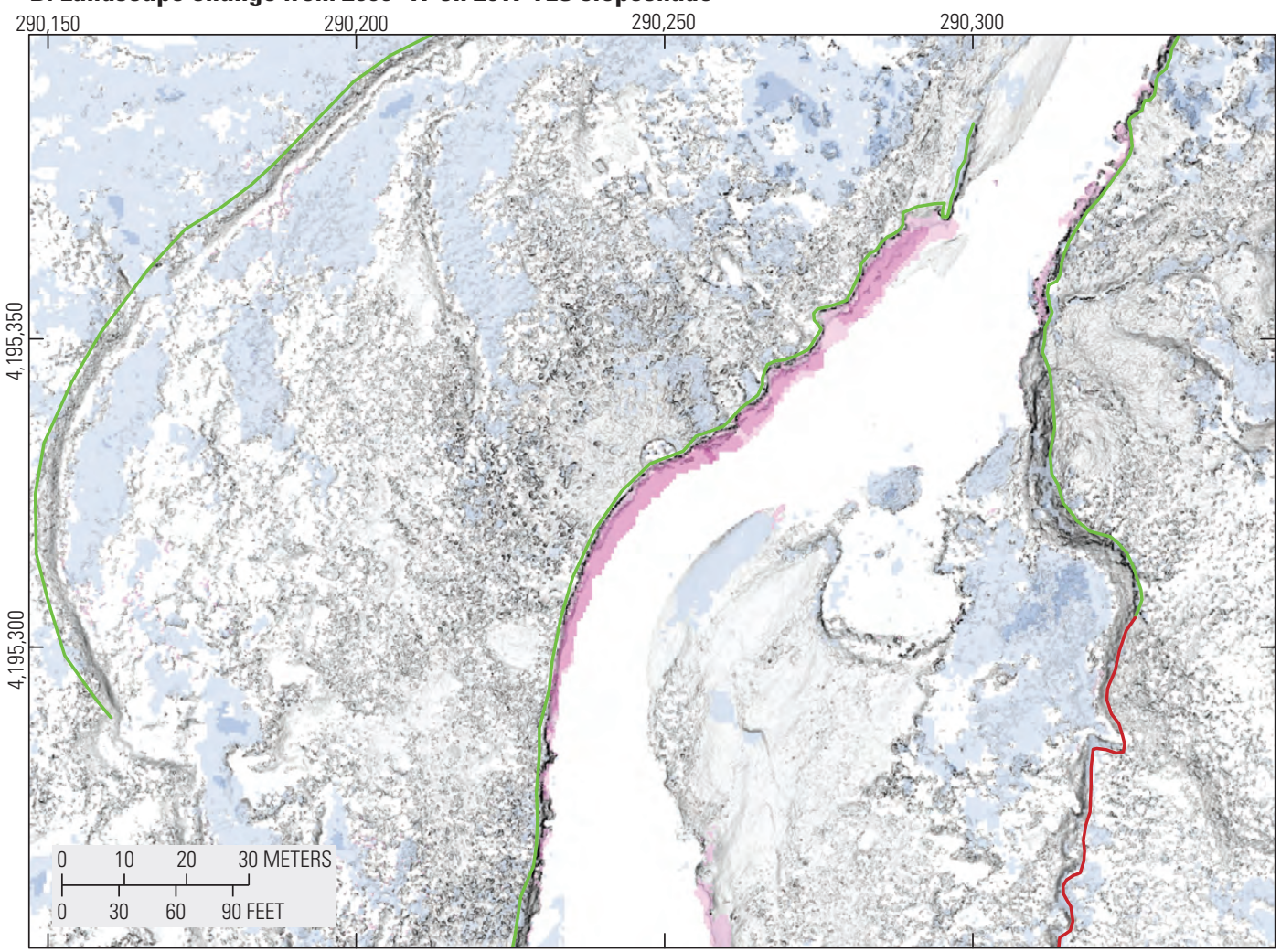

EXPLANATION

Elevation change, in meters

Elevation change, in mers

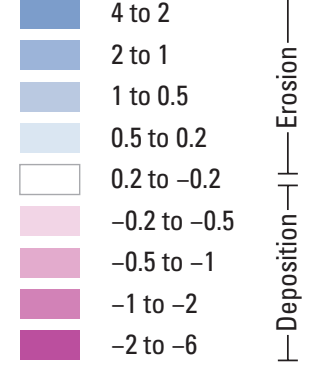

2017 streambanks

__ Indistinct/stable

Steep/active

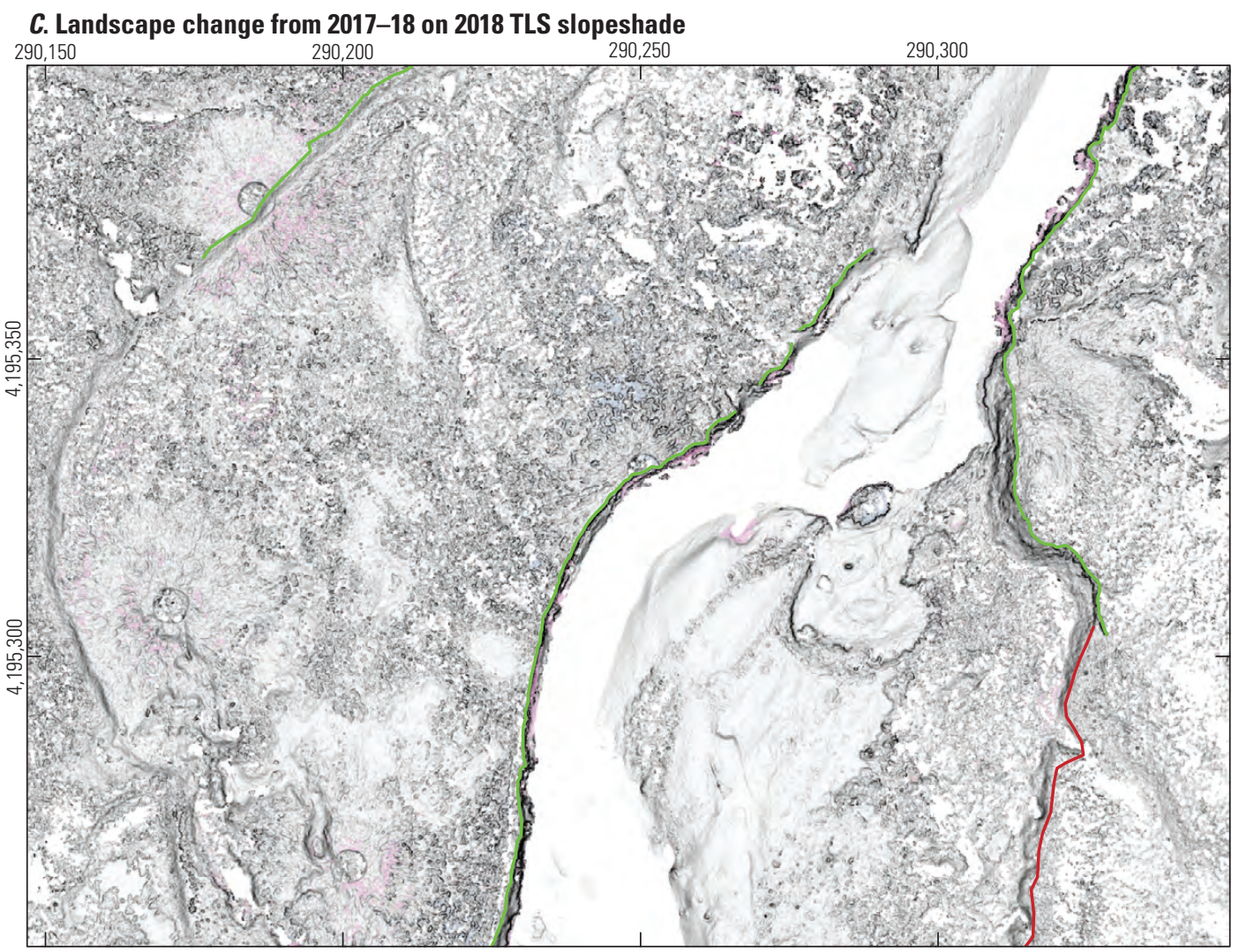

EXPLANATION

Elevation change, in meters

4 to 2

4 to 2
2 to 1
1 to 0.5
0.5 to 0.2
0.2 to -0.2
-0.2 to -0.5
-0.5 to -1
-1 to -2
-2 to -6

2018 streambanks

_ Indistinct/stable

- Steep/active

Figure 44.-Continued 
A. Vegetation canopy height from 2018 TLS data

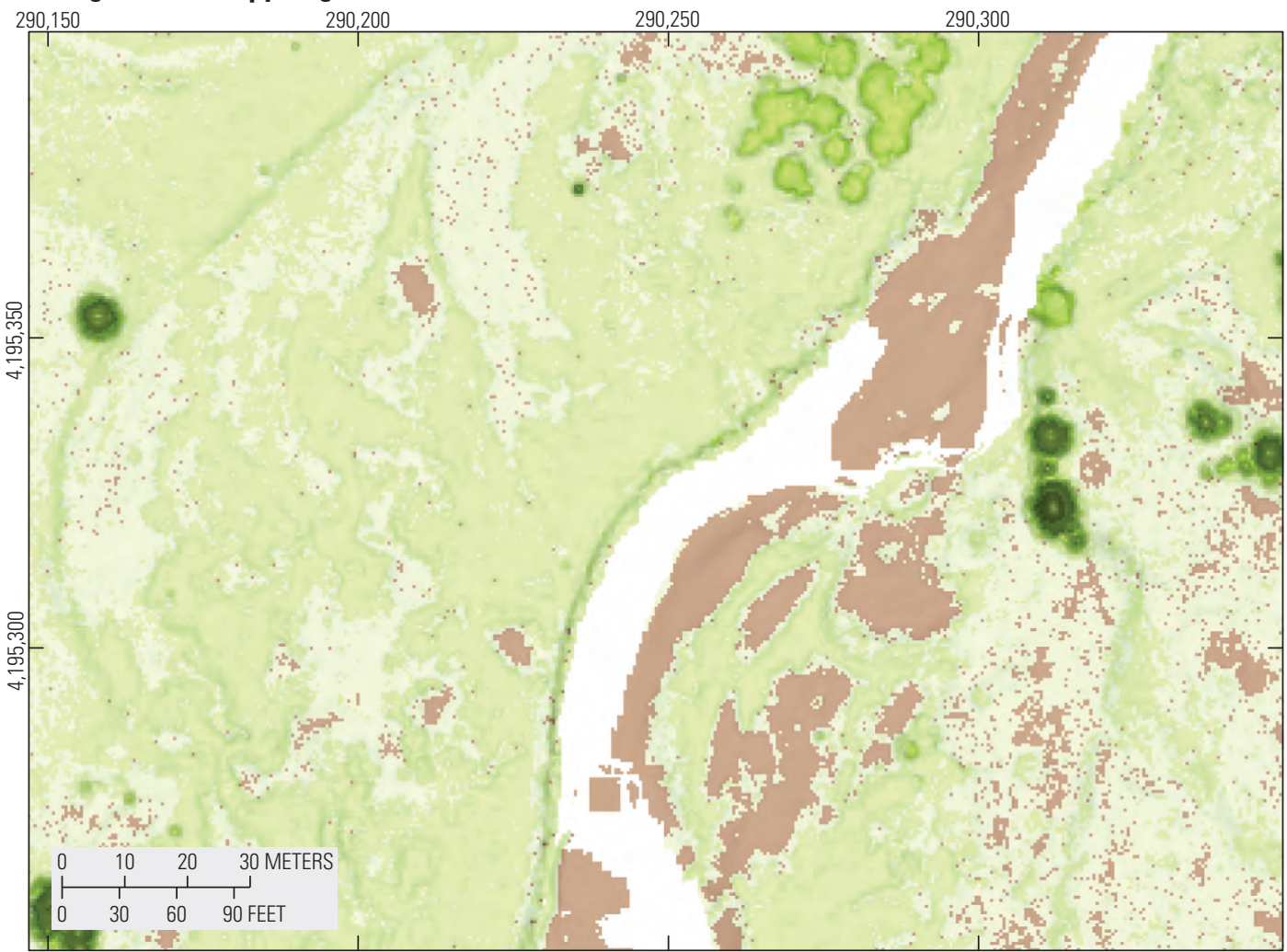

$B$. Presence of streambank willows and other meadow vegetation from 2018 TLS data

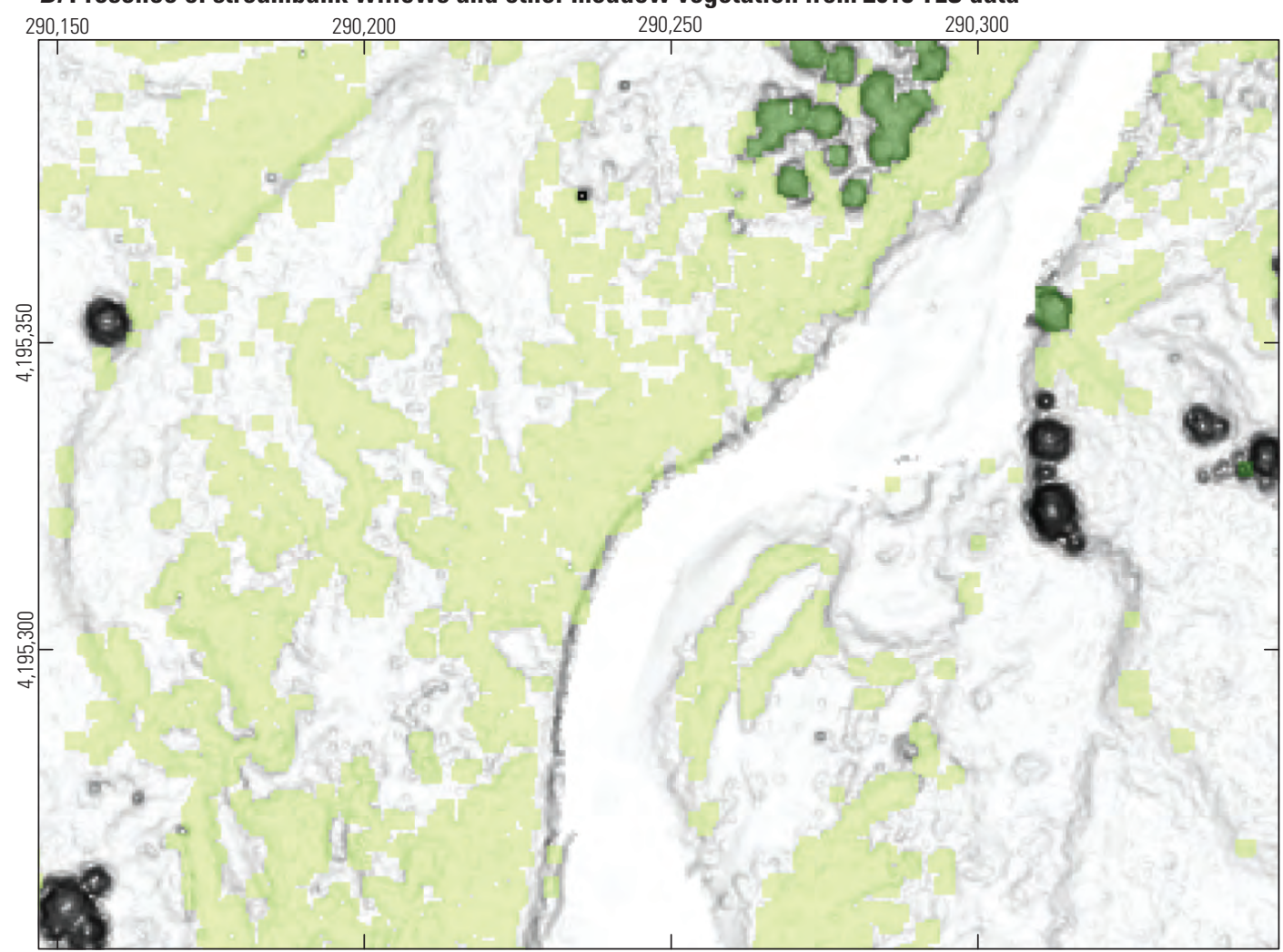

Universal Transverse Mercator, zone 11 North; North American Datum of 1983

Figure 45. Lidar-derived maps of vegetation at erosion zone 13. Data are from 2018 terrestrial laser scanning (TLS). $A$, shows a semitransparent canopy-height model over full-feature slopeshade. $B$, shows a map of vegetation most likely to be streambank willows and meadow vegetation.

\section{EXPLANATION}

Canopy height, in meters $<0.1$ 0.1 to 0.25 0.25 to 1

1 to 2 2 to 4 4 to 10 10 to 20 20 to 30

30 to 50

\section{EXPLANATION}

Canopy height, in meters 0.25 to 1 -Short vegetation 1 to 4 -Mostly willows 


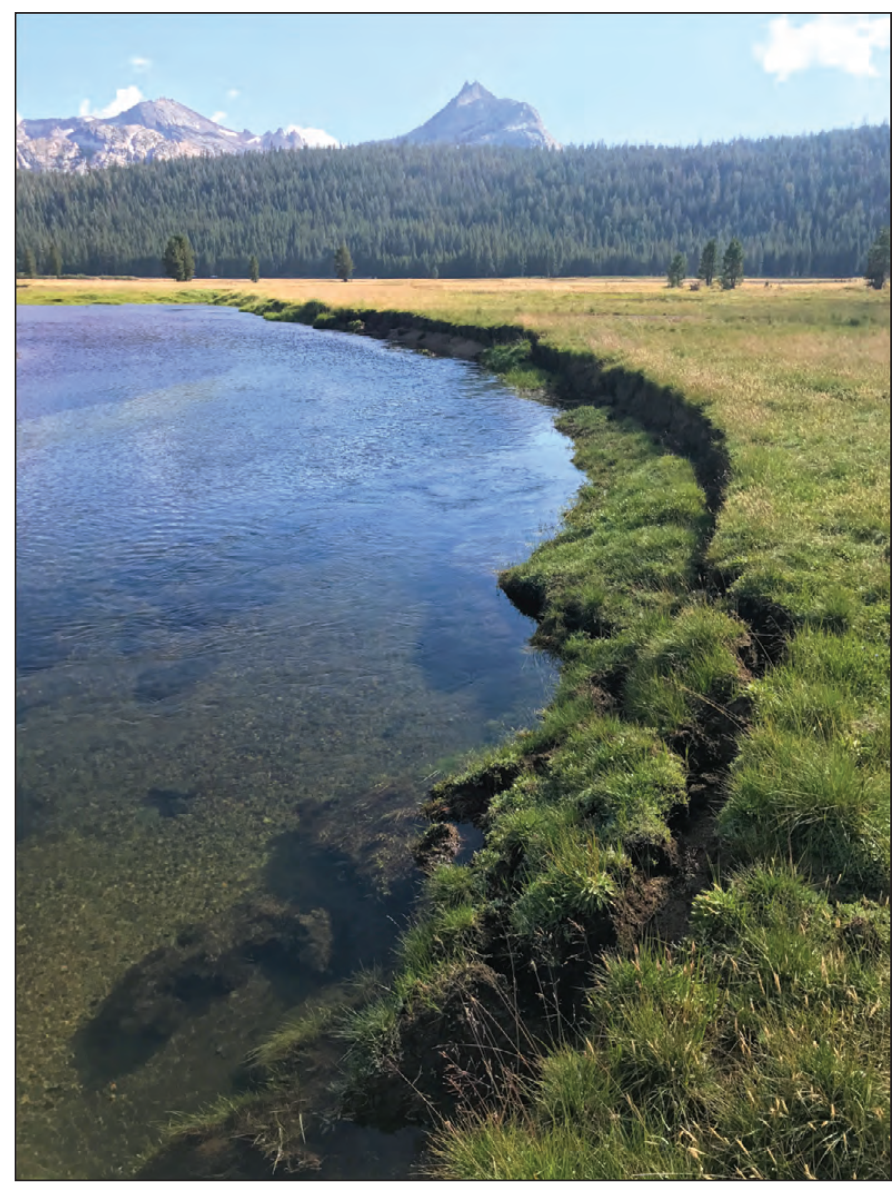

Figure 46. U.S. Geological Survey photographs of erosion zone 13, taken in 2017.

Table 15. Estimates of erosion and deposition at erosion zone 13 along Tuolumne River.

[---, no data; DEM, digital elevation model; DoD, DEMs of difference; m, meter; $\mathrm{m}^{2}$, square meter; $\mathrm{m}^{3}$, cubic meter]

\begin{tabular}{|c|c|c|c|c|c|c|c|c|}
\hline \multirow[b]{2}{*}{$\begin{array}{l}\text { Erosion } \\
\text { zone }\end{array}$} & \multirow[b]{2}{*}{$\begin{array}{l}\text { Surveyed } \\
\text { interval }\end{array}$} & \multirow[b]{2}{*}{$\begin{array}{c}\text { Streambank } \\
\text { or bar }\end{array}$} & \multicolumn{2}{|c|}{ From DEM change mapping } & \multicolumn{4}{|c|}{ From streambank mapping } \\
\hline & & & $\begin{array}{l}\text { Area of data } \\
\text { in zone }\left(\mathrm{m}^{2}\right)\end{array}$ & $\begin{array}{c}\text { Volume change } \\
\text { from } D_{0} D\left(\mathrm{~m}^{3}\right)\end{array}$ & $\begin{array}{c}\text { Active } \\
\text { streambank } \\
\text { length }(\mathbf{m})\end{array}$ & $\begin{array}{c}\text { Bank } \\
\text { height }(\mathrm{m})\end{array}$ & $\begin{array}{c}\text { Average bank } \\
\text { retreat }(\mathrm{m})\end{array}$ & $\begin{array}{c}\text { Volume change } \\
\text { from streambank } \\
\text { mapping }\left(\mathrm{m}^{3}\right)\end{array}$ \\
\hline 13 & 2006-2016 & Bank & --- & --- & --- & --- & --- & --- \\
\hline 13 & 2006-2017 & Bar & 2,323 & ${ }^{\mathrm{a}} 178.1$ & --- & --- & --- & --- \\
\hline 13 & 2006-2018 & Bank & 1,031 & a-309.6 & --- & --- & --- & --- \\
\hline 13 & 2016-2017 & Bar & --- & --- & --- & --- & --- & --- \\
\hline 13 & 2016-2017 & Bank & --- & --- & --- & --- & --- & --- \\
\hline 13 & 2017-2018 & Bar & 1,723 & $\mathrm{~b}-3.7$ & --- & --- & --- & --- \\
\hline 13 & $2017-2018$ & Bank & 620 & b-15.9 & 60 & 1.30 & 0 & 0.0 \\
\hline
\end{tabular}

${ }^{a}$ Calculated from 50-cm-resolution digital elevation models at 4-cm level of detection.

${ }^{\mathrm{b}}$ Calculated from 10-cm-resolution digital elevation models at 2-cm level of detection. 


\section{Erosion Zone 14}

The retreating streambank in erosion zone 14 is a relatively short $(27 \mathrm{~m})$ portion of a long streambank at a horseshoe bend in the Tuolumne River where it turns from northward to westward (fig. 47). A pre-2016 slumped block of streambank material just upstream of the small active portion of the streambank was stable from 2006 to 2018 and hosts at least two small willow plants. The short portion of eroding streambank is retreating into a grass covered surface underlain by fluvial sediment and a root network apparently from nearby pine trees (figs. 48 and 49). From 2006 to 2017 the streambank retreated an average of about $0.08 \mathrm{~m}$ causing between about 3 and $15 \mathrm{~m}^{3}$ of erosion. In 2018 the streambank retreated another about $0.21 \mathrm{~m}$, causing another about $6-8 \mathrm{~m}^{3}$ of erosion (table 16). Between 2006 and 2018, sediment deposition on the point bar far exceeded erosion on the streambank, about $324 \mathrm{~m}^{3}$ of sediment was deposited on this large point bar. Though not included in this erosion zone analysis, the next channel/point bar downstream was also highly depositional during this time period and contributed substantially to the full channel area deposition.

\section{A. 2006 ALSM slopeshade}

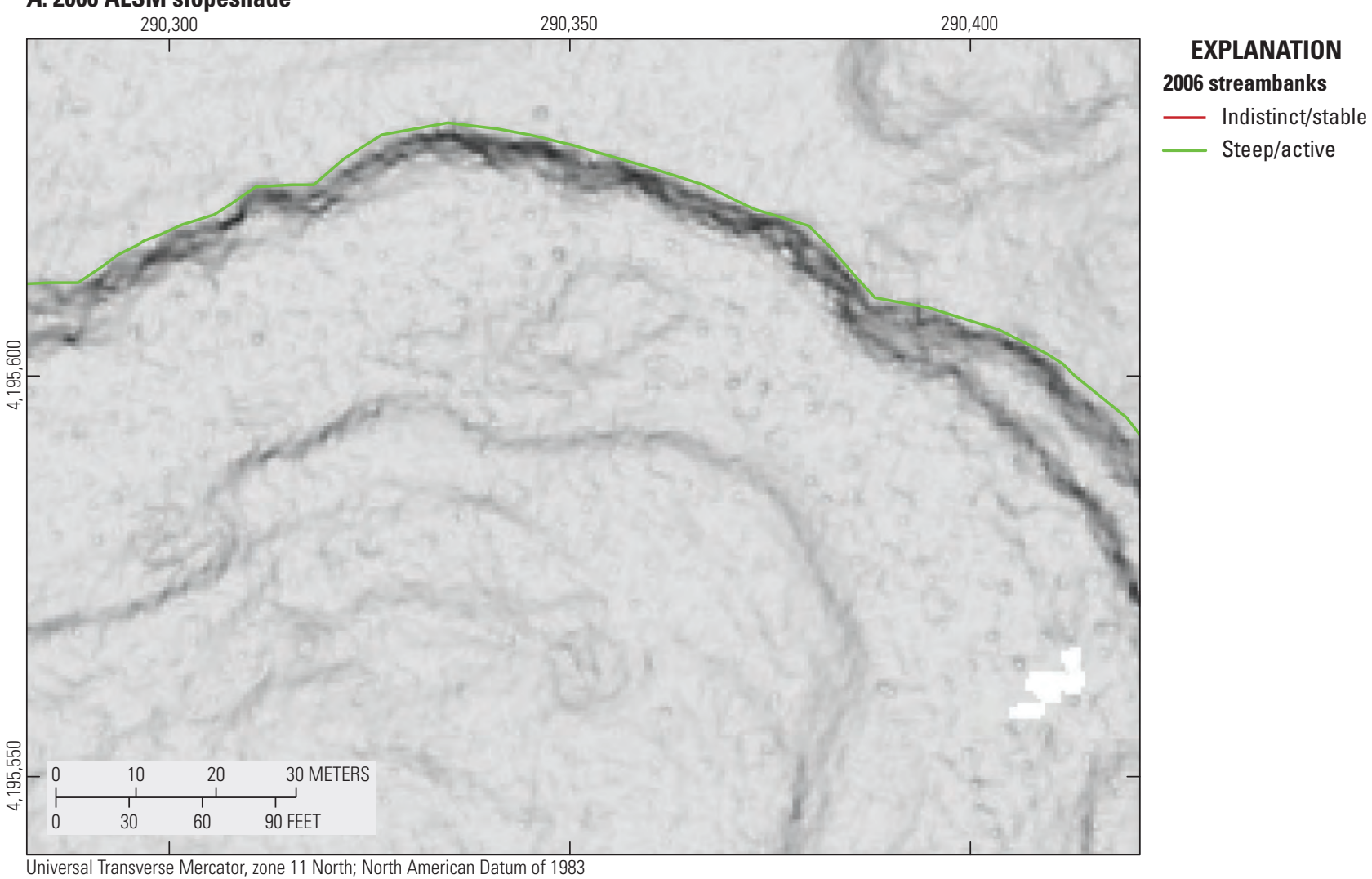

Figure 47. Lidar-derived maps showing classification of stream banks at erosion zone 14. A, 2006 airborne laser swath mapping (ALSM) bare-earth slopeshade with mapped streambanks. B, 2017 terrestrial laser scanning (TLS) bare-earth slopeshade. C, 2018 TLS bare-earth slopeshade. Colors indicate geomorphic change and lines are mapped streambanks. 


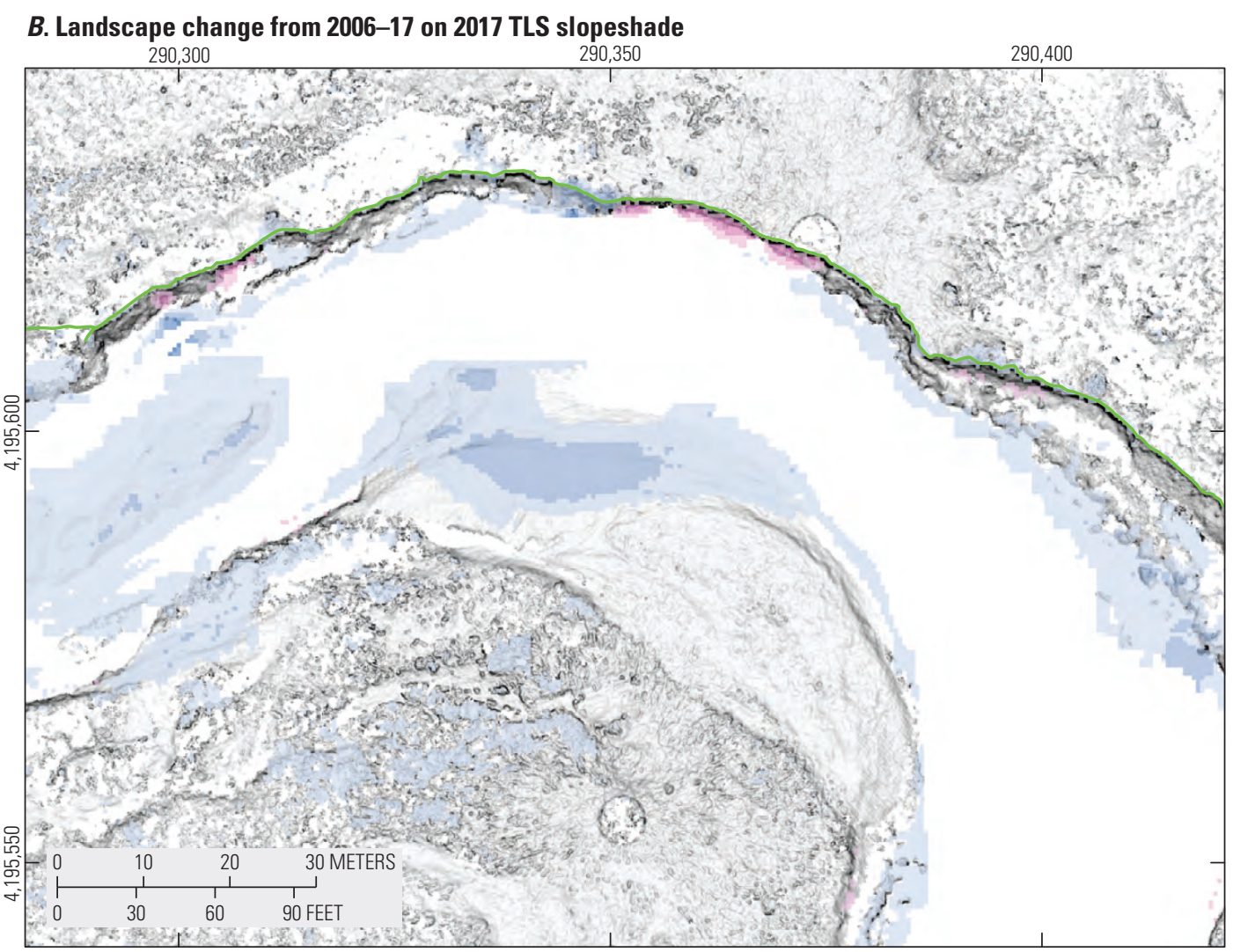

\section{EXPLANATION}

Elevation change, in meters

4 to 2

2 to 1

1 to 0.5

0.5 to 0.2

0.2 to $-0.2-1$

0.2 to $-0.2 \quad$

-0.2 to -0.5

-0.5 to -1

-1 to -2

-2 to $-6 \perp$

2017 streambanks

_ Indistinct/stable

- Steep/active

\section{Landscape change from 2017-18 on 2018 TLS slopeshade}

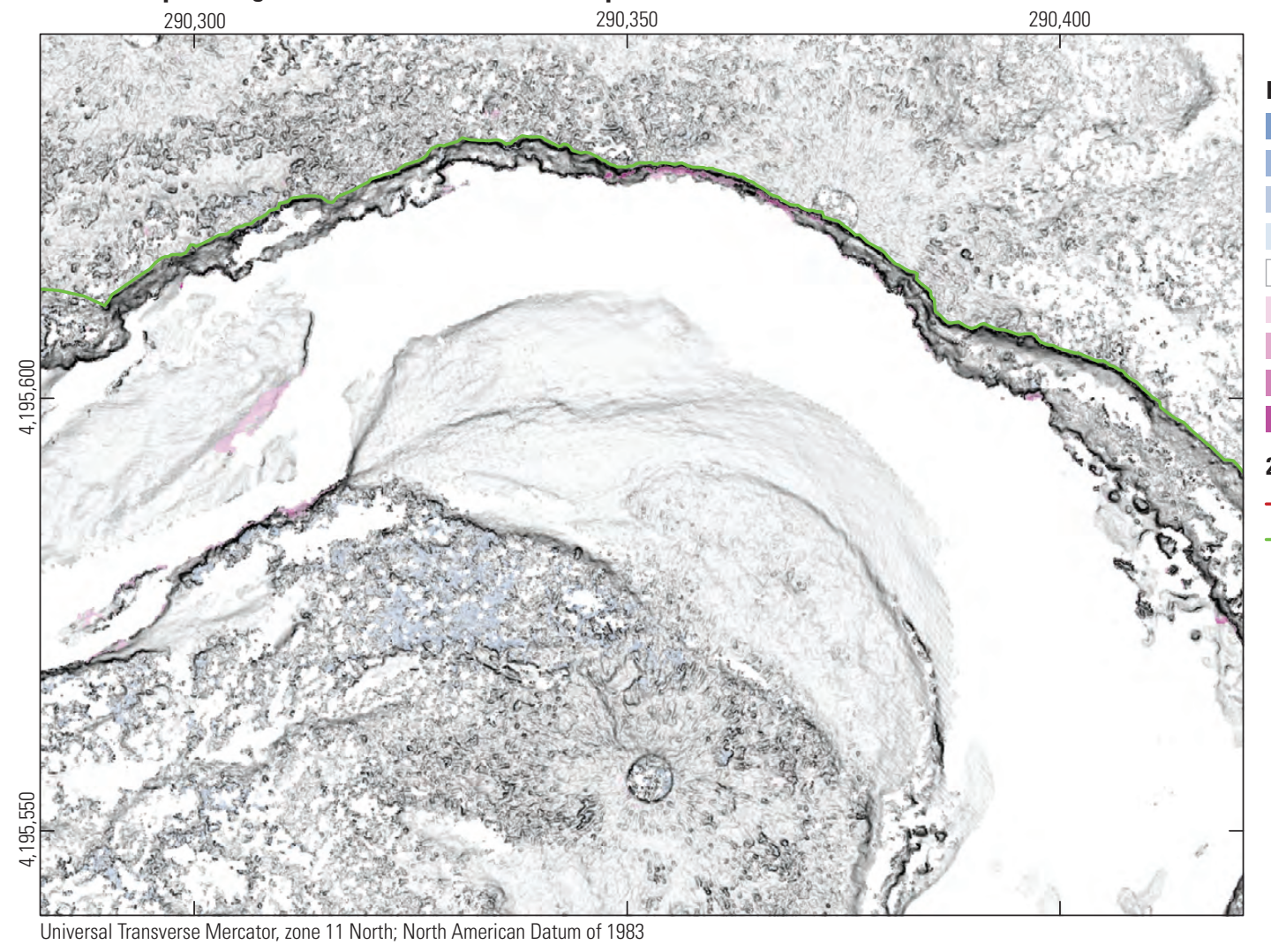

\section{EXPLANATION}

Elevation change, in meters

\begin{tabular}{|c|}
\hline 4 to 2 \\
\hline 2 to 1 \\
\hline 1 to 0.5 \\
\hline 0.5 to 0.2 \\
\hline 0.2 to -0.2 \\
\hline-0.2 to -0.5 \\
\hline-0.5 to -1 \\
\hline-1 to -2 \\
\hline-2 to -6 \\
\hline
\end{tabular}

2018 streambanks

Indistinct/stable Steep/active

Figure 47.-Continued 


\section{A. Vegetation canopy height from 2018 TLS data}

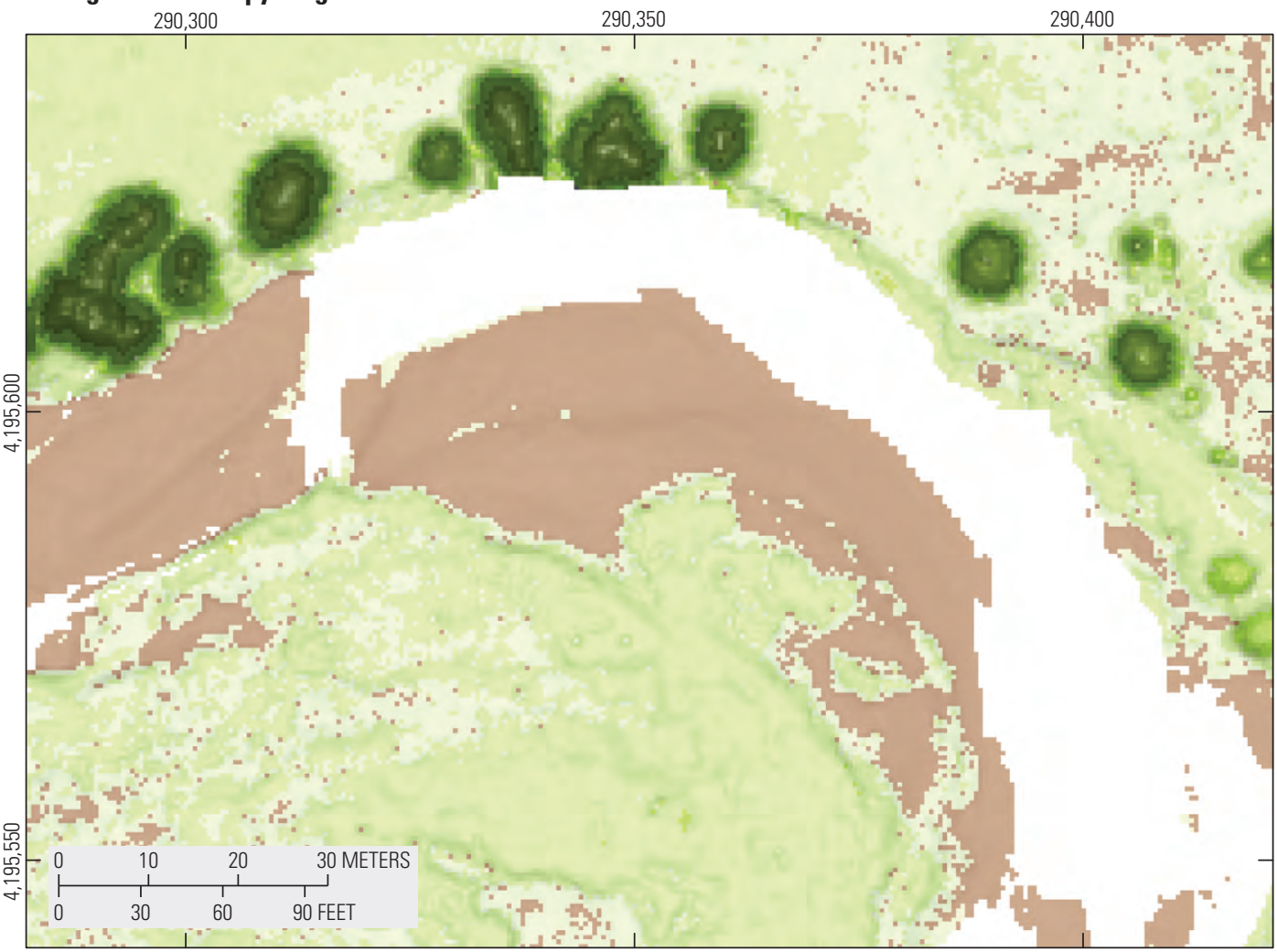

B. Presence of streambank willows and other meadow vegetation from 2018 TLS data

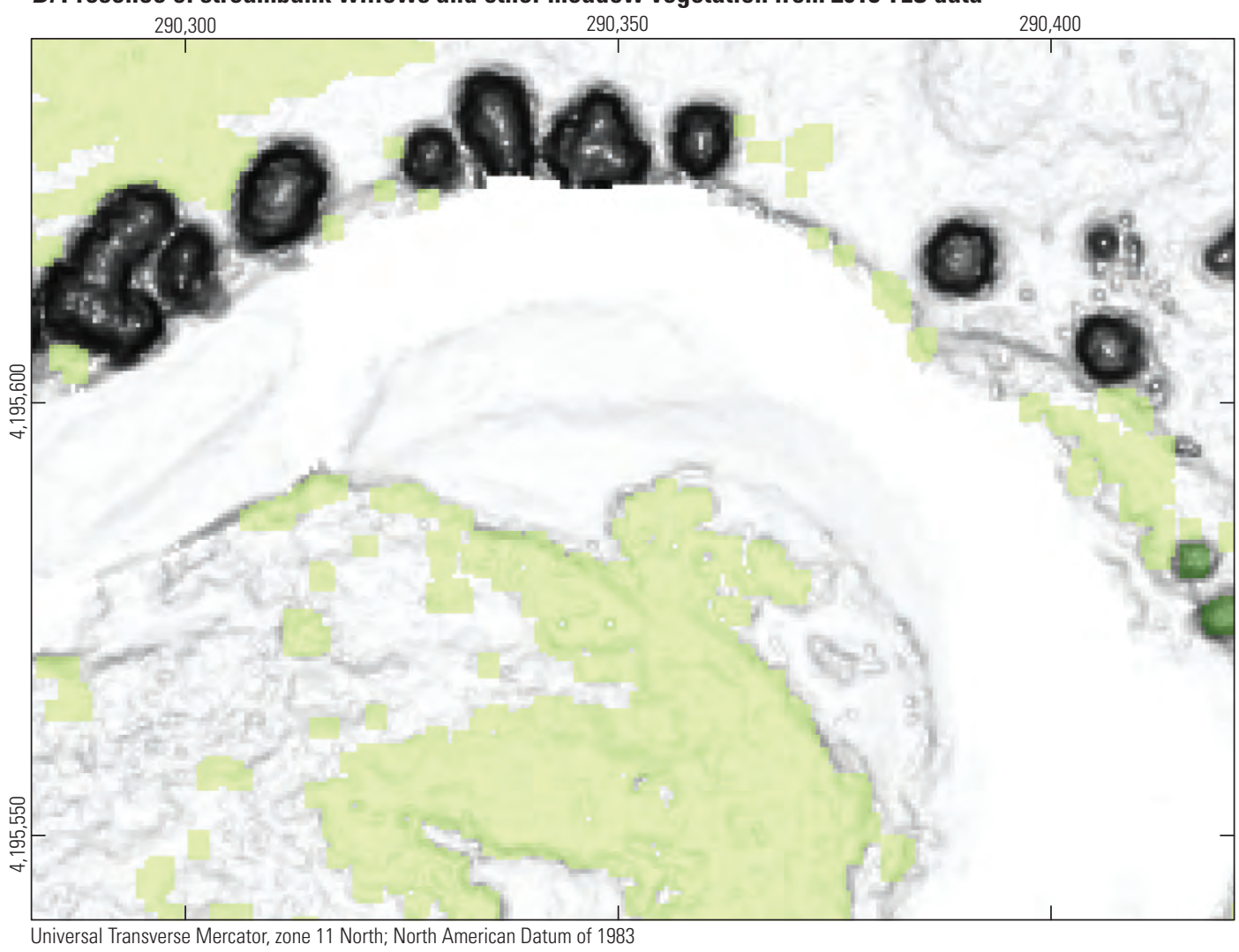

EXPLANATION

Canopy height, in meters $<0.1$

0.1 to 0.25

0.25 to 1

1 to 2

2 to 4

4 to 10

10 to 20

20 to 30

30 to 50

\section{EXPLANATION}

Canopy height, in meters

0.25 to 1 -Short vegetation

1 to 4 -Mostly willows

Figure 48. Lidar-derived maps of vegetation at erosion zone 14. Data are from 2018 terrestrial laser scanning (TLS). A, shows a semitransparent canopy-height model over full-feature slopeshade. B, shows a map of vegetation most likely to be streambank willows and meadow vegetation. 

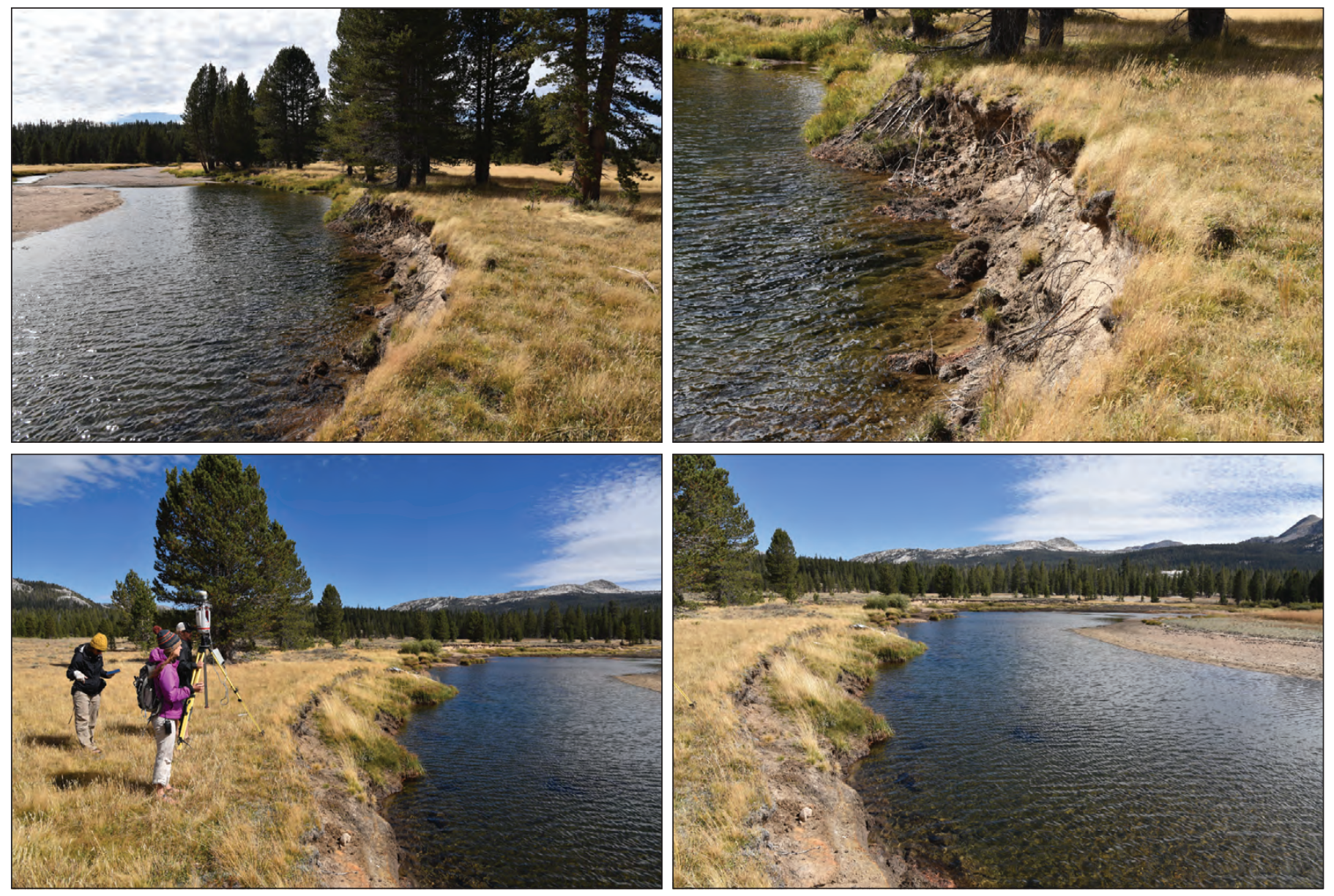

Figure 49. U.S. Geological Survey photographs of erosion zone 14, taken in 2018.

Table 16. Estimates of erosion and deposition at erosion zone 14 along Tuolumne River.

[---, no data; DEM, digital elevation model; DoD, DEMs of difference; $\mathrm{m}$, meter; $\mathrm{m}^{2}$, square meter; $\mathrm{m}^{3}$, cubic meter]

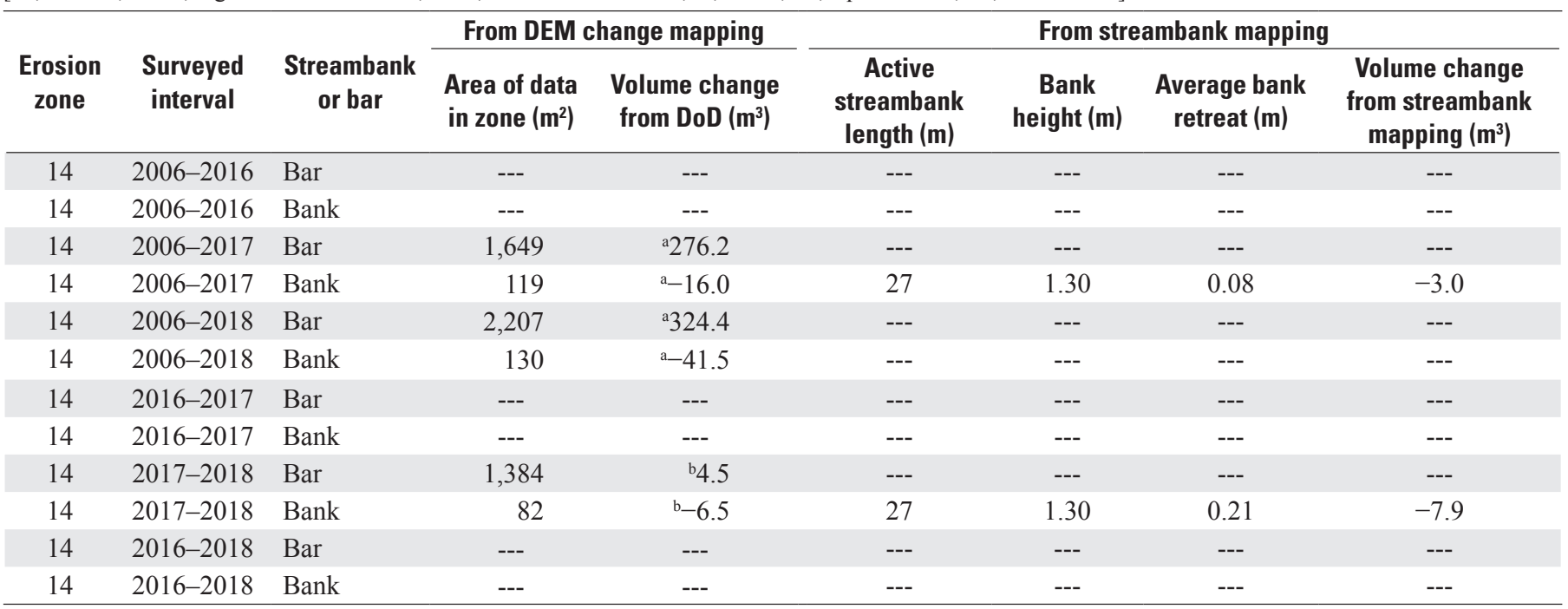

${ }^{a}$ Calculated from 50-cm-resolution digital elevation models at 4-cm level of detection.

${ }^{\mathrm{b}}$ Calculated from $10-\mathrm{cm}-$ resolution digital elevation models at $2-\mathrm{cm}$ level of detection. 


\section{Erosion Zone 15}

Erosion zone 15 sits at the last bend in the Tuolumne River before it exits Tuolumne Meadows (figs. 50). The streambank is eroding a surface covered by grass and short vegetation. The vegetation cover was all less than $1 \mathrm{~m}$ tall when surveyed but has more diversity in structure than vegetation above eroding streambanks elsewhere in the Meadows, much of it very thick and grassy (figs. 51 and 52). The surface has more microtopography than most other areas of erosion; this may indicate some heterogeneity of the underlying soil and sediment. A pine-covered slope is just over $30 \mathrm{~m}$ from the streambank (fig. 52). A large, unvegetated point bar is opposite of the eroding streambank and some channel bars are in the stream channel between the point bar and the streambank, some of which are in contact with the streambank.

Limited erosion occurred in this zone. From 2006 to 2017 $44 \mathrm{~m}$ of streambank retreated an average of about $0.12 \mathrm{~m}$. From 2017 to 2018 the streambank retreated about $0.05 \mathrm{~m}$ over a length of $20 \mathrm{~m}$. From 2006 to 2018 the DoD analysis indicated that about $252 \mathrm{~m}^{3}$ of sediment was eroded. Most of this appears to have been eroded from the channel bars and edge of the point bar. The DoD from 2006 to 2017 does not indicate this erosion, indicating much of it occurred below the 2017 water level and was only exposed in the lower water conditions in 2018. The 2006 ALSM is challenging to interpret in this area and may not be reliable, even a few anomalous laser data returns in shallow water in the 2006 data could complicate this analysis. The streambank eroded between about 9 and $59 \mathrm{~m}^{3}$ of sediment from 2006 to 2018 .

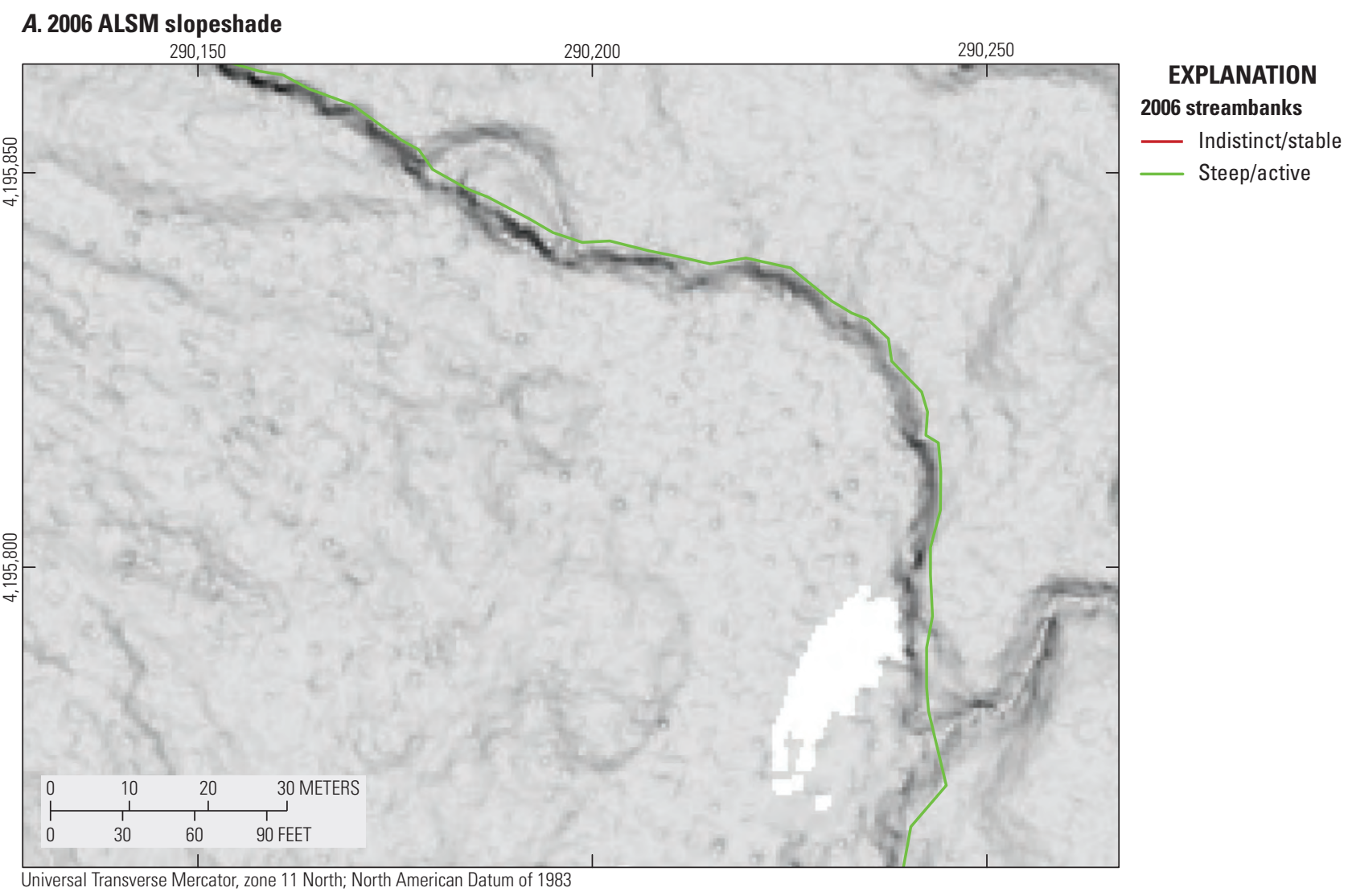

Figure 50. Lidar-derived maps showing classification of stream banks at erosion zone 15. A, 2006 airborne laser swath mapping (ALSM) bare-earth slopeshade with mapped streambanks. B, 2017 terrestrial laser scanning (TLS) bare-earth slopeshade. C, 2018 TLS bare-earth slopeshade. Colors indicate geomorphic change and lines are mapped streambanks. 


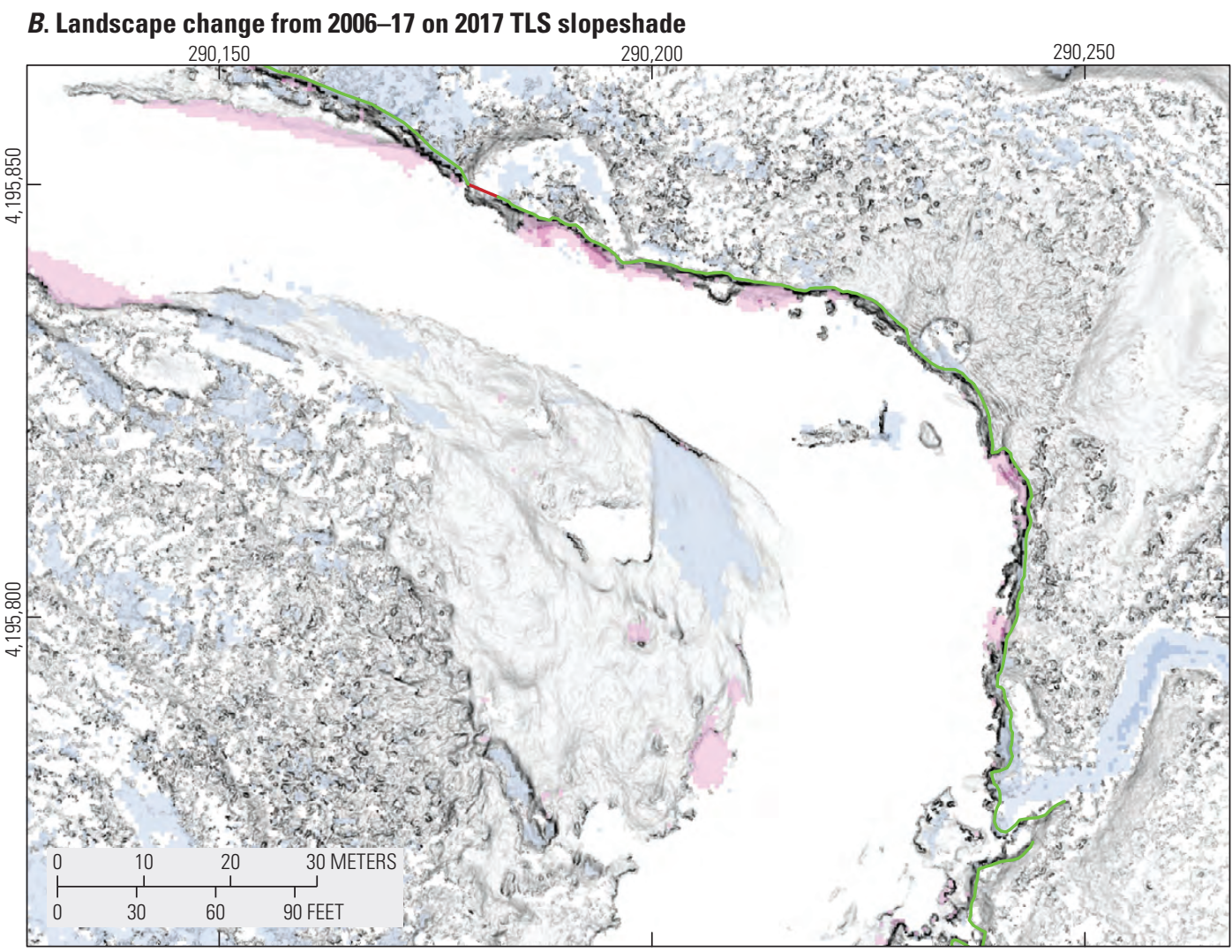

\section{EXPLANATION}

Elevation change, in meters

\begin{tabular}{|l|}
\hline 4 to 2 \\
2 to 1 \\
1 to 0.5 \\
0.5 to 0.2 \\
0.2 to -0.2 \\
-0.2 to -0.5 \\
-0.5 to -1 \\
-1 to -2 \\
-2 to -6 \\
\hline
\end{tabular}

\section{7 streambanks}

__ Indistinct/stable Steep/active

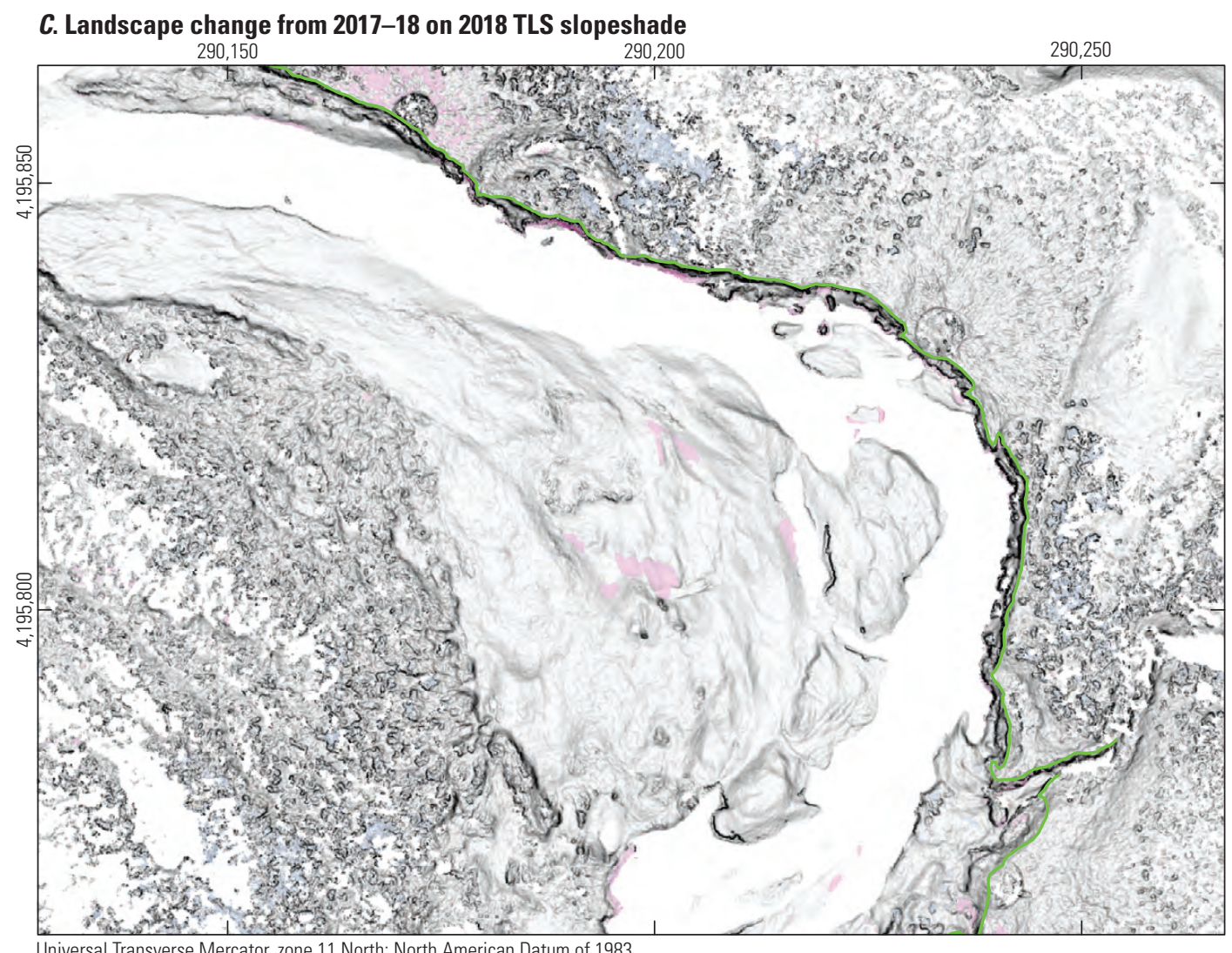

\section{EXPLANATION}

Elevation change, in meters

\begin{tabular}{|l|}
\hline 4 to 2 \\
2 to 1 \\
1 to 0.5 \\
0.5 to 0.2 \\
0.2 to -0.2 \\
-0.2 to -0.5 \\
-0.5 to -1 \\
-1 to -2 \\
-2 to -6 \\
\hline
\end{tabular}

2018 streambanks

_ Indistinct/stable Steep/active

Figure 50.-Continued 
A. Vegetation canopy height from 2018 TLS data

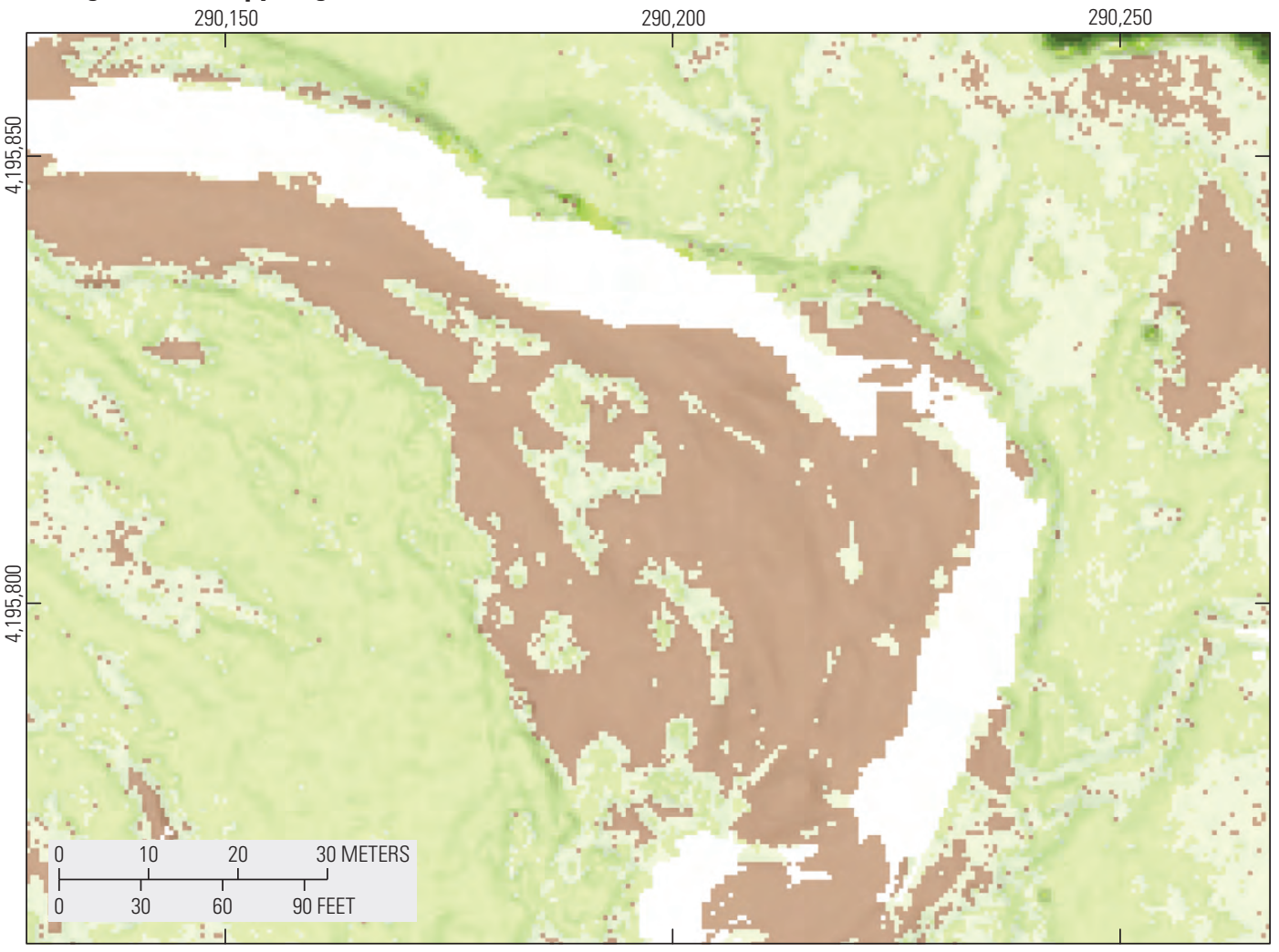

\section{EXPLANATION}

Canopy height, in meters

$<0.1$

0.1 to 0.25

0.25 to 1

1 to 2

2 to 4

4 to 10

10 to 20

20 to 30

30 to 50

\section{B. Presence of streambank willows and other meadow vegetation from 2018 TLS data}

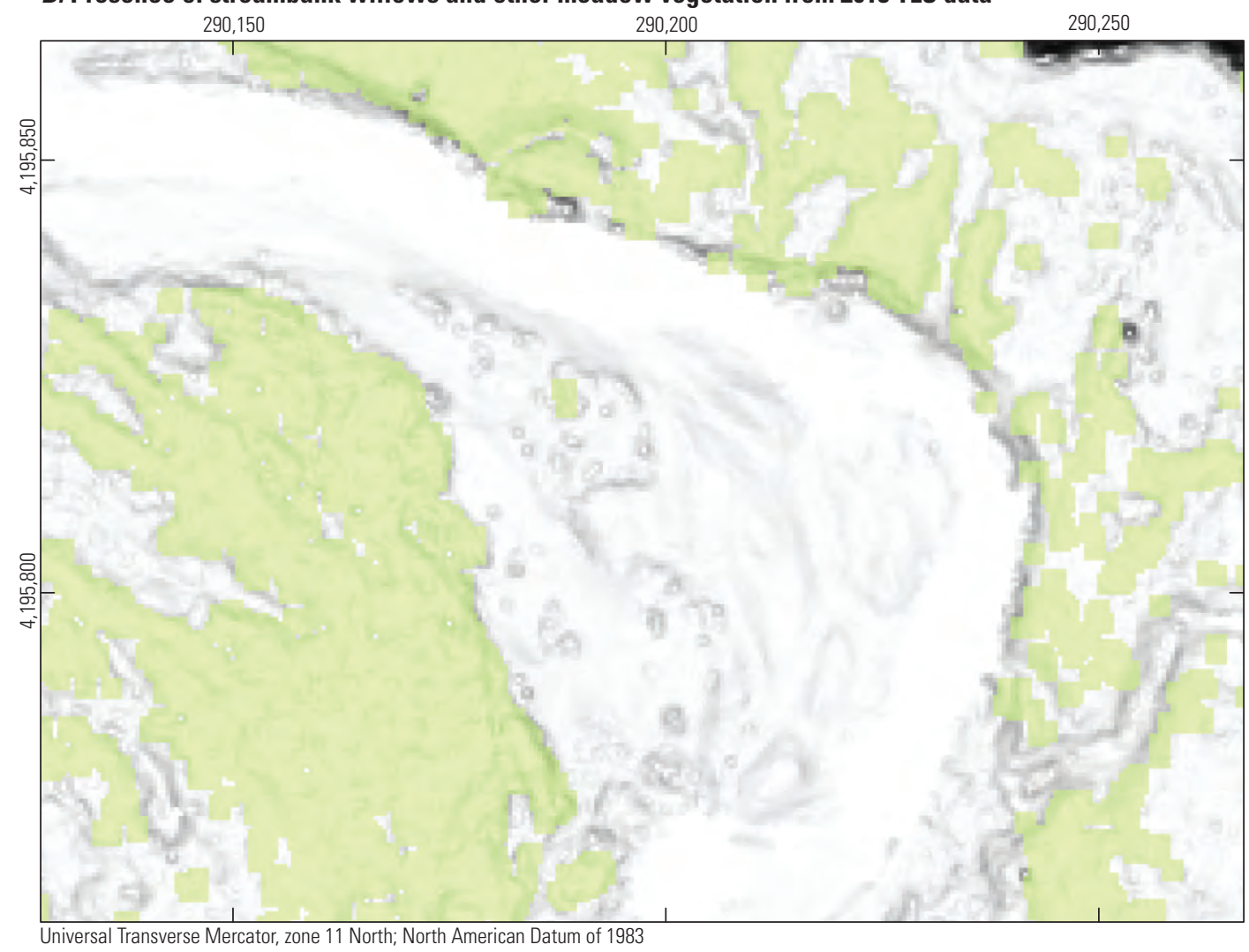

EXPLANATION

Canopy height, in meters

0.25 to 1 -Short vegetation

1 to 4-Mostly willows

Figure 51. Lidar-derived maps of vegetation at erosion zone 15. Data are from 2018 terrestrial laser scanning (TLS). A, shows a semitransparent canopy-height model over full-feature slopeshade. $B$, shows a map of vegetation most likely to be streambank willows and meadow vegetation. 

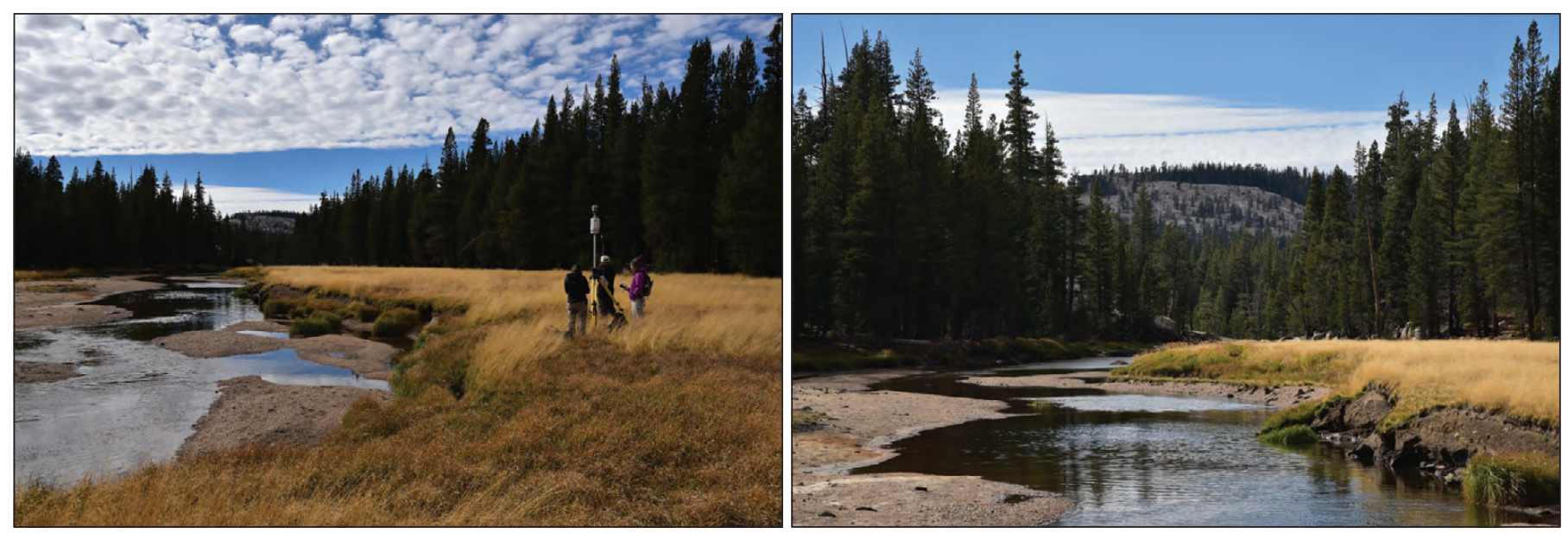

Figure 52. U.S. Geological Survey photographs of erosion zone 15, taken in 2018.

Table 17. Estimates of erosion and deposition at erosion zone 15 along Tuolumne River.

[---, no data; DEM, digital elevation model; DoD, DEMs of difference; $\mathrm{m}$, meter; $\mathrm{m}^{2}$, square meter; $\mathrm{m}^{3}$, cubic meter]

\begin{tabular}{|c|c|c|c|c|c|c|c|c|}
\hline \multirow[b]{2}{*}{$\begin{array}{l}\text { Erosion } \\
\text { zone }\end{array}$} & \multirow[b]{2}{*}{$\begin{array}{l}\text { Surveyed } \\
\text { interval }\end{array}$} & \multirow[b]{2}{*}{$\begin{array}{c}\text { Streambank } \\
\text { or bar }\end{array}$} & \multicolumn{2}{|c|}{ From DEM change mapping } & \multicolumn{4}{|c|}{ From streambank mapping } \\
\hline & & & $\begin{array}{l}\text { Area of data } \\
\text { in zone }\left(\mathrm{m}^{2}\right)\end{array}$ & $\begin{array}{l}\text { Volume change } \\
\text { from } \operatorname{DoD}_{\left(\mathrm{m}^{3}\right)}\end{array}$ & $\begin{array}{c}\text { Active } \\
\text { streambank } \\
\text { length }(\mathbf{m})\end{array}$ & $\begin{array}{c}\text { Bank } \\
\text { height (m) }\end{array}$ & $\begin{array}{c}\text { Average bank } \\
\text { retreat }(\mathrm{m})\end{array}$ & $\begin{array}{c}\text { Volume change } \\
\text { from streambank } \\
\text { mapping }\left(\mathrm{m}^{3}\right)\end{array}$ \\
\hline 15 & 2006-2016 & Bank & --- & --- & --- & --- & --- & --- \\
\hline 15 & 2006-2017 & Bar & 2,333 & $\mathrm{a}-7.0$ & --- & --- & --- & --- \\
\hline 15 & $2006-2018$ & Bank & 563 & a -59.0 & --- & --- & --- & --- \\
\hline 15 & 2016-2017 & Bar & --- & --- & --- & --- & --- & --- \\
\hline 15 & 2016-2017 & Bank & --- & --- & --- & --- & --- & --- \\
\hline 15 & 2017-2018 & Bar & 1,778 & b-25.6 & --- & --- & --- & --- \\
\hline 15 & 2017-2018 & Bank & 359 & $\mathrm{~b}-8.4$ & 20 & 1.30 & 0.05 & -1.5 \\
\hline
\end{tabular}

${ }^{\mathrm{a}}$ Calculated from 50-cm-resolution digital elevation models at 4-cm level of detection.

${ }^{\mathrm{b}} \mathrm{Calculated}$ from $10-\mathrm{cm}-$ resolution digital elevation models at $2-\mathrm{cm}$ level of detection. 


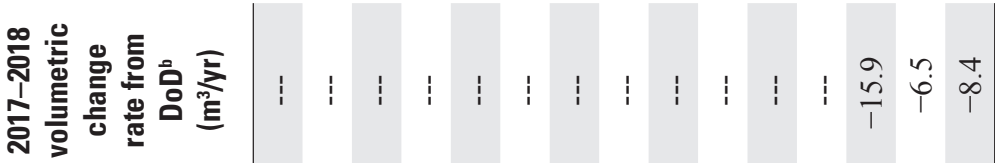

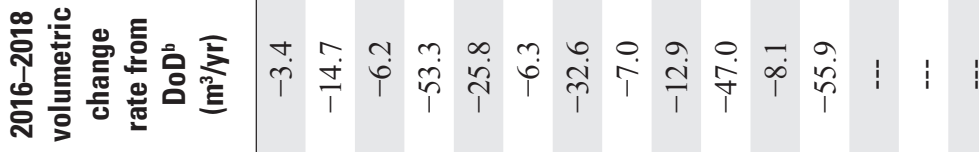

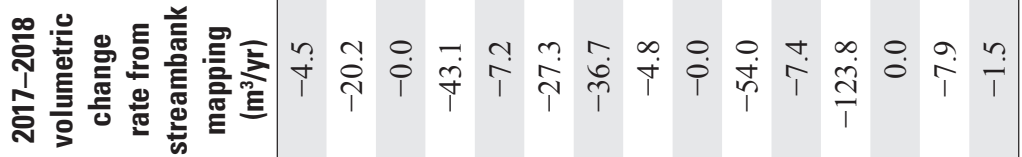

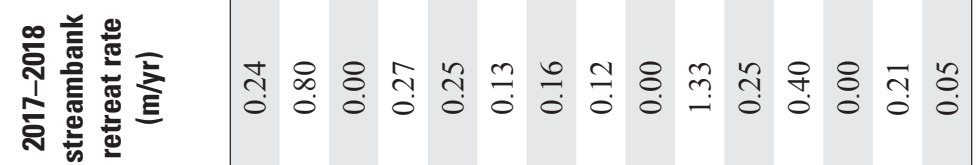

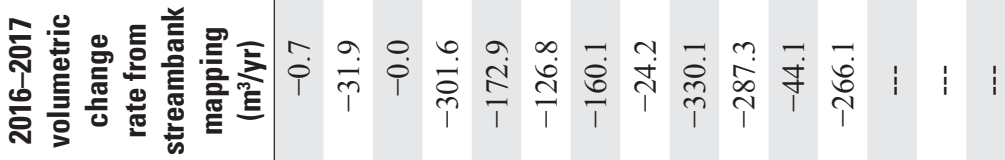

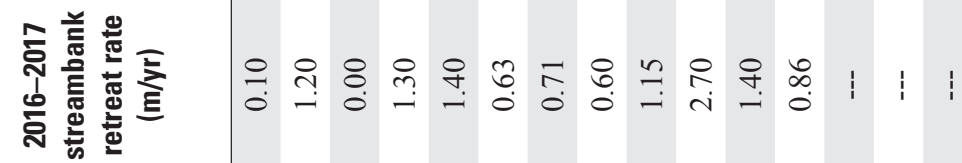

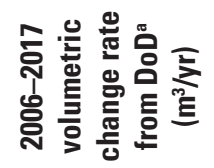

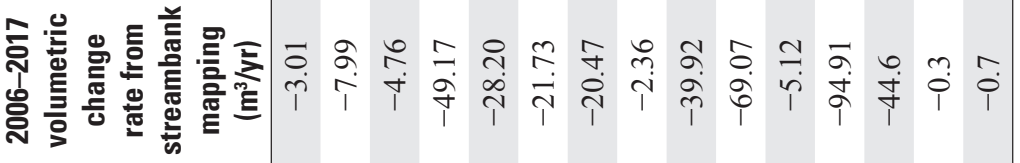

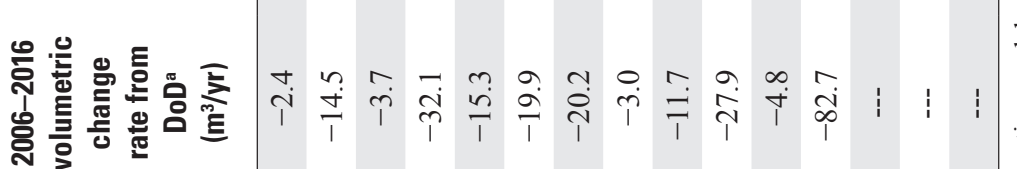

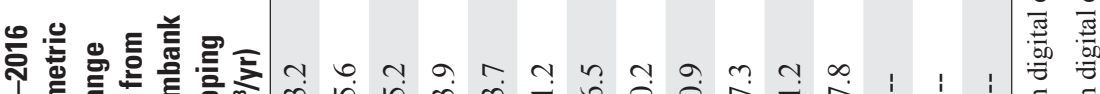

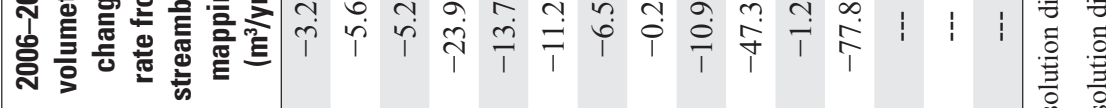

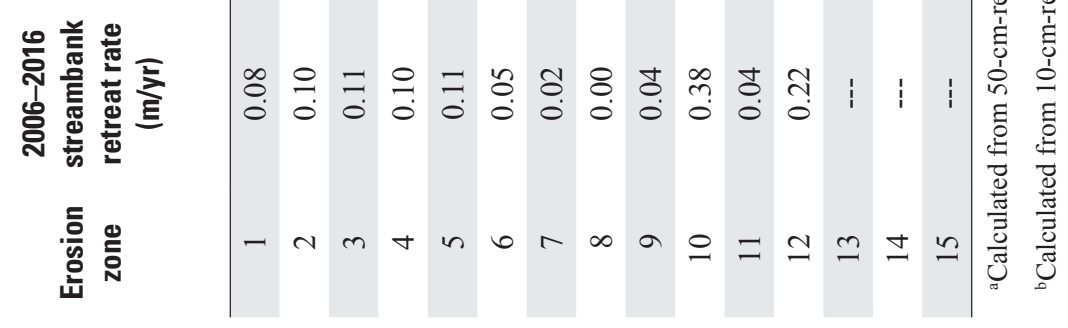


Table 19. Rates of sediment deposition on point and channel bars opposite eroding streambanks along Tuolumne River.

[---, no data; DEM, digital elevation model; DoD, DEMs of difference; $\mathrm{m}$, meter; $\mathrm{m}^{2}$, square meter; $\mathrm{m}^{3}$, cubic meter, yr, year]

\begin{tabular}{|c|c|c|c|c|c|}
\hline $\begin{array}{c}\text { Erosion } \\
\text { zone }\end{array}$ & $\begin{array}{l}\text { 2006-2016 volumetric } \\
\text { change rate from DoD } \\
\left(\mathrm{m}^{3} / \mathrm{yr}\right)\end{array}$ & $\begin{array}{l}\text { 2006-2017 volumetric } \\
\text { change rate from DoD } \\
\left(\mathrm{m}^{3} / \mathrm{yr}\right)\end{array}$ & $\begin{array}{l}\text { 2016-2017 volumetric } \\
\text { change rate from } D_{0} D^{\mathrm{b}} \\
\left(\mathrm{m}^{3} / \mathrm{yr}\right)\end{array}$ & $\begin{array}{l}\text { 2017-2018 volumetric } \\
\text { change rate from DoD } \\
\left(\mathrm{m}^{3} / \mathrm{yr}\right)\end{array}$ & $\begin{array}{l}\text { 2016-2018 volumetric } \\
\text { change rate from DoD } \\
\left(\mathrm{m}^{3} / \mathrm{yr}\right)\end{array}$ \\
\hline 1 & 1.5 & --- & 4.2 & 1.2 & 3.4 \\
\hline 2 & 0.4 & --- & 3.1 & -1.1 & 4.4 \\
\hline 3 & 2.8 & --- & 52.8 & -1.1 & 34.0 \\
\hline 4 & 9.2 & --- & 164.8 & -63.9 & 103.1 \\
\hline 5 & 8.6 & --- & 101.5 & 14.1 & 65.6 \\
\hline 6 & -6.8 & --- & 46.5 & 2.6 & 40.8 \\
\hline 7 & -13.4 & --- & 120.3 & -13.2 & 70.9 \\
\hline 8 & -6.4 & --- & 35.9 & -0.9 & 21.6 \\
\hline 9 & -6.0 & --- & 224.5 & -1.3 & 129.8 \\
\hline 10 & 1.2 & --- & 149.1 & -33.7 & 85.8 \\
\hline 11 & -2.0 & --- & 153.3 & -52.7 & 52.1 \\
\hline 12 & 40.3 & --- & 132.5 & -102.5 & 16.5 \\
\hline 13 & --- & 17.8 & --- & -3.7 & --- \\
\hline 14 & --- & 27.6 & --- & 4.5 & --- \\
\hline 15 & --- & -0.7 & --- & -25.6 & --- \\
\hline
\end{tabular}

${ }^{\mathrm{a}}$ Calculated from 50-cm-resolution digital elevation models at 4-cm level of detection.

${ }^{\mathrm{b}}$ Calculated from 10-cm-resolution digital elevation models at 2-cm level of detection.

\section{Discussion}

Streambank position and sediment storage on point and channel bars have changed in response to floods in Tuolumne Meadows from 2006 to 2018 . The dominate type of river channel change was meander growth (Hooke, 1984). As is typical in meandering river systems, meander growth occurred by erosion on the outer streambanks at the bends in the river. It was complemented by sediment deposition on point bars opposite of the eroding streambanks and less frequently on channel bars. Based on the presence of willows and other vegetation on the higher parts of most point bars, it may take years for vegetation to establish on these bars, giving the impression that the more visually striking streambank retreat is occurring at a more rapid rate than establishment of vegetated point bars. The lowest, most active point bars are characterized by vegetation-free deposits of sand and gravel that receive episodic deposition in flood events. The geomorphic processes of erosion and deposition occur episodically along the Tuolumne River channel, and over the full duration of the study (2006-2018) there was net deposition of over $800 \mathrm{~m}^{3}$ of sediment in the above-water areas along the Tuolumne River (table 20). Note that this is not simply a sum of the analyses at erosion zones but also incorporates change between erosion zones. Several areas not included in the 15 erosion zones defined in this study clearly influence this volumetric budgeting. These include: erosion and deposition just upstream of erosion zone 4; erosion and deposition at the large channel bar between erosion zones 10 and 11; erosion and deposition on bars, and, to a very limited extent, streambank erosion between erosion zones 11 and 12; erosion and deposition downstream of erosion zone 12; some modification of channel bars upstream of erosion zone 14; substantial deposition of the first channel bar downstream of erosion zone 14; erosion of channel and point bars at the horseshoe-shaped bend in the channel upstream of erosion zone 15 , and erosion of channel bars downstream of erosion zone 15.

The relationship between flooding and stream channel change is complex. For example, the flood of 2017 led to a pronounced episode of deposition; nearly $1,600 \mathrm{~m}^{3}$ of sediment was deposited over $0.033 \mathrm{~km}^{2}$ of the channel and near-channel area, but then a net of about $1,100 \mathrm{~m}^{3}$ of sediment was removed from $0.051 \mathrm{~km}^{2}$ over the following year, which was characterized by less severe flooding (table 20).

Furthermore, there was considerable spatial variability in erosion and deposition. Some erosion zones had net erosion over the same time periods that others had net deposition. There is no clear relationship between the amount of streambank erosion in a location and the amount of deposition at bars in the same location. This indicates that erosion and deposition are not coupled at each bend in a river and that the response to flooding does not follow a systematic pattern.

Previous research on streambank erosion in similar settings provides a framework for discussing Tuolumne Meadows 


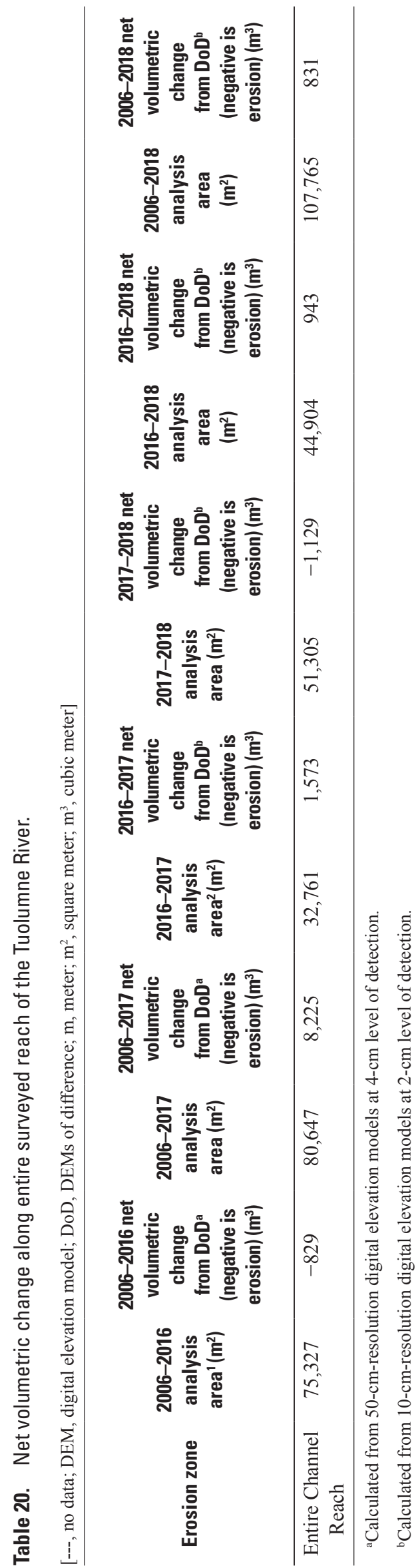

and clarifying the process and controls relating to streambank migration. Streambanks in these settings are often characterized by an upper layer of soil and sediment that is cohesive owing to the strength of meadow vegetation root structure, and possibly to the presence of silt, clay, and organic particles that can strengthen the material (Micheli and Kirchner, 2002b; Eke and others, 2014). Under the cohesive layer are unconsolidated fluvial sediments that have lower shear strength than the upper cohesive layer. If the streambanks are high enough above the water surface, the lower, weaker sediment is susceptible to erosion by flowing water. This can undermine the upper cohesive layer which then erodes via cantilever failure (Samadi and others, 2013). During this process, if a channel incises vertically into the stream bed, it can lead to enhanced lateral streambank migration (Micheli and Kirchner, 2002b). The failure of the upper cohesive material leads to the presence of blocks of sediment held together by roots and vegetation. These blocks serve to armor the lower part of the streambank exposure until they are removed by further fluvial action, which may take a few years (Eke and others, 2014). The type of vegetation, as well as its root structure, may be a primary control on streambank migration rates. For example, Micheli and Kirchner (2002a) found that "dry meadow" vegetation such as sagebrush provides less root strength than "wet meadow" vegetation, and that dry meadow streambank migration occurs more rapidly than wet meadow streambank migration. As streams incise, vegetation can change from "wet" to "dry" (DarrouzetNardi and others, 2006) because of decreased water availability if water tables are lowered. This would encourage increased rates of streambank migration. We did not observe vegetation such as sagebrush that often characterize dry meadows, but it is possible that future vegetation changes owing to change in stream channel morphology, groundwater level or other climate/precipitation/ hydrological changes could affect rates of streambank migration in Tuolumne Meadows.

What leads to temporal and spatial variability of streambank erosion and bar deposition in Tuolumne Meadows? Since banks erode when boundary shear stress exceeds material strength, the angle at which the flowing water makes contact with the streambank may be important (Eke and others, 2014). This is approximated by local sinuosity, reported in table 21, though shorter-wavelength channel variability found at erosion zone 10 are not captured by traditional measures of sinuosity but appear important in affecting rates of streambank migration.

When the relationship between rates of erosion and sinuosity were investigated (figs. 53-55), a weak dependence of erosion rate on sinuosity emerged. This relationship was more easily observed as a function of volumetric change than streambank retreat rate. The reason for this is not clear, though the volumetric change rate may be better at capturing processes such as the removal of a transient slump block and other material near the streambank than the streambank retreat rate. The very local flow patterns, nature of streambank material properties, and vegetation cover may provide strong influence on streambank erosion, these factors are not captured by the sinuosity metric alone. This may be an indication that site-specific assessments are needed to improve understanding or guide mitigation efforts. 
Measuring the strength of streambank material is challenging (Micheli and Kirchner, 2002b; Yildiz and others, 2018) and no data exist to evaluate the spatial variability of streambank erodibility or material properties in Tuolumne Meadows. It is worth noting that the erosion zone with the highest sinuosity by a wide margin is the large bend at erosion zone 12 . There, some of the highest streambank erosion rates occur along the Tuolumne River channel. At this zone, deposition is occurring along a part of the eroding streambank (figs. 41-43). If channel bar deposition continues, island formation or deposition at the base of the streambank may lead to bank stabilization and channel migration back towards the opposite point bar, rather than continued meander growth, or the channel bar may stabilize and focus flow farther to the west, leading to accelerated channel migration.

The location where the highest streambank retreat rates occurred is at the unusually shaped bend in channel pattern at erosion zone 10 (fig. 35). The measured sinuosity of this bend is not particularly high because it is measured over a length scale which incorporates adjacent channel bends; the zone of erosion is a local sharpening of an otherwise gradual bend in the river as measured on a longer channel centerline distance, so the angle of incidence of flow and resultant shear stress may be particularly high. This bank retreated several meters during
Table 21. Sinuosity at zones of streambank erosion along Tuolumne River.

\begin{tabular}{cccc}
\hline $\begin{array}{c}\text { Erosion } \\
\text { zone }\end{array}$ & $\begin{array}{c}\text { Straight-line } \\
\text { distance }(\mathbf{m})\end{array}$ & $\begin{array}{c}\text { Channel centerline } \\
\text { distance }(\mathbf{m})\end{array}$ & $\begin{array}{c}\text { Sinuosity } \\
(\mathbf{m} / \mathbf{m})\end{array}$ \\
\hline 1 & 260 & 290 & 1.12 \\
\hline 2 & 276 & 303 & 1.10 \\
\hline 3 & 285 & 312 & 1.09 \\
\hline 4 & 219 & 328 & 1.50 \\
\hline 5 & 456 & 503 & 1.10 \\
\hline 6 & 352 & 381 & 1.08 \\
\hline 7 & 524 & 596 & 1.14 \\
\hline 8 & 347 & 362 & 1.04 \\
\hline 9 & 480 & 544 & 1.13 \\
\hline 10 & 236 & 321 & 1.36 \\
\hline 11 & 264 & 320 & 1.21 \\
\hline 12 & 108 & 336 & 3.11 \\
\hline 13 & 440 & 474 & 1.08 \\
\hline 14 & 316 & 591 & 1.87 \\
\hline 15 & 350 & 512 & 1.46 \\
\hline
\end{tabular}

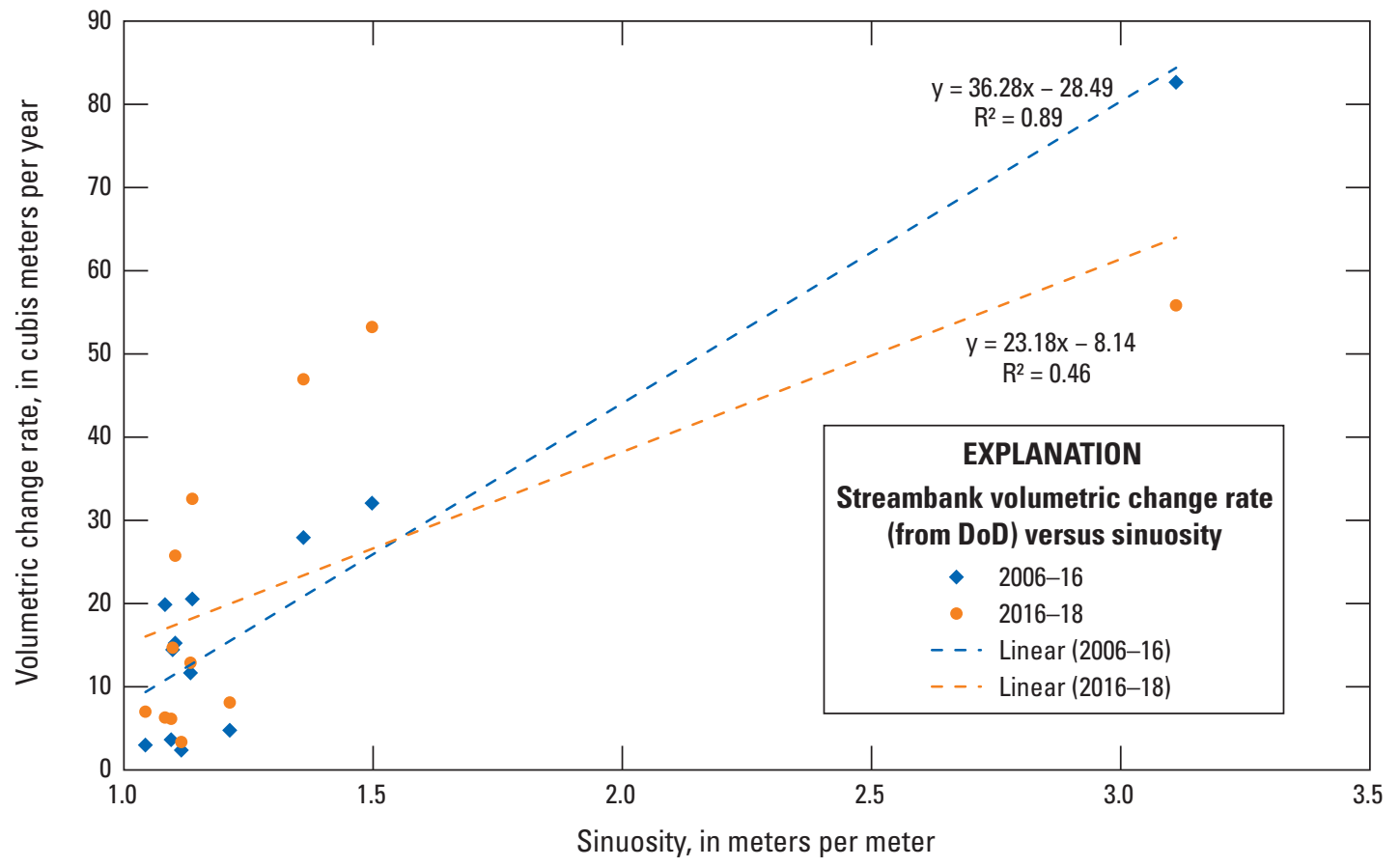

Figure 53. Graph of streambank volumetric change rate versus sinuosity along the Tuolumne River channel measured at eroding streambanks. Volumetric change rate is in cubic meters per year as calculated from a subtraction of digital elevation models (DEMs) to create a DEM of difference (DoD). Only low-water conditions data from 2006, 2016, and 2018 are displayed. 


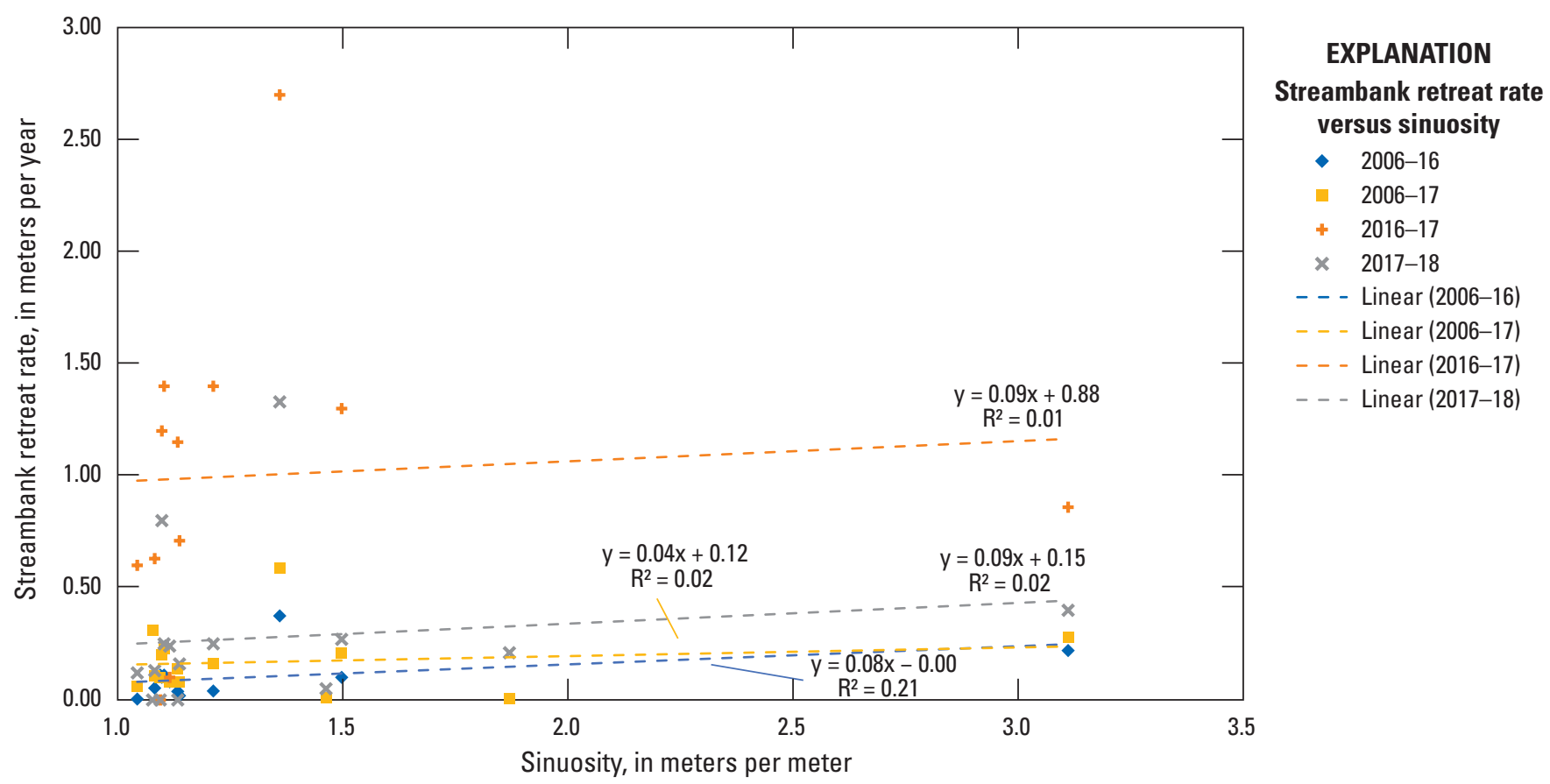

Figure 54. Graph of streambank retreat rate versus sinuosity along the Tuolumne River channel measured at migrating streambanks. Streambank retreat rate in meters per year as calculated from mapping of streambank positions from lidar data. Distances represent the average retreat along the length of eroding streambank, including some areas of no position change between areas of substantial change.

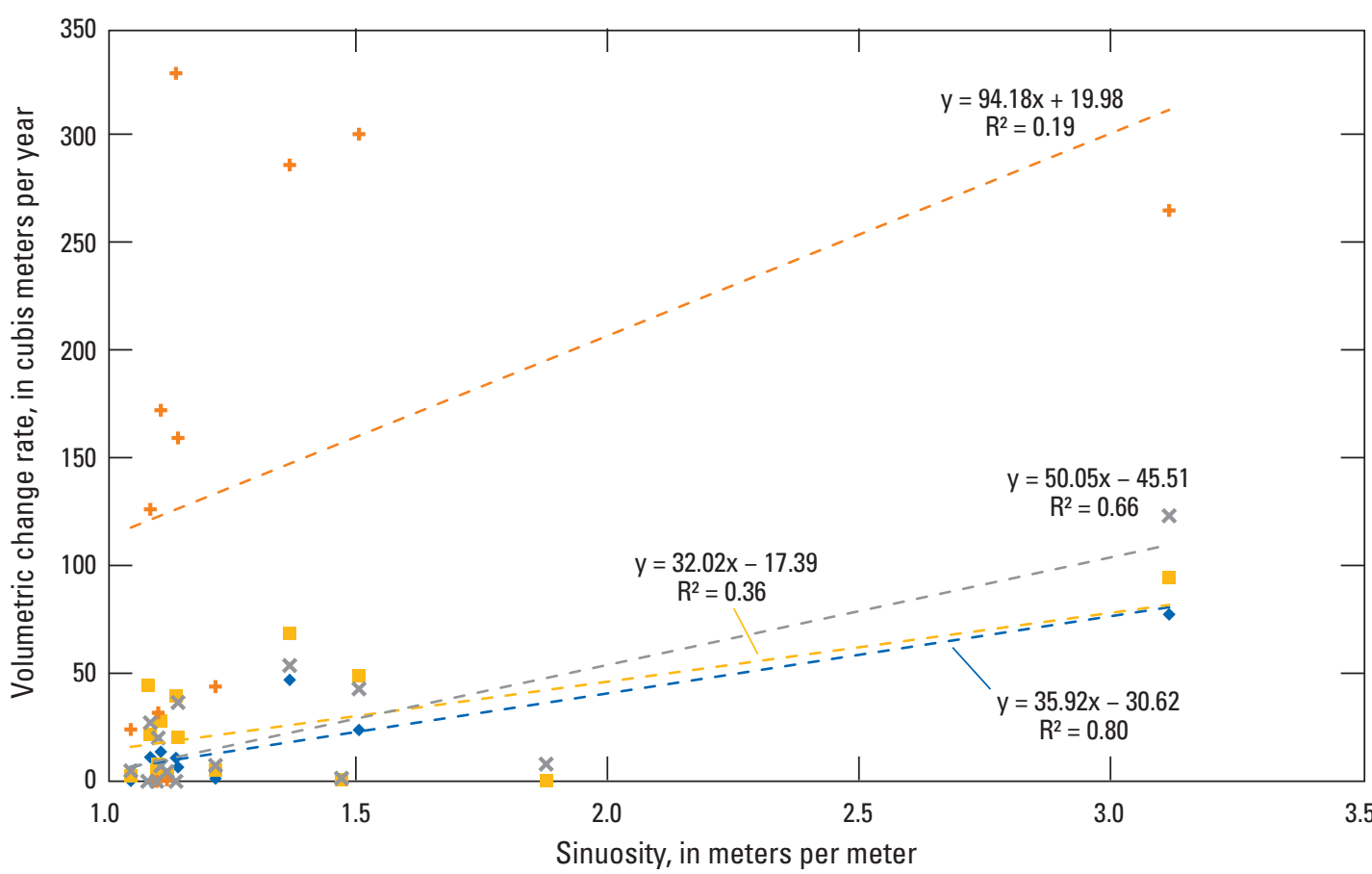

EXPLANATION

Streambank volumetric change rate (from mapping) versus sinuosity

- 2006-16

- 2006-17

$+\quad 2016-17$

$\times \quad 2017-18$

- - - Linear (2006-16)

- - - Linear (2006-17)

- - - Linear (2016-17)

- - - Linear (2017-18)

Figure 55. Graph of streambank volumetric change rate (from mapping) versus sinuosity along the Tuolumne River channel. Volumetric change rate is in cubic meters per year as calculated from volume generated from mapping of streambank position from lidar data and using the local streambank height in 2018 during low-water conditions. This assumes all material is removed as streambanks retreat which may not be the case each year as evidenced by the slower removal of collapsed streambank blocks, but likely over time collapsed material is removed as streambanks retreat. 
the study period, and as it continues will become a test for the efficacy of streambank willows at controlling streambank erosion (fig. 36). This may be a location where meander cutoff occurs in the next few decades owing to typical floods or more rapidly in a large flood. It is the only location where strong evidence for recent (though pre-2006) channel avulsion through a point bar has occurred. Erosion zone 10 also has the most vegetation present at the retreating streambank so it could be a location at which the efficacy of streambank willows on top of streambanks as erosion mitigation may be evaluated in the coming years. Between zones 10 and 11 a sharp westward bend in the river was not classified as an erosion zone, though there is evidence for limited erosion. In this location, conifers sit above the streambank, possibly increasing the bank's resistance to erosion. Several other sharp bends in the river (for example, between zones 3 and 4, 4 and 5,12 and 13, and 14 and 15) are characterized by the presence of bedrock outcrops or streambanks cut into higher terraces or colluvial deposits, all of which seem to prevent substantial erosion.

The temporal variability in erosion rates may be controlled by the magnitude of floods. Floods in the Tuolumne River are largely a product of melting snowpack, occurring regularly in May and (or) June each year (fig. 56). Rain, such as the storms that occurred in October 2010 and April 2018, can also generate runoff. Rain-caused floods tend to have an event hydrograph with a steeper rising limb and more rapid discharge recession than seasonal snowmelt, which is often characterized by diurnal fluctuations superposed on rising streamflow trends over days to weeks followed by recession over days to weeks. Streamflow data indicate that the 2017 peak flow event had the highest discharge during study years at about $82.75 \mathrm{~m}^{3} / \mathrm{sec}$. This led to the most pronounced landscape change, and there is no evidence that comparable landscape change occurred between 2006 and 2017. During the study period, the next-highest measured floods peaked at $53.14 \mathrm{~m}^{3} / \mathrm{s}$ during snowmelt in June $2010 ; 52.18 \mathrm{~m}^{3} / \mathrm{s}$ in a rain-induced runoff event in April 2018; and $46.08 \mathrm{~m}^{3} / \mathrm{s}$ in snowmelt runoff in June 2011. All other years had substantially lower peak discharge, almost certainly including the missing data from late 2008 through early 2009, during which no remarkable floods were recorded at the next gage downstream: (https://nwis. waterdata.usgs.gov/ca/nwis/peak?site_no $=11274790 \&$ agency $\mathrm{cd}=$ USGS\& format $=\mathrm{html}$, accessed April 24, 2020).

Although the 2018 rain-caused flood may have caused landscape change, the snowmelt floods in 2010 and 2011 had high peak flows and longer durations. Because snowmelt floods vary diurnally, they are compared here in terms of number of days with peak flows greater than $30 \mathrm{~m}^{3} / \mathrm{s}$, and number of nights with flows that are greater than $20 \mathrm{~m}^{3} / \mathrm{s}$. The 2017 floods had peak flows greater than $30 \mathrm{~m}^{3} / \mathrm{s}$ on 48 days (including a single day in September owing to rainfall) and nighttime minimum flows greater than $20 \mathrm{~m}^{3} / \mathrm{s}$ for 46 days, whereas the 2010 floods had peak flows greater than $30 \mathrm{~m}^{3} / \mathrm{s}$ on 9 days and nighttime minimum flows greater than $20 \mathrm{~m}^{3} / \mathrm{s}$ for 7 days, and the 2011 floods had peak flows greater than $30 \mathrm{~m}^{3} / \mathrm{s}$ on 25 days and nighttime minimum flows greater than $20 \mathrm{~m}^{3} / \mathrm{s}$ for 22 days. Because the landscape change from 2017 was more substantial than that from 2006-2016 in many locations, the magnitude, duration or some combination of those in 2017 may have exceeded an important threshold

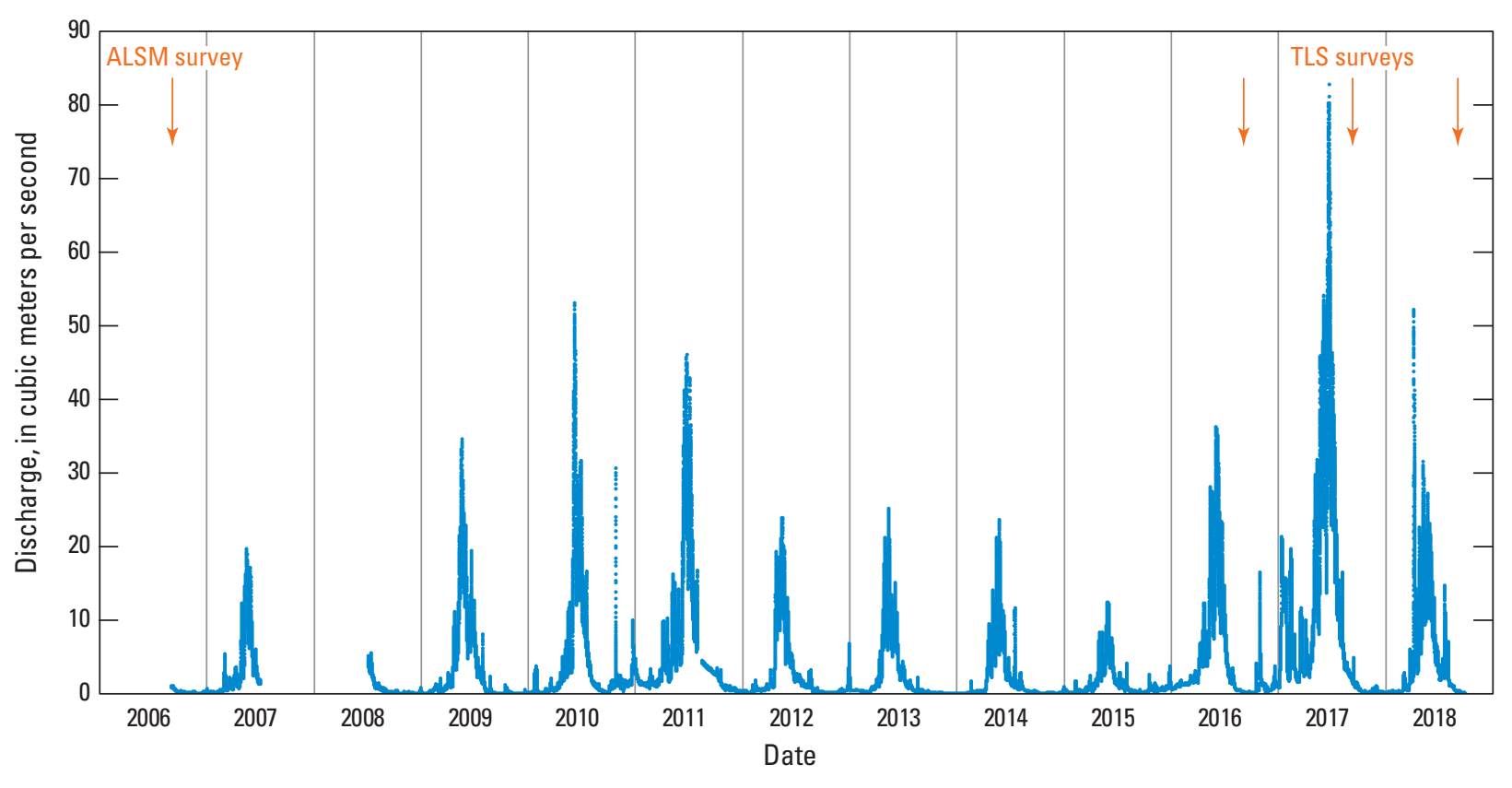

Figure 56. Graph of stream discharge along the Tuolumne River upstream of Tuolumne Meadows at gage "TUM" from 2006 to 2018. Gage is located just upstream of the study area near the California Highway 120 (Tioga Road) bridge over the Tuolumne River. The approximate times of lidar surveys are also indicated with arrows. There are no data for late 2007 and early 2008, but regional records indicate it was an unremarkable period hydrologically. Streamflow data are available at: https://irma.nps.gov/AQWebPortal/Data/Location/Summary/Location/SIEN_YOSE_TUOLTIRO/Interval/Latest. 
for causing landscape change. The fairly minimal landscape change that occurred in 2018 resulted from a peak snowmelt flow of $31.52 \mathrm{~m}^{3} / \mathrm{s}$ with just a single day with peak flow greater than $30 \mathrm{~m}^{3} / \mathrm{s}$ and zero nights with minimum flows greater than $20 \mathrm{~m}^{3} / \mathrm{s}$ for 46 days, and the rain-caused flood in April that had a peak discharge of $52.18 \mathrm{~m}^{3} / \mathrm{s}$ and (nondiurnally varying) flow greater than $20 \mathrm{~m}^{3} / \mathrm{s}$ for about 1 day and 21 hours. The relative geomorphic importance of the runoff caused by rain in April versus the snowmelt from April through June is not known, though it is reasonable to characterize the 2018 snowmelt runoff as unremarkable compared to other years.

The most common process by which streambanks erode in Tuolumne Meadows is undermining and failure of blocks of sediment (for example figs. 19, 28, 43, and 46). The short meadow vegetation that grows on top of the main valley surface adjacent to eroding streambanks appear to have shallow roots confined to the upper fine grained and organic-rich soil. This may indicate that erosion below roots leads to undermining and mass wasting of channel material via cantilever failure (Micheli and Kirchner, 2002a). This may cause the common overhanging nature of eroding channels, though vertical variation in material properties of the sediment along the soil profile may also be a factor in causing overhanging features in layered sedimentary material (for example DeLong and others, 2014). These overhanging blocks are gradually removed by subsequent floods.

Deposition on point and channel bars occurred along with erosion of streambanks. Erosion was likely to have occurred during peak flow owing to high shear stress on channel banks, and deposition likely occurred as floods waned and sediment transport capacity lowered. Over the course of the study, deposition may have slightly exceeded erosion, about $829 \mathrm{~m}^{3}$ of sediment increase was measured between 2006 and 2018 . (Table 20). There was considerable variation among the survey intervals, however. For example, between 2006 and 2016 a net loss of about $829 \mathrm{~m}^{3}$ of sediment occurred. Furthermore, data indicate that the 2017 floods led to particularly high rates of deposition along the channel reach, and much of that material was apparently removed downstream or transferred to deeper parts of the channel in 2018. These results indicate that a measurement for any given year or number of years may not indicate long-term trends. During some periods there is net deposition along the Tuolumne River and during others there is net erosion. The oscillation may indicate that most change is temporary, and the long-term trend may not be towards either overall erosion or aggradation of the Tuolumne River in Tuolumne Meadows.

Extensive channel widening was not observed in Tuolumne Meadows. Deposition occurs most commonly on the part of the point bars closest to the channel thalweg, and channel and point bars often enlarged over the period of study. At one end of the spectrum, erosion zone 12 (fig. 41) shows the location of one of the most rapidly migrating active streambanks. In this location, as the streambank is migrating rapidly, extensive deposition is occurring, though generally at a volumetric rate about half of the rate of removal of sediment by bank erosion (table 13). It is not apparent if the channel thalweg is deepening or becoming shallower because none of the laser instruments used in this study can image bathymetry. Green-laser "topo-bathymetric" airborne laser scanners now available to monitor the coevolution of topography and bathymetry could be used for ongoing monitoring. Unlike other alluvial systems that undergo substantial cycles of incision and aggradation, the Tuolumne River has a stable base level as controlled by the bedrock feature at the meadow outlet (fig. 2). If a flood causes substantial erosion into this bedrock channel reach, channel incision could occur in Tuolumne Meadows, but it is likely that bedrock erosion is very slow where this resistant igneous rock underlies the channel.

\section{Conclusions}

To support management decisions to be made according to the Tuolumne Wild and Scenic River Final Comprehensive Management Plan, monitoring of streambank positions, sediment erosion and deposition, and the changes to the landscape along the Tuolumne River in Tuolumne Meadows were performed using lidar data collected in 2006, 2016, 2017, and 2018. Streambank erosion is balanced or even exceeded by sediment deposition on point and channel bars from 2006 to 2018 along the Tuolumne River in Tuolumne Meadows. Individual floods may lead to periods of accelerated erosion and deposition, though data collected are insufficient to predict the amount of erosion or deposition as a function of streamflow peak discharge or duration. The zones of highest erosion have high local sinuosity though the statistical relationship between sinuosity and erosion is not clear. Where bends in the river appear to be the most stable, resistant features are present such as bedrock outcrops, conifers, and exposures of colluvium or older alluvium. The relationship between the presence of riparian willows and streambank erosion or deposition is not clear. However, based on the presence of young willows on point bars, it is apparent that over time, willows may establish in greater numbers along streambanks in Tuolumne Meadows. The highest rates of streambank erosion measured in this study were caused by high peak discharge in 2017. Streambank erosion in 2017 exceeded observed erosion from 2006 to 2016 and in 2018. Future floods with higher discharge or longer duration than those in 2017 may lead to accelerated landscape change including streambank migration and sediment deposition. Some sediment deposited following large floods may be removed in subsequent floods. Future study of Tuolumne Meadows landscape change could include topo-bathymetric lidar surveys to better investigate possible changes in channel bed elevation, characterization of streambank material properties, investigation of vegetation dynamics, research into the effects of various vegetation types on streambank stability and (or) migration, monitoring of shallow ground water, and use of hydrological and hydrogeomorphic modeling 
for prediction of the effects of extreme hydrological events which might be caused by heavy rain on deep snowpack in a warming climate. With respect to some of the language in the Tuolumne Wild and Scenic River Final Comprehensive Management Plan (National Park Service, 2014), these results indicate that hydrological variability, rather than vegetation distribution, visitor activity, or other factors may be the primary cause of streambank and river channel change in Tuolumne Meadows. High-magnitude flood events caused by increased rainfall and rapid snowmelt in a changing climate may drive future landscape change in Tuolumne Meadows. Sediment deposition will occur with concomitant erosion during floods in this naturally dynamic landscape.

\section{References Cited}

Becker, R.A., Tikoff, B., Riley, P.R., Iverson, N.R., 2014, Preexisting fractures and the formation of an iconic American landscape - Tuolumne Meadows, Yosemite National Park, USA: Geological Society of America, v. 10, no. 11, accessed August 03, 2019, at https://doi.org/10.1130/GSATG203A.1.

Buhler, M., Beatty, S., Ballenger, L., Schiable, D., 2010, Ecological Restoration Planning for the Tuolumne Wild and Scenic River Comprehensive Management Plan, with Introduction by Lisa Acree: Division of Resources Management and Science.

Cooper, D.J., Lundquist, J.D., King, J., Flint, A., Flint, L., Wolf, E., Lott, F.C., Roche, J., 2006, Effects of the Tioga Road on Hydrologic Processes and Lodgepole Pine Invasion into Tuolumne Meadows, Yosemite National Park: American Geophysical Union.

Darrouzet-Nardi, A., D’Antonio, C.M., Dawson, T.E., 2006, Depth of water acquisition by invading shrubs and resident herbs in a Sierra Nevada meadow: Plant Soil, v. 285: p. 31-43, accessed August 03, 2019, at https://doi.org/10.1007/s11104-005-4453-Z.

DeLong, S.B. and Pickering, A.J., 2020, Lidar point cloud, raster, mapping, analysis, and photographic data for streambank erosion and related geomorphic change in Tuolumne Meadows, Yosemite National Park: U.S. Geological Survey data release, accessed May 13, 2020, at https://doi.org/10.5066/P9Z2QICU.

DeLong, S.B., Johnson, J.P.L., Whipple, K.X, 2014, Arroyo channel head evolution in a flash-flood-dominated discontinuous ephemeral stream system: Geological Society of America, v. 126, no. 11-12, p. 1683-1701, accessed August 03, 2019, at https://doi.org/10.1130/B31064.1.

Dull, R.A., 1999, Palynological evidence for 19th century grazing-induced vegetation change in the southern Sierra Nevada, California, USA: Journal of Biogeography, v. 26, no. 4, p. 899-912, https://doi.org/10.1046/j.1365-2699.1999.00330.x.
Eke, E., Parker, G., and Shimizu, Y., 2014, Numerical modeling of erosional and depositional bank processes in migrating river bends with self-formed width-Morphodynamics of bar push and bank pull, Journal of Geophysical Research - Earth Surface, v. 119, no. 7, p. 1455-1483, accessed May 08, 2019, at https://doi.org/10.1002/2013JF003020.

Hooke, J.M., 1984, Changes in river meanders - a review of techniques and results of analyses: Progress in Physical Geography: Earth and Environment, v. 8, no. 4, p. 473-508, accessed May 09, 2019, at https://doi. org/10.1177/030913338400800401.

Lague, D., Brodu, N., Leroux, J., 2013, Accurate 3D comparison of complex topography with terrestrial laser scanner - application to the Rangitikei canyon (N-Z): ISPRS Journal of Photogrammetry and Remote Sensing, v. 82, p. 10-26, accessed August 3, 2019, at https://doi. org/10.1016/j.isprsjprs.2013.04.009.

Loheide, S.P. and Booth, E.G., 2011, Effects of changing channel morphology on vegetation, groundwater, and soil moisture regimes in groundwater dependent ecosystems: Geomorphology, v. 126, no. 3-4: p. 364-376, accessed May 09, 2019, at https://doi.org/10.1016/j. geomorph.2010.04.016.

Loheide, S.P., Deitchman, R.S., Cooper, D.J., Wolf, E.C., Hammersmark, C.T., and Lundquist, J.D., 2009, A Framework for Understanding the Hydroecology of Impacted Wet Meadows in the Sierra Nevada and Cascade Ranges, California, USA: Hydrogeology Journal, v. 17, no. 1, p. 229-246.

Micheli, E.R. and Kirchner, J.W, 2002b, Effects of wet meadow riparian vegetation on streambank erosion. 2. Measurements of vegetated bank strength and consequences for failure mechanics: Earth Surface Processes and Landforms, v. 27, no. 6, p. 687-697, accessed August 03, 2019, at https://doi. org/10.1002/esp.340.

Micheli, E.R. and Kirchner, J.W., 2002a, Effects of wet meadow riparian vegetation on streambank erosion. 1. Remote sensing measurements of streambank migration and erodibility: Earth Surface Processes and Landforms, v. 27, no. 6, p. 627-639, accessed August 03, 2019, at https://doi. org/10.1002/esp.338.

National Park Service, 2014, Tuolumne Wild and Scenic River Final Comprehensive Management Plan and Environmental Impact Statement. 822 p., accessed May 09, 2019, at https:// www.nps.gov/yose/learn/management/upload/Tuolumne-Wildand-Scenic-River-Final-Comprehensive-Management-Planand-Environmental-Impact-Statement-Vol-1-and-2.pdf.

Pack, R.T., Blonquist, K., Carter, B., 2012, Lidar Bare Earth Modeling of Overhanging Cliffs, Extending 2.5-D Lidar Classifiers to Handle 3D Surface Classification Problems. ASPRS 2012 Annual Conference Proceedings. 
Pritchard, D., Anderson, J., Correll, C., Fogg, J., Gebhardt, K., Krapf, R., Leonard, S., Mitchell, B., Staats, J., 1998, Riparian Area Management: A User Guide to Assessing Proper Functioning Condition and the, Supporting Science for Lotic Areas: USDI Bureau of Land Management and USDA Forest Service and Natural Resources Conservation Service Technical Report 1737-15.

Samadi, A., Amiri-Tokaldany, E., Davoudi, M.H., \& Darby, S.E., 2013, Experimental and numerical investigation of the stability of overhanging riverbanks: Geomorphology, v. 184, p. 1-19, accessed May 09, 2019, at https://doi.org/10.1016/j. geomorph.2012.03.033.

Stock, G., 2012, Yosemite, CA: El Portal, Mariposa Grove, Yosemite Canyon \& Tuolumne Meadows Airborne Lidar Data, National Center for Airborne Laser Mapping (NCALM), distributed by OpenTopography, accessed January 19, 2017, at https://doi.org/10.5069/G9GQ6VP3.
Wheaton, J.M., Brasington, J., Darby, S.E., Sear, D.A., 2010, Accounting for uncertainty in DEMs from repeat topographic surveys - improved sediment budgets: Earth Surface Processes and Landforms, v. 35, no. 2, p. 136- 156, accessed May 09, 2019, at https://doi.org/10.1002/esp.1886.

Williams, R.D., Bangen, S., Gillies, E., Kramer, N., Moir, H., Wheaton, J., 2020, Let the river erode! Enabling lateral migration increases geomorphic unit diversity: Science of The Total Environment, v. 715, accessed May 09, 2019, at https:// doi.org/10.1016/j.scitotenv.2020.136817.

Yildiz, A., Graf, F., Rickli, C., Springman, S.M., 2018, Determination of the shearing behaviour of root-permeated soils with a large-scale direct shear apparatus. Catena, v. 166, p. 98-113. accessed May 09, 2019, at https://doi.org/10.1016/j. catena.2018.03.022.
Moffett Field Publishing Service Center, California

Manuscript approved March 26, 2021

Edited by Aditya Navale

Illustration support by JoJo Mangano

Layout and design by Cory Hurd 

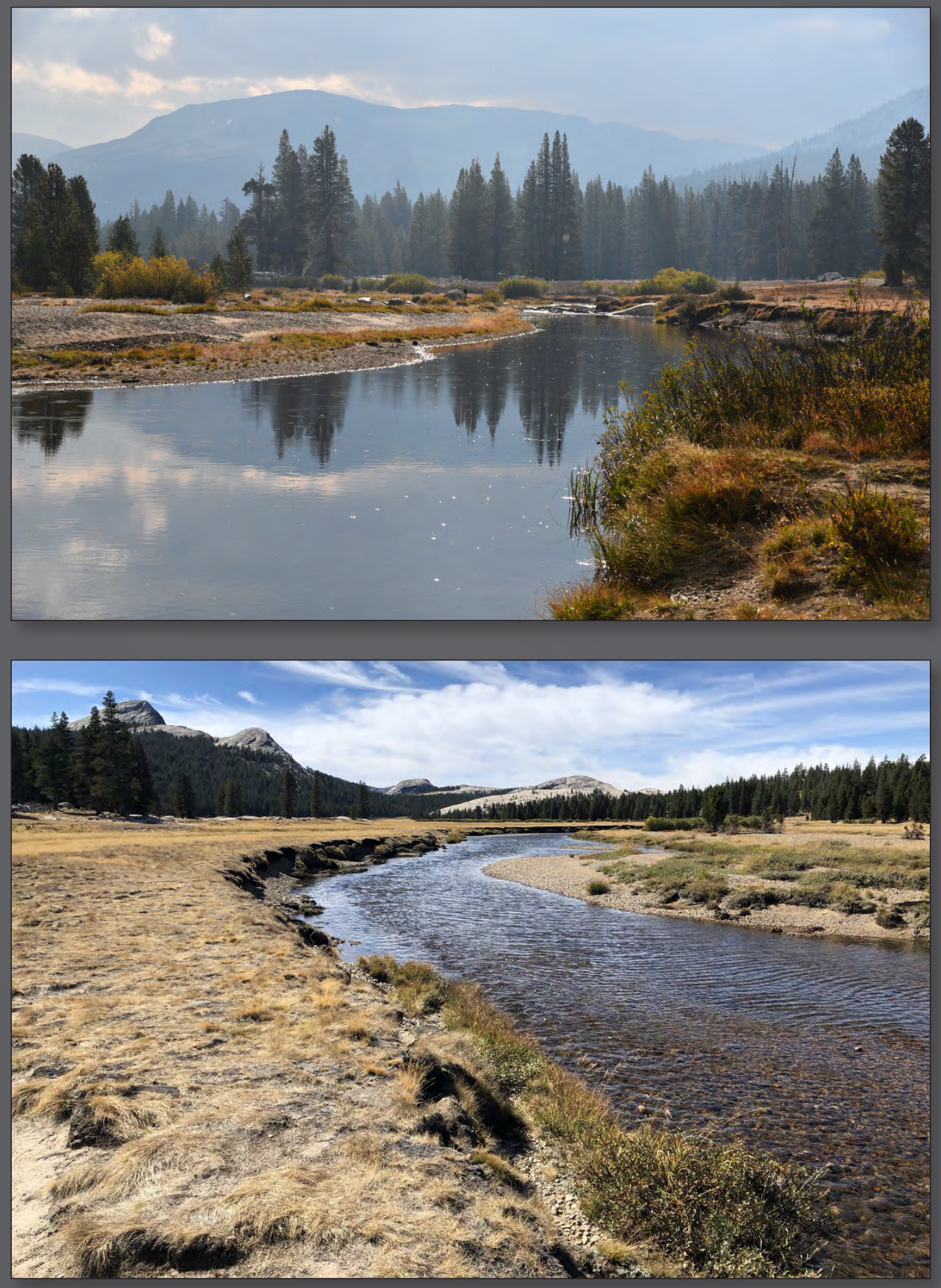